Prepared in cooperation with the Missouri Department of Conservation

\title{
Effects of Impoundments and Land-Cover Changes on Streamflows and Selected Fish Habitat in the Upper Osage River Basin, Missouri and Kansas
}

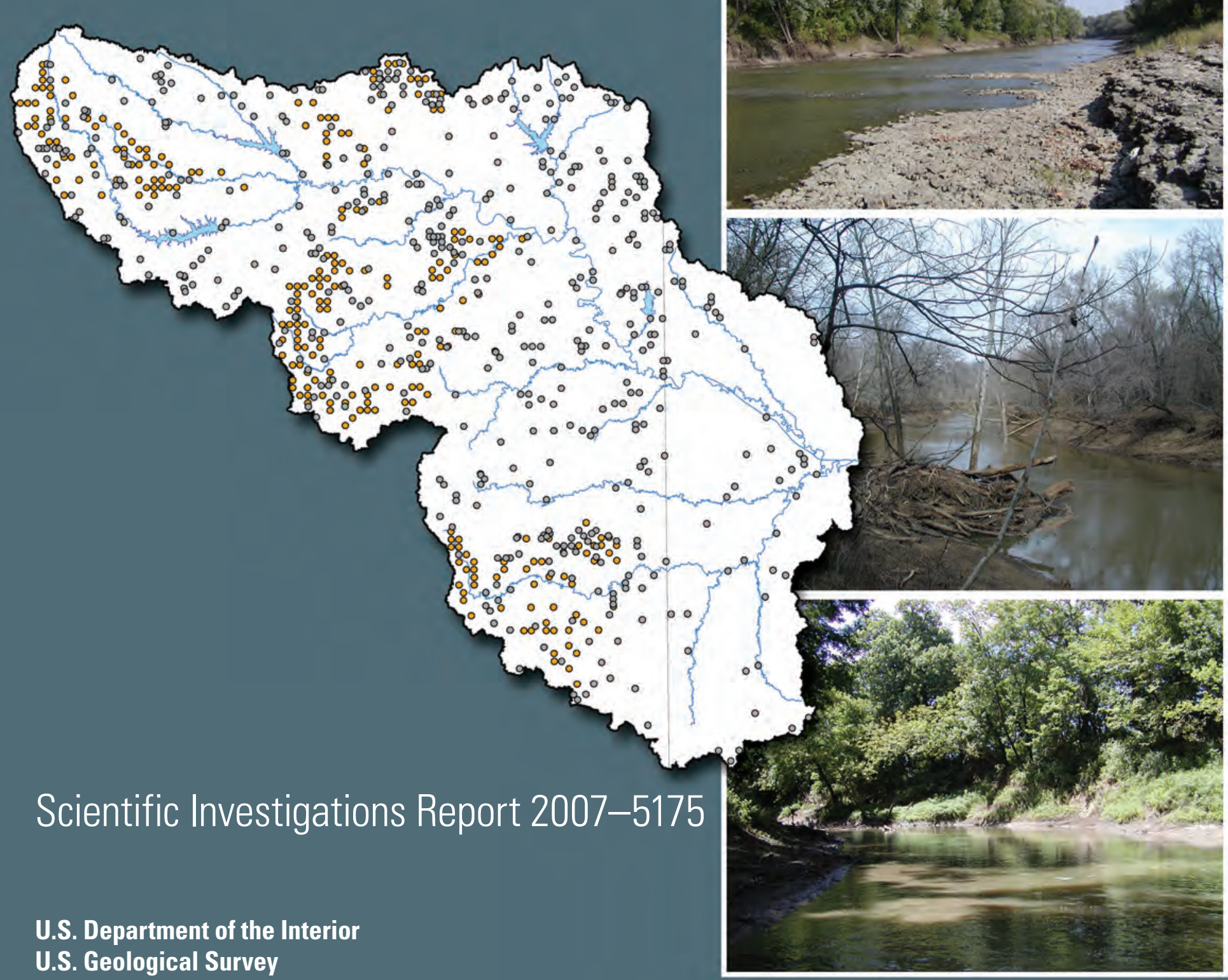


Cover Photographs. Marais des Cygnes River near the Missouri-Kansas state line, Missouri, July 2003 (top). Little Osage River near the junction with the Marmaton River, Missouri, February 2000 (middle). Marmaton River near the Missouri-Kansas state line, Missouri, September 2004 (bottom). Photographs by David C. Heimann, U.S. Geological Survey. 


\section{Effects of Impoundments and Land-Cover Changes on Streamflows and Selected Fish Habitat in the Upper Osage River Basin, Missouri and Kansas}

By David C. Heimann, Susan S. Licher, and Gregg K. Schalk

Prepared in cooperation with the Missouri Department of Conservation

Scientific Investigations Report 2007-5175 


\title{
U.S. Department of the Interior DIRK KEMPTHORNE, Secretary
}

\author{
U.S. Geological Survey \\ Mark D. Myers, Director
}

\section{U.S. Geological Survey, Reston, Virginia: 2007}

For product and ordering information:

World Wide Web: http://www.usgs.gov/pubprod

Telephone: 1-888-ASK-USGS

For more information on the USGS--the Federal source for science about the Earth, its natural and living resources, natural hazards, and the environment:

World Wide Web: http://www.usgs.gov

Telephone: 1-888-ASK-USGS

Any use of trade, product, or firm names is for descriptive purposes only and does not imply endorsement by the U.S. Government.

Although this report is in the public domain, permission must be secured from the individual copyright owners to reproduce any copyrighted materials contained within this report.

Suggested citation:

Heimann, D.C., Licher, S.S., and Schalk, G.K., 2007, Effects of impoundments and land-cover changes on streamflows and selected fish habitat in the upper Osage River Basin, Missouri and Kansas: U.S. Geological Survey Scientific Investigations Report 2007-5175, 96 p. plus CD. 


\section{Contents}

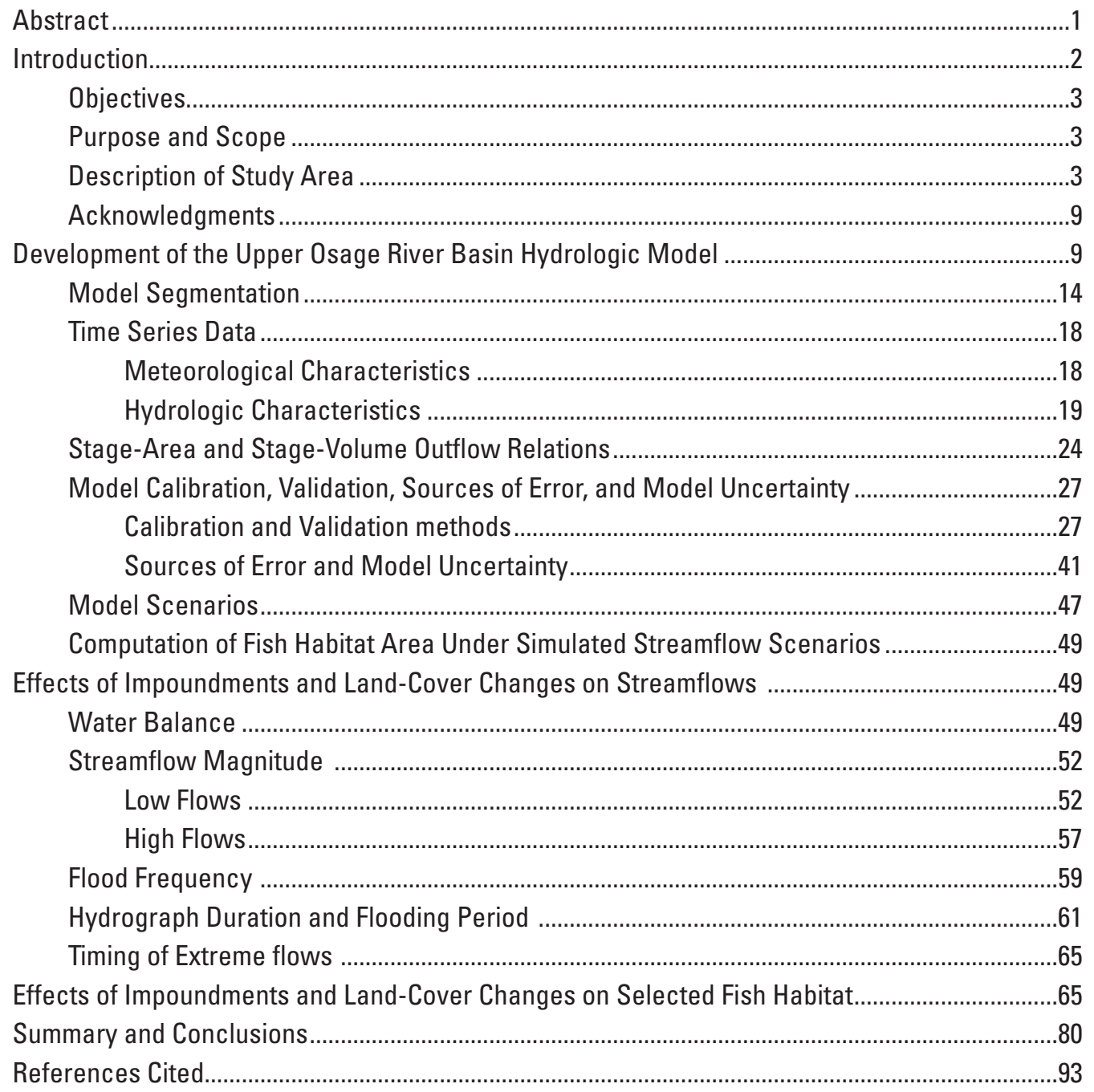

\section{Appendixes}

1-3. Hydrologic Simulation Program-FORTRAN user control input files for-

1. Marmaton River pre-settlement simulation scenario .............................................. CD

2. Marmaton River current condition simulation scenario ...........................................

3. Marmaton River proposed all impoundment simulation scenario .......................... CD

4. Comparison of the distribution of daily flows by scenario, and by month, for the Marais des Cygnes River near the Kansas-Missouri state line, Kansas, 1995-2004 .... CD

5. Comparison of the distribution of daily flows by scenario, and by month, for the Marmaton River near the Missouri-Kansas state line, Missouri, 1995-2004 . 


\section{Figures}

1. Map showing location of the upper Osage River Basin

2. Graphs showing comparisons of the $(A)$ annual precipitation distribution for 1949 through 2005 to the 1995 through 2004 study period, at Butler, Missouri, and Garnett, Kansas, and $(B) 1949$ through 2005 mean precipitation to the annual 1995 through 2004 precipitation at Butler, Missouri, and Garnett, Kansas.

3-8. Maps showing-

3. Existing and proposed impoundments in the upper Osage River Basin .7

4. Historical land cover in the upper Osage River Basin .8

5. Land cover in the upper Osage River Basin, 1995 ...............................................10

6. Hydrologic characteristics of soils in the upper Osage River Basin ........................11

7. Topographic characteristics of the upper Osage River Basin ................................12

8. Land-surface slope characteristics of the upper Osage River Basin .....................12

9. Schematic of pervious land hydrology module (PERLND) in the Hydrologic Simulation Program-FORTRAN.

10-16. Maps showing-

10. Upper Osage River basins for $(A)$ pre-settlement $(B)$ current, and (C) proposed simulation scenarios

11. Segmentation of the upper Marais des Cygnes River Basin .15

12. Segmentation of the lower Marais des Cygnes River Basin. 16

13. Segmentation of the Little Osage, Marmaton, and Osage River Basins 17

14. Distribution of primary precipitation stations used in the upper Osage River Basin

15. Distribution of temperature stations used in the upper Osage River Basin ............21

16. Location of reported point-source discharges and withdrawals in the upper Osage River Basin

17-24. Graphs showing-

17. Comparison of cumulative reported ground-water and surface-water withdrawals in the upper Osage River Basin, water years 1995 though $2004 \ldots \ldots . . .23$

18. Temporal distribution of point-source withdrawals and discharges in the Marais des Cygnes, Little Osage, and Marmaton River Basins, water years 1995 through 2004

19. Annual reported surface-water withdrawals, by basin and water-use category, water years 1995 through 2004

20. Existing and proposed impoundment detention volume and contributing drainage area for the Marais des Cygnes, Marmaton, and entire upper Osage River basins.

21. Comparison of simulated and observed daily streamflow at selected streamflow gaging locations in the upper Osage River Basin.

22. Streamflow-duration distributions for simulated and observed daily streamflows in the upper Osage River Basin

23. Comparison of streamflow hydrographs, by simulation scenario, at the Marmaton River near the Kansas-Missouri state line, Missouri (RCHRES 6), for November 19, 1994, through January 3, 1995.

24. (A) Total potential impoundment retention and detention volume and $(B)$ temporal variability in simulated impoundment storage in the Mamaton River Basin by simulation scenario 
25-39. Graphs showing-

25. Comparison of outlfows from a single Marmaton River impoundment by outlfow design and range of selected annual climatic conditions

26. Distribution of differences between monthly minimum 1-, 3-, 7-, and 30-day Prop-all50 adj and Observed streamflows, by selected months, for the Marais des Cygnes River near the Kansas-Missouri state line, Kansas (RCHRES 88), water years 1995 through 2004

27. Distribution of differences between monthly 1-, 3-, 7-, and 30-day minimum Prop-all50 adj ${ }_{\text {ad }}$ and Observed streamflows, by distribution of Observed flows, for the Marais des Cygnes River near the Kansas-Missouri state line, Kansas (RCHRES 88), water years 1995 through 2004

28. Distribution of differences between monthly minimum 1-, 3-, 7-, and 30-day Prop-all $50_{\text {adj }}$ and Observed streamflows, by year, for the Marais des Cygnes River near the Kansas-Missouri state line, Kansas (RCHRES 88), water years 1995 through 2004

29. Distribution of differences between monthly minimum 1-, 3-, 7-, and 30 -day Prop-all50 and Current simulated streamflows, by months, for the Marmaton River near the Kansas-Missouri state line, Missouri (RCHRES 6), water years 1995 through 2004

30. Distribution of differences between monthly minimum 1-, 3-, 7-, and 30 -day Prop-all50 and Current simulated streamflows, by distribution of Current simulated flows, for the Marmaton River near the Kansas-Missouri state line, Missouri (RCHRES 6), water years 1995 through 2004.

31. Distribution of differences between monthly minimum 1-, 3-, 7-, and 30 -day Prop-all50 and Current simulated streamflows, by year, for the Marmaton River near the Kansas-Missouri state line, Missouri (RCHRES 6), water years 1995 through 2004

32. Median difference in 1-day monthly maximum flows from Current or Observed monthly maximum flow, by model basin and scenario, water years 1995 through 2004

33. Differences in simulated flood frequency characteristics from Current simulated or Observed frequency, by model basin and scenario, water years 1995 through 2004

34. Differences in total large-flood hydrograph duration from Current simulated or Observed conditions, by model basin, reporting site, and simulation scenario, water years 1995 through 2004

35. Differences in simulated flooding duration characteristics from Current simulated or Observed conditions, by model basin and scenario, water years 1995 through 2004

36. Distribution of daily fish habitat for select categories at the Marais des

Cygnes River RCHRES 90, water years 1995 through 2004

37. Distribution of daily fish habitat for select categories at the Marais des Cygnes River RCHRES 93, water years 1995 through 2004

38. Distribution of daily fish habitat for select categories at the Marais des Cygnes River RCHRES 95, water years 1995 through 2004

39. Comparison of distributions of daily fish habitat for Observed and Prop-all50 ${ }_{\text {adj }}$ streamflow scenarios, by year and select species/life stage categories, at the Marais des Cygnes River RCHRES 90, water years 1995 through 2004 . 
40-47. Graphs showing-

40. Distribution of percent differences between Prop-all $50_{\text {adi }}$ and Observed fish habitat conditions for 1-, 7-, and 14-day maximum and minimum durations, by selected species/life stage categories, at the Marais des Cygnes River RCHRES 90, water years 1995 through 2004

41. Distribution of percent differences between Prop-all $50_{\text {adj }}$ and Observed fish habitat conditions for 1-, 7-, and 14-day maximum and minimum durations, by selected species/life stage categories, at the Marais des Cygnes River RCHRES 93, water years 1995 through 2004

42. Distribution of percent differences between Prop-all50 adj and Observed fish habitat conditions for 1-, 7-, and 14-day maximm and minimum durations, by selected species/life stage categories, at the Marais des Cygnes River RCHRES 95, water years 1995 through 2004

43. Distribution of daily fish habitat, by streamflow scenario and selected species/life stage categories, at the the Marmaton River near the KansasMissouri state line, Missouri (RCHRES 6), water years 1995 through 2004

44. Distribution of daily fish habitat, by streamflow scenario and selected species/life stage categories, at the Marmaton River RCHRES 11, water years 1995 through 2004

45. Comparison of distributions of daily fish habitat for Current simulated and Prop-all50 streamflow scenarios, by year and select species/life stage categories, at the Marmaton River near the Kansas-Missouri state line, Missouri (RCHRES 6), water years 1995 through 2004.

46. Distribution of percent differences between Prop-all50 and Current simulated fish habitat for 1-, 7-, and 14-day maximum and minimum durations, by selected species/life stage categories, at the Marmaton River near the Kansas-Missouri state line, Missouri (RCHRES 6), water years 1995 through 2004

47. Distribution of percent differences between Prop-all50 and Current simulated fish habitat for 1-, 7-, and 14-day maximum and minimum durations, by selected species/life stage categories, at the Marmaton River RCHRES 11, water years 1995 through 2004 


\section{Tables}

1. Current and proposed regulated drainage area by upper Osage River subbasin............6

2. Land-cover information by major sub-basin within the upper Osage River Basin............9

3. Characteristics of precipitation stations used in the upper Osage River Basin models CD

4. Characteristics of temperature stations used in the upper Osage River Basin models. CD

5. U.S. Geological Survey streamflow-gaging stations used in the development and calibration/validation of the upper Osage River Basin models.

6. Pipe flow outflow rates, in cubic feet per second, with varying pipe diameter and water depths

7. Correction factors for spillway culvert pipe lengths

8. Linear regression models used in estimating missing outflow design specifications for impoundments in the upper Osage River Basin

9. Relation between detention volume and median dam height used in estimating missing impoundment design specifications for the upper Osage River Basin models

10. Impoundment outflow characteristics used for estimating the elevation difference between primary and emergency spillway, primary spillway culvert diameter, and emergency spillway width in the in the 10-, 50-, and 90th-percentile design scenarios.

11. Criteria for determining Hydrologic Simulation Program-FORTRAN calibration and validation goodness of fit.

12. Summary statistics for the upper Osage River Basin model calibration and validation

13. Daily and monthly model fit statistics for the upper Osage River Basin calibration and validation sites

14. Parameters used in the upper Osage River Basin Hydrologic Simulation Program-FORTRAN models

15. Upper Osage River Basin model scenario characteristics ..............................................48

16. Model scenarios for reporting locations used in study ….............................................50

17. Selected fish habitat categories used in the determination of habitat area for Marais des Cygnes and Marmaton River study sites

18. Water balance summary information for hydrologic simulations of the Marmaton River Basin, water years 1995 through 2004

19 Streamflow summary statistics, by simulation scenario, for the Marais des Cygnes River near the Kansas-Missouri state line, Kansas (RCHRES 88), 1995 through 2004 water year

20. Streamflow summary statistics, by simulation scenario, for the Little Osage

River at Fulton, Kansas (RCHRES 25), 1995 through 2004 water years

21. Streamflow summary statistics, by simulation scenario, for the Marmaton River at RCHRES 54, 1995 through 2004 water years

22. Streamflow summary statistics, by simulation scenario, for the Marmaton River near Marmaton, Kansas (RCHRES 58), 1995 through 2004 water years

23. Streamflow summary statistics, by simulation scenario, for the Marmaton River near the Kansas-Missouri state line, Missouri (RCHRES 6), 1995 through 2004 water years. 
24. Differences between Observed and simulated streamflows for 1-, 3-, 7-, and 30-day monthly minimum flows at the Marais des Cygnes River near the Kansas-Missouri state line, Kansas, (RCHRES 88), 1995 through 2004 water years.

25. Differences between Observed and simulated streamflows for 1-, 3-, 7-, and 30-day monthly minimum flows at the Little Osage River near Fulton, Kansas (RCHRES 25), 1995 through 2004 water years.

26. Differences between Current simulated flows and those of pre-settlement and proposed scenarios for 1-, 3-, 7-, and 30-day monthly minimum flows at the Marmaton River, RCHRES 54, 1995 through 2004 water years

27. Differences between Current simulated flows and those of pre-settlement and proposed scenarios for 1-, 3-, 7-, and 30-day monthly minimum flows at the Marmaton River near Marmaton, Kansas (RCHRES 58), 1995 through 2004 water years.

28. Differences between Current simulated flows and those of pre-settlement and proposed scenarios for 1-, 3-, 7-, and 30-day monthly minimum flows at the Marmaton River near the Kansas-Missouri state line, Missouri (RCHRES 6), 1995 through 2004 water years

29. Summary statistics for simulated daily fish habitat area at the Marais des Cygnes River RCHRES 90, 1995 through 2004 water years CD

30. Summary statistics for simulated daily fish habitat area at the Marais des Cygnes River RCHRES 93, 1995 through 2004 water years.

31. Summary statistics for simulated daily fish habitat area at the Marais des Cygnes River RCHRES 95, 1995 through 2004 water years.

32. Summary statistics for simulated daily fish habitat area at the Marmaton River near the Kansas-Missouri state line, Missouri (RCHRES 6),1995 through 2004 water years

33. Summary statistics for simulated daily fish habitat area at the Marmaton River RCHRES 11, 1995 through 2004 water years 


\section{Conversion Factors}

\begin{tabular}{|c|c|c|}
\hline Multiply & By & To obtain \\
\hline \multicolumn{3}{|c|}{ Length } \\
\hline inch (in) & .3937 & centimeters $(\mathrm{cm})$ \\
\hline foot $(\mathrm{ft})$ & 0.3048 & meter $(\mathrm{m})$ \\
\hline mile (mi) & 1.609 & kilometer $(\mathrm{km})$ \\
\hline \multicolumn{3}{|c|}{ Area } \\
\hline acre & 4,047 & square meter $\left(\mathrm{m}^{2}\right)$ \\
\hline acre & 0.4047 & hectare (ha) \\
\hline acre & 0.004047 & square kilometer $\left(\mathrm{km}^{2}\right)$ \\
\hline square foot $\left(\mathrm{ft}^{2}\right)$ & 929.0 & square centimeter $\left(\mathrm{cm}^{2}\right)$ \\
\hline square foot $\left(\mathrm{ft}^{2}\right)$ & 0.09290 & square meter $\left(\mathrm{m}^{2}\right)$ \\
\hline square mile $\left(\mathrm{mi}^{2}\right)$ & 259.0 & hectare (ha) \\
\hline square mile $\left(\mathrm{mi}^{2}\right)$ & 2.590 & square kilometer $\left(\mathrm{km}^{2}\right)$ \\
\hline \multicolumn{3}{|c|}{ Volume } \\
\hline gallon (gal) & 3.785 & liter $(\mathrm{L})$ \\
\hline gallon (gal) & 0.003785 & cubic meter $\left(\mathrm{m}^{3}\right)$ \\
\hline million gallons (Mgal) & 3,785 & cubic meter $\left(\mathrm{m}^{3}\right)$ \\
\hline cubic foot $\left(\mathrm{ft}^{3}\right)$ & 28.32 & cubic decimeter $\left(\mathrm{dm}^{3}\right)$ \\
\hline cubic foot $\left(\mathrm{ft}^{3}\right)$ & 0.02832 & cubic meter $\left(\mathrm{m}^{3}\right)$ \\
\hline acre-foot (acre-ft) & 1,233 & cubic meter $\left(\mathrm{m}^{3}\right)$ \\
\hline acre-foot (acre-ft) & 0.001233 & cubic hectometer $\left(\mathrm{hm}^{3}\right)$ \\
\hline \multicolumn{3}{|c|}{ Flow rate } \\
\hline acre-foot per day (acre-ft/d) & 0.01427 & cubic meter per second $\left(\mathrm{m}^{3} / \mathrm{s}\right)$ \\
\hline acre-foot per year (acre-ft/yr) & 1,233 & cubic meter per year $\left(\mathrm{m}^{3} / \mathrm{yr}\right)$ \\
\hline cubic foot per second $\left(\mathrm{ft}^{3} / \mathrm{s}\right)$ & 0.02832 & cubic meter per second $\left(\mathrm{m}^{3} / \mathrm{s}\right)$ \\
\hline cubic foot per day $\left(\mathrm{ft}^{3} / \mathrm{d}\right)$ & 0.02832 & cubic meter per day $\left(\mathrm{m}^{3} / \mathrm{d}\right)$ \\
\hline gallon per day (gal/d) & 0.003785 & cubic meter per day $\left(\mathrm{m}^{3} / \mathrm{d}\right)$ \\
\hline million gallons per day (Mgal/d) & 0.04381 & cubic meter per second $\left(\mathrm{m}^{3} / \mathrm{s}\right)$ \\
\hline
\end{tabular}

Temperature in degrees Fahrenheit $\left({ }^{\circ} \mathrm{F}\right)$ may be converted to degrees Celsius $\left({ }^{\circ} \mathrm{C}\right)$ as follows:

$$
{ }^{\circ} \mathrm{C}=\left({ }^{\circ} \mathrm{F}-32\right) / 1.8
$$

Vertical coordinate information is referenced to the North American Vertical Datum of 1988 (NAVD 88).

Horizontal coordinate information is referenced to the North American Datum of 1983 (NAD 83). Water year is defined as 0ctober 1 through September 30. 


\title{
GLOSSARY OF ACRONYMS AND ABBREVIATIONS
}

\section{Hydrologic Simulation Program-FORTRAN parameters and terms (Bicknell and others, 2004)}

\author{
AGWETP - Fraction of evapotranspiration from active ground water \\ AGWRC-Base groundwater recession \\ BASETP - Fraction of evapotranspiration from baseflow \\ CEPSC - Interception storage capacity \\ DEEPFR - Fraction of groundwater inflow transferred to deep recharge \\ model RCHRES \\ IMPLND_Impervious land area \\ INFILT-Index to infiltration capacity \\ INTFW- Interflow inflow parameter \\ IRC-Interflow recession paramter \\ KVARY - Variable ground-water recession parameter \\ LSUR-Length of overland flow path \\ LZETP_Lower zone evapotranspiration parameter \\ LZSN_Lower zone nominal soil moisture storage \\ NSUR-Manning's n (roughness coefficient) for overland flow \\ PERLND-Pervious land area \\ RCHRES-HSPF stream channel reach or reservoir \\ SLSUR-Slope of overland flow plane \\ UZSN_Upper zone nominal soil moisture storage
}

FTABLES-Depth-area, depth-volume, and depth-outflow relation table developed for each

\section{Software programs used in development of hydrologic simulations}

BASINS - B Better assessment science integrating point and non-point sources; used in development of HSPF and stormwater assessment tool (SWAT) models (U.S. Environmental Protection Agency, 2005a).

CGAP-Channel geometry analysis program used to develop depth-area, depth-volume, and depth-outflow tables from stream channel information (U.S. Geological Survey, 2005d)

GenScn-Program used for the generation and analysis of model simulation scenarios (U.S. Geological Survey, 2005d).

GenFTABLE-Program used to convert CGAP output into FTABLES for use in HSPF (U.S. Geolgoical Survey, 2005d).

HSPF_-Hydrologic Simulation Program-FORTRAN (Bicknell and others, 2004).

HSPFEXP_Expert system for calibration of HSPF (U.S. Geological Survey, 2005d).

WdmUtil-Utility program used to import hydrologic and meteorologic time series data into watershed data management (wdm) file format (U.S. Environmental Protection Agency, 2005b).

WinHSPF-Microsoft Windows version of HSPF (packaged with BASINS and available at U.S. Environmental Protection Agency, 2005a). 


\section{Hydrologic Simulation Program-FORTRAN simulation scenarios developed in study}

Pre+infilt_-The simulated daily or hourly pre-settlement streamflow time series using an INFILT parameter double that used in the Current scenario.

Pre+infilt $_{\text {adj }}$ - The adjusted (based on the ratio of observed to simulated values) daily or hourly pre-settlement streamflow time series using an INFILT parameter double that used in the Current scenario.

Current—The simulated daily or hourly streamflow time series using 1995 land cover and existing (2005) impoundments.

Observed-The observed daily or hourly streamflow time series that is only available at those reporting locations corresponding to a U.S. Geological Survey streamflow gaging station.

Prop-sel50_-Simulated proposed streamflow time series using selected proposed impoundments and median values as estimates for any missing impoundment design criteria. Prop-sel10_-Simulated proposed streamflow time series using selected proposed impoundments and $10^{\text {th }}$-percentile values as estimates for any missing impoundment design criteria.

Prop-sel90_-Simulated proposed streamflow time series using selected proposed impoundments and $90^{\text {th }}$-percentile values as estimates for any missing impoundment design criteria.

Prop-sel50 adj -Adjusted (based on the ratio of observed to simulated values) proposed streamflow time series for selected proposed impoundments using median estimates for any missing impoundment design criteria.

Prop-sel10 ${ }_{\text {adj }}$ Adjusted (based on the ratio of observed to simulated values) proposed streamflow time series for selected proposed impoundments using $10^{\text {th }}$-percentile estimates for any missing impoundment design criteria.

Prop-sel90 ${ }_{\text {adj }}$-Adjusted (based on the ratio of observed to simulated values) proposed streamflow time series for selected proposed impoundments using $90^{\text {th }}$-percentile estimates for any missing impoundment design criteria.

Prop-all50-Simulated proposed streamflow time series using all proposed impoundments and median estimates for any missing impoundment design criteria.

Prop-all10 — Simulated proposed streamflow time series using all proposed impoundments and $10^{\text {th }}$-percentile estimates for any missing impoundment design criteria.

Prop-all90_-Simulated proposed streamflow time series using all proposed impoundments and $90^{\text {th }}$-percentile estimates for any missing impoundment design criteria.

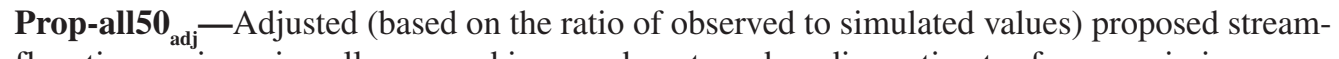
flow time series using all proposed impoundments and median estimates for any missing impoundment design criteria.

Prop-all10 ${ }_{\text {adj }}$-Adjusted (based on the ratio of observed to simulated values) proposed streamflow time series using all proposed impoundments and $10^{\text {th }}$-percentile values as estimates for any missing impoundment design criteria.

Prop-all90 ${ }_{\text {adj }}$-Adjusted (based on the ratio of observed to simulated values) proposed streamflow time series using all proposed impoundments and $90^{\text {th }}$-percentile values as estimates for any missing impoundment design criteria. 



\title{
Effects of Impoundments and Land-Cover Changes on Streamflows and Selected Fish Habitat in the Upper Osage River Basin, Missouri and Kansas
}

\author{
By David C. Heimann, Susan S. Licher, and Gregg K. Schalk
}

\section{Abstract}

A study was conducted by the U.S. Geological Survey in cooperation with the Missouri Department of Conservation to estimate the effects of existing and proposed impoundments, land-cover changes, and reported water uses on streamflows in the 5,410-square mile upper Osage River Basin. The hydrologic model Hydrologic Simulation ProgramFORTRAN (HSPF) was calibrated and validated to current (1995-2004 water years) regulation and water-use conditions, and scenarios were developed to evaluate differences for the same 10-years of record under pre-settlement, and proposed impoundment conditions. Analyses included quantification of changes in the magnitude, frequency, timing, and duration of streamflows under each simulation scenario. Streamflows from the simulations were used in conjunction with known streamflow-fish habitat relations to quantify effects of altered flows on fish-habitat area at selected Marais des Cygnes and Marmaton River locations.

The cumulative effects of impoundments and land-cover changes were determined to substantially alter streamflows in the upper Osage River Basin model simulations spanning pre-settlement to proposed future conditions. The degree of streamflow alteration varied between major subbasins. Streamflows in the Marais des Cygnes River Basin were altered between pre-settlement and current conditions, primarily by major impoundments, with smaller changes expected with proposed regulation. Streamflows in the Little Osage River Basin were relatively unchanged between pre-settlement and current conditions with land-cover changes (primarily the conversion of native prairies to cultivated land) affecting flows more than the few current impoundments in this basin. The current peak flows in the Marmaton River Basin generally were higher than pre-settlement or proposed scenario peak flows. Of the three major subbasins, the Marmaton River Basin is likely to be the most affected by proposed impoundments.

Declines in monthly minimum streamflows under a proposed impoundment scenario at the Marais des Cygnes River near the Kansas-Missouri state line, Kansas, were greatest for the lowest 10 percent of corresponding observed flows and during the driest years (2000, 2001 water years); that is, the greatest percent declines in flows under proposed conditions generally occurred during the lowest current/observed flow periods. In a small headwater basin in the Marmaton River Basin, simulated declines in minimum flows were small (generally less than 6 cubic feet per second and less than 1 cubic foot per second for 1- and 3-day scenarios), but resulted in 10 to 18 additional zero flow days for the 10-year simulation for the proposed scenarios relative to current simulated conditions. Reductions in minimum monthly flows as a result of additional impoundments generally were less than 5 cubic feet per second at the Marmaton River near Marmaton, Kansas, and resulted in 6 additional zero flow days. The greatest declines between proposed and current flows at the Marmaton River near the Kansas-Missouri state line, Missouri, generally occurred in the lower 50 percentile of the distribution of current simulated flows and during the drier simulation years (2001-2003). Proposed conditions resulted in declines in the 0-10 percentile flow values for the 1-, 3-, and 7-day durations. July, August, and October had the largest declines in proposed low flows relative to current simulated low flows for the 10-year simulation at this site.

The flood frequency for the Marais des Cygnes River near the Kansas-Missouri state line was unchanged between observed and proposed conditions for the 10-year simulation, but was 450 percent greater under the pre-settlement scenarios compared to observed conditions. Flood frequency generally was greatest for the current condition scenarios in the Marmaton River Basin and least for the proposed conditions, although the effects of regulation on flood frequency decreased downstream from the Kansas-Missouri state line with substantial streamflow contributions from less regulated tributaries. The flood frequencies of the proposed scenarios were 54 to 60 percent less than current conditions at the Marmaton River near the Kansas-Missouri state line, whereas at a downstream location the flood frequencies under proposed conditions were 39 to 45 percent less than current conditions.

Minimum annual 1-, 7-, or 14-day selected fish habitat availability under a proposed scenario declined at three Marais des Cygnes River reporting sites by more than 10 percent 
compared with observed conditions, for one or more years, for each of nine seasonal fish habitat categories. Declines in minimum habitat availability under proposed conditions were at or near 100 percent for one or more years for summer flathead catfish, fall flathead catfish, fall channel catfish, and fall stonecat habitat categories at one Marais des Cygnes River location, and for summer flathead catfish, summer channel catfish, and fall flathead catfish at another Marais des Cygnes River location. Declines in annual 1-, 7-, or 14-day minimum habitat also were greater than 10 percent for one or more years for all categories at both Marmaton River reporting locations except for spring paddlefish habitat, which generally remained unchanged between current and proposed scenarios at one location. Declines in 1-, 7-, or 14-day proposed minimum habitat availability were at or near 100 percent for one or more years for slenderhead darter, summer flathead catfish, fall channel catfish, and fall stonecat habitat categories at one Marmaton River location and for spring suckermouth minnow, spring slenderhead darter, summer channel catfish, summer stonecat, and fall flathead catfish habitat at another.

Simulations of the Marmaton River Basin (1995 through 2004) indicated that the effects of a conversion of cultivated row crops back to pre-settlement native prairie soils, simulated using an increase in the infiltration model parameter, accounted for a greater difference in total runoff between presettlement and current/proposed scenarios than other changes in land cover or from impoundments. The simulated increase in soil infiltration capacity under native prairie conditions also resulted in lower peak flows for the pre-settlement model scenario compared with the current or proposed scenarios. Evaporative water losses increased with the addition of impoundments, and while these increases did not have a substantial effect on the total runoff from the basin they could account for simulated declines in low flows. The greater detention associated with proposed impoundments resulted in longer hydrograph recessions and lowered peak flows; this varied with modifications in simulated impoundment design.

\section{Introduction}

Artificial impoundments (ponds, lakes, reservoirs) can alter natural stream channel and riparian habitats by changing the timing and quantities of streamflow, stream/ground-water interactions, trapping of sediment, and the hydroperiods of riparian wetlands. Impoundments increase the storage and surface area of water at a local scale, but this may result in a net loss of water at a larger basin scale through increased evaporative losses. Another ecological consequence of the increase in localized water storage, wetted area, and sediment trapping may be an alteration in the maintenance and function of downstream riparian habitat and wetlands. Smith and others (2002) determined the frequency distribution of impoundments in the conterminous United States to be dominated by water bodies in the small (less than 25 acres) size class. Although the regu- lated area and the detention capability of any small, individual, impoundment may be insignificant in comparison to larger water bodies, the sheer numbers of these features can result in substantial cumulative effects at a larger basin scale (Smith and others, 2002; Renwick and others, 2005).

The greatest concentration of impoundments in the conterminous United States is in agricultural areas, especially in the eastern part of the Great Plains (Smith and others, 2002) including the upper Osage River Basin in eastern Kansas and west-central Missouri. Flood-control and recreation impoundments are common features in this basin. These impoundments are designed and permitted individually; a single impoundment may have little effect on streamflows, but the cumulative effects of hundreds of current and proposed impoundments on the natural streamflow regime of this basin are unknown. Multiple watershed districts within the Marais des Cygnes, Little Osage, and Marmaton River Basin, which compose the upper Osage River Basin, have watershed plans that include the construction of an estimated 283 new impoundments (Kansas Water Office, 2004). These proposed impoundments, in conjunction with an estimated 539 existing permitted impoundments (U.S. Army Corps of Engineers, 2005; Joe File, Kansas Department of Agriculture, written commun., 2005) within multiple watershed Districts, and three large U.S. Army Corps of Engineers reservoirs, can further regulate flows in the basin. The proposed impoundments would range from 2 to 215 acres at the primary spillway water level, with most impoundments less than 30 acres.

Dry-weather flows in the upper Osage River Basin may be altered substantially by additional impoundments and changes in land cover. During runoff events following dry periods, when lake levels have decreased because of infiltration and evaporation, little runoff will reach the channel immediately downstream from the dam until the lake comes up to the spillway elevation. Streamflow demands for irrigation, wetland management, drinking-water supplies, and power generation have continued to increase, and these increases in river withdrawals and withdrawals from flood plain wells in Kansas and Missouri also are concerns for sustaining dry-weather flows in the upper Osage River Basin (Dent and others, 1997). Land-cover changes also may have affected dry-weather flows and the frequency of floods in the basin. Originally, more than 80 percent of the upper Osage River Basin was covered by tall grass prairie (Schroeder, 1983). Only a few small, scattered tracts of native prairie remain; most have been converted to agriculture. Fuentes and others (2004) determined soil hydraulic conductivities for cultivated lands to be about an order of magnitude less than those for native prairies in Washington State, and these differences persisted after 27 years of continuous no-till practices. Such alterations in soil hydraulic properties, when applied over extensive areas, also can alter the hydrologic characteristics of a basin.

The West Osage River Watershed Inventory and Management Plan (Dent and others, 1997) provides information about the current hydrology, land cover, water quality, aquatic habitat, and aquatic biota in the upper Osage River 
Basin. Although most wetlands (Dahl, 1990) and much of the bottomland forests (Nelson, 1985) of Missouri have been removed for agriculture, numerous remnant wetlands and tracts of bottomland timber remain in the upper Osage River Basin, particularly in the Marmaton River Basin. Many of these areas are in public land holdings (Dent and others, 1997). Because streams and channelized rivers are deeply incised and alluvial deposits underlying wetlands consist of fine-grained material of low permeability, ground water generally is not a substantial source of water to riparian wetlands in the basin. Consequently, riparian wetlands in the upper Osage River Basin are recharged primarily through floods and precipitation (Heimann and Mettler-Cherry, 2004).

Stream channel and riparian habitats may be affected by changes in the natural streamflow regime of the upper Osage River Basin. Naturally-variable flood flows create and maintain habitats that are essential to aquatic and riparian species (Poff and others, 1997). Channel-forming flows that create and shape stream habitats and affect channel stability typically are floods that have a recurrence interval of 1-2.5 years (Leopold, 1994). Changes in frequency and duration of larger floods could substantially affect the hydroperiod (period, timing, and amount of water retention) of numerous remnant and managed wetlands. Native riparian wetland communities evolved under pre-development hydroperiods; therefore, changes to the frequency and duration of wetland inundation may jeopardize the survival of native communities and ongoing efforts to restore native riparian vegetation. Alterations in the magnitude, timing, or flow duration also can limit the operation and maintenance of publicly and privately managed riparian wetlands.

In addition to the ecological concerns of altered flows in the upper Osage River Basin, low-flow depletions may have undesirable effects on drinking water supplies as surface water is the primary source of drinking water for residents of the basin. In Missouri alone more than 25,000 people use more than 2.5 million gallons per day (Mgal/day) from surfacewater sources (Missouri Department of Natural Resources, 2000) in the basin.

\section{Objectives}

A study was conducted by the U.S. Geological Survey (USGS) in cooperation with the Missouri Department of Conservation to estimate the effects of impoundments, landcover changes, and point-source withdrawals and discharges on streamflows in the upper Osage River Basin. More information was needed to better understand the specific effects of flow regulation on riverine habitats and the quantity and timing of water supplies to aid managers and policy makers in determining and maintaining appropriate streamflow regimes for the upper Osage River Basin. The specific objectives of the study are as follows:

1. Simulate and predict the effects of proposed impoundments on low-flow sustainability and the frequency and duration of flood events with calibrated and validated hydrologic models.

2. To the extent that land-cover and hydrologic characteristics of pre-settlement conditions were available, use the hydrologic models to qualitatively characterize the historical streamflow regime under which native plant and animal species adapted.

3. Utilize calibrated models to identify and evaluate selected water-management strategies that have the potential to minimize any adverse effects from upstream impoundments.

4. Determine the contributions and depletions of streamflow by municipal, industrial, recreational, and irrigation sources in the Marais des Cygnes, Little Osage, and Marmaton River Basins.

\section{Purpose and Scope}

The purpose of this report is to present the results of numerical hydrologic simulations developed to estimate the effects of impoundments, land-cover changes, and reported water uses on streamflows in the upper Osage River Basin. Hydrologic models were calibrated and validated to current (1995-2004 water years) regulation and water-use conditions. The models were then modified to simulate the relative differences in flow for the same period of climatological record for pre-settlement and proposed-regulation conditions. Simulated streamflow time series for pre-settlement, current, and proposed conditions were compared at selected locations on the Marais des Cygnes, Little Osage, and Marmaton Rivers, along with changes in streamflow as a result of differences in impoundment outflow design and reported point-source withdrawals and discharges. Analyses included quantification of changes in the magnitude, frequency, duration, and timing of streamflows for each scenario. Output from simulation scenarios were used in conjunction with known streamflow-fish habitat relations at select locations in the upper Osage River Basin to quantify the effects of altered flow on fish habitat.

\section{Description of Study Area}

The upper Osage River Basin encompasses 5,410 square miles $\left(\mathrm{mi}^{2}\right)$ upstream from the Osage River at Schell City, Missouri, which represents the downstream extent of the study area (fig. 1). The basin lies in the Osage Plains physiographic region (Nelson, 1985) of Missouri and Osage Cuestas physiographic region of Kansas (Kansas Geological Survey, 1997). About 4,050 $\mathrm{mi}^{2}$ of the basin lies in Kansas and 1,360 mi in Missouri, and includes all or part of 13 Kansas and 4 Missouri counties. The largest population centers include Nevada, Missouri (fig. 1; population 8,607); Fort Scott, Kansas (population 8,297); and Butler, Missouri (population 4,209; U.S. Census Bureau, 2006). 


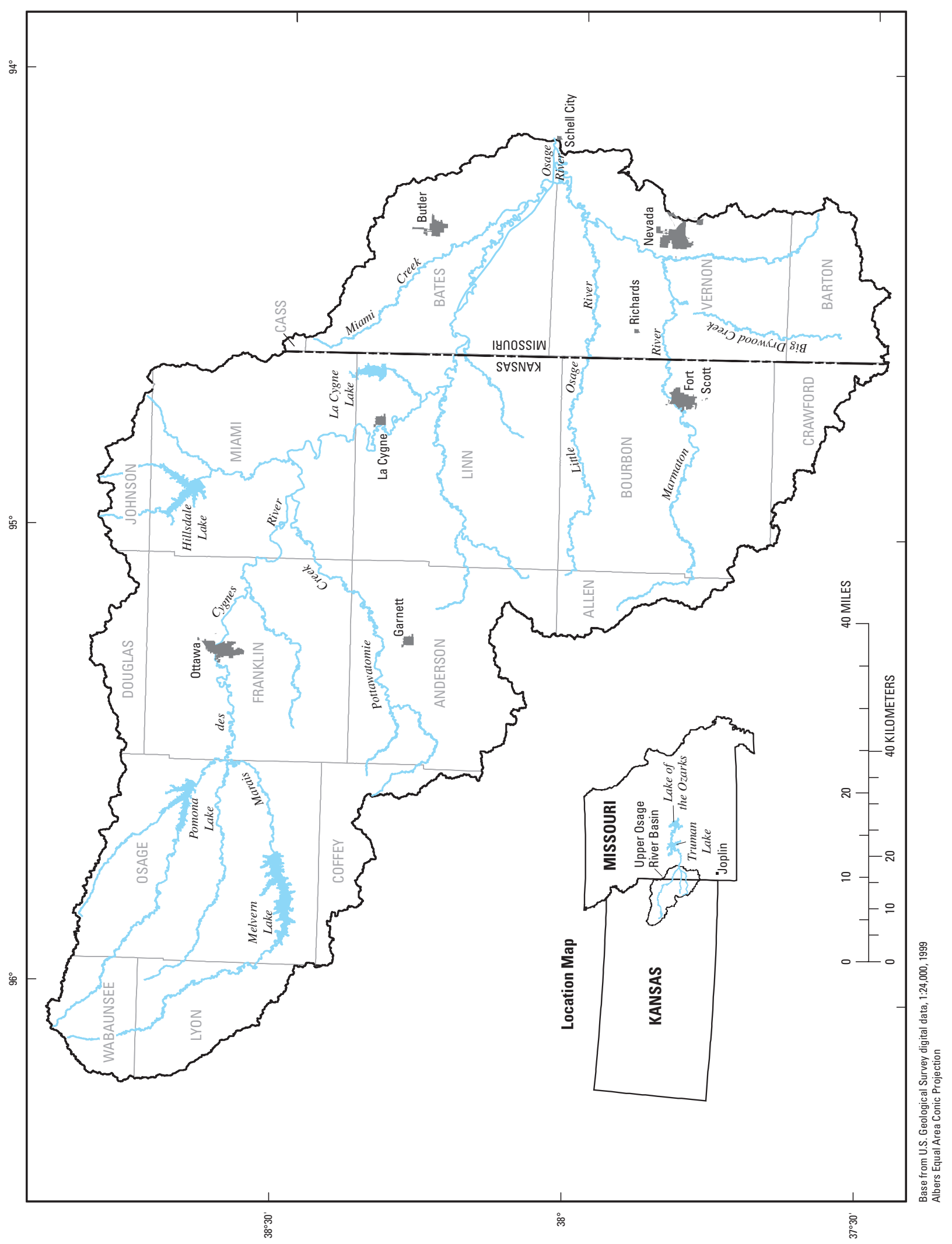

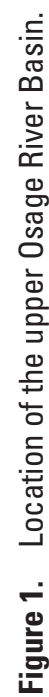


The 1949-2005 mean annual precipitation for the upper Osage River Basin was about 40 inches (in.); Butler, Missouri, (fig. 1) received an average of 40.2 in., and an average of 39.9 in. was received at Garnett, Kansas (fig. 1). June (5.38 in.) and May (4.90 in.) had the highest long-term average monthly rainfall at Butler, Missouri, and February (1.76 in.) had the lowest (High Plains Regional Climatic Center, 2007). The annual distribution of rainfall during the 10-year (1995 through 2004) study period fell within the central distribution of the 1949-2005 rainfall distribution at Butler, Missouri, whereas the 10-year distribution of precipitation at Garnett, Kansas, mirrored the 1949-2005 distribution at this site (fig. 2). The annual precipitation for the 10-years (1995 through 2004) of analysis at both locations included 4 years of above-average, 4 years of below-average, and 2 years of nearaverage precipitation (fig. 2).

The average annual 1949-2005 snowfall at Butler, Missouri, was 11.2 in. (equivalent to about 0.9 in. of rainfall). The 1949 through 2005 monthly mean temperatures at Butler, Missouri, ranged from $30.4^{\circ} \mathrm{F}$ in January to $79.0^{\circ} \mathrm{F}$ in July, with a mean annual temperature of $56.1^{\circ} \mathrm{F}$ (High Plains Regional Climatic Center, 2007).

The upper Osage River Basin is comprised of the Marais des Cygnes, Little Osage, and Marmaton River subbasins (fig.1), which originate in the Osage plains in Kansas and flow east into Missouri. The Marais des Cygnes River Basin has a drainage area of about 3,260 $\mathrm{mi}^{2}$ upstream from the MissouriKansas state line (table 1), and is the only Osage River tributary that is regulated by U.S. Army Corps of Engineers reservoirs (Pomona, Melvern, and Hillsdale Lakes; fig. 1). The 1959-2005 mean annual flow for the Marais des Cygnes River at the Kansas-Missouri state line was 2,180 cubic feet per second (ft $\left.\mathrm{ft}^{3} / \mathrm{s}\right)$ (U.S. Geological Survey, 2007). The current (2005) percentage of the area regulated in the Marais des Cygnes River Basin upstream from the Kansas-Missouri state line is about 34 percent, with about 27 percent attributable to the U.S. Army Corps of Engineers and LaCygne Lake impoundments, and the remainder attributable to smaller (each regulating less than $8 \mathrm{mi}^{2}$ ) impoundments (table 1). This value is expected to increase to about 42 percent with additional proposed impoundments, many of which are located in the Pottawatamie Creek Basin (fig. 3), and all of which are located in the upper one-half of the Marais des Cygnes River Basin. The Little Osage River has a drainage area of about $363 \mathrm{mi}^{2}$ upstream from the Kansas-Missouri state line, a 1949-2005 mean annual flow of $232 \mathrm{ft}^{3} / \mathrm{s}$ (U.S. Geological Survey, 2007), and is the least regulated tributary in the basin. Less than about 3 percent of the drainage area was regulated by impoundments in 2005, and no changes in the regulated area are proposed (table 1). The drainage area of the Marmaton River at the Kansas-Missouri state line is about $424 \mathrm{mi}^{2}$, and the current regulated area upstream from this point is about 25 percent.

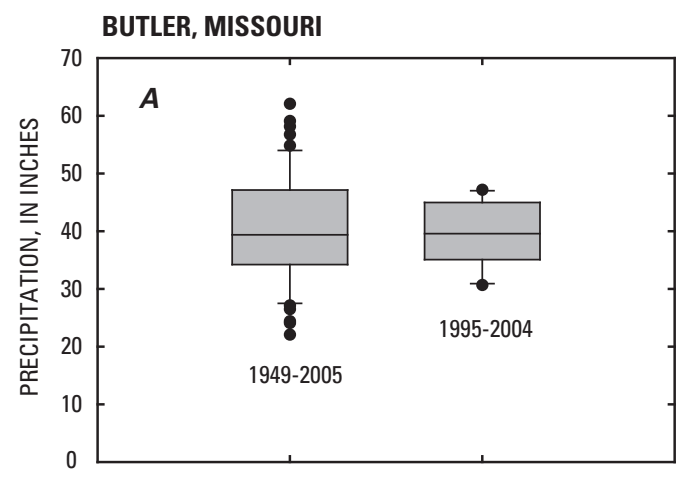

\section{GARNETT, KANSAS}
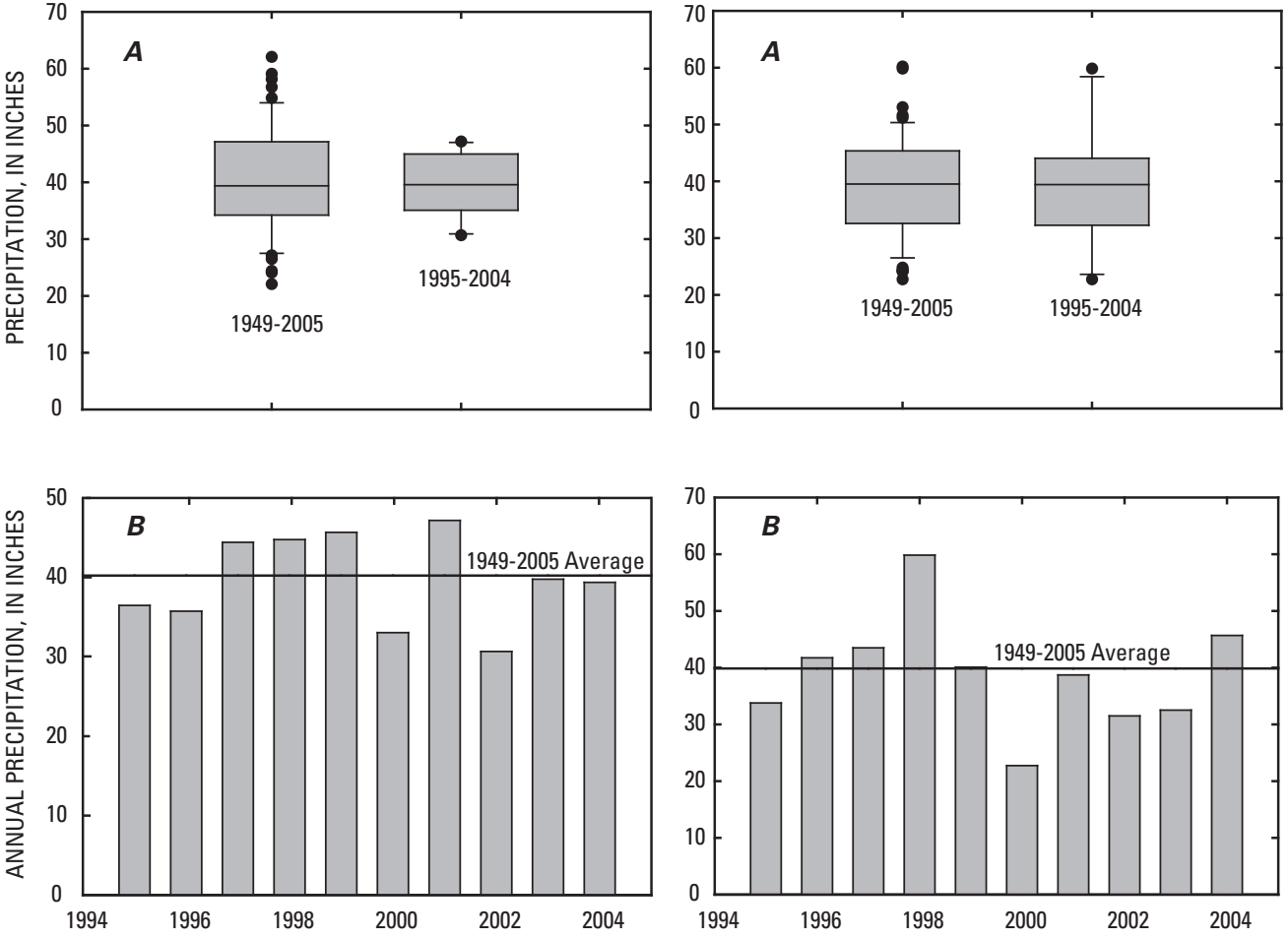

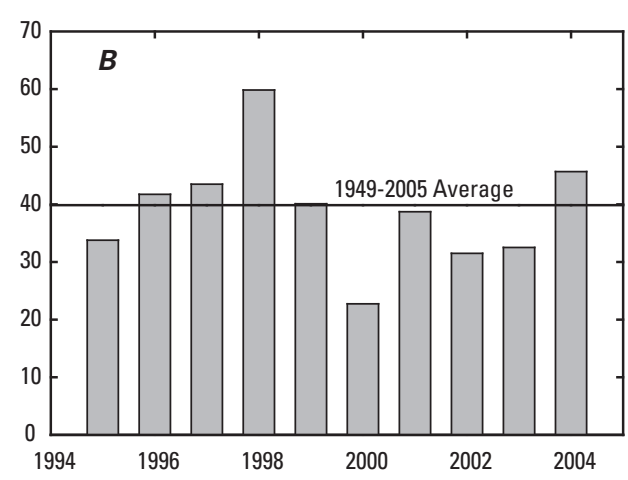

EXPLANATION

Percentile-Percentage of analyses equal to or less

than indicated values

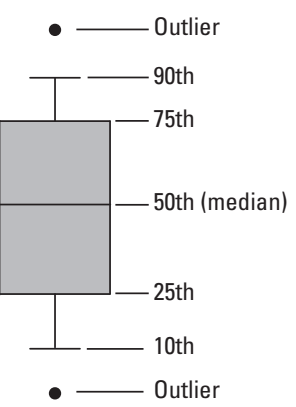

Figure 2. Comparisons of the $(A)$ annual precipitation distribution for 1949 through 2005 to the 1995 through 2004 study period, at Butler, Missouri, and Garnett, Kansas, and (B) 1949 through 2005 mean precipitation to the annual 1995 through 2004 precipitation at Butler, Missouri, and Garnett, Kansas. 
Table 1. Current and proposed regulated drainage area by upper Osage River subbasin.

\begin{tabular}{|c|c|c|c|c|c|c|c|}
\hline $\begin{array}{l}\text { Basin } \\
\text { (fig. 1) }\end{array}$ & $\begin{array}{c}\text { Total } \\
\text { drainage } \\
\text { area, } \\
\text { in square } \\
\text { miles }\end{array}$ & $\begin{array}{c}\text { Current } \\
\text { regulated } \\
\text { drainage area, } \\
\text { in square } \\
\text { miles }^{\mathrm{a}}\end{array}$ & $\begin{array}{c}\text { Additional } \\
\text { proposed } \\
\text { regulated } \\
\text { drainage area, } \\
\text { in square mile }\end{array}$ & $\begin{array}{l}\text { Cumulative } \\
\text { total proposed } \\
\text { regulated } \\
\text { drainage area, } \\
\text { in square } \\
\text { miles }\end{array}$ & $\begin{array}{c}\text { Current } \\
\text { regulated } \\
\text { drainage area, } \\
\text { in percent }\end{array}$ & $\begin{array}{l}\text { Additional } \\
\text { proposed } \\
\text { regulated } \\
\text { drainage area, } \\
\text { in percent }\end{array}$ & $\begin{array}{c}\text { Total } \\
\text { proposed } \\
\text { regulated } \\
\text { drainage } \\
\text { area, in } \\
\text { percent }\end{array}$ \\
\hline $\begin{array}{l}\text { Marais des Cygnes River } \\
\text { at Kansas-Missouri State } \\
\text { Line }\end{array}$ & 3,260 & $1,107(873)$ & 250 & 1,357 & $34.0(26.8)$ & 7.70 & 41.6 \\
\hline $\begin{array}{l}\text { Marais des Cygnes River } \\
\text { Basin }\end{array}$ & 3,790 & $1,175(873)$ & 250 & 1,366 & $29.5(23.0)$ & 6.60 & 36.1 \\
\hline $\begin{array}{l}\text { Little Osage River at } \\
\text { Kansas-Missouri State } \\
\text { Line }\end{array}$ & 363 & 11.1 & 0 & 11.1 & 3.10 & 0 & 3.10 \\
\hline $\begin{array}{l}\text { Little Osage River Basin } \\
\quad \text { (upstream of confluence } \\
\text { with Marmaton River) }\end{array}$ & 502 & 13.5 & 0 & 13.5 & 2.70 & 0 & 2.70 \\
\hline $\begin{array}{l}\text { Marmaton River at Kansas- } \\
\text { Missouri State Line }\end{array}$ & 424 & 106 & 186 & 292 & 25.1 & 41.7 & 66.8 \\
\hline Marmaton River Basin & 1,150 & 134 & 186 & 320 & 11.7 & 16.2 & 27.9 \\
\hline $\begin{array}{l}\text { Osage River near Schell } \\
\text { City, Missouri }\end{array}$ & 5,410 & 1,264 & 436 & 1,700 & 23.3 & 8.10 & 31.4 \\
\hline
\end{tabular}

${ }^{a}$ Values in parenthesis represent only Pomona, Melvern, Hillsdale, and LaCygne Lakes (see figure 1 for locations).

'Proposed drainage area determined from data provided by the Kansas Department of Agriculture, Division of Water Resources.

This value is expected to increase to about 67 percent (table 1) if all proposed impoundments are completed. The Marmaton River near Marmaton, Kansas (drainage area of $295 \mathrm{mi}^{2}$ ), had a 1972-2005 mean annual flow of $284 \mathrm{ft}^{3} / \mathrm{s}$ (U.S. Geological Survey, 2007).

Historically, the Osage River Basin was dominated by tall grass prairies with narrow oak-hickory forests along stream channels (fig. 4; Schroeder, 1983). Settlement of the basin in Missouri primarily began in the 1830's, after statehood, along primary transportation routes in the basin including the Osage, Marais des Cygnes, and Marmaton Rivers (McDermott, 1940; U.S. Department of Agriculture, 1970). The population of the basin declined during the civil war but recovered between 1866 and 1885 with the introduction of the railroad and the discovery of coal in the region. The population in Missouri counties of the basin steadily declined from the early 1900's through the 1960's, but has since remained steady with a shift from rural to urban population centers (U.S. Department of Agriculture, 1970; Hall and Orazem, 2005). With the advent of the steel plow and the quelling of wildfires, most of the native tallgrass prairies in the basin have been replaced by agricultural land covers. The historical land cover of the basin is represented in vegetation maps of Kansas (Küchler, 1974) and Missouri (Schroeder, 1983). Major land-cover types identified included prairie, and forests (table 2, fig. 4). Although not specified on the Küchler map, there also was a substantial amount of wetlands in the basin. Wetlands in the basin have been reduced through channelization, levees, and conversion to agriculture (Dent and others, 1997). The 1995 wetland landcover information was used as an estimate for the historical wetland area for this study. The lower 44 miles of the Marais des Cygnes River was channelized in the early 1900's to decrease flooding and increase agricultural land area, resulting in the loss of about $10 \mathrm{mi}$ of the original stream channel (Dent and others, 1997).

Land-cover information for the upper Osage River Basin was derived from the National Land Cover Database (USGS, 2005a) and based on 30-meter satellite thematic mapper data from 1992-1995. The 1995 land cover in the basin primarily was row crops (soybeans, wheat, corn, sorghum) and coolseason pasture (fig. 5; table 2). The trend in agricultural land cover in the Marmaton River Basin has been a shift from row crops to pasture (Bill Schoenberger, U.S. Department of Agriculture, Natural Resource Conservation Service, oral commun., 2005). The basin retains oak-hickory forests primarily along stream and river channels. Despite initial forest losses as a result of settlement, there was an 11 percent increase in forested area in the basin between 1959 and 1989 (Hahn and Spencer, 1991) because of wildfire suppression. The Marmaton River is considered one of the highest quality remaining prairie streams in Missouri, and its riparian corridor contains numerous remnant forested and constructed wetlands managed by public and private entities (Dent and others, 1997).

Surface bedrock in the upper Osage River Basin consists primarily of Pennsylvanian shales and sandstones with smaller 


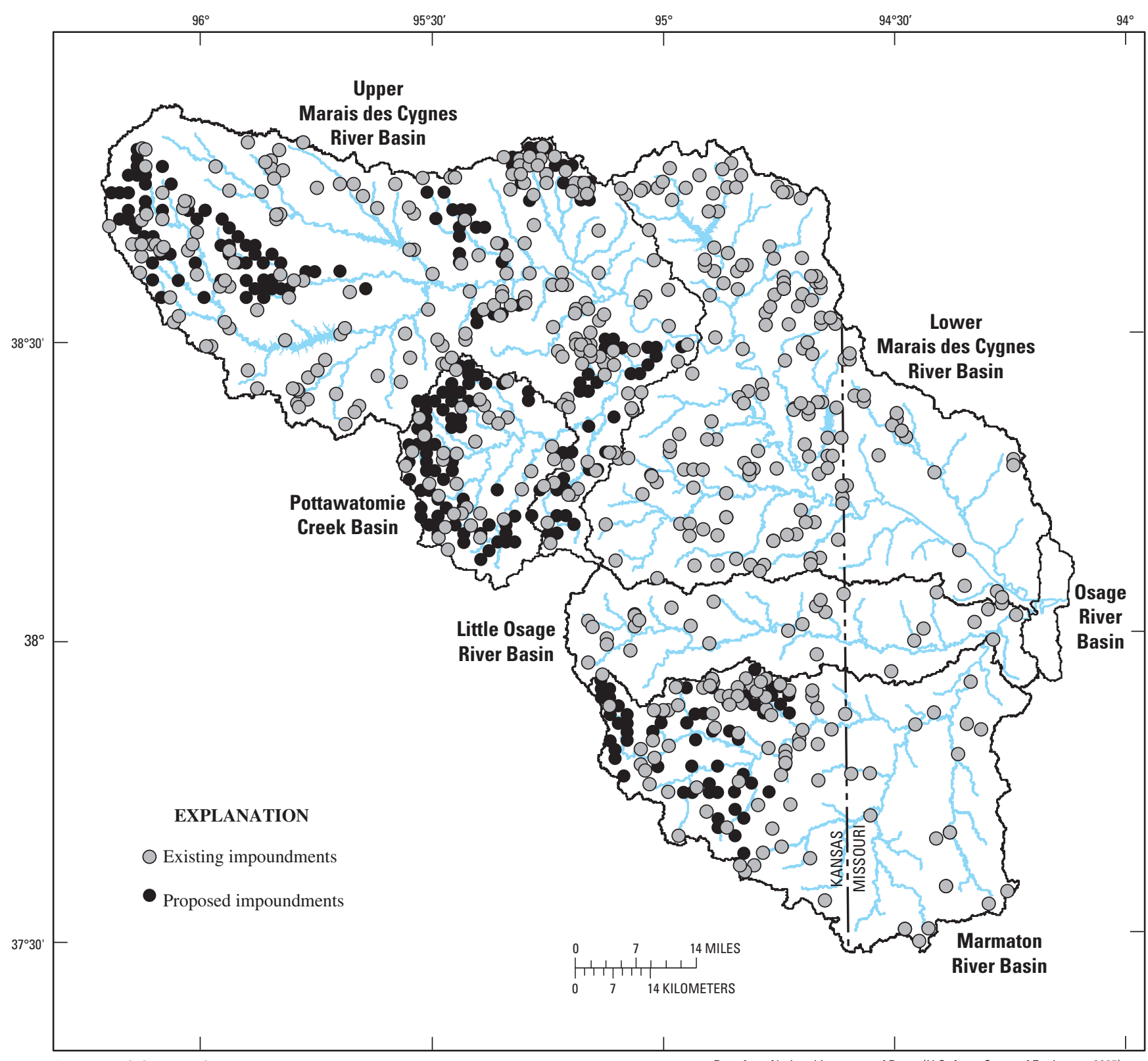

Base from U.S. Geological Survey digital data, 1:24,000, 1999

Data from National Inventory of Dams (U.S. Army Corps of Engineers, 2005) Albers Equal Area Conic Projection

Figure 3. Existing and proposed impoundments in the upper Osage River Basin.

amounts of limestone and coal (Bevans and others, 1984). These geologic strata are of low permeability; consequently, streamflows are sustained primarily by surface runoff. Baseflows are not well sustained in the basin (Skelton, 1976), and ground-water usage is limited (Bevans and others, 1984).

The upper Osage River Basin is located in the Cherokee Prairies Major Land Resource Area (U.S. Department of Agriculture, 1981) and soils mostly are Aqualfs and Udolls that are shallow to deep, medium textured, and poorly to well drained. The geologic parent material is shale, sandstone, and limestone on gently sloping uplands. Soils developed from limestone and sandstone tend to be loamy and shallow on ridges, whereas soils developed from shale usually are deep, claypan soils. Four major soil hydrologic groups are specified in the STATSGO data base (U.S. Department of Agriculture, 1991) including high infiltration rates (class A)—soils are deep, well drained to excessively drained sands and gravels; moderate infiltration rates (class B) - soils are deep and moderately deep, moderately well and well drained with moderately coarse textures; slow infiltration rates (class C) - soils with layers impeding downward movement of water or soils with moderately fine or fine textures; very slow infiltration rates (class D) - soils are clayey, have a high water table, or are shallow with an impervious layer. The upper Osage River 


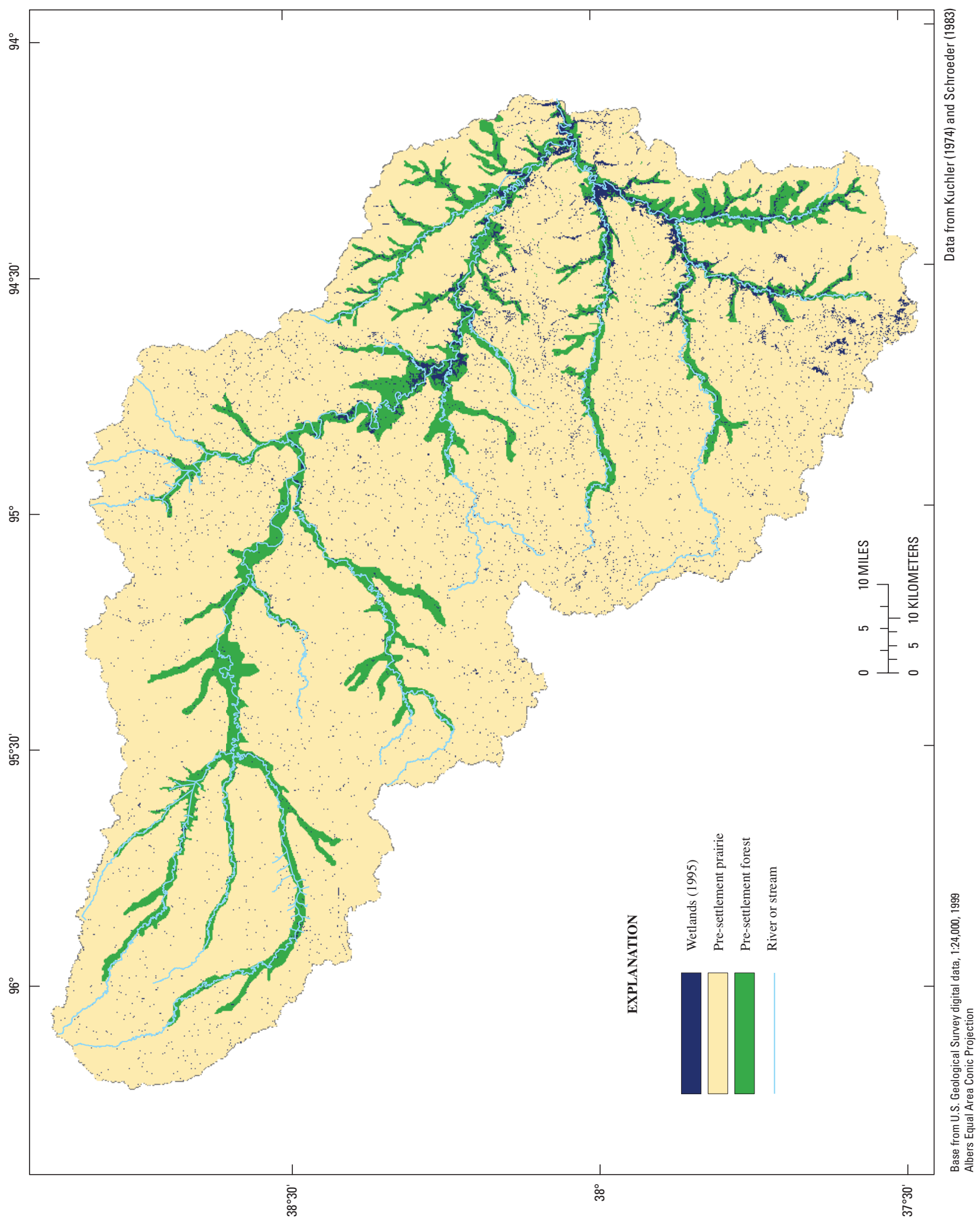

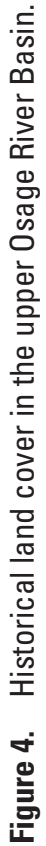




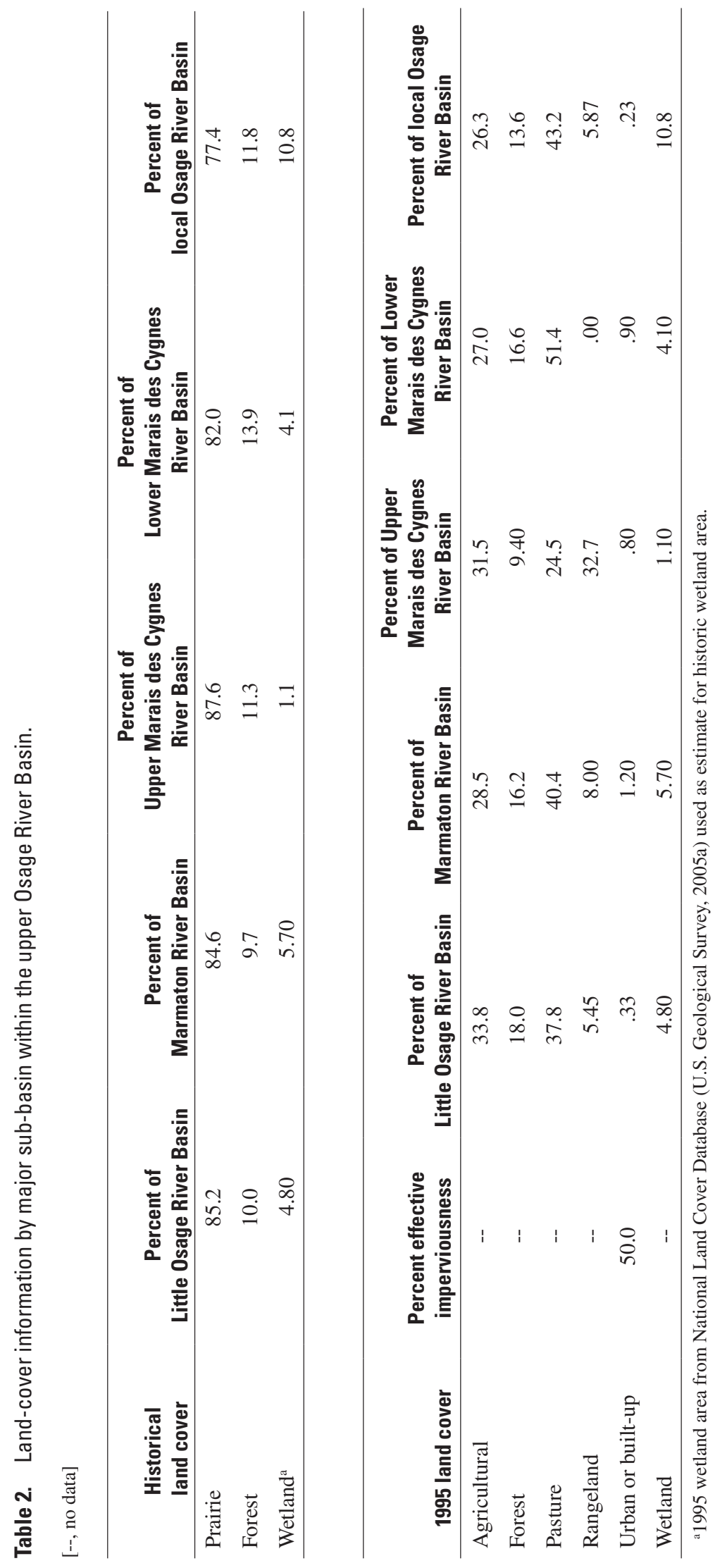

Basin primarily consists of class $\mathrm{C}$ soil types with some class D soils in valley deposits, and class B soils on uplands (fig. 6). The spatial distribution of the soil hydrologic classes was used to distribute infiltration and soil storage parameters in the hydrologic models.

The land surface in the upper Osage River Basin is rolling plains (Bevans and others, 1984) with 900 feet (ft) of relief, ranging from about $710 \mathrm{ft}$ near Schell City, Missouri, to a maximum of about $1,600 \mathrm{ft}$ in the western headwaters of the Marais des Cygnes River Basin (fig. 7). The upper Osage Basin is characterized by gentle slopes with most of the basin having slopes less than 3 percent (fig. 8). The subbasins composing the upper Osage Basin lie primarily in a westeast orientation.

\section{Acknowledgments}

The authors acknowledge support provided by the Missouri Department of Conservation and technical assistance and guidance provided by Jason Persinger, Del Lobb, Bill Turner, and Ron Dent of the Missouri Department of Conservation. Technical assistance with the Hydrologic Simulation Program-FORTRAN was provided by Paul Duda and Paul Hummel with Aqua Terra Consultants. The authors acknowledge the assistance in summarizing and generating tables and figures provided Bruce Perkins (U.S. Environmental Protection Agency; USGS Volunteer for Science).

\section{Development of the Upper Osage River Basin Hydrologic Model}

The Hydrologic Simulation ProgramFORTRAN (HSPF Version 12; Bicknell and others, 2004) was used to simulate hydrologic relations and streamflows at selected locations in the upper Osage River Basin under varying land cover and regulation scenarios. HSPF has been used to simulate hydrologic processes in a variety of geographic locations, spatial scales, and for a number of hydrologic applications (Duncker and others, 1995; Duncker and Melching, 1998; Jones and Winterstein, 2000; Zarriello and Sherwood, 1993; Zarriello, 1996; Coon and Johnson, 2005; Zarriello and Ries, 2000; Zarriello and Bent, 2004; Berris and others, 2001; Dinocola, 1990; Dinocola, 2001). HSPF is supported by the USGS 


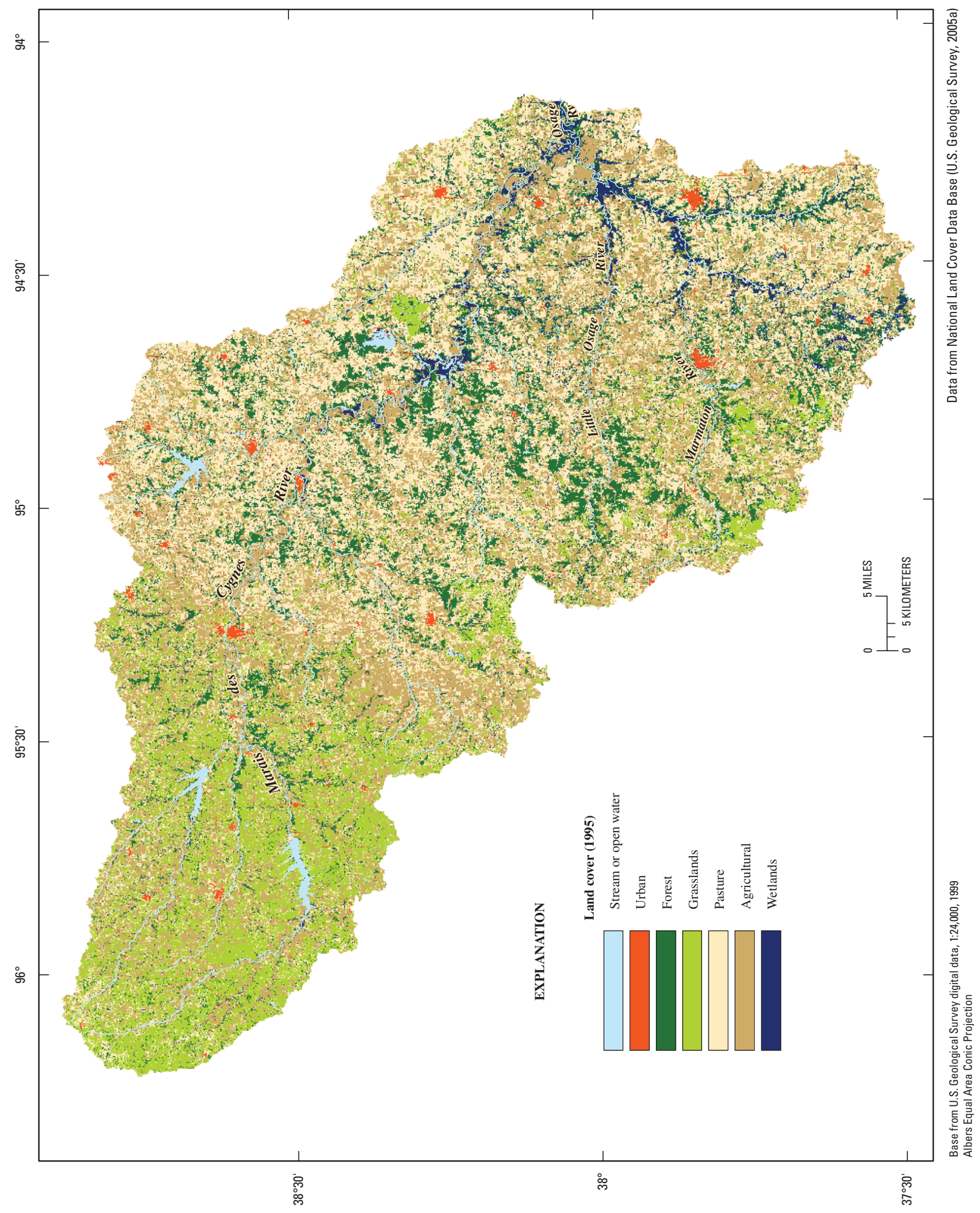

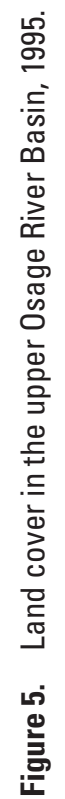




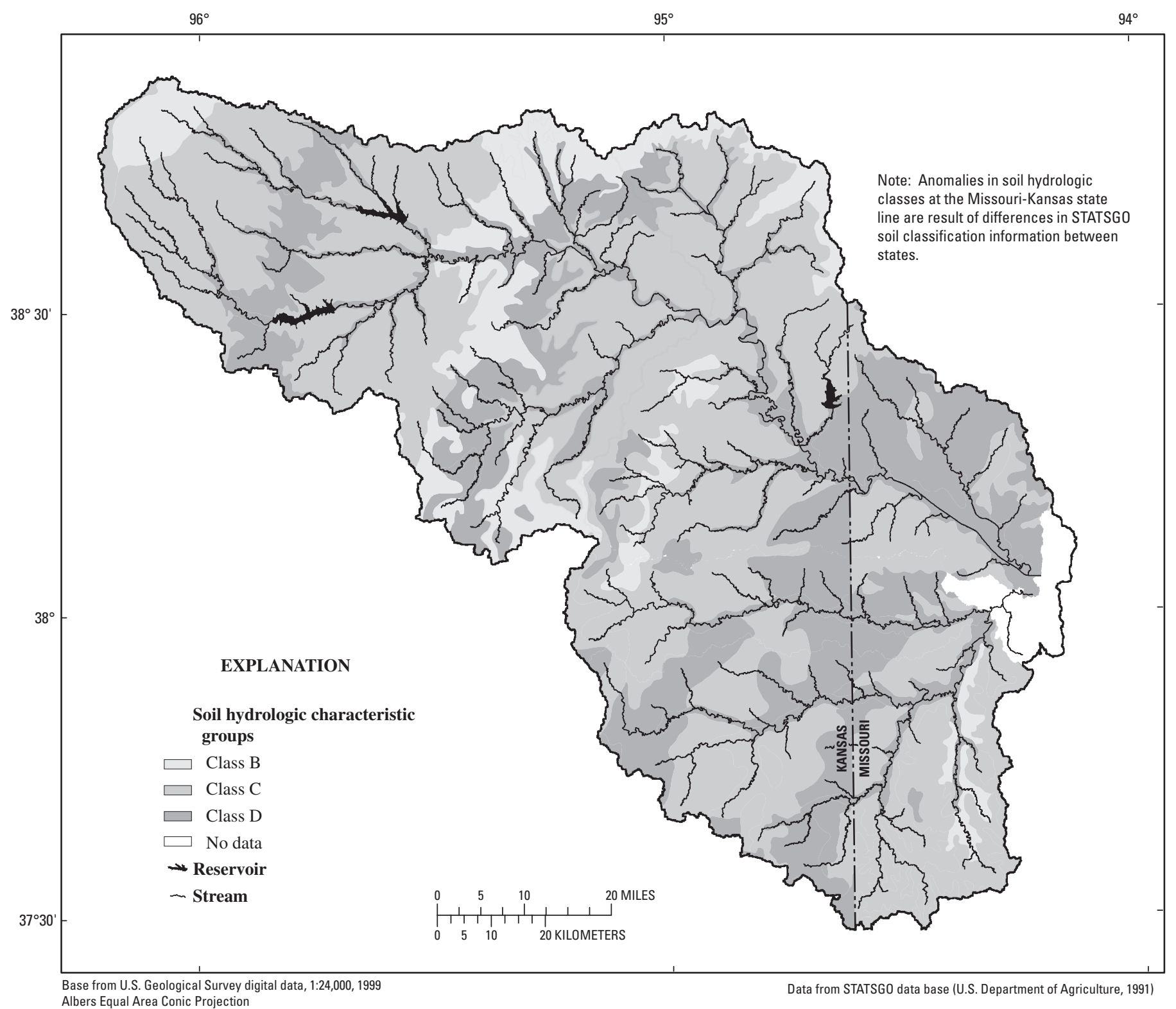

Figure 6. Hydrologic characteristics of soils in the upper Osage River Basin.

and Environmental Protection Agency (USEPA) and can be used for continuous simulations of natural and developed basins, including water management systems. It is a conceptual model using numerous mathematical modules capable of simulating surface runoff, subsurface flow, stream/lake hydraulics, and water-quality processes (Donigian and Imhoff, 2006). HSPF simulates the hydrologic processes utilizing a "lumped" parameter approach in that the spatial characteristics of land cover are not explicitly described within the primary model areas, and the hydrologic response of the system is described by adjustable (fitted) parameters. While lumped parameters may be used to define the hydrologic response from a land surface, HSPF is capable of simulating point-source withdrawals, discharges, and impoundment operations.
The upper Osage River Basin was segmented within HSPF into smaller land areas of similar hydrologic response (topography, land cover, and soil characteristics). Hydrologic processes for these land areas are simulated within the HSPF model through pervious (PERLND) and impervious (IMPLND) modules. As impervious area was minimal in the upper Osage River Basin, the PERLND module (fig. 9) was the dominant controlling module for this application. Each PERLND area unit was represented by three (prairie/rangeland, forest, and wetland for pre-settlement conditions) or six (urban, forest, grassland, pasture, agriculture, and wetland for current and proposed conditions) land-cover categories and the total relative areas associated with each of these land-cover categories are listed in table 2. The parameters used in defin- 


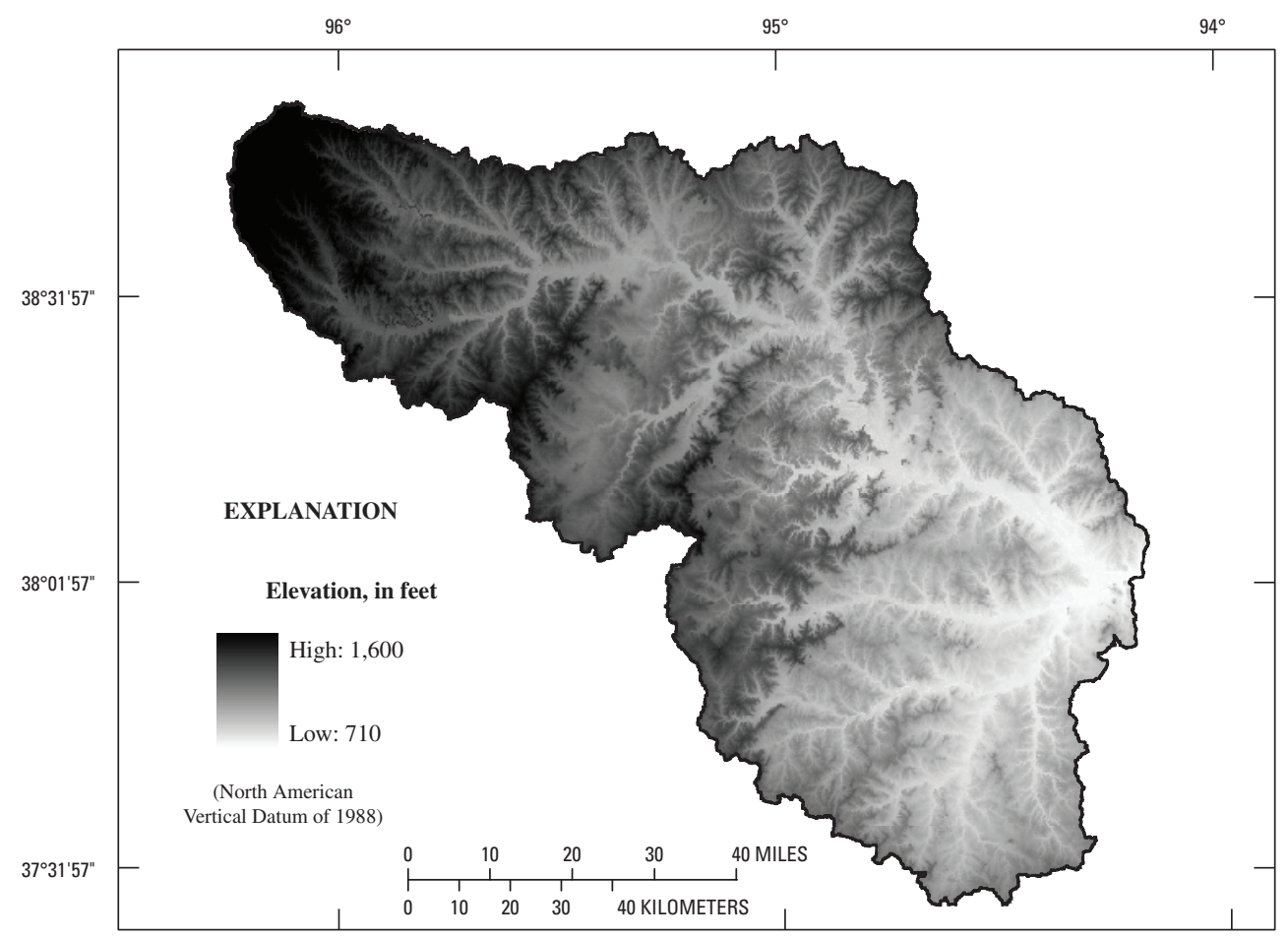

Base from U.S. Geological Survey digital data, 1:24,000, 1999 Albers Equal Area Conic Projection

Figure 7. Topographic characteristics of the upper Osage River Basin.

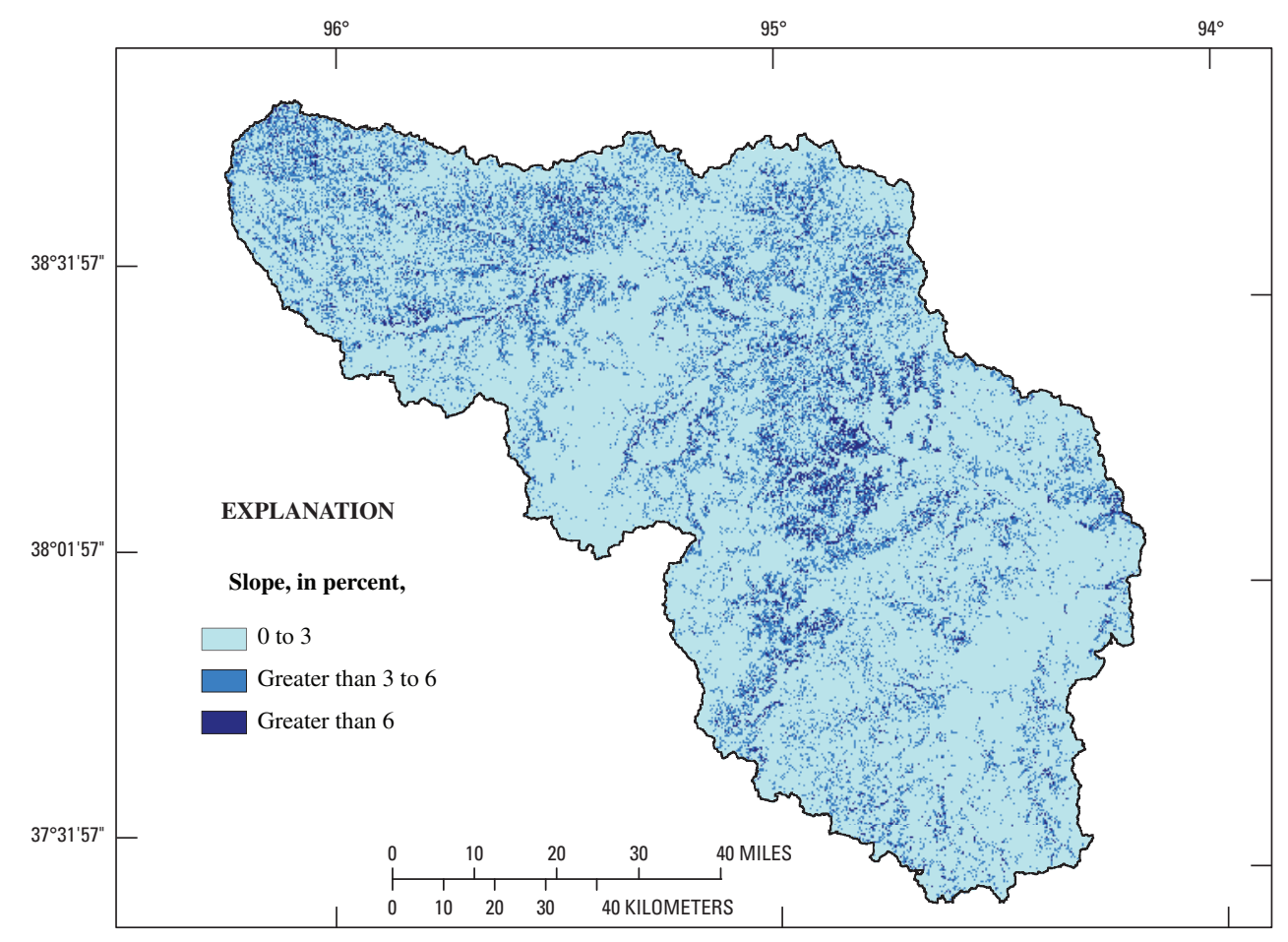

Base from U.S. Geological Survey digital data, 1:24,000, 1999 Albers Equal Area Conic Projection

Figure 8. Land-surface slope characteristics of the upper Osage River Basin. 


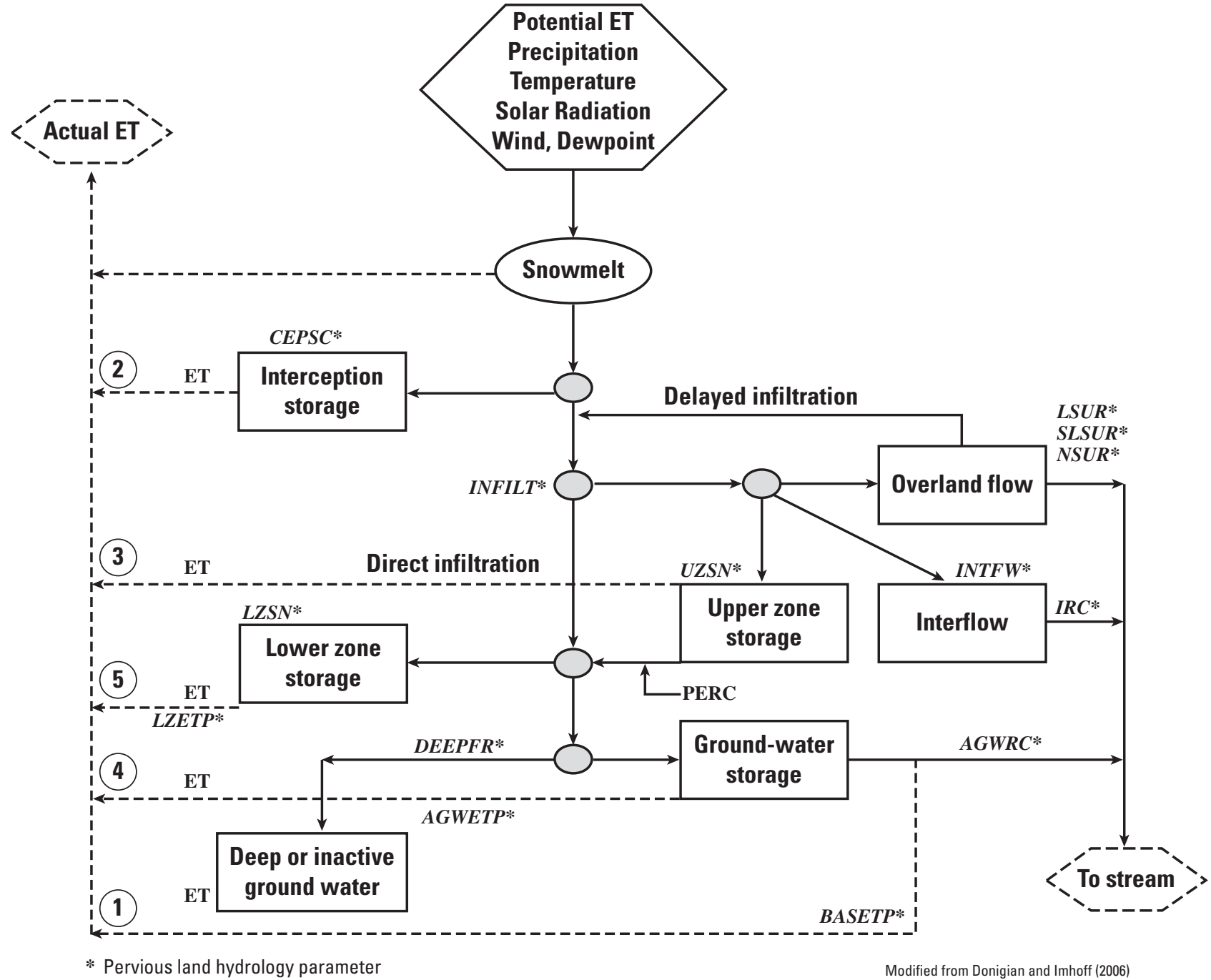

EXPLANATION

$\begin{aligned} \boldsymbol{A G W E T P *} & \text { Ground-water evapotranspiration } \\ \boldsymbol{A G W R C ^ { * }} & \text { Ground water recession constant } \\ \boldsymbol{B A S E T P *} & \text { Baseflow evapotranspiration } \\ \boldsymbol{C E P S C} * & \text { Interception storage } \\ \boldsymbol{D E E P F R} & \text { Inactive ground water } \\ \mathbf{E T} & \text { Evapotranspiration } \\ \text { INFILT* } & \text { Infiltration } \\ \text { INTFW* } & \text { Interflow-inflow }\end{aligned}$

\begin{tabular}{|c|c|}
\hline $\operatorname{IRC} C^{*}$ & Interflow recession constant \\
\hline$L S U R^{*}$ & Length of overland flow path \\
\hline LZETP* & Lower zone evapotranspiration \\
\hline$L Z S N *$ & Lower zone nominal storage \\
\hline$N S U R *$ & Roughness of overland flow path \\
\hline PERC & Perculation or delayed infiltration \\
\hline$S L S U R^{*}$ & Slope of overland flow path \\
\hline$U Z S N^{*}$ & Upper zone nominal storage \\
\hline
\end{tabular}

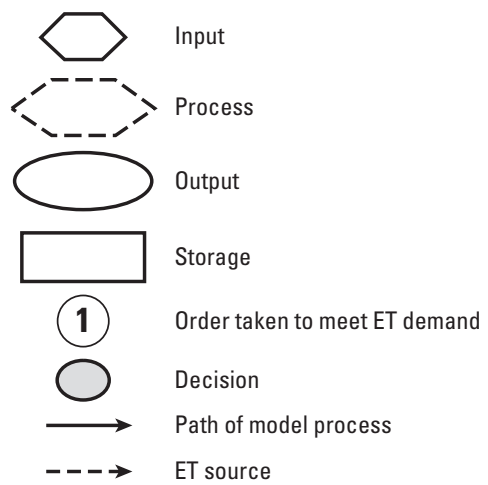

Figure 9. Schematic of pervious land hydrology module (PERLND) in the Hydrologic Simulation Program-FORTRAN. 
ing the hydrologic response for each land-cover category varied for each PERLND area unit and were determined through the model calibration procedure.

The PERLND module of the HSPF model represents the primary inputs and processes used to generate runoff from pervious land segments (fig. 9). Input into HSPF consisted of precipitation, temperature, and potential evapotranspiration (PET) data. Snowfall was so minimal (about 1 in. of water equivalent) compared to rainfall (about $42 \mathrm{in}$.) that the snowmelt module was not used in any of the upper Osage River Basin simulations; that is, all precipitation was assumed to occur in the form of rainfall. Before infiltration (fig. 9), water can be stored as plant interception/depression storage, evaporate, or runoff to the stream. After infiltration (fig. 9), water can be stored in the upper zone, lower zone, ground-water storage, or deep aquifer/inactive ground-water storage. The upper-zone storage represents water stored and available in the shallow root zone (upper 6-12 in. of soil). The amounts of overland flow and interflow are affected by the upper-zone storage quantity (fig. 9). The lower zone consists of soil and geologic material, and supplies moisture to deep-rooted vegetation. The active ground-water zone contains ground water that provides baseflow to streams. The upper zone, lower zone, and active ground-water storage all may supply water to shallow/deep rooted vegetation, and thus contribute to evapotranspiration losses (fig. 9). The magnitude of the storage components and movement of water between these processes is controlled through the HSPF model parameters provided in figure 9.

\section{Model Segmentation}

The upper Osage River Basin was too large and complex to adequately represent it as a single model within HSPF, and, therefore, initially it was sub-divided into the Marais des Cygnes, Little Osage, and Marmaton River Basins based on the eight digit Hydrologic Unit Code (HUC) boundaries. With the addition of proposed impoundments it was necessary to further divide the Marais des Cygnes River Basin into smaller model units based on the scenario simulated (fig. 10). The local model results were routed together (output from one model was used as input to the downstream model) to determine streamflows at the basin outlet near Schell City (fig. 1).

Each model was divided into meteorological segments to capture the spatial variability of precipitation and temperature. These segments (figs. 11-13) corresponded to meteorological segments utilized by the National Weather Service Missouri Basin River Forecast Center (NWS-MBRFC) in an operational hydrologic forecast model of the Missouri River Basin. Hourly mean-area meteorological time-series were computed for each segment. NWS-MBRFC delineated the meteorological segments along subbasin boundaries using the GIS-based Integrated Hydrologic Automatic Basin Boundary System (IHABBS) (NOHRSC, 2005). IHABBS uses USGS 15 arcsecond Digital Elevation Model (DEM) data and its derivatives, flow direction, and accumulation to delineate basin
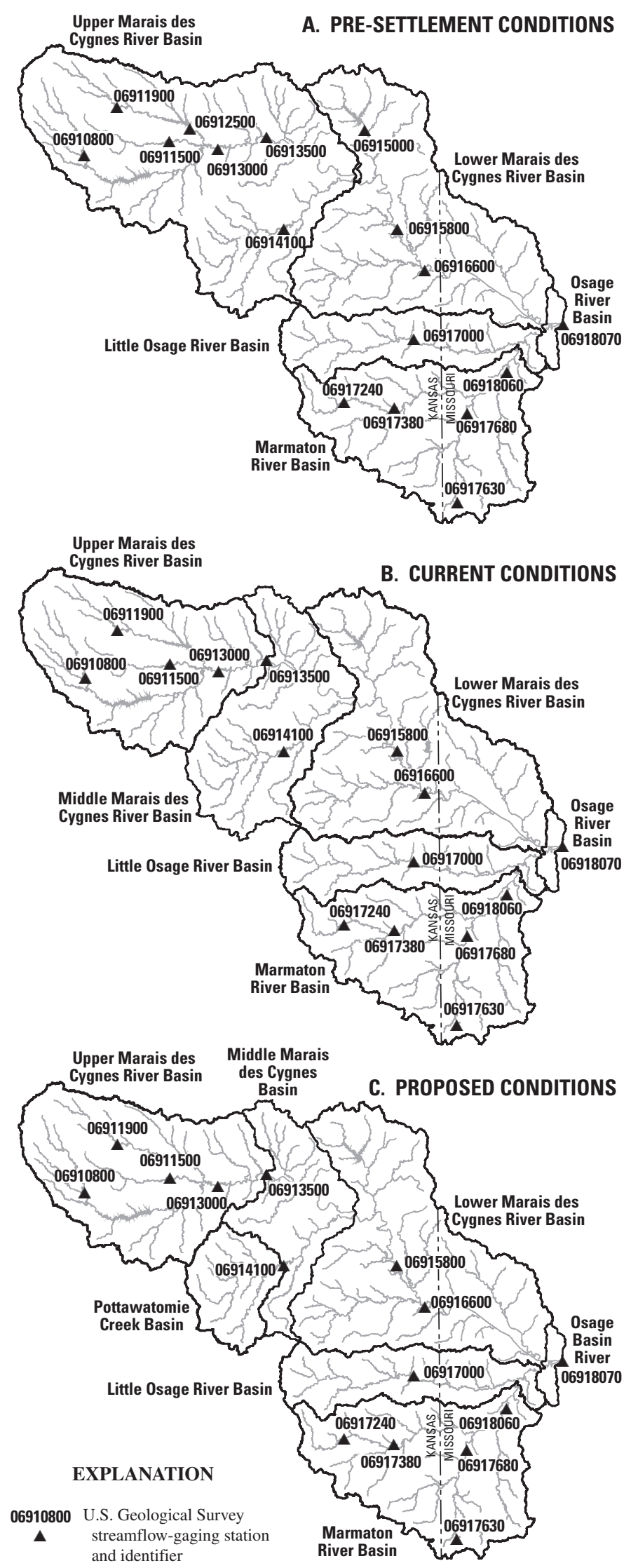

Figure 10. Upper Osage River basins for $(A)$ pre-settlement $(B)$ current, and $(C)$ proposed simulation scenarios. 


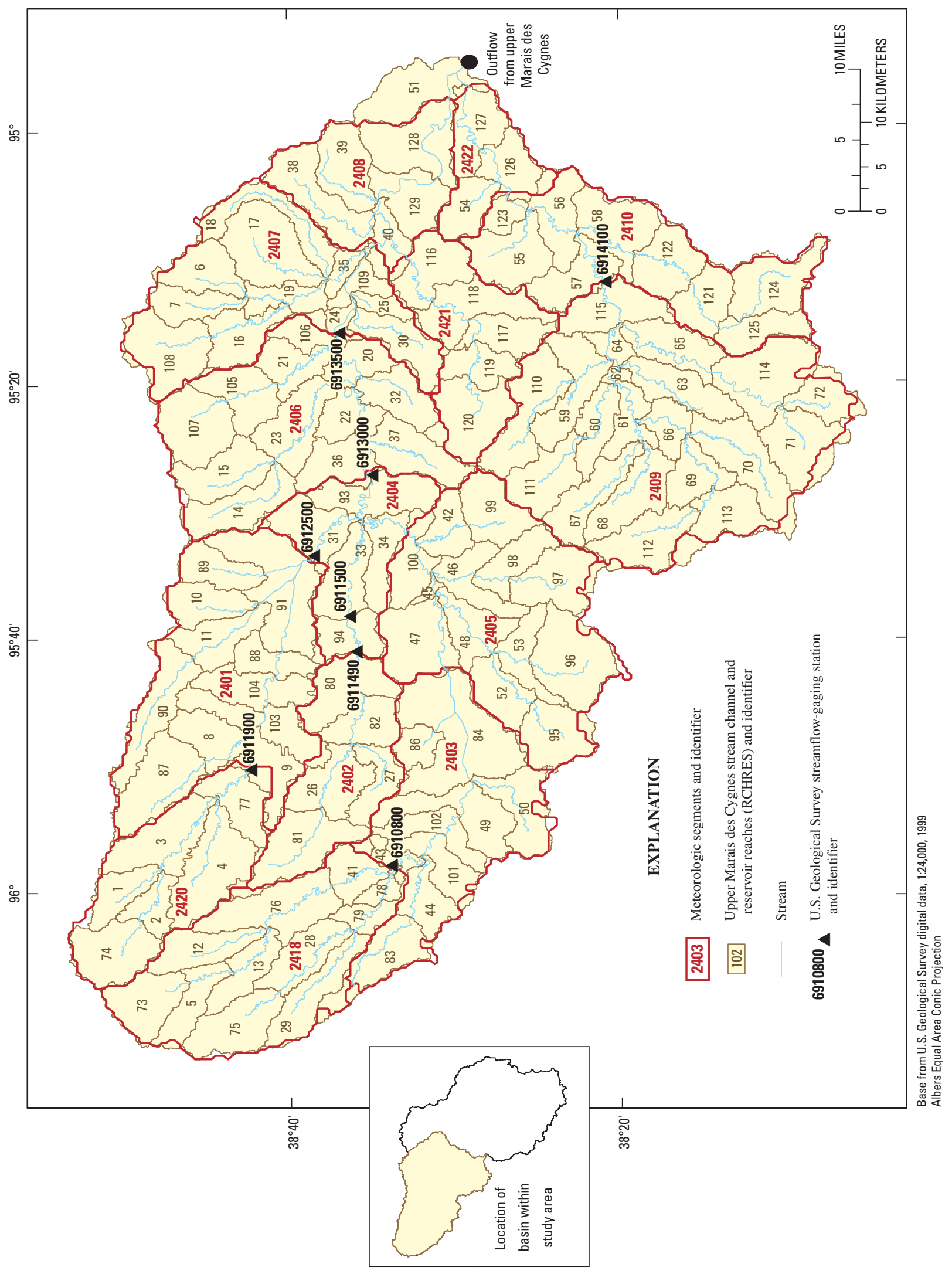




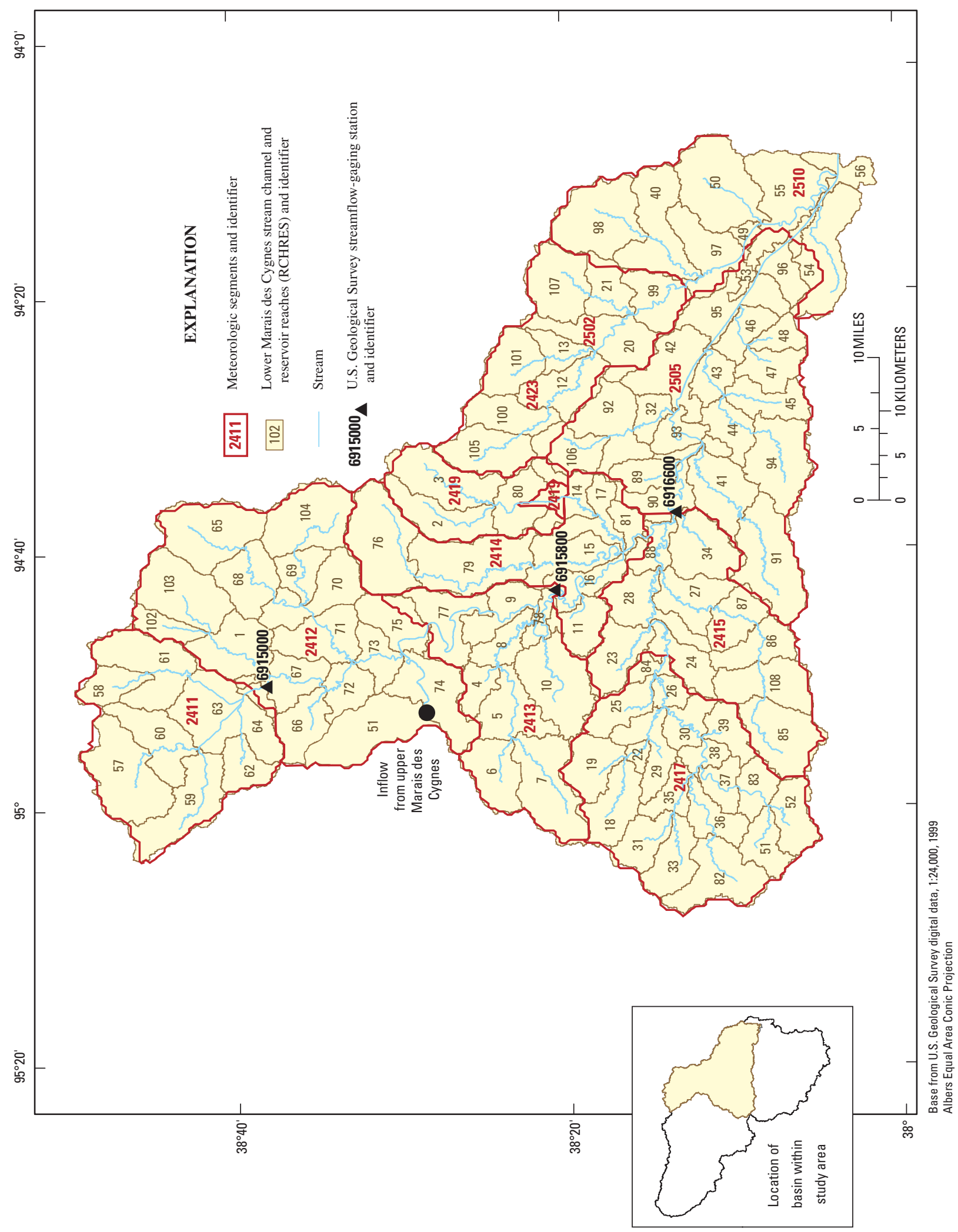




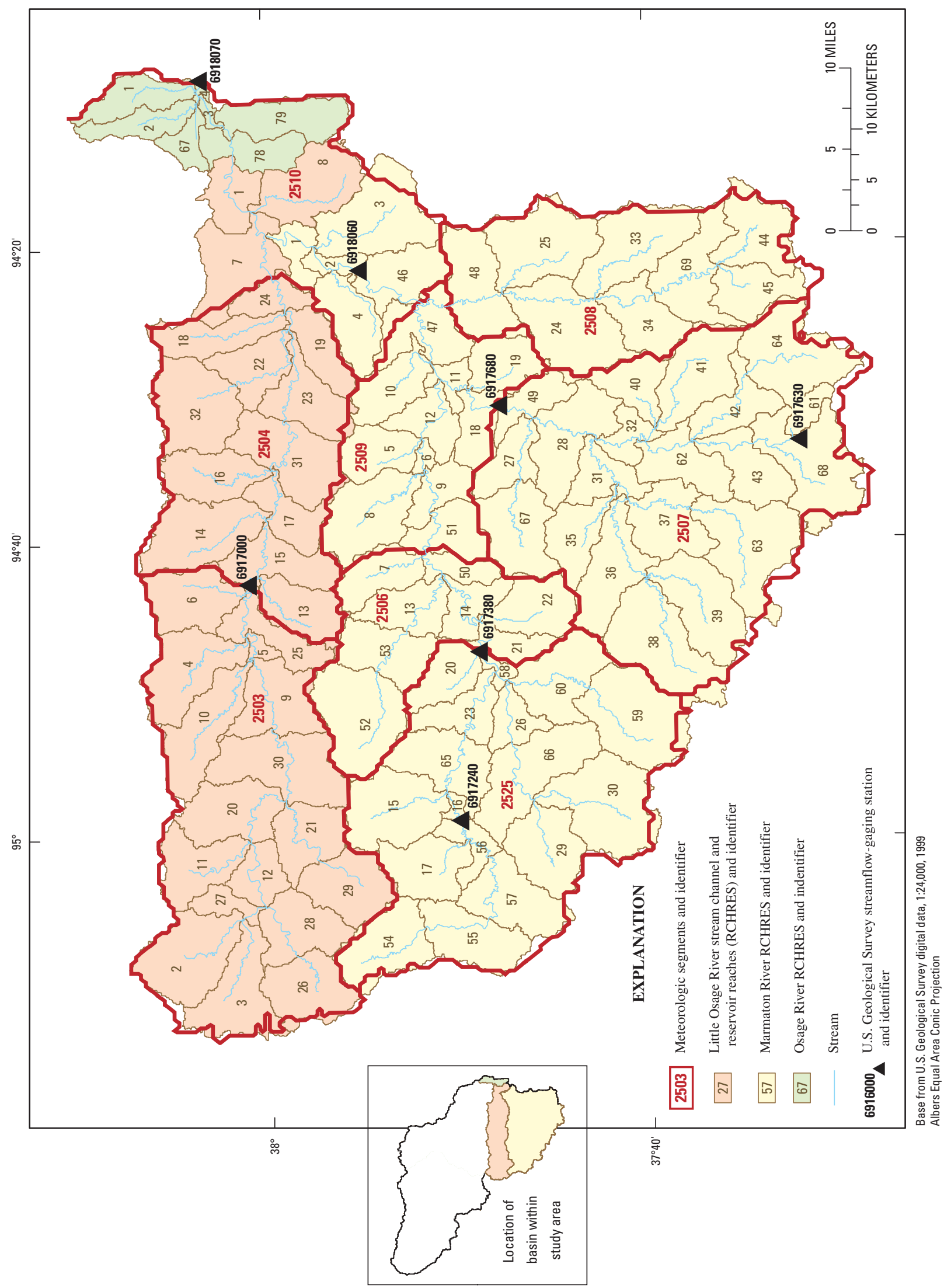

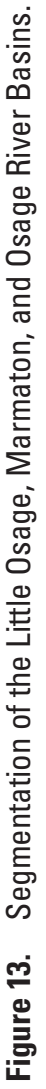


boundaries. Each meteorological segment was sized to account for the spatial and temporal availability of meteorological station data, especially precipitation (Love and Donigian, 2004). Most of the meteorological segment outlets were located at USGS streamflow gaging station locations, current NWS segment locations, and large reservoirs. Outlets for model segments 2407, 2412, 2414, 2421, 2422, 2505, and 2508 (figs. 11-13) were chosen for the HSPF application to provide better spatial resolution of the meteorological characteristics.

Stream channel and reservoir reaches (RCHRES) were developed through automatic basin delineation within the pre-processing software Better Assessment Science Integrating Point and non-point Sources (BASINS, version 3.1; U.S. Environmental Protection Agency, 2005a). BASINS is incorporated into Arcview 3.3 (Environmental Systems Research Institute, 2002) and used for the development of the initial HSPF user-control input (UCI) files (examples of UCI files for selected Marmaton River Basin model scenarios are provided in appendixes 1-3, on compact disc, at the back of this report). Digital surfaces used in the development of RCHRESs included land cover, soils, topography, hydrography, meteorological segments, streamflow-gaging stations, and dams. The DEM used in model development was obtained from the National Elevation Dataset (NED) (USGS, 2005b). National Hydrographic Data (NHD) data (USGS, 2005c) were used in the "burn-in" option when auto-delineating the subbasins. A minimum drainage area of $11.6 \mathrm{mi}^{2}$ was used for stream definition. RCHRES outlets were made to correspond with USGS streamflow-gaging station locations to allow model calibration and validation at these gages. RCHRES areas were sized to approximate a 1-hour travel time through the stream reach, which corresponded to the primary simulation-time increment. Digital surfaces of existing and proposed impoundments were used to determine where to disaggregate automatically delineated RCHRES areas that were greater than $30 \mathrm{mi}^{2}$ into more evenly distributed impoundments within RCHRES, and to better approximate the 1-hour travel time distance. The ending mean stream RCHRES size was approximately $17 \mathrm{mi}^{2}$. Each impoundment was added to the model by first assigning it to a stream RCHRES based on its reported location. A new RCHRES was created within the original stream RCHRES to represent each individual impoundment, with the size of the newly created RCHRES corresponding to the contributing drainage area of the impoundment, and the size of the original RCHRES decreased accordingly. The areas of each land-cover category of the impoundment RCHRES were assumed to be proportional to that of the original RCHRES.

\section{Time Series Data}

Hourly meteorological and hydrologic time-series data were used in simulating hourly streamflow for the Marais des Cygnes, Little Osage, and Marmaton River models, whereas the Osage River model was run using daily input and output. The most recent 10-year period of processed meteorologic and hydrologic time-series data available was from October 1, 1994, to September 30, 2004 ( the 1995 through 2004 water years); these data were used for calibration, validation, and simulation of predicted model scenarios. Meteorological data consisted of precipitation, temperature, and evapotranspiration time series, whereas hydrologic time series consisted of observed streamflow and point-source surface-water withdrawals and discharges. All time-series data were stored and accessed using binary Watershed Data Management (WDM) files.

\section{Meteorological Characteristics}

Precipitation and temperature data collected at individual meteorological stations were spatially weighted, averaged, and uniformly applied over each defined meteorological segment. Potential evapotranspiration time series data were estimated from generated temperature time series using the Hamon method (Hamon, 1961), and also uniformly applied to each meteorological segment.

USGS and National Climatic Data Center (NCDC) precipitation stations located in and around the study area were analyzed to determine the best sites to be used in a precipitation network for the Thiessen polygon analyses. Meteorologic stations were selected based on length and quality of record following the guidelines described in Anderson (2002). Precipitation data were compiled from 74 stations located in and near the study basin (fig. 14; table 3, on compact disc, at the back of this report) including stations used for disaggregating purposes and those used to estimate missing record. Precipitation stations included stations from the NCDC daily cooperative network, NCDC hourly precipitation observations, hourly precipitation data collected at USGS streamflow-gaging stations, and one unofficial National Weather Service (NWS) daily observation site.

The precipitation station data were examined for consistency in addition to general quality and applicability. Station consistency is defined as the relation between observed record for a particular station and other stations within the network during the study period. This check helps ensure that the data are not biased with time, within the calibration period or between the model calibration and validation periods. A double-mass analysis was used to check the station consistency using techniques contained in the National Weather Service River Forecast Center's (NWSRFS) calibration system Interactive Double Mass Analysis (IDMA) program (National Weather Service Office of Hydrologic Development, 1999; Pan and others, 1998). Guidelines for making resulting adjustments to the data are described by Anderson (2002). The adjustment factor is a multiplier that is applied to each data value in the time-series for the period of inconsistent record. Adjustment factors for this study varied from 0.85 to 3.5 (table 3 ) and the median adjustment factor was 1.30. Except for three daily reporting precipitation stations, all adjustment factors were applied to hourly reporting stations. Hourly tipping-bucket recording precipitation gages generally undercatch compared 
to co-located or nearby daily observation stations (Hanson and others, 1996; Groisman and others, 1999) and, therefore, were used primarily for timing of disaggregation of daily stations. All adjustment factors were applied before the station data were used to compute mean areal precipitation values.

Hourly mean areal precipitation characteristics for each meteorological segment were calculated by the NWS Missouri Basin River Forecast Center using the Thiessen polygon analysis method contained in the NWSRFS's calibration system (National Weather Service Office of Hydrologic Development, 2004). A set of Thiessen polygons was computed for each meteorological segment using a common network of 39 precipitation stations (fig. 14). In using the Thiessen polygon method a separate set of precipitation station weights were computed for each segment (table 3) to represent the spatial affect each precipitation station had within the segment. Daily and hourly precipitation recording sites (fig. 14) were used in the creation of mean areal precipitation time-series.

After the adjustment factors were determined, all the mean areal precipitation time-series were computed using a utility in NWSRFS's calibration system. This utility applied the adjustment factors, computed the Thiessen weights for each meteorological segment (table 3 ), estimated any missing daily or hourly values, disaggregated the daily into hourly observations, and computed a mean areal precipitation timeseries for each meteorological segment (National Weather Service Office of Hydrologic Development, 2004). Only 11 out of 31 meteorological segments used hourly stations in the Thiessen station weight analysis. Hourly precipitation observations were considered to be less consistent than daily observations, and were not used to compute mean areal precipitation except where the spatial coverage of the daily observations was considered inadequate. Because hourly USGS precipitation sites did not exist from October 1994 through September 1995 , only NCDC hourly stations were used for this period to disaggregate the daily observations.

The hourly mean areal temperature characteristics for each meteorologic segment were computed from a network of 26 NCDC daily stations reporting daily maximum and minimum temperatures (fig. 15; table 4, on compact disc, at the back of this report). Station selection and quality-control procedures followed the methods outlined for precipitation stations. Missing temperatures were estimated using the nearest station. The areal station weights - a measure of the spatial affect of the temperature station on the meteorological segment_-were calculated using the gridded methods in the NWSRFS calibration system for computing mean areal temperature (National Weather Service Office of Hydrologic Development, 2004). The final mean areal temperature daily maximum and minimum values for each meteorological segment were calculated by multiplying the station weights by the daily station temperatures and summing the weighted daily temperatures for each segment. The program WDMUtil (U.S. Environmental Protection Agency, 2005b; available at U.S. Environmental Protection Agency, 2005a) was used to disaggregate the minimum and maximum temperatures into hourly values using a fixed diurnal temperature pattern because the hours of the daily maximum and minimum temperatures were not known.

Hourly potential evapotranspiration time series were computed using the Hamon Method (Hamon, 1961) within the USGS program WDMutil (U.S. Environmental Protection Agency, 2005b; available at U.S. Environmental Protection Agency, 2005a). The Hamon method is a simplified potential evapotranspiration estimate utilizing the latitude, hourly temperature, and monthly constants as input. The default monthly constants within WDMutil were used for all the Hamon evapotranspiration calculations.

\section{Hydrologic Characteristics}

All documented point-source withdrawals and discharges in the upper Osage River study basins were included in the HSPF hydrologic simulations. Observed hourly streamflows were used for calibration and validation of the simulated streamflow conditions at each streamflow gage location, with the exception of the Osage River near Schell City, Missouri, streamflow gage location where mean daily values were used.

Point-source surface-water withdrawals (including those for municipal, industrial, irrigation, and recreation uses) from the Kansas part of the upper Osage River Basin were reported either monthly or annually from the Kansas Department of Agriculture, Division of Water Resources (Joe File, Kansas Department of Agriculture, Division of Water Resources, written commun., 2005). There were 162 permitted withdrawals affecting 42 RCHRESs in the Kansas part of the upper Osage River Basin (fig. 16). Annual estimates from 23 documented withdrawals were available for the Missouri part of the upper Osage River Basin from "major users" as defined by Missouri Department of Natural Resources (Amy Crews, Missouri Department of Natural Resources, Missouri Water Resources Center, written commun., 2005). The annual or monthly municipal and industrial withdrawals were disaggregated into daily values based on communications with the water-use entities. The daily values were then evenly disaggregated into hourly values using the disaggregation function within WDMutil. Reported annual irrigation withdrawals in Kansas and Missouri were distributed during July and August of each year as this is the primary irrigation period in the basins (Vernon County Missouri Office of the University of Missouri Extension service, oral commun., 2004). Withdrawals in each model basin primarily were from surface- rather than ground-water sources-either directly from a river or a surface-water impoundment (fig. 17). Runoff retained in selected Kansas recreational impoundments was classified as a permitted withdrawal, and such withdrawals were not included in the HSPF models. Only those withdrawals that were obtained directly from a stream channel (as opposed to an impoundment) and used for a purpose other than impoundment storage were included in the HSPF simulations.

Discharges for nine Kansas permitted point-source discharges at 13 locations (fig. 16) were obtained from the 


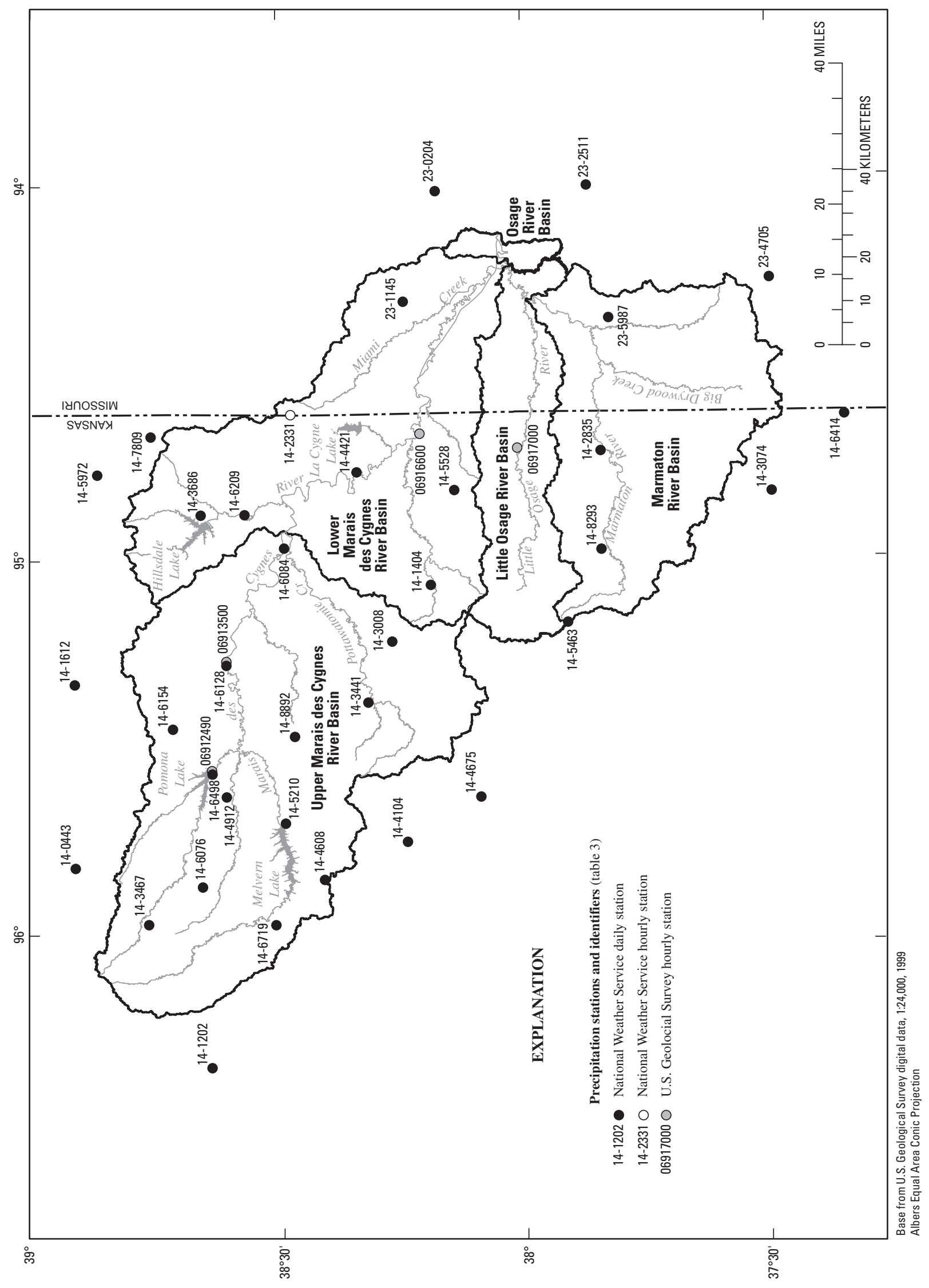

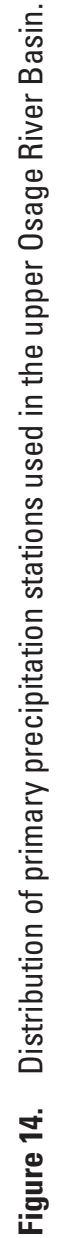




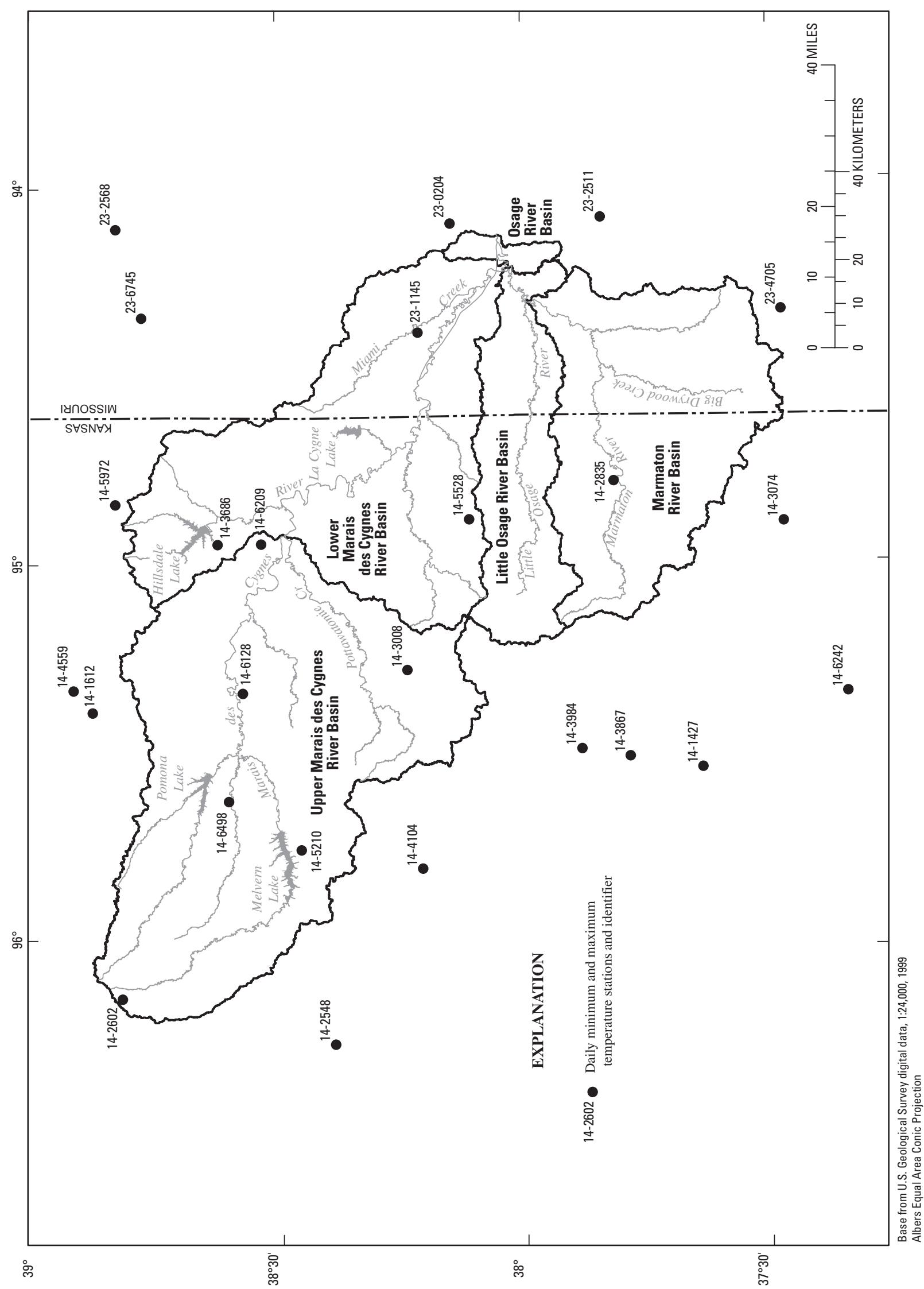




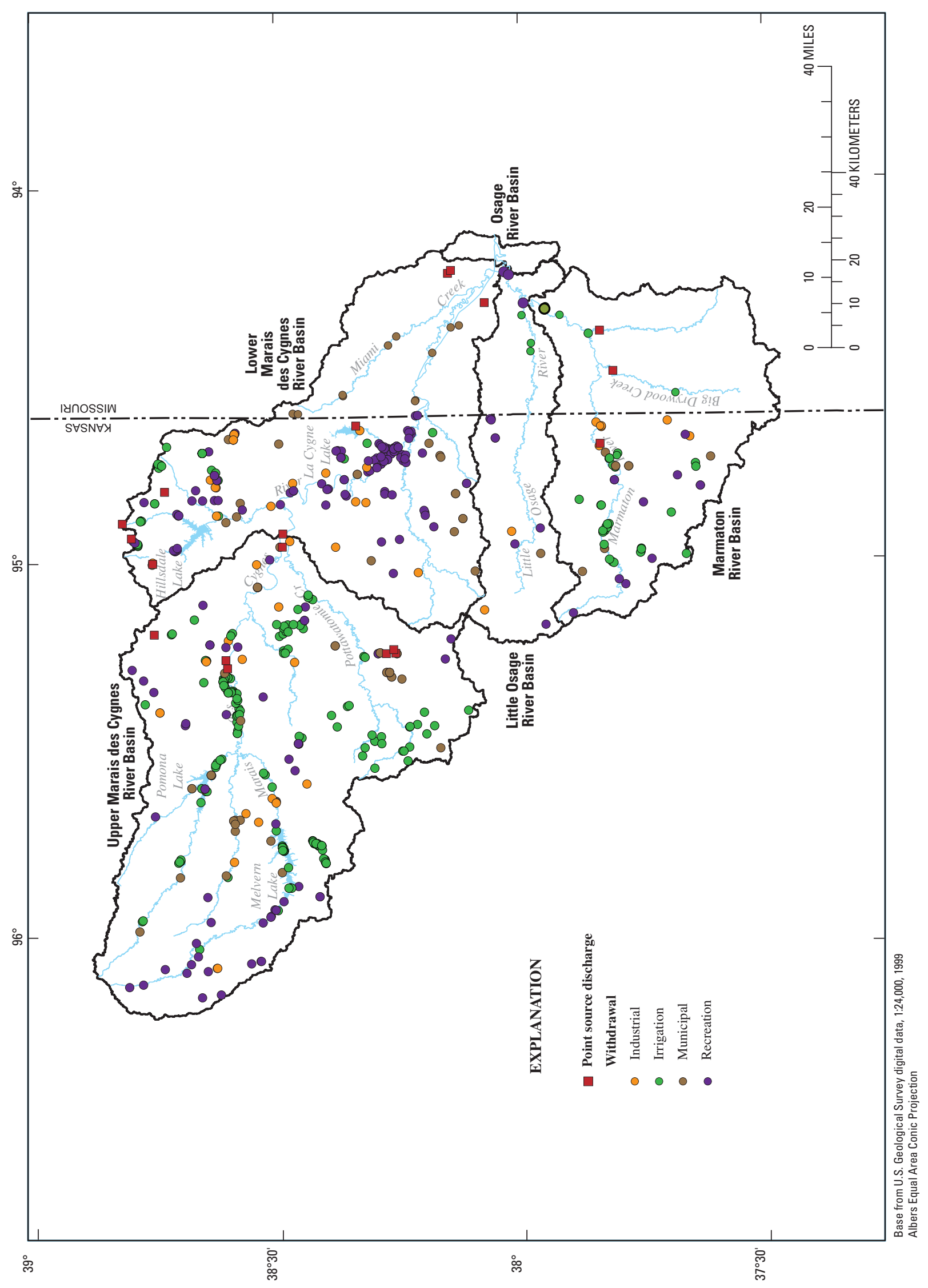




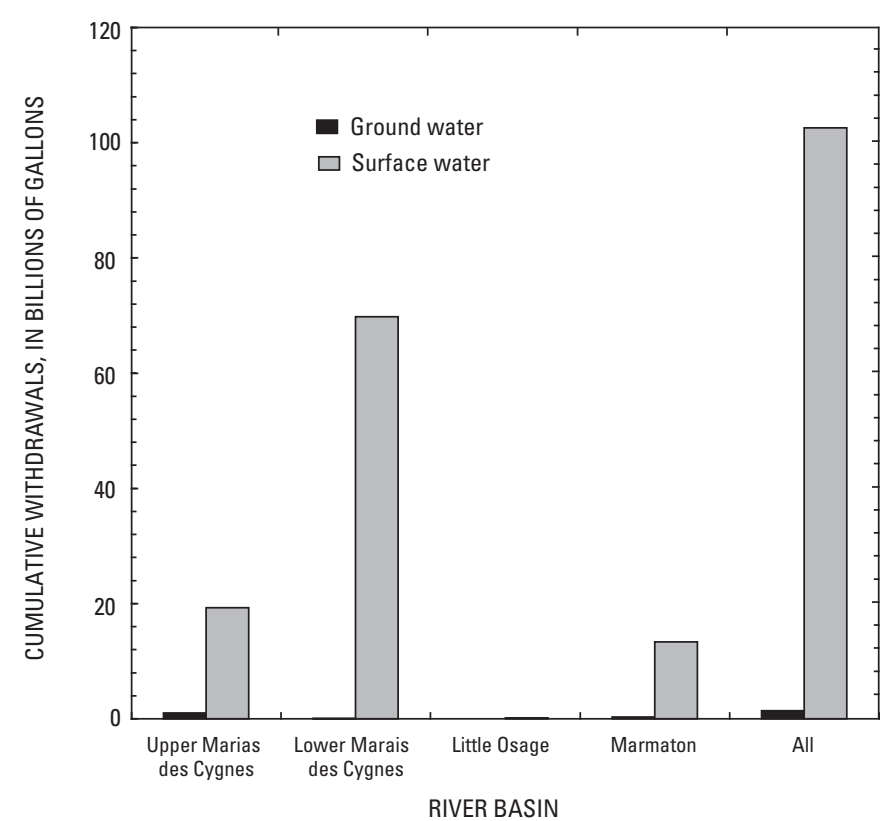

Figure 17. Comparison of cumulative reported ground-water and surface-water withdrawals in the upper Osage River Basin, water years 1995 though 2004.

Kansas Department of Health and Environment (KDHE, Ed Dillingham, Kansas Department of Health and Environment, written commun., 2005) and reported daily or monthly. Point discharges for three Missouri primary water users at five locations (fig. 16; Amy Crews, Missouri Department of Natural Resources, written commun., 2005) also were incorporated into the models. Discharges were primarily associated with municipal (sewage effluent) sources, but also included industrial sources. Monthly values were disaggregated into daily and then hourly values by assuming a constant rate of discharge during the day or month.

Reported point-source withdrawals in the Marais des Cygnes, Little Osage, and Marmaton River Basins generally exceeded point-source discharges (fig. 18). Cumulative reported point-source withdrawals in the Marais des Cygnes Basin generally were less than $40 \mathrm{ft}^{3} / \mathrm{s}$ but reached a maximum of about $90 \mathrm{ft}^{3} / \mathrm{s}$ in 2002 (fig.18). Cumulative reported discharges in the Marais des Cygnes Basin were less than 10 $\mathrm{ft}^{3} / \mathrm{s}$, with net basin loss of about $8 \mathrm{ft}^{3} / \mathrm{s}$ during non-irrigation periods and a net loss of about $80 \mathrm{ft}^{3} / \mathrm{s}$ during irrigation periods (fig. 18). Reported withdrawals in the Little Osage River Basin generally were less than $2 \mathrm{ft}^{3} / \mathrm{s}$, and there were no reported point-source discharges in this basin. Cumulative reported point-source withdrawals generally were under $3 \mathrm{ft}^{3} / \mathrm{s}$ in the Marmaton River Basin, except during summer irrigation (July-August) when estimated withdrawals could exceed $7 \mathrm{ft}^{3} / \mathrm{s}$ (fig. 18). Cumulative point-source discharges in the Marmaton River Basin generally were less than $1 \mathrm{ft}^{3} / \mathrm{s}$ resulting in a net loss of about $2 \mathrm{ft}^{3} / \mathrm{s}$ in flows during non- irrigation periods, and as much as about $6 \mathrm{ft}^{3} / \mathrm{s}$ during irrigation periods.

Most of the reported total annual withdrawal volume in the modeled Marais des Cygnes Basin for 1995-2000 was for municipal purposes (fig. 19); however, the primary use for the total annual withdrawals from 2001 through 2003 was for recreation purposes, whereas in 2004 the primary withdrawal use

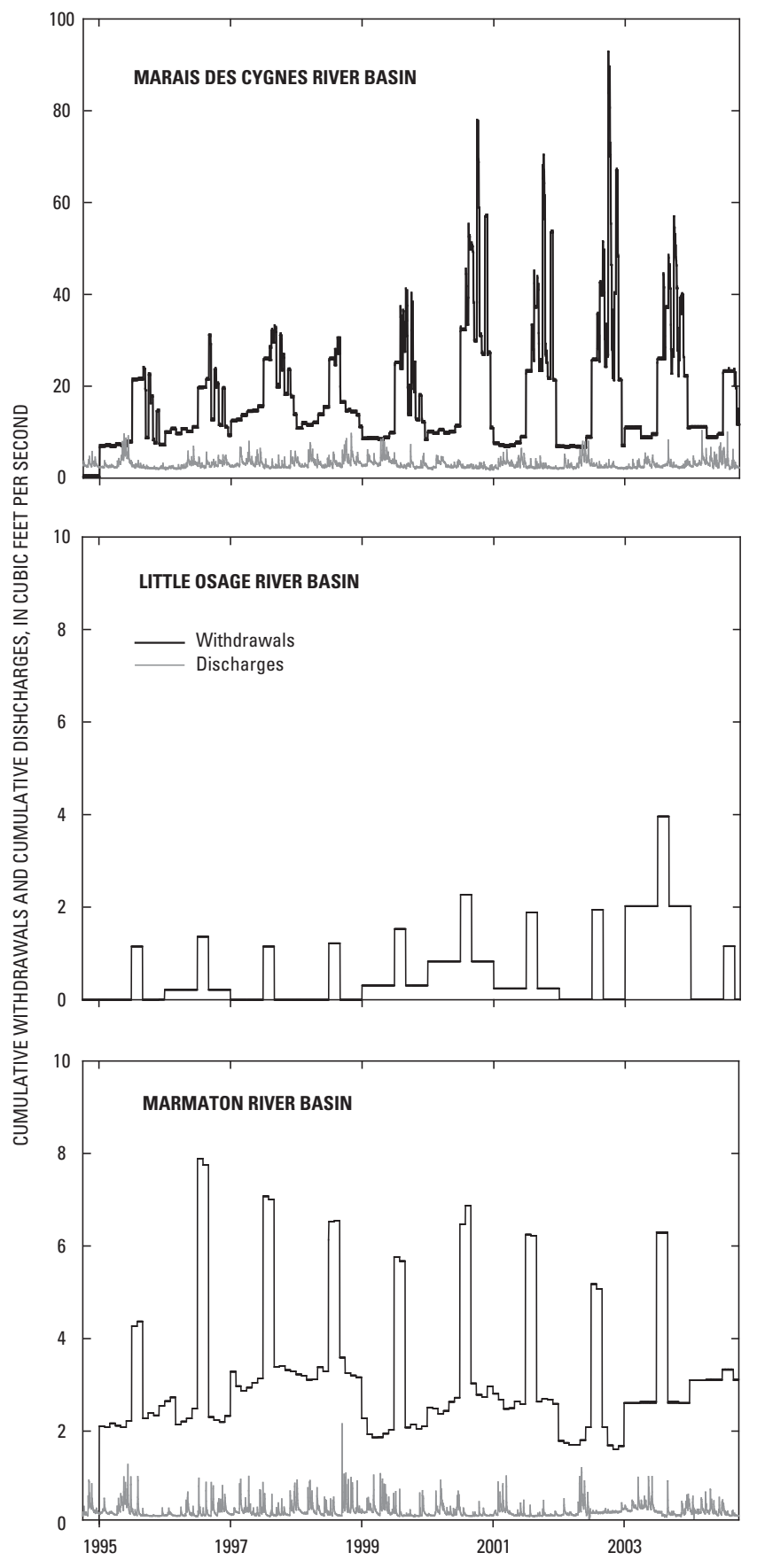

Figure 18. Temporal distribution of point-source withdrawals and discharges in the Marais des Cygnes, Little Osage, and Marmaton River Basins, water years 1995 through 2004. 
was again municipal. Irrigation and recreation were the two primary use categories for the reported total annual withdrawals for the Little Osage model basin (fig. 19), whereas municipal and irrigation withdrawals were the primary withdrawal categories for the Marmaton River Basin (fig. 19).

Observed streamflow records from 20 USGS continuous streamflow-gaging stations were used for calibration/validation for all or part of the 1995-2004 study period (table 5, fig. 10). The hourly observed record from the USGS streamflowgaging stations below the large reservoirs in Kansas (Pomona, Melvern, and Hillsdale reservoirs; fig. 1) were used as input points for the current (2005) and proposed Marais des Cygnes
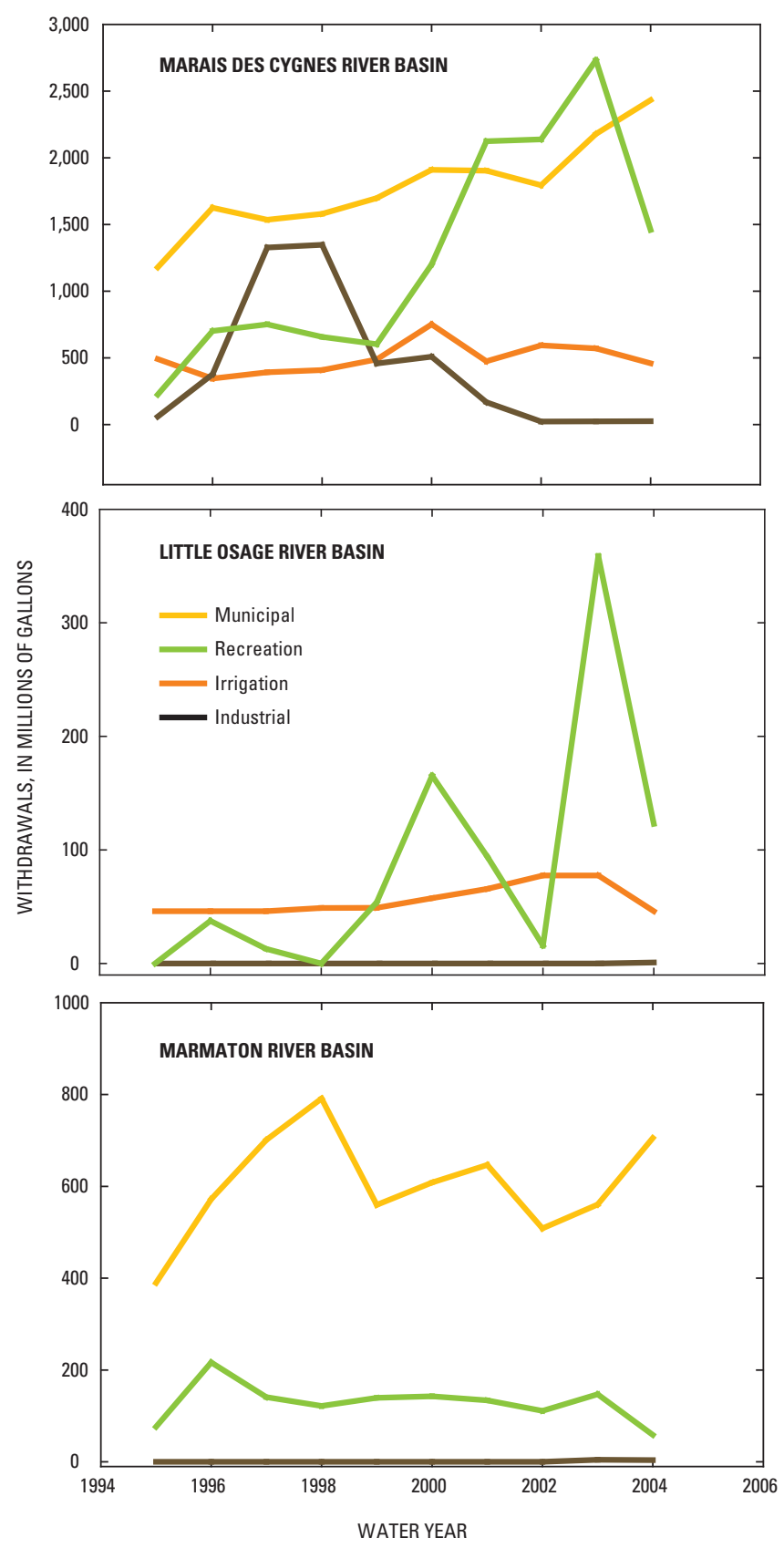

Figure 19. Annual reported surface-water withdrawals, by basin and water-use category, water years 1995 through 2004.
River simulation scenarios; the observed outflows from the reservoirs were used instead of simulating runoff upstream from, and routing streamflows through, the large reservoirs in the current and proposed models. The outflow from LaCygne Lake (fig. 1) also was used as a model input point rather than simulating runoff into and through this reservoir. The outflow from LaCygne Lake was estimated based on daily lake stage and stage/outflow rating provided by the LaCygne Power plant (Bruce Beckman, Kansas City Power and Light Company, written commun., 2005).

\section{Stage-Area and Stage-Volume Outflow Relations}

Relations between water depth and surface area, volume, and outflow were developed for all model channel reaches and impoundments (all RCHRESs). Volume-outflow relation tables (FTABLEs) were developed for each RCHRES by BASINS in the development of the initial UCI file based on channel geometry and slope derived from the input DEM. Whereas the HSPF hydrologic simulations are relatively insensitive to the FTABLES for streamflow-only applications (Alan Lumb, U.S. Geological Survey, oral commun., 2004; Tony Donigian, Aqua-Terra Consultants, oral commun., 2004), the original FTABLES were replaced with tables derived manually for both stream channel and impoundment RCHRESs to increase the accuracy of streamflow routing.

Initial hydrologic conditions were specified for each stream and impoundment RCHRES in the models. Flow conditions for each stream RCHRES were set to observed discharges at the beginning of the simulation. The initial volumes for impoundments generally were set at 75 percent of capacity, based in part on quarterly permitee information provided to the Kansas Department of Agriculture (Joe File, Kansas Department of Agriculture, written commun., 2005).

FTABLES for stream RCHRESs were developed using the USGS programs CGAP and GenFtable (Regan and Schaffranek, 1985; available at USGS, 2005d). Data input consisted of channel cross section, slope, and Mannings " $n$ " roughness coefficients for each computation reach. Channel cross sections were obtained from discharge measurements at USGS streamflow-gaging station locations, measured cross sections within the upper Marmaton Basin (Ed Radatz, Natural Resource Conservation Service, written commun., 2005), or measured cross sections available for the Marmaton and Marais des Cygnes Rivers from a previous study of hydraulic conditions and fish habitat (Heimann and others, 2005). Data from 64 measured cross sections were applied to the remaining 278 unmeasured sites based on similarities in contributing drainage area. Channel slope for each RCHRES was obtained from the BASINS analyses of the input DEM. Manning's "n" roughness coefficients were estimated from a calibrated onedimensional model of the upper Marmaton River (Ed Radatz, USDA NRCS, written commun., 2005) and from calibrated two-dimensional models of selected reaches of the Marmaton 
Table 5. U.S. Geological Survey streamflow-gaging stations used in the development and calibration/validation of the upper Osage River Basin models.

[USGS, U.S. Geological Survey; streamflow records for stations in gray were combined for calibration/validation]

\begin{tabular}{|c|c|c|c|}
\hline $\begin{array}{c}\text { USGS } \\
\text { streamflow- } \\
\text { gaging } \\
\text { station } \\
\text { number }\end{array}$ & Station name & $\begin{array}{l}\text { Drainage area, } \\
\text { in square miles }\end{array}$ & $\begin{array}{l}\text { Period of discharge } \\
\text { record }\end{array}$ \\
\hline 06910800 & Marais des Cygnes river near Reading, Kansas & 177 & 1969-2004 \\
\hline 06911490 & Salt Creek at Lyndon, Kansas & 97.8 & 1999-2003 \\
\hline 06911500 & Salt Creek near Lyndon, Kansas & 111 & 1940-1999 \\
\hline 06911900 & Dragoon Creek near Burlingame, Kansas & 114 & 1960-2004 \\
\hline 06912500 & Hundred and Ten Mile Creek near Quenemo, Kansas & 322 & 1939-2004 \\
\hline 06913000 & Marais des Cygnes River near Pomona, Kansas & 1,040 & $\begin{array}{c}\text { 1922-1938; } \\
1968-2004\end{array}$ \\
\hline 06913500 & Marais des Cygnes River near Ottawa, Kansas & 1,250 & 1918-2004 \\
\hline 06914000 & Pottawatomie Creek near Garnett, Kansas & 334 & 1939-2001 \\
\hline 06914100 & Pottawatomie Creek near Scipio, Kansas & 343 & 2001-2004 \\
\hline 06915000 & Big Bull Creek near Hillsdale, Kansas & 147 & 1958-2004 \\
\hline 06915800 & Marais des Cygnes River at La Cygne, Kansas & 2,670 & 1984-2004 \\
\hline 06916600 & Marais des Cygnes River near Kansas-Missouri state line, Kansas & 3,230 & 1958-2004 \\
\hline 06917000 & Little Osage River at Fulton, Kansas & 295 & 1948-2004 \\
\hline 06917240 & Marmaton River at Uniontown, Kansas & 84 & 2001-2004 \\
\hline 06917380 & Marmaton River near Marmaton, Kansas & 292 & 1971-2004 \\
\hline 06917630 & East Drywood Creek at Prairie State Park, Missouri & 3.92 & 2001-2004 \\
\hline 06917680 & Dry Wood Creek near Deerfield, Missouri & 358 & 2001-2004 \\
\hline 06918060 & Marmaton River near Nevada, Missouri & 1,070 & 2003-2004 \\
\hline 06918065 & Marmaton River below Nevada, Missouri & 1,090 & 2000-2003 \\
\hline 06918070 & Osage River above Schell City, Missouri & 5,410 & 1981-2004 \\
\hline
\end{tabular}

and Marais des Cygnes River Basins (Heimann and others, 2005) for 48 cross sections. At the remaining 294 sites for which no roughness information was available, Manning's " $n$ " values were assigned based on roughness values of reaches with similar contributing drainage area.

FTABLES for each of 539 existing (2005) and 283 proposed impoundments were developed in the HSPF simulations using impoundment design specifications obtained from the National Inventory of Dams (U.S. Army Corps of Engineers, 2005); the Kansas Department of Agriculture, Division of Water Resources (Joe File, Kansas Department of Agriculture, Division of Water Resources, written commun., 2005); and stage-discharge relations developed for culvert and weir structures. The number of impoundments simulated in this study is a conservative estimate as an impoundment is included in the National Inventory of Dams only if it's "high" or has a "significant" hazard potential dam, or is a "low" hazard potential dam that exceeds $25 \mathrm{ft}$ in height and 15 acre-ft of storage, or has a "low" hazard potential dam that exceeds $6 \mathrm{ft}$ in height and 50 acre-ft of storage (U.S. Army Corps of Engineers, 2005). The National Inventory of Dams data were augmented with a listing of all permitted reservoirs within the upper Osage River Basin in Kansas as maintained by the Kansas Department of Agriculture, Department of Water Resources (Joe File, Kansas Department of Agriculture, Division of Water Resources, written commun., 2005). Impoundment specifications in the National Inventory of Dams included contributing drainage area, water volumes, and surface areas at the primary and emergency spillway levels, along with dimensions of the primary and secondary spillway structures. The outflow from the primary spillway culvert was determined using reservoir water depth, culvert diameter, and an outflow relation defined in Ward and Elliot (1995) provided in table 6. These primary spillway outflow values were corrected for culvert length (Ward and Elliot, 1995) using corrections provided in table 7. Culvert length was estimated from a formula computed from known impoundment 
characteristics (Joe File, Kansas Department of Agriculture, Division of Water Resources, written commun., 2005) as:

$$
\mathrm{L}_{\mathrm{c}}=\mathrm{H}_{\mathrm{d}} \times 5.5+20
$$

where

$\mathrm{L}_{\mathrm{c}} \quad$ is culvert length, in $\mathrm{ft}$; and
$\mathrm{H}$

The emergency spillway water depth-outflow relation was defined using the following equation for a broad crested weir as defined in Hulsing (1967)

$$
\mathrm{Q}=\mathrm{C} b \mathrm{H}^{3 / 2}
$$

where

$$
\begin{aligned}
& \text { Q is discharge in } \mathrm{ft}^{3} / \mathrm{s} \\
& \mathrm{C} \text { is a coefficient of discharge (assumed value of } \\
& \text { 3.1) }
\end{aligned}
$$$$
b \text { is width of the weir normal to the flow, in } \mathrm{ft}
$$$$
\mathrm{H} \text { is total energy head }\left(\mathrm{h}+\mathrm{V}_{1}{ }^{2} / 2 \mathrm{~g} \text { where } \mathrm{h}=\right.
$$
static head and $\mathrm{V}_{1}$ is the mean velocity at the approach section to the weir, and $g=$ acceleration because of gravity), in feet. For the purpose of this application it was assumed that the total energy head was equal to the depth of water above the weir crest.

Total outflow was calculated for each impoundment as the sum of the corrected primary outflow and the calculated emergency spillway outflows.

For all but 35 impoundments there was at least one missing outflow design specification; these missing values were estimated based on correlations of design specification for reservoirs with existing information. Missing contributing drainage area, surface area at primary and emergency spillway elevations, and storage volumes at the primary and emergency spillway elevations were estimated using a simple linear regression equation developed from known data within each model basin (table 8). Missing values for those relations of impoundment characteristics that did not follow a simple linear expression were estimated by using categorical breaks in graphical relations between predictive design specifications. The relations between detention volume and dam height (table 9), detention volume and elevation difference between primary and emergency spillways (table 10), impoundment drainage area and primary spillway culvert diameter (table 10), and drainage area and emergency spillway width (table 10) were plotted, and slope breaks were used to define three to five discrete categories. The distribution within these categories was used in defining the relation between variables shown in tables 9-10. As culverts are manufactured in fixed diameters, the relation between drainage area and culvert diameter yielded a discrete culvert size estimate for each of five established contributing drainage area categories (table 10).

To quantify the range of variation that might result from estimating unknown impoundment design variables, three outflow ratings, or FTABLES, were constructed for each impoundment with an estimated outflow design variable (these included primary culvert diameter, spillway width, and/or elevation differential between primary and secondary spillway). These three outflow ratings $\left(10^{\text {th }}-, 50^{\text {th }}\right.$-, and $90^{\text {th }}$-percentile rating) were constructed using all reported impoundment design information, and an estimate of the corresponding $10^{\text {th }}$ -, $50^{\text {th }}$, or $90^{\text {th }}$-percentile design values (table 10) only for any missing outflow design variables. The $10^{\text {th }}$-percentile design scenario was representative of the smallest outflow structures, from the distribution of reported specifications, and had the longest detention times, whereas the $90^{\text {th }}$-percentile design scenario was representative of largest reported outflow structures, and had the shortest detention times. The $10^{\text {th }}$-percentile rating scenario would, for instance, include FTABLES constructed using

\begin{tabular}{|c|c|c|c|c|c|}
\hline \multirow{2}{*}{$\begin{array}{l}\text { Water depth, } \\
\text { in feet }\end{array}$} & \multicolumn{5}{|c|}{ Pipe diameter, in inches } \\
\hline & 18 & 24 & 30 & 36 & 48 \\
\hline 1 & 5.47 & 11.0 & 18.8 & 28.8 & 55.7 \\
\hline 3 & 9.48 & 19.1 & 32.6 & 49.9 & 96.5 \\
\hline 4 & 10.9 & 22.1 & 37.6 & 57.7 & 111 \\
\hline 6 & 13.4 & 27.0 & 46.1 & 70.6 & 136 \\
\hline 8 & 15.5 & 31.2 & 53.2 & 81.5 & 158 \\
\hline 10 & 17.3 & 34.9 & 59.5 & 91.2 & 176 \\
\hline 12 & 19.0 & 38.2 & 65.2 & 99.9 & 193 \\
\hline
\end{tabular}
the $10^{\text {th }}$ percentile value from distributions of known values for any missing impoundment outflow variable for all impoundments in a particular model basin. In this way the sensitivity of

Table 6. Pipe flow outflow rates, in cubic feet per second, with varying pipe diameter and water depths (from Ward and Elliot, 1995). 
Table 7. Correction factors (dimensionless) for spillway culvert pipe lengths (from Ward and Elliot, 1995).

\begin{tabular}{cllccc}
\hline \multirow{2}{*}{$\begin{array}{c}\text { Pipe length, } \\
\text { in feet }\end{array}$} & $\mathbf{1 8}$ & $\mathbf{2 4}$ & $\mathbf{3 0}$ & $\mathbf{3 6}$ & $\mathbf{4 8}$ \\
\hline & $\mathbf{1 8}$ & 1.34 & 1.28 & 1.24 & 1.18 \\
30 & 1.42 & 1.24 & 1.21 & 1.18 & 1.13 \\
40 & 1.29 & 1.17 & 1.14 & 1.12 & 1.10 \\
50 & 1.20 & 1.1 & 1.09 & 1.08 & 1.06 \\
60 & 1.12 & 1.05 & 1.04 & 1.04 & 1.03 \\
70 & 1.05 & 1.00 & 1.00 & 1.00 & 1.00 \\
80 & 1.00 & .96 & .96 & .97 & .97 \\
90 & .95 & .92 & .93 & .94 & .95 \\
100 & .91 & .89 & .90 & .91 & .93 \\
120 & .83 & .85 & .86 & .89 \\
140 & .82 & .79 & .81 & .82 & .85 \\
160 & .77 & .75 & .77 & .79 & .82 \\
\hline
\end{tabular}

model results to the estimation of design criteria, representing a range of possible detention characteristics, could be quantified, and the effects of altering outflow structures of proposed impoundments also could be assessed. FTABLEs for existing (2005) impoundments were developed using the $50^{\text {th }}$-percentile value from the distribution of known values for any estimated outflow variables, and these median condition FTABLES were used for calibration and validation scenarios.

Whereas the number of proposed reservoirs is about one-half that of existing (2005) impoundments, the proposed reservoirs provide significantly higher median detention storage [Mann-Whitney test (Helsel and Hirsch, 1992), p<0.001; significance level $=0.05]$ and regulated contributing drainage area $(\mathrm{p}<0.001)$ when compared to existing impoundments (fig. 20). Median detention storage in proposed impoundments is 400 percent greater than existing median impoundment storage in the Marais des Cygnes River Basin, 428 percent greater in the Marmaton River Basin, and 358 percent greater in the entire upper Osage River Basin.

\section{Model Calibration, Validation, Sources of Error, and Model Uncertainty}

Calibration of the HSPF models was conducted by minimizing differences between simulated and observed streamflow data at model locations corresponding to USGS streamflowgaging stations by adjusting model process-related parameters. Validation was used to test the calibration on an independent data set. In addition to the calibration and validation techniques and results, the possible sources of error in the model representation are discussed, along with uncertainties in the model results and techniques used to minimize these uncertainties.

\section{Calibration and Validation Methods}

Calibration is the process by which the mathematical model process-related parameters are adjusted such that simulated results are fitted to observed data. Simulated results were fitted to observed data by varying model parameters through "trial and error" and determining fit using the weight-of-evidence approach as described in Donigian (2002). Because the "trial and error" calibration process was subjective, it represents one of several possible combinations of model parameters that could be used to fit simulated to observed streamflow values. The weight-of-evidence approach utilizes several graphical (qualitative) and quantitative characteristics in optimizing the model fit during the subjective calibration process. Graphical comparisons included arithmetic and logarithmic time series plots of observed and simulated data, flow duration plots of observed and simulated streamflows, and scatter plots of monthly and daily observed and simulated streamflow. Quantitative evaluation of model fit was based on the USGS program HSPF Expert (HSPFEXP; Lumb and others, 1994) output statistics, mean error statistics, along with additional correlation coefficients, including the correlation coefficient, coefficient of determination, and model fit efficiency.

The correlation coefficient, $r$, was calculated as

$$
r=\frac{\sum_{i=1}^{N}\left(q_{o}-\overline{q_{o}}\right) \times\left(q_{s}-\overline{q_{s}}\right)}{\sqrt{\sum_{i=1}^{N}\left(q_{o}-\overline{q_{o}}\right)^{2} \times \sum_{i=1}^{N}\left(q_{s}-\overline{q_{s}}\right)^{2}}}
$$

where

$\mathrm{q}_{\mathrm{o}}$ is observed flow for given time step,

$\frac{\mathrm{q}_{0}}{\mathrm{q}_{\mathrm{o}}}$ is average observed flow for given time step,

$\mathrm{q}_{\mathrm{s}}$ is simulated flow for given time step,

$\frac{\mathrm{q}_{\mathrm{s}}}{\mathrm{q}_{\mathrm{s}}}$ is average simulated flow for given time step. 


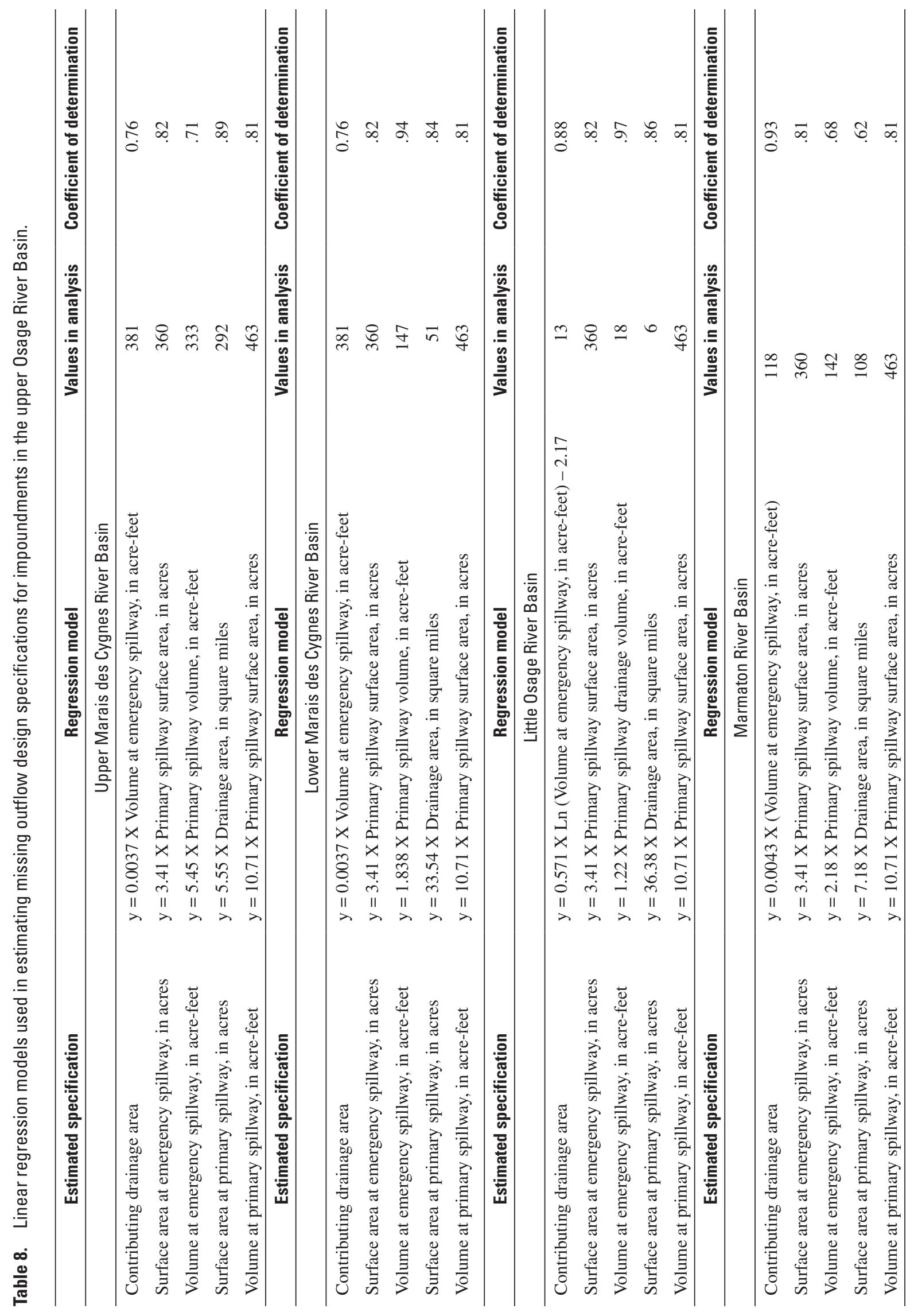


Table 9. Relation between detention volume and median dam height used in estimating missing impoundment design specifications for the upper Osage River Basin models $(n=664)$.

$[<$, less than; $>$, greater than $]$

\begin{tabular}{cc}
\hline Detention volume, in acre feet & Median dam height, in feet \\
\hline$<200$ & 23 \\
$200-500$ & 29 \\
$500-1,000$ & 33 \\
$>1,000$ & 42 \\
\hline
\end{tabular}

The coefficient of determination $\left(\mathrm{r}^{2}\right)$ is calculated simply as the square of the correlation coefficient (r). The coefficient of efficiency, $E$, (Nash and Suttcliffe, 1970) has been widely used to evaluate the performance of hydrologic models and is defined as

$$
E=1-\frac{\sum_{t=1}^{T}\left(q_{o}^{t}-\overline{q_{s}^{t}}\right)^{2}}{\sum_{t=1}^{T}\left(q_{o}^{t}-\overline{q_{o}}\right)^{2}}
$$

Where $\mathrm{q}_{\mathrm{o}}$ and $\mathrm{q}_{\mathrm{s}}$ are defined as above for each time step $t$.

The coefficient ranges from minus infinity (poor model) to 1.0 (perfect model). Legates and McCabe (1999) state that "The coefficient of efficiency represents an improvement over the Coefficient of Determination for model evaluation purposes because it is sensitive to differences in observed and model simulated means and variances...". Donigian (2002) characterize model "goodness of fit" based on the percent difference in observed and simulated total runoff volume and the coefficient of determination values computed from daily and monthly observed and simulated streamflow values (table 11).

Calibration and validation also were conducted at two sites (Marais des Cygnes River near Reading, Kansas and Dragoon Creek near Burlingame, Kansas) upstream from U.S. Army Corps of Engineers reservoirs, although these areas were not used in the current (2005) and proposed model scenarios because observed reservoir outflows were available and used instead. These two basins were calibrated and validated for the development of parameters in the pre-settlement scenario and to confirm spatial trends in model parameters; that is, to confirm differences in parameter values with the size and location of the simulated subbasins.

Coon and Johnson (2005) and Laroche and others (1996) provide a list of parameters that were found to most strongly affect the hydrologic response of a HSPF model; that is, those parameters to which the model was most sensitive. These include the ground-water recession constant (AGWRC), which controls the rate at which ground water drains from the land); infiltration equation exponent (INFEXP), which controls the rate of infiltration decrease as a function of increasing soil moisture; the ratio of maximum to mean infiltration capacities (INFILD); index to mean soil-infiltration rate (INFILT); interflow-inflow parameter (INTFW), which controls the amount of infiltrated water that becomes shallow subsurface flow; interflow recession constant (IRC); ground-water flow parameter used to describe non-linear groundwater recession rate (KVARY); lower zone evapotranspiration (LZETP), which represents the density of deep rooted vegetation that conveys water from the unsaturated zone to the atmosphere; lowerzone nominal soil moisture storage (LZSN), which is an index to the soil-moisture holding capacity of the unsaturated zone); and upper-zone nominal storage (UZSN), which is an index to the soil-moisture holding capacity of depressions and the surface soil layer). For this study, AGWRC, INFILT, INTFW, LZSN, LZETP, and UZSN were the parameters for which the simulations were observed to be most sensitive. Parameters of lesser sensitivity included IRC and KVARY.

The period of streamflow record used for calibration varied for the 15 streamflow-gaging station locations used in the calibration of the upper Osage River Basin models (eight gages used in the Marais des Cygnes, one in the Little Osage, five in the Marmaton, and one in the Osage River Basin; table 12). Whereas 10 years (1995-2004 water years) of precipitation and temperature data were available for calibration and validation, the actual period of calibration and validation for a particular streamflow-gaging station location varied and was limited by the available observed streamflow record. Whereas years 1995 through 2003 generally were used for calibration of the Marais des Cygnes and Little Osage River models, the calibration period at the Marmaton River streamflow-gaging stations only was about 4 years (generally from 2001 through 2004; table 12) because of limited streamflow record.

Calibration was begun at headwater streamflow-gaging station locations, and then conducted at downstream gages within each model basin. Initial parameter values for the headwater streamflow-gaging station sites were obtained from guidance provided from the U.S. Environmental Protection Agency (2000). This publication provides guidelines for both the typical and maximum working ranges of HSPF model parameters. The parameters generated as a result of these calibrations subsequently were used as the initial estimate of parameter values at downstream locations and adjusted as necessary within the specified working ranges.

Version 2.4 of the USGS software HSPFEXP (Lumb and others, 1994; available at USGS, 2005d) was used for calibrating gaged Marais des Cygnes River headwater basins. Further calibration of these and remaining basins was conducted using WinHSPF (version 2.3; packaged with BASINS 3.1, U.S. Environmental Protection Agency, 2005a) and calculated summary statistics. The use of HSPFEXP was limited to select headwater basins as it utilizes a version of HSPF with a 200 operations limit that was incapable of running the larger models, whereas WinHSPF has a 500 operations limit with greater model size capability. The number of operations in a model is determined by the number of RCHRESs, along with the number of pervious and impervious land-cover types represented in the model. The use of WinHSPF also allowed for a recommended model initialization or "start-up" period (GutierrezMagness, 2005) before determining the summary statistics. 
Table 10. Impoundment outflow characteristics used for estimating the elevation difference between primary and emergency spillway, primary spillway culvert diameter, and emergency spillway width in the in the 10-, 50-, and 90th-percentile design scenarios.

$[<$, less than; >, greater than]

\begin{tabular}{cccc}
\hline \multirow{2}{*}{$\begin{array}{c}\text { Detention volume, } \\
\text { in acre-feet }\end{array}$} & \multicolumn{2}{c}{ Elevation difference between primary and emergency spillway, in feet } \\
\cline { 2 - 4 }$<100$ & $\mathbf{1 0}^{\text {th }}$ Percentile design & $\mathbf{5 0}^{\text {th }}$ Percentile design & $\mathbf{9 0}^{\text {th }}$ Percentile design \\
\hline $100-500$ & 2 & 6 & 8 \\
$>500$ & 3 & 10 & 12 \\
\end{tabular}

\begin{tabular}{|c|c|c|c|}
\hline \multirow{2}{*}{$\begin{array}{l}\text { Contributing drainage area, } \\
\text { in square miles }\end{array}$} & \multicolumn{3}{|c|}{ Primary spillway culvert diameter, in inches } \\
\hline & $10^{\text {th }}$ Percentile design & $50^{\text {th }}$ Percentile design & $90^{\text {th }}$ Percentile design \\
\hline$<2$ & 18 & 18 & 24 \\
\hline $2-4$ & 18 & 24 & 30 \\
\hline$>4-8$ & 24 & 30 & 36 \\
\hline$>8-12$ & 30 & 36 & 48 \\
\hline$>12$ & 36 & 48 & 48 \\
\hline
\end{tabular}

\begin{tabular}{cccc}
\hline \multirow{2}{*}{$\begin{array}{c}\text { Contributing drainage area, } \\
\text { in square miles }\end{array}$} & \multicolumn{3}{c}{ Emergency spillway width, in feet } \\
\cline { 2 - 4 } & $\mathbf{1 0}^{\text {th }}$ Percentile design & $\mathbf{5 0}^{\text {th }}$ percentile design & $\mathbf{9 0}^{\text {th }}$ percentile design \\
\hline$<0.65$ & 30 & 55 & 105 \\
$0.65-5.0$ & 40 & 70 & 120 \\
$>5.0$ & 275 & 275 & 275 \\
\hline
\end{tabular}

During the HSPF calibration procedure it became evident that the largest discrepancies between observed and simulated streamflows occurred with extreme flows for storm peak flows and low flows (figs. 21, 22). Observed hourly flows in the upper Osage River Basin varied from zero to nearly 63,000 $\mathrm{ft}^{3} / \mathrm{s}$ during water years 1995-2004. The study objectives were such that simulating the full range of flows was of interest and, therefore, no more or less emphasis was placed on calibrating one range of flows at the expense of another. Logarithmic plots of daily observed and simulated streamflows (fig. 21) indicated that timing of simulated runoff generally matched well with observed flows, and that no consistent biases were observed with runoff event size or timing.

The most obvious differences between observed and simulated streamflows in the flow duration plots was an overestimation of low flows at select stations (fig. 22). When attempting to calibrate to streamflows that may reach zero flow, even absolute errors of less than $1 \mathrm{ft}^{3} / \mathrm{s}$ can result in substantial percent differences. One possible cause for the overestimation of low flows was the possible erroneous simulation of impoundment outflows. Minor absolute outflow errors of less than $1 \mathrm{ft}^{3} / \mathrm{s}$, when compounded over 10's or 100 's of impoundments in a basin, may account for the over- estimated flows. A consistent and cumulative bias such as this would become obvious when comparing low-flow statistics for basins with (Marais des Cygnes River and Marmaton River Basins) and without (Little Osage River Basin) a substantial numbers of impoundments. The calibration results (table 12), however, did not indicate that substantial differences in the 50 -percent lowest flows existed between basins. A comparison of the error in the 50-percent lowest flows at the Marmaton River near Nevada, Missouri, for a current, no impoundment (180 percent) and current, with impoundment scenario (203 percent) indicated similarities in errors despite the addition of impoundments. Adjustment of the parameters controlling low-flow characteristics within recommended ranges (U.S. Environmental Protection Agency, 2000) failed to substantially reduce the low-flow errors, and any minor benefits gained for this specific model fit statistic came at the expense of overall model fit statistics.

The total volume errors in the calibration summary statistics were within recommended targets, but other statistics confirmed discrepancies between observed and simulated extreme flows. Using a target of 10 percent for the error between total observed and simulated runoff volume, all calibrated scenarios were within the limits of a "very good" calibra- 


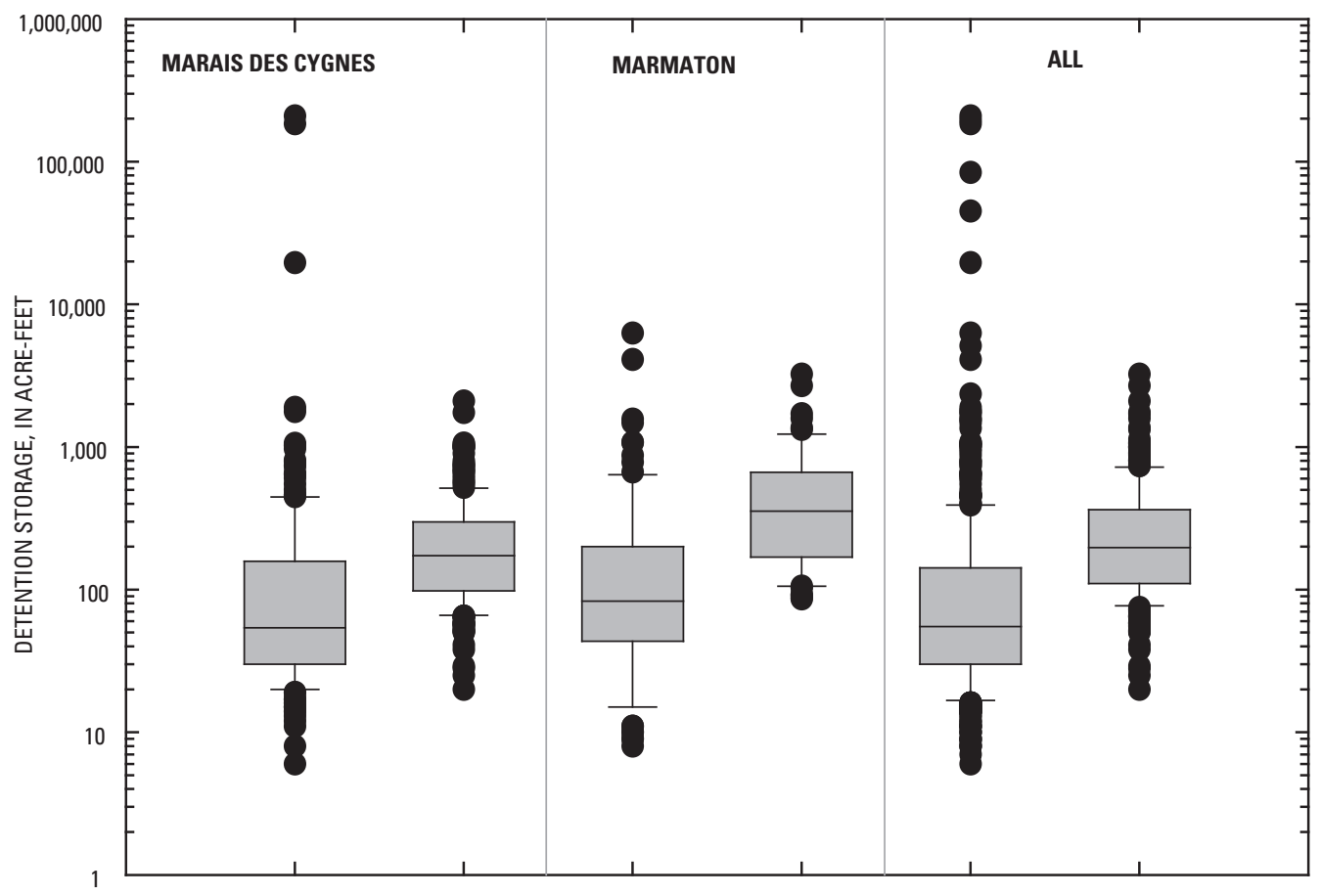

EXPLANATION

Percentile-Percentage of analyses equal to or less than indicated values
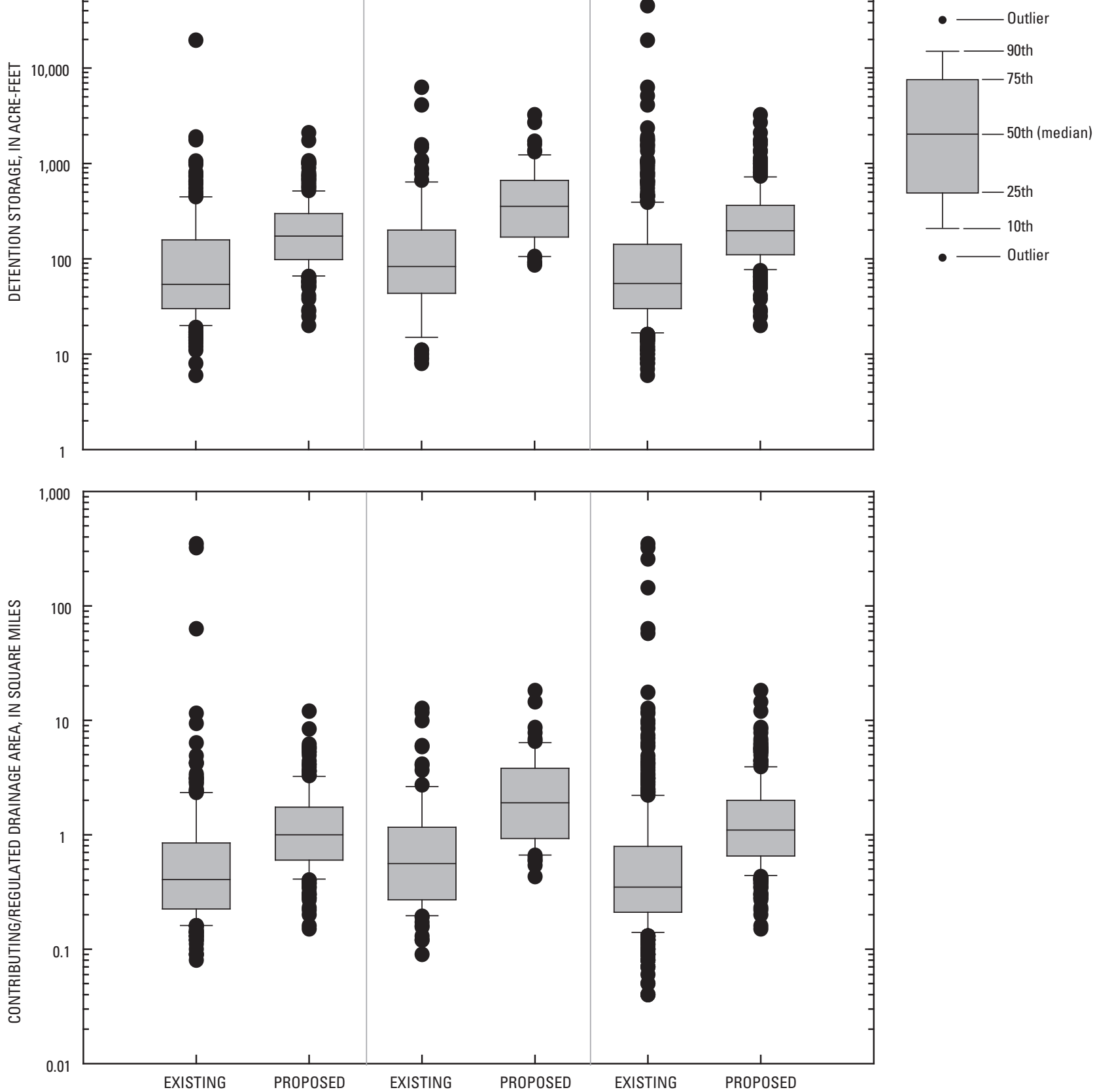

Figure 20. Existing and proposed impoundment detention volume and contributing drainage area for the Marais des Cygnes, Marmaton, and entire upper Osage River basins. 
Table 11. Criteria for determining Hydrologic Simulation Program-FORTRAN calibration and validation goodness of fit (modified from Donigian, 2002).

$[<$, less than; $>$, greater than $]$

\begin{tabular}{l|c|c|c}
\hline & Very Good & Good & Fair \\
\hline \multicolumn{4}{c}{ Percent difference between observed and simulated monthly } \\
or annual values \\
\hline Total runoff volume & $<10$ & $10-15$ & $15-25$ \\
\hline \multicolumn{4}{c}{ Coefficient of determination } \\
\hline Daily streamflow & $>0.80$ & $0.70-0.80$ & $0.60-0.70$ \\
\hline Monthly streamflow & $>.85$ & $.75-.85$ & $.65-.75$ \\
\hline
\end{tabular}

tion (tables 11, 12). As indicated in the flow-duration curves, however, the error in "50-percent lowest flows" exceeded the error target of 15 percent at all sites. The storm peaks volume error also exceeded the target of 15 percent at 11 of 15 sites (table 12). The exceptions were at streamflow-gaging station sites near the Kansas-Missouri state line including the Marais des Cygnes River at Lacygne, Kansas (station 06915800; fig. 12); Marais des Cygnes River near Kansas-Missouri state line, Kansas (station 06916600; fig. 12); Little Osage River at Fulton, Kansas (station 06917000; fig. 13); and the Marmaton River near Nevada, Missouri (station 06918060; fig. 13). In some cases, the magnitude of the peak was similar, but the timing was such that the daily volume differences exceeded the threshold. Whereas the storm peaks volume typically was underestimated, the storm volume and summer storm volume typically were within the 15 percent error target (table 12).

Using the overall model fit summary statistics including the coefficient of determination $\left(\mathrm{r}^{2}\right)$, and model fit efficiency $(E)$, the daily flow values were rated "very good" at five sites, "good" at four sites, "fair" at four sites, and "poor" at two locations (Osage River above Schell City, Missouri (USGS streamflow gaging station 06918070); Little Osage River at Fulton, Kansas (USGS streamflow gaging station 06917000; tables 11, 13). Monthly coefficient of determination values were rated "very good" for 14 of the 15 sites and "good" for the remaining site location [East Drywood Creek at Prairie State Park, Missouri (USGS streamflow gaging station 06917630)]. Model fit efficiency, $E$, correlated well with the coefficient of determination, although generally was $0.01-0.02$ units lower. The daily calibration values of model fit efficiency of 0.38 to 0.88 , and monthly calibration values of 0.73 to 0.98 were within published limits of other HSPF studies (Coon and others, 2005).

Every attempt was made during calibration to not only maximize the accuracy of simulated high and low flows, but also to maximize the target hydrograph components (those shown in table 12) and the overall model fit statistics (r, $\mathrm{r}^{2}$, $E$; table 13). During calibration, additional improvements in the hydrograph summary statistics (for example the "lowest 50 percent flows" or "storm peak volumes") were minimal, and any additional improvement in individual hydrograph statistics were at the expense of the overall model fit statistics. The calibration results represent a balance between accurately simulating flow extremes and maximizing the overall model fit statistics.

Most final model parameters (table 14) fell within the typical specified (U.S. Environmental Protection Agency, 2000) working ranges, and all fell within the specified possible ranges. Monthly values were specified for parameters CEPSC (interception storage), NSUR (Manning's n values for overland flow), and LZETP (lower zone evapotranspiration) to simulate changes in vegetation growth and density (table 14). There was an increase in the values of parameters LZSN, INFILT, INTFW, IRC and AGWRC with increasing drainage area. This can be explained by physical changes in the basin associated with increasing drainage area, including more alluvial deposits, along with lower channel gradients.

Validation is the process of obtaining assurance that the calibrated model provides a reasonable representation of the modeled system. This was accomplished by comparing the simulation results to an independent observed data set outside the calibration period. The qualitative and quantitative tools used to assess the quality of the calibration also were used to determine the merit of the validation results. For those streamflow-gaging stations with greater than 5 years of record available during the 1995-2004 water years, 1 year of record was selected for validation. For the calibrated model to reasonably simulate the validation period, it was necessary that the streamflow conditions in the validation period fell within the range of streamflow conditions occurring during the calibration period. Generally, a single "normal" year of record, either at the beginning or end of 1995-2004, was used for validation. Four stations [Marmaton River near Uniontown, Kansas (USGS streamflow gaging station 06917240); East Drywood at Prairie State Park, Missouri; Drywood Creek near Deerfield, Missouri (USGS streamflow gaging station 06917680); and Marmaton River below Nevada, Missouri] had less than 5 years of total record and, therefore, all of the available streamflow record was used in the calibration process.

Five of the 11 sites used in the validation analyses had total volume errors of less than 10 percent (table 12) corresponding to a "very good" classification (table 11). Of the six remaining sites, four were considered "fair" or better and two [Dragoon Creek near Burlingame, Kansas (USGS streamflow gaging station 06911900) and Pottawatomie Creek near Garnett, Kansas (USGS streamflow gaging station 06914000)] were rated "poor". The model-fit parameters at 9 of the 11 sites had a daily $\mathrm{r}^{2}$ of 0.6 or better, placing them in the "fair" or better category, whereas the Little Osage River at Fulton, Kansas, and Osage River above Schell City, Missouri, sites were in the "poor" category (tables 11,13 ). The monthly $\mathrm{r}^{2}$ values were rated "very good" at 10 of 11 validation sites, and the remaining site (Dragoon Creek near Burlingame, Kansas) was rated "good". Validation model fit efficiency values varied from 0.13 to 0.89 for daily values and from 0.67 to 1.00 using monthly flow values (table 13). 


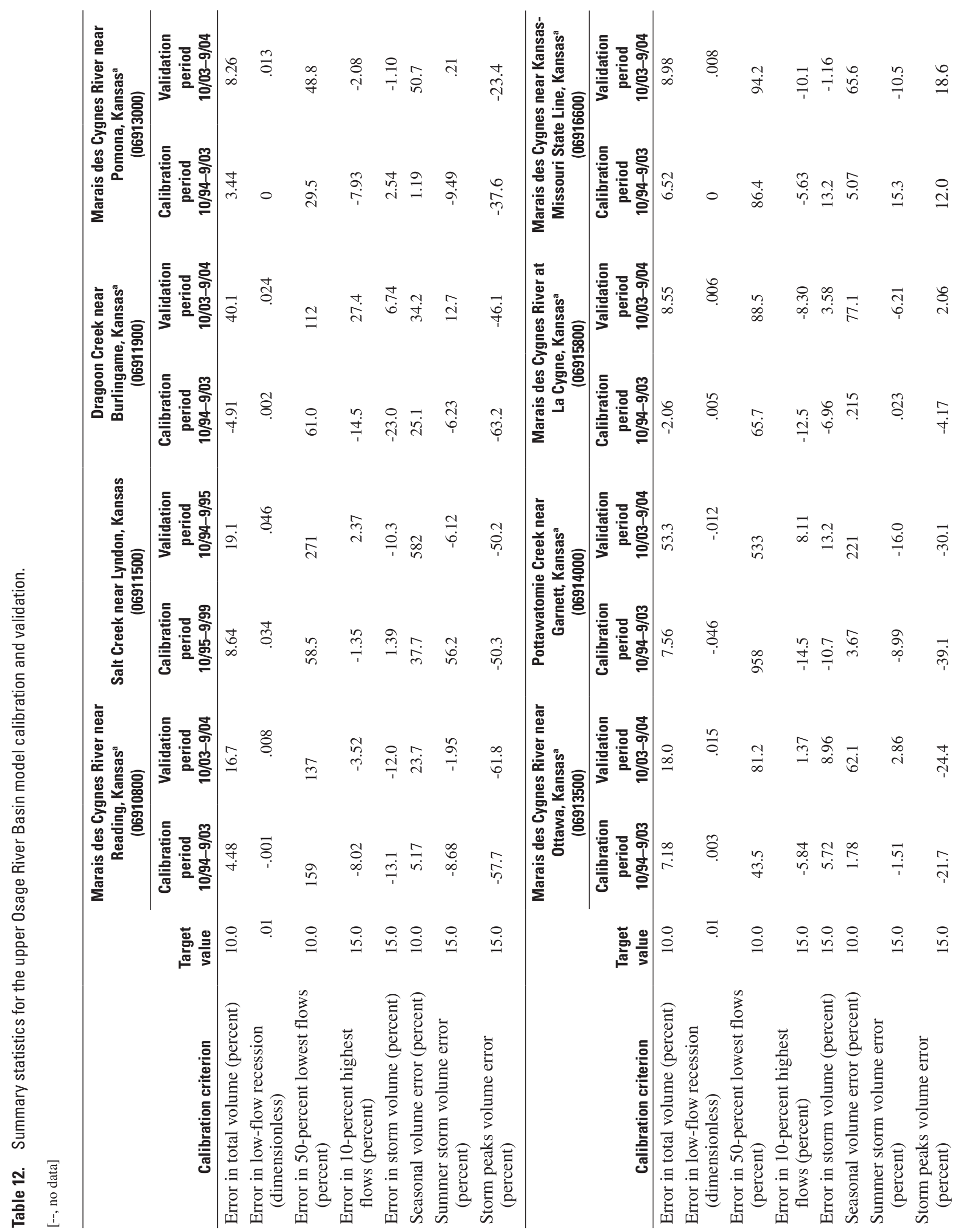




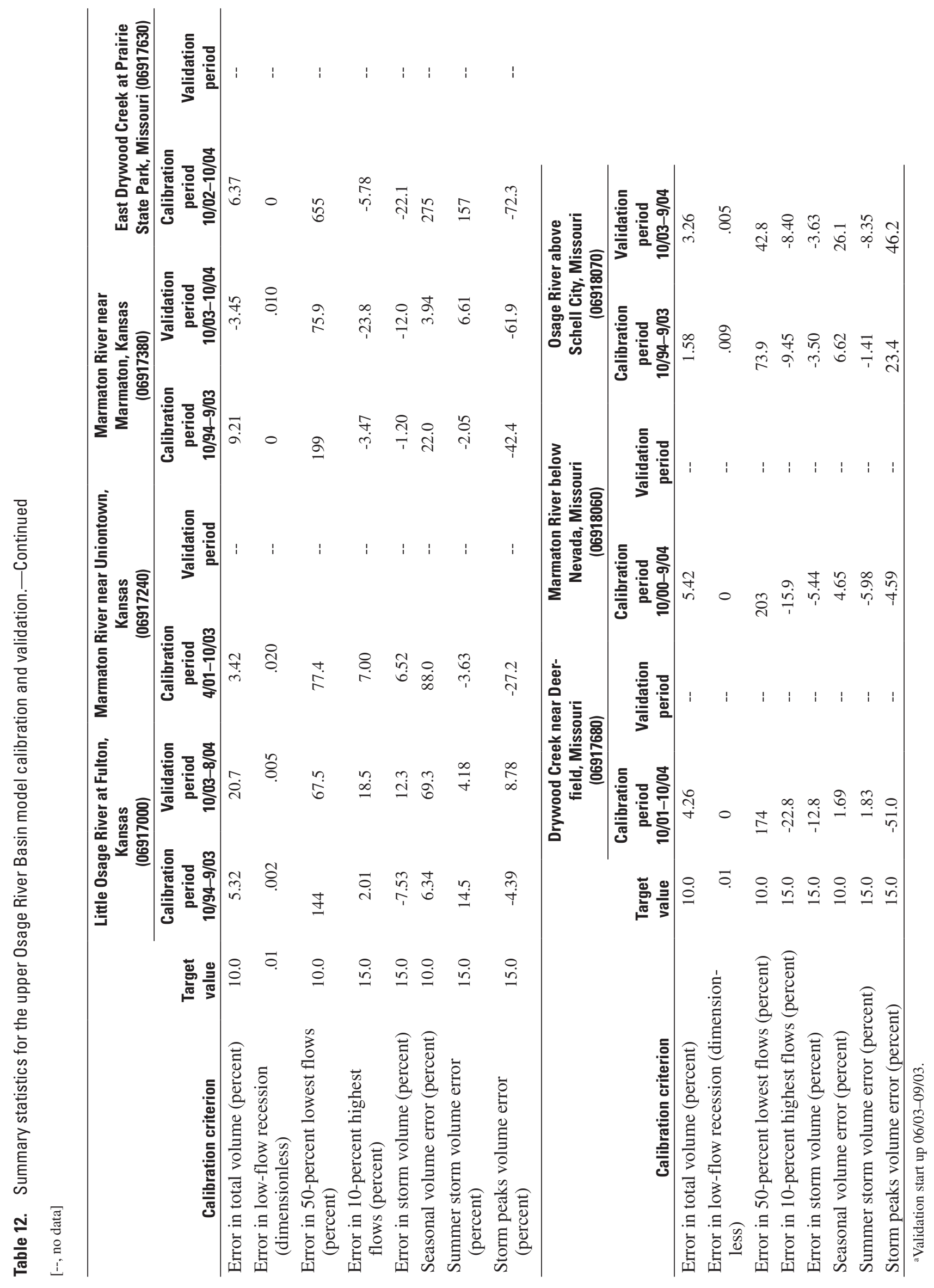



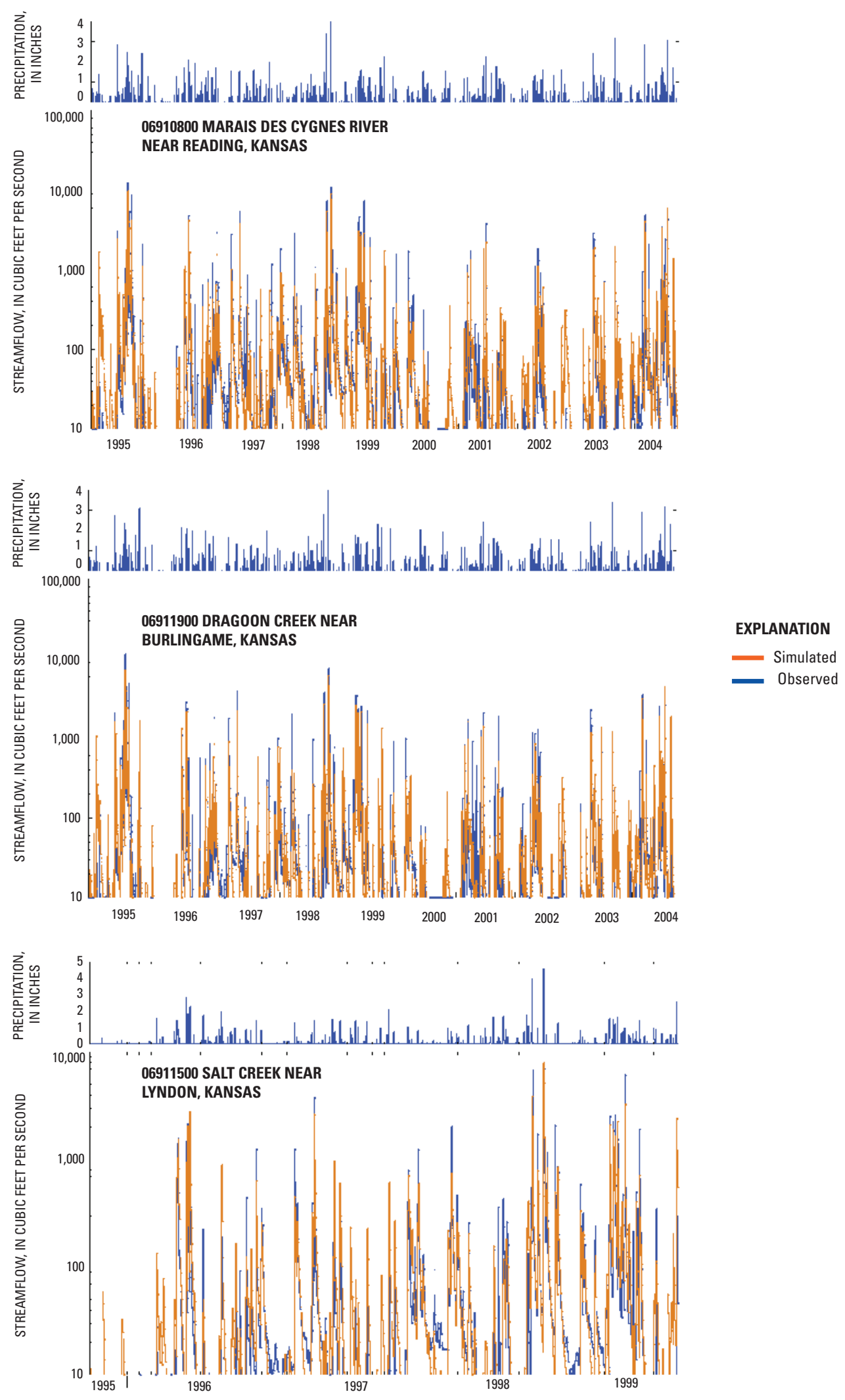

Figure 21. Comparison of simulated and observed daily streamflow at selected streamflow gaging locations in the upper Osage River Basin. 

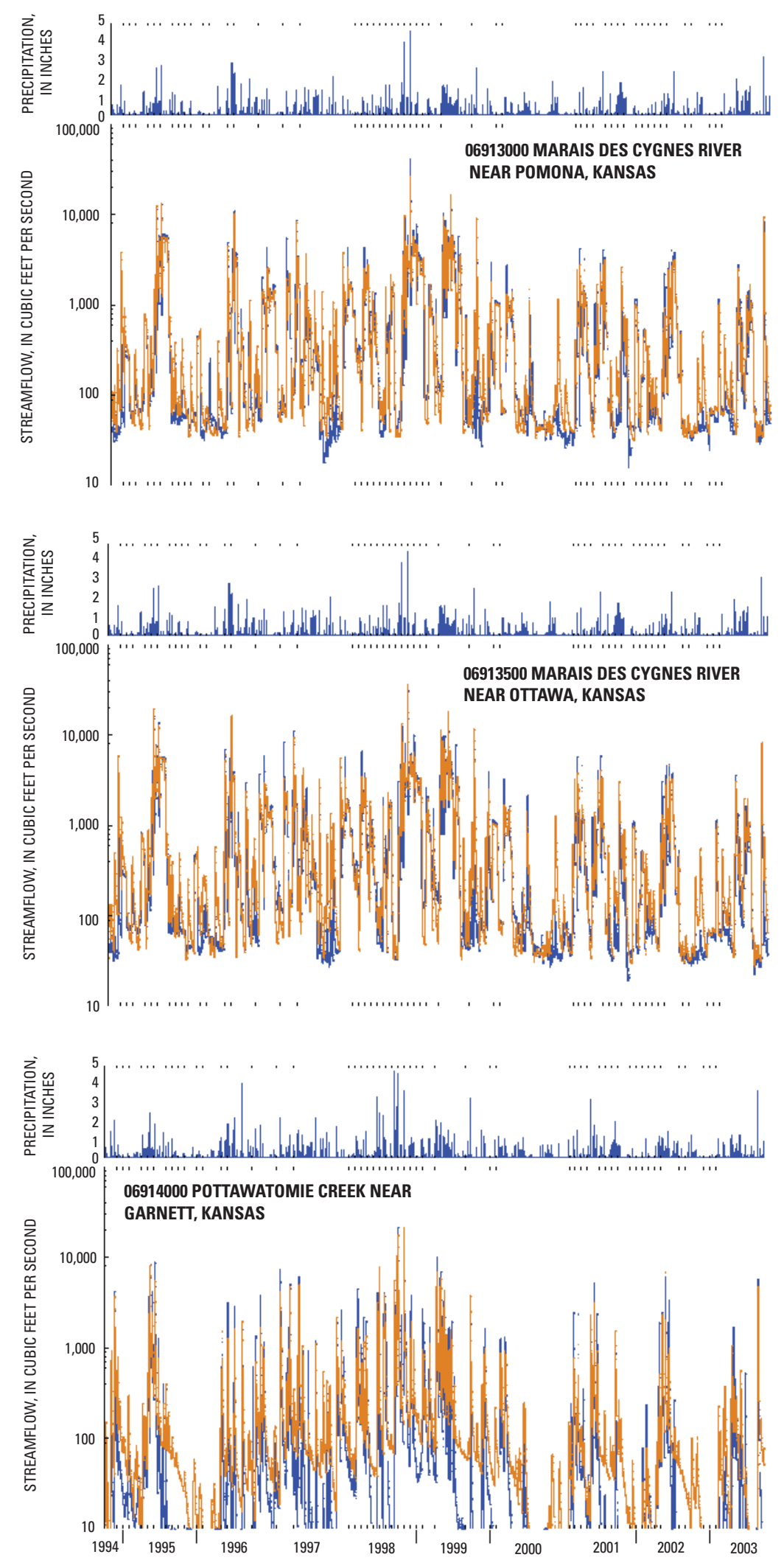

Figure 21. Comparison of simulated and observed daily streamflow at selected streamflow gaging locations in the upper Osage River Basin.-Continued 

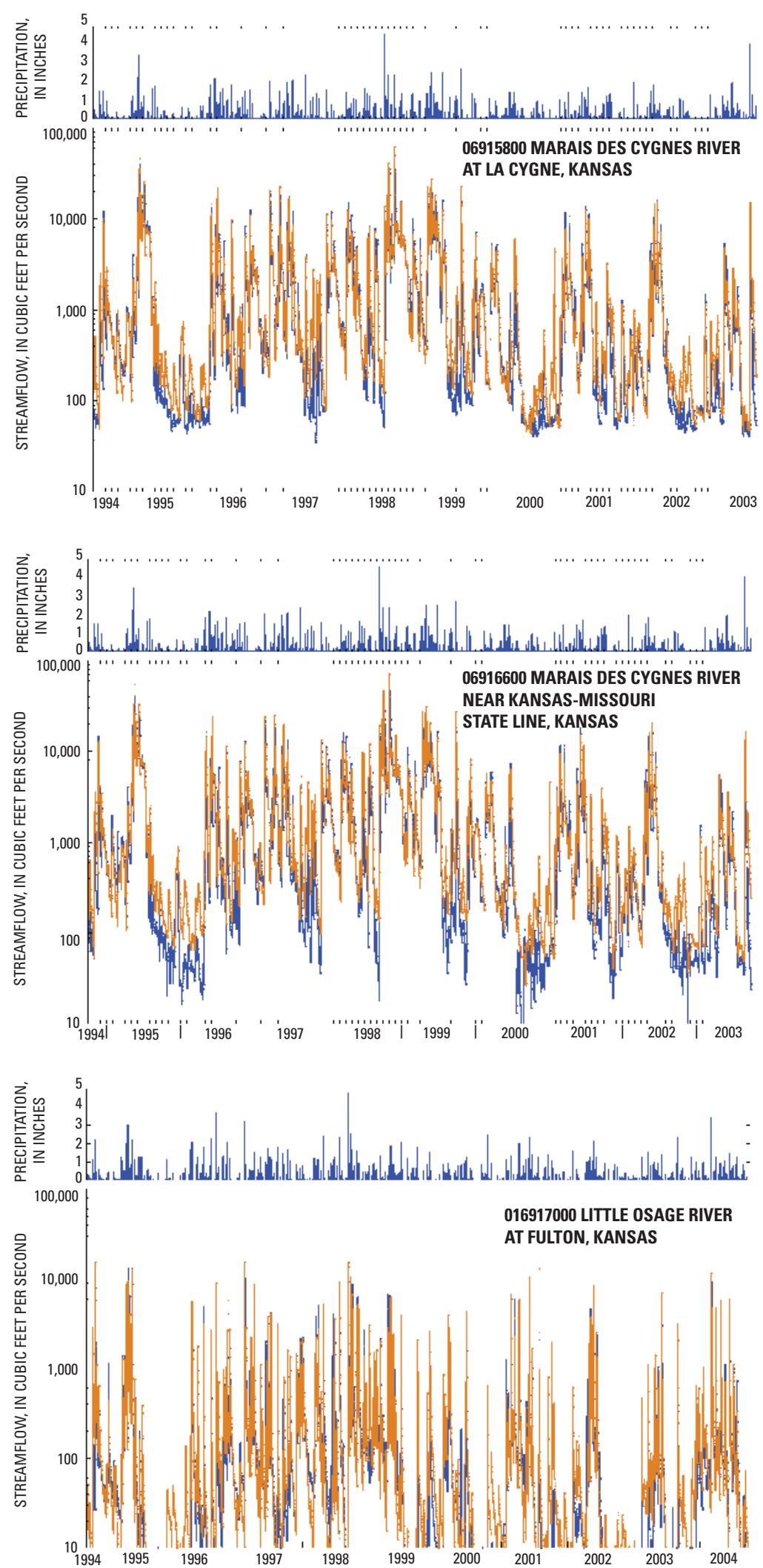

Figure 21. Comparison of simulated and observed daily streamflow at selected streamflow gaging locations in the upper Osage River Basin.-Continued 

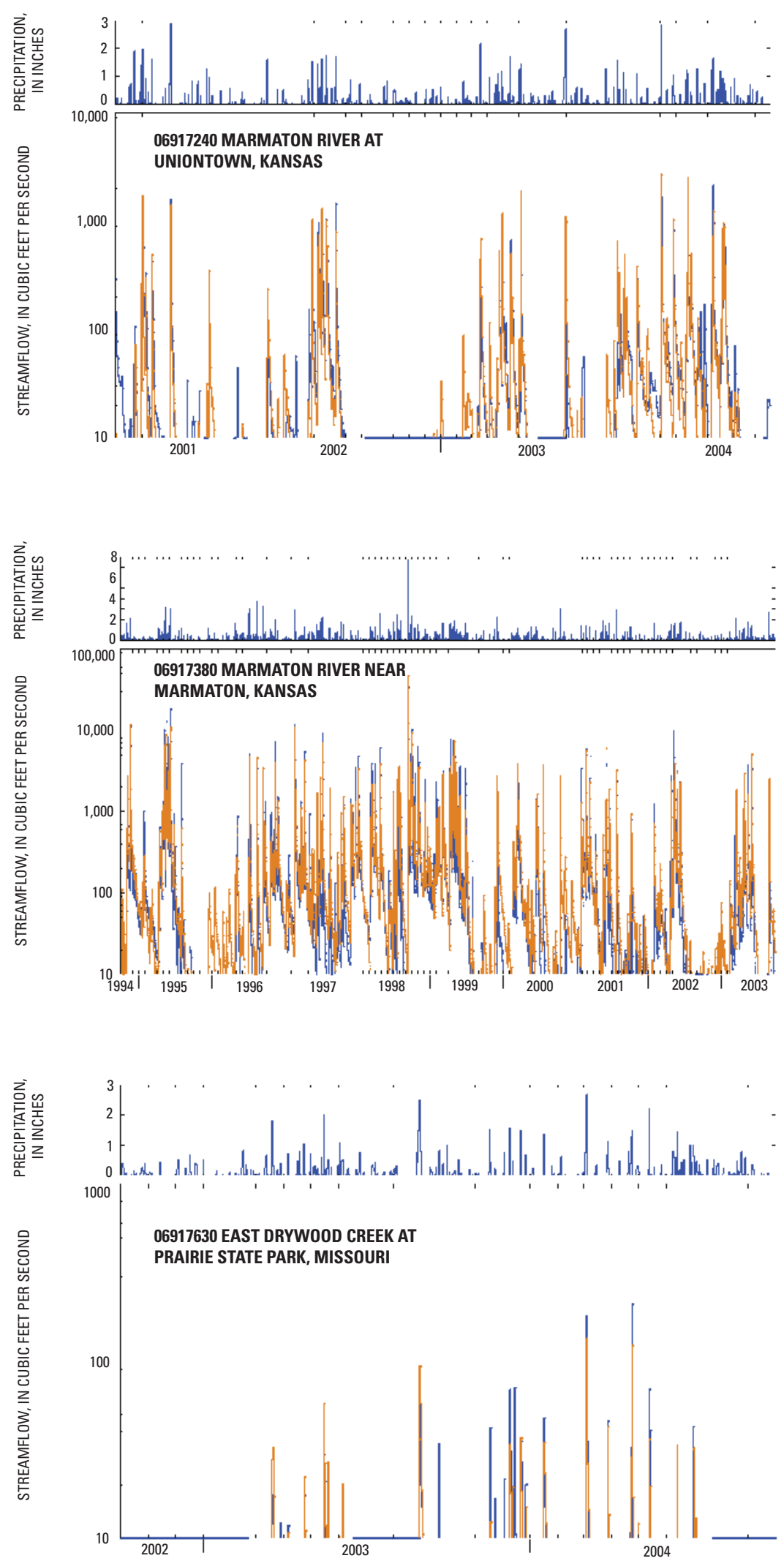

Figure 21. Comparison of simulated and observed daily streamflow at selected streamflow gaging locations in the upper Osage River Basin.-Continued 

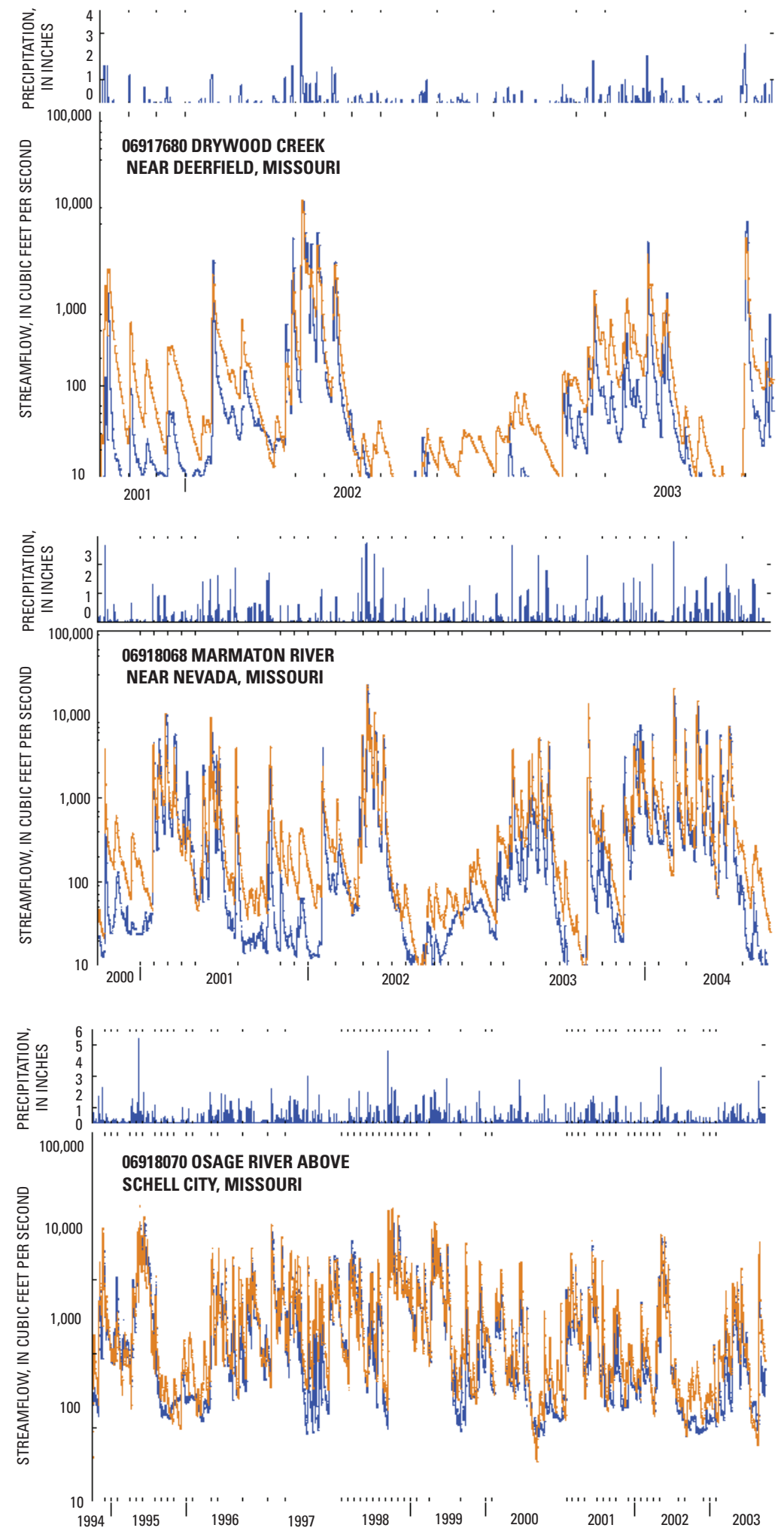

Figure 21. Comparison of simulated and observed daily streamflow at selected streamflow gaging locations in the upper Osage River Basin.-Continued 

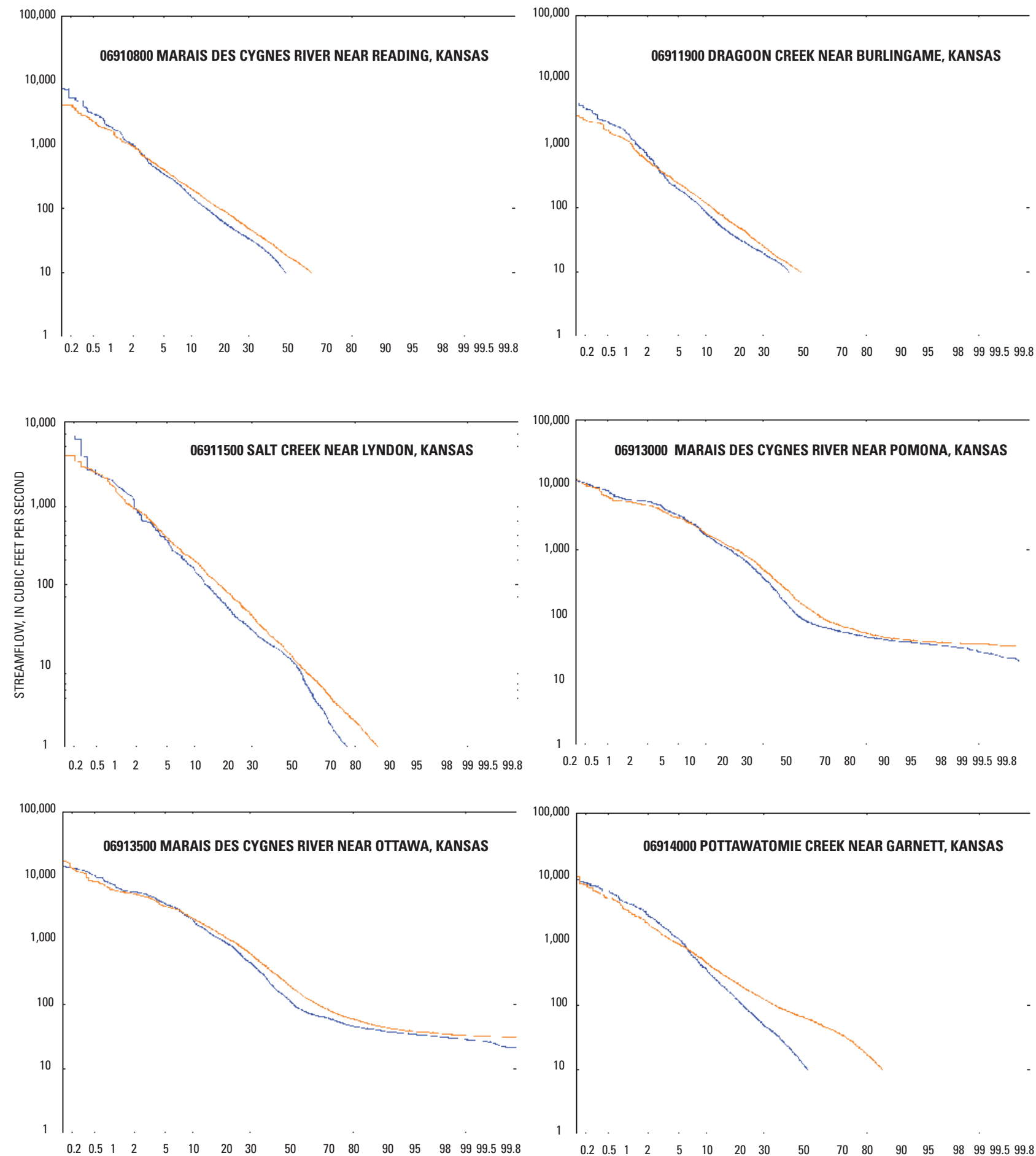
EXCEEDANCE PROBABILITY, IN PERCENT

EXPLANATION

Simulated $\quad$ Observed

Figure 22. Streamflow-duration distributions for simulated and observed daily streamflows in the upper Osage River Basin. 


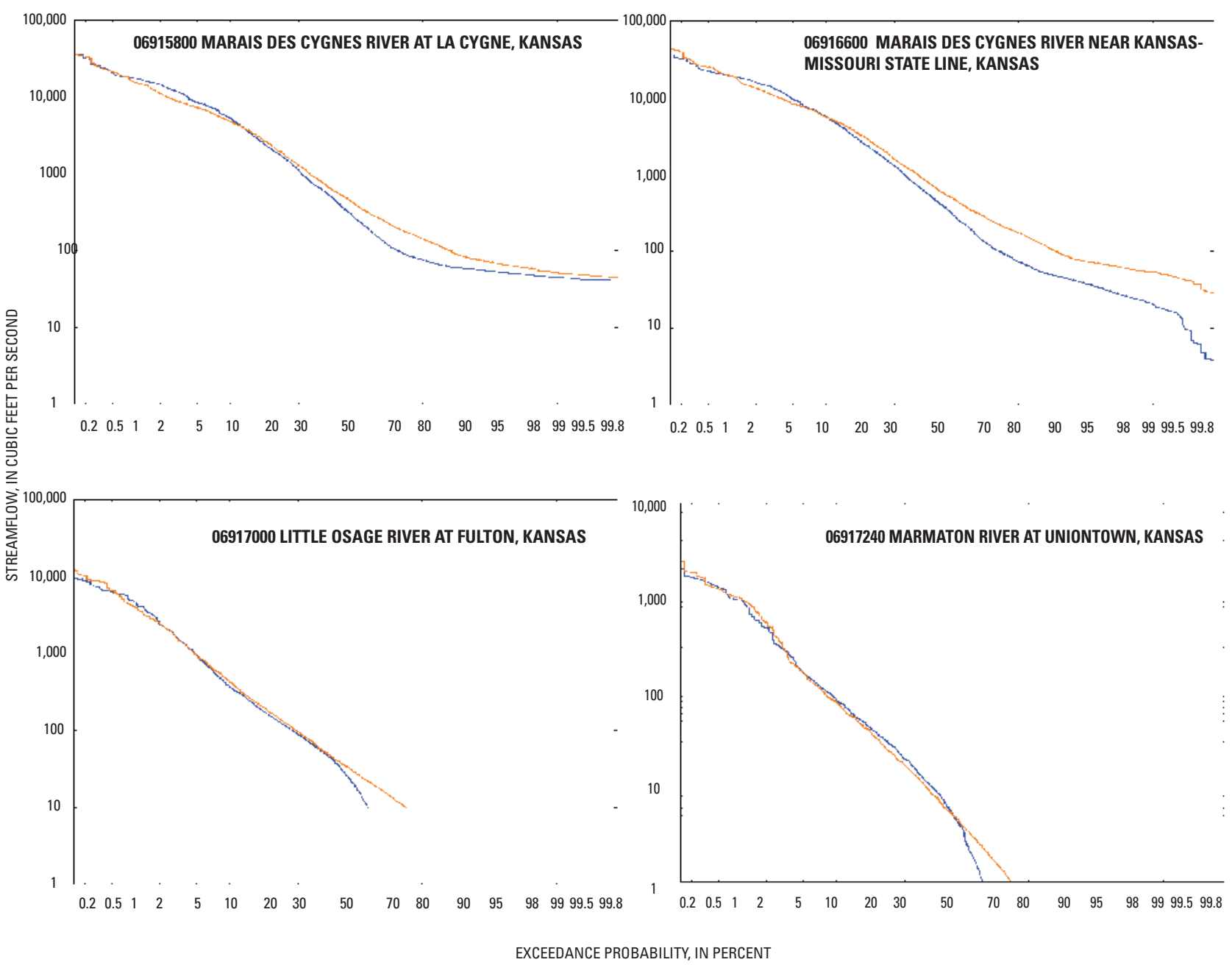

Figure 22. Streamflow-duration distributions for simulated and observed daily streamflows in the upper Osage River Basin.-Continued

\section{Sources of Error and Model Uncertainty}

HSPF is used as a simplified numerical representation of a complex and constantly changing natural system. The majority of calibration targets were within specified target criterion, but any model results will include errors as a result of approximations and simplifications. It is important, therefore, to document potential sources of errors, model uncertainties, and any compensatory measures taken to limit these errors in reported results.

Sources of error in the HSPF application included possible non-reported withdrawals; limited spatial definition of input data time series (precipitation, temperature, evapotranspiration, streamflow), lack of temporal changes in land-cover information, initial estimates of hydrologic quantities, and estimates of impoundment design specifications and operation. All reported withdrawals in each of the model basins were included in the simulations; however, the likelihood of non-reported withdrawals remains a potential source of the discrepancy detected between simulated and observed low flows. During base-flow periods, even small (less than $1 \mathrm{ft}^{3} / \mathrm{s}$ ) errors in a non-reported withdrawal could cause simulated flows to be substantially different than observed flows, and at these low flows small absolute differences can result in substantial percent differences in the reported calibration results. In such cases, large discrepancies can result between simulated and observed values because of inaccurate input data, despite a reasonable representation of hydrologic processes by the model.

Precipitation likely is the most important input data source in the hydrologic model and limitations in representing the spatial and temporal variability of precipitation may be a primary source of error. Hourly precipitation time series were developed for meteorological segments covering tens or hundreds of square miles, and these time series were developed using data from some precipitation stations that are located outside the segment and were derived from disaggregated daily precipitation data. Gutiérrez-Magness and McCuen (2004) and Gutiérrez-Magness (2005) evaluated several methods used to disaggregate daily precipitation to 


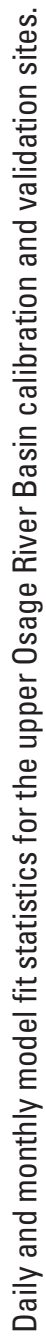

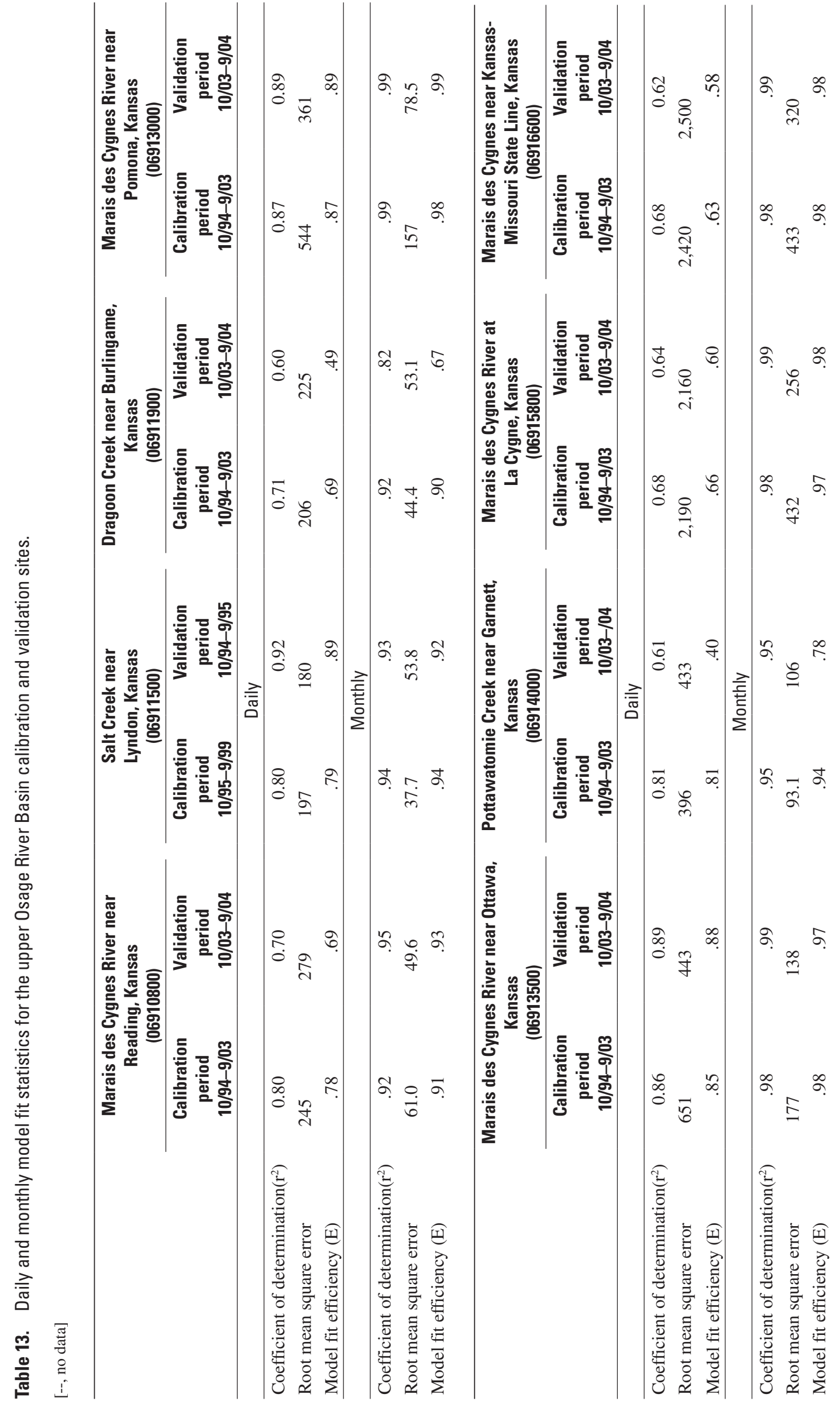



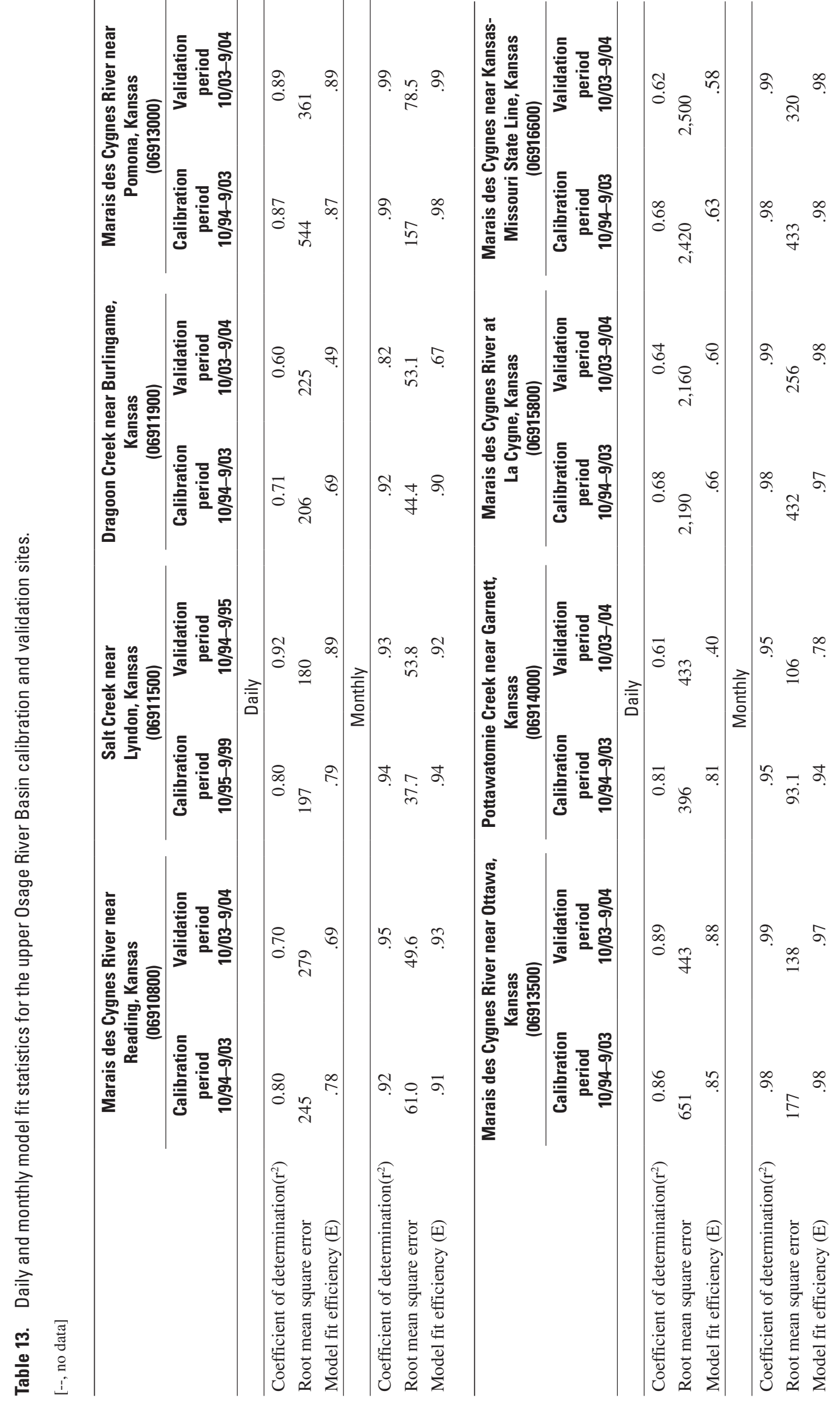




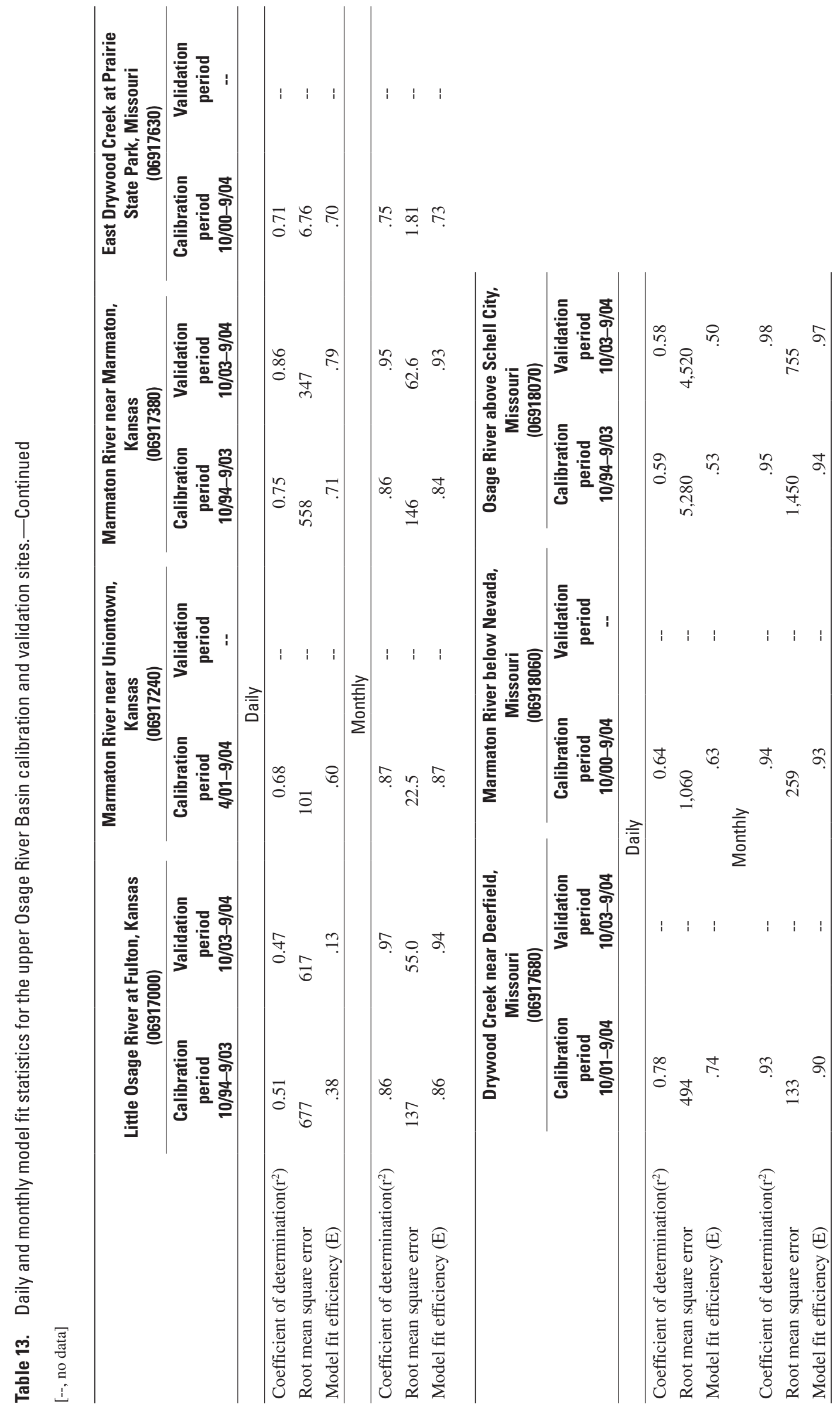




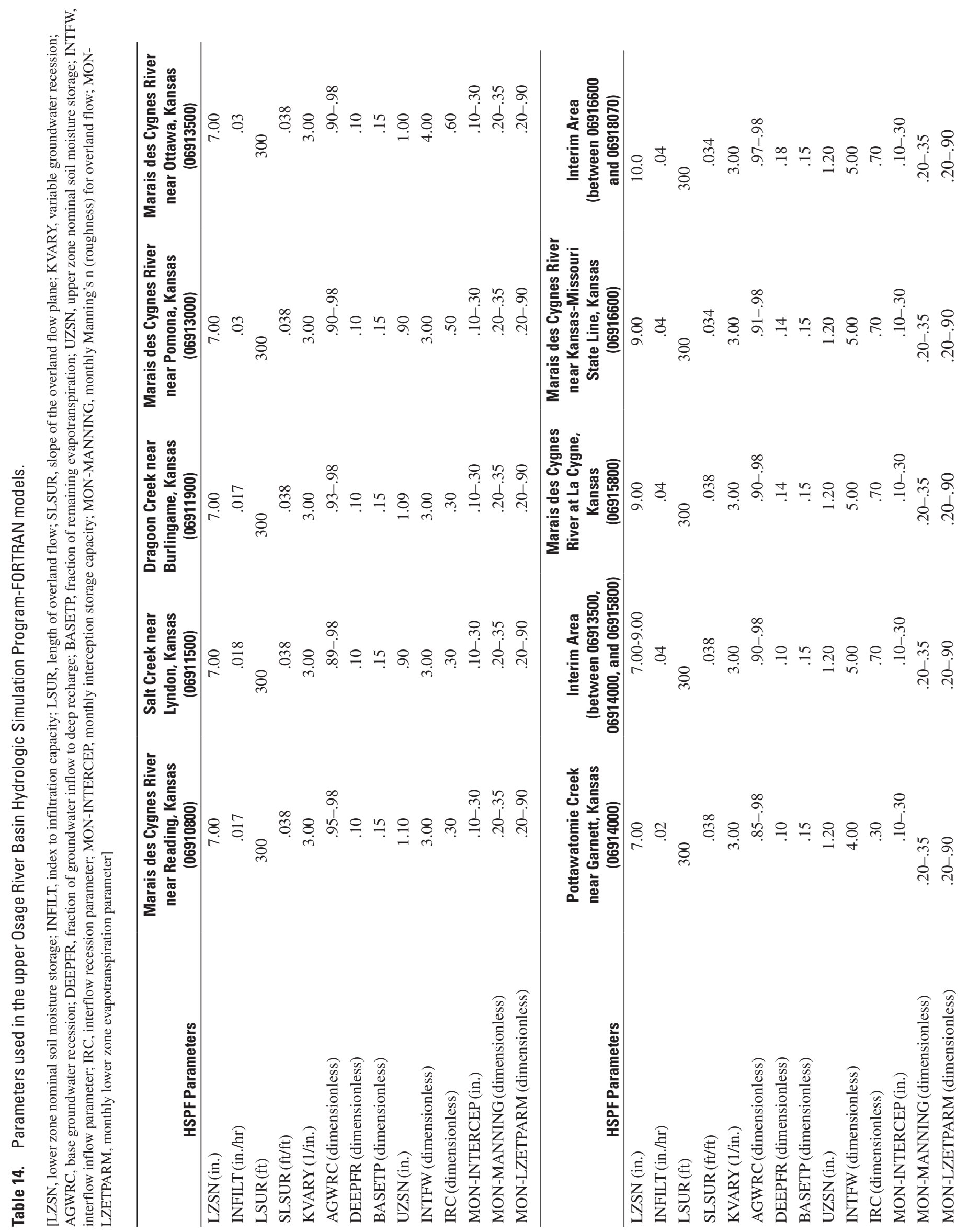




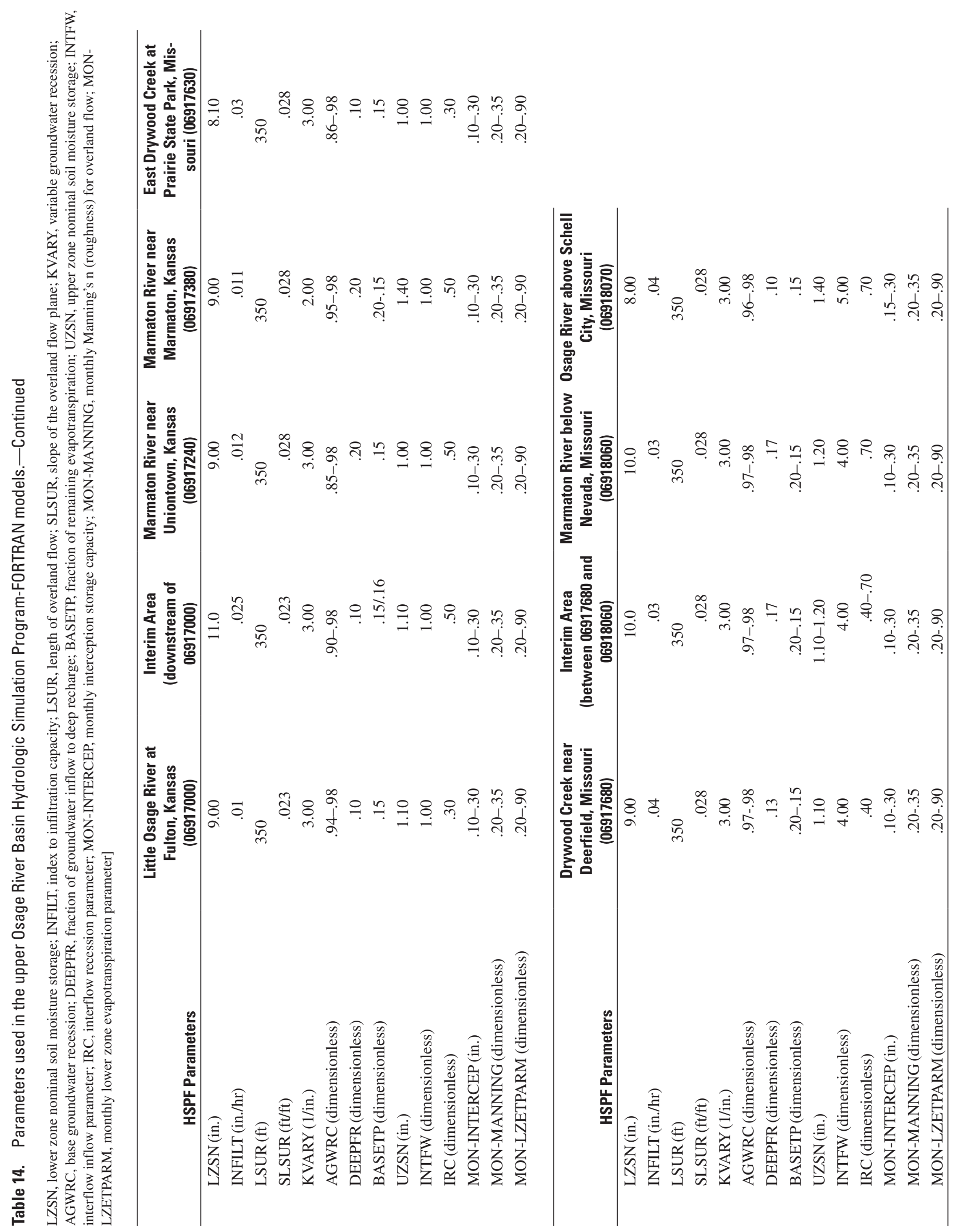


hourly values, and determined limitations with all methods to accurately determine the distribution and intensity of rainfall events. Although several hourly precipitation gages were located in the basin, these primarily were used for disaggregation of daily precipitation values. Maximum and minimum daily temperature information also was estimated for meteorological segments based on stations that may not be located within these segments. The subsequent hourly temperature distributions were estimated based on a sinusoidal relation fit to these two daily extremes. As hourly potential evapotranspiration data were determined from temperature data, these input time series also were subject to the same sources of error as temperature. The USGS hourly streamflow time series used in calibration and validation were estimated using a stage-discharge relation developed from instantaneous measurements. Typically, instantaneous streamflow measurements have associated errors of 5 to 8 percent; this error can account for some of the differences computed between observed and simulated hourly streamflow.

The land-cover information in the current scenarios was developed from 1992-1995 data, and may not fully represent conditions during the entire study period (1995 through 2004). The land-cover information also was assumed to be static during the 10-year simulation period. Land-cover information for the pre-development scenarios was estimated using simplified constructed maps of historical land-cover information with corresponding parameter characteristics obtained from current calibrations. The historical wetland area was estimated using the 1995 wetland area and, therefore, the historical wetland area may be under-represented. The current channel geometry was used in developing and comparing the pre-settlement, current, and proposed hydrologic conditions. Anthropogenic alterations of the Little Osage and Marmaton River channels have been minimal; however, there have been extensive modifications to the lower Marais des Cygnes River channel that could affect such comparisons.

Errors in model scenarios can result from erroneous initial condition estimates. Whereas certain parameters may reach equilibration within a few model iterations (hours), others may take weeks or months to equilibrate. Two methods were employed to minimize the effects of erroneous initial conditions in the study simulations. The first was to incorporate a model "start-up" period before the simulation period of interest. This requires the availability of additional meteorological data outside the simulated period of interest. Gutierrez-Magness (2005) determined that by incorporating a start-up period of "about a year" before the calibration or validation period that associated errors were minimized. Available streamflow and meteorologic data allowed for an approximate 3-month start-up period in the validation record at select gaging stations. A second approach used in minimizing errors attributable to initial parameter conditions was to use computed ending values for the specified initial conditions as a starting point for subsequent simulation runs in an iterative estimate approach.
The number, distribution, and design specifications of impoundments were additional potential sources of error in the numerical simulations. The estimate of reservoir numbers in the basin provided by the National Inventory of Dams (U.S. Army Corps of Engineers, 2005) augmented with state-permitted impoundments (Joe File, Kansas Department of Agriculture, Division of Water Resources, written commun., 2005) may underestimate the total number of impoundments in the basin. Smith and others (2002) determined that the National Inventory of Dams underestimated the number of impoundments in selected basins when compared to Geographic Information System analyses of the areas. Therefore, simulations of the possible effects of impoundments used in this study are likely conservative estimates of the actual effects of impoundments on streamflows in the upper Osage River Basin. The impoundment location information was accurate enough to assign an impoundment to a RCHRES, but it was not possible to determine the actual overlap of contributing drainage area, or "chaining," between impoundments. All impoundments were assumed to have independent contributing drainage areas unless the total drainage area associated with the impoundments in a RCHRES exceeded the total drainage area of that RCHRES. In this case, the reservoirs were "chained" until the amount of regulated area was within the total RCHRES area. Whereas reservoir storage was assumed to be static, in actuality, the elevation-storage and elevation-area relations of impoundments are constantly changing as a result of sedimentation. The effects of possible errors resulting from erroneous design specification estimates was quantified using multiple scenario runs under a range of varying design specifications $\left(10^{\text {th }}-, 50^{\text {th }}\right.$, and $90^{\text {th }}$-percentiles in input design characteristics representing varying levels of reservoir detention as described in the "Stage-area and Stage-volume outflow relations" section of this report) from the distribution of possible design variables including spillway width, culvert diameter, and primarysecondary spillway elevation differences.

Uncertainty in the model results differs with the time interval, hydrologic characteristic of interest, and reporting location. Results for longer duration times will be more accurate than for shorter times, and, therefore, the 10-year, annual, or monthly simulation results are more accurate than daily or hourly values as various sources of errors, rather than compounding, would tend to "cancel out" over longer times. The calibration results indicated that the peak streamflow simulations were most accurate near the Kansas-Missouri state line (table 12) in each primary river basin and, therefore, summarizations of high flows are limited to these reporting locations.

Techniques used to limit the uncertainty in model results, particularly in simulated low flows, included adjusting simulated time series with observed flows at gaged reporting locations, and presenting results in terms of relative differences between current-simulated (or observed, if streamflow data available) and proposed scenarios. To provide more accurate summarization of streamflow results at gaged reporting locations, the simulated pre-settlement and proposed streamflow results were adjusted with observed values to better deter- 
mine the relative differences between simulated scenarios. This adjustment procedure is discussed further in the "Model Scenarios" section of this report. Potential errors in simulated flow values also are limited by presenting results in terms of relative differences. Relative differences in proposed results isolate differences as a result of the addition of impoundments, and the range of uncertainties in impoundment design are quantified using the $10^{\text {th }}$-, $50^{\text {th }}$ - and $90^{\text {th }}$-percentile of estimated input design information.

Despite errors and uncertainty in all numerical simulations as a result of simplifications, HSPF and the associated calibration and validation techniques represent the "state of the science" in determining basin-scale hydrologic processes - including the possible effects of impoundments and land-cover changes on streamflows. Poor calibration results for low flows limit the direct use of non-adjusted results; however, the general trends (did flows increase or decrease as a result of this simulated change?), and relative quantitative differences between the pre-settlement or proposed simulations and current conditions are reasonable and useful products from the model.

\section{Model Scenarios}

Pre-settlement, current, and proposed impoundment scenarios were developed for the Marais des Cygnes, Little Osage, and Marmaton River model areas (fig. 10). The same 1995-2004 meteorologic inputs were used for all scenarios, but land cover, impoundments, and point-source withdrawals and discharges were varied (table 15). The pre-settlement scenario represented historical land cover (fig. 4), and did not include impoundments or point-source withdrawals and discharges. The hydrologic properties of native prairie soils have been determined to have an order of magnitude greater hydraulic conductivity compared with cultivated soils (Fuentes and others, 2004). The INFILT value for prairie/rangeland land cover from the pre-settlement scenario was, therefore, doubled (compared with agriculture, pasture, and rangeland INFILT values from the current and proposed scenarios) in an attempt to estimate the effects of the probable greater hydraulic conductivity under pre-settlement conditions. Current scenarios included 1992-1995 land cover, existing impoundments (2005), and 1995-2004 reported point-source withdrawals and discharges. A proposed scenario, (Prop-all), was developed for the Marais des Cygnes River that included all existing and proposed impoundments, 1992-1995 land cover, and current point-source withdrawals and discharges. Two proposed scenarios were developed for the Marmaton River Basin; one containing a select group of four soon-to-be-constructed impoundments in addition to all existing impoundments (Prop-sel), and another that included existing and all proposed impoundments (Prop-all). Both proposed Marmaton River Basin scenarios (Prop-sel, Prop-all) included 1992-1995 land cover and current point-source withdrawals and discharges. No proposed scenario was developed for the Little Osage River as no additional impoundments were proposed for this basin.

The Prop-sel simulation for the Marmaton and the Prop-all simulations for the Marais des Cygnes and Marmaton River Basins each included three different scenarios accounting for possible variability in impoundment design. As described previously in the "Stage-area and Stage-volume outflow relations" section of this report, three outflow ratings $\left(10^{\text {th }}-, 50^{\text {th }}\right.$, and $90^{\text {th }}$-percentile outflow characteristics) were constructed for each proposed impoundment with any missing design variables. In this way the variability in streamflow as a result of design uncertainty could be quantified along with the applicability of using proposed impoundment design as a means of controlling the cumulative effects of impoundments.

To obtain the most accurate simulated streamflow possible, at locations where observed streamflow data were available, each value in the hourly or daily simulated-scenario time series was multiplied by the corresponding ratio of hourly or daily observed streamflow to simulated current flows to adjust for possible biases associated with the simulations. The relative differences between the observed and simulated scenarios, as a result of modifications for proposed or pre-settlement conditions, were quantified and isolated, and these differences were applied to the simulated scenario (pre-settlement or proposed) flows. For example, the differences between pre-settlement streamflow and current simulation results were considered proportional to the differences between a new presettlement adjusted time series and the observed streamflows as follows:

$$
\frac{\text { Pre }+ \text { infilt }}{\text { Current }}=\frac{\text { Pre }+ \text { infilt }}{\text { adj }}
$$

or alternatively,

$$
\text { Pre }+ \text { infilt }_{a d j}=\frac{(\text { Pre }+ \text { infilt } \times \text { Observed })}{\text { Current }}
$$

where

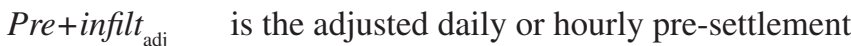
streamflow time series with an INFILT parameter value double that used in the Current scenario,

Pre+infilt is the simulated daily or hourly pre-settlement streamflow time series with an INFILT parameter double that used in the Current scenario,

Current is the simulated daily or hourly streamflow values for the 1995 land-cover and current (2005) impoundment conditions, and

Observed is the observed daily or hourly streamflow values at USGS streamflow-gaging stations.

At those locations where observed values were available, the adjusted simulation scenario values are presented, other- 


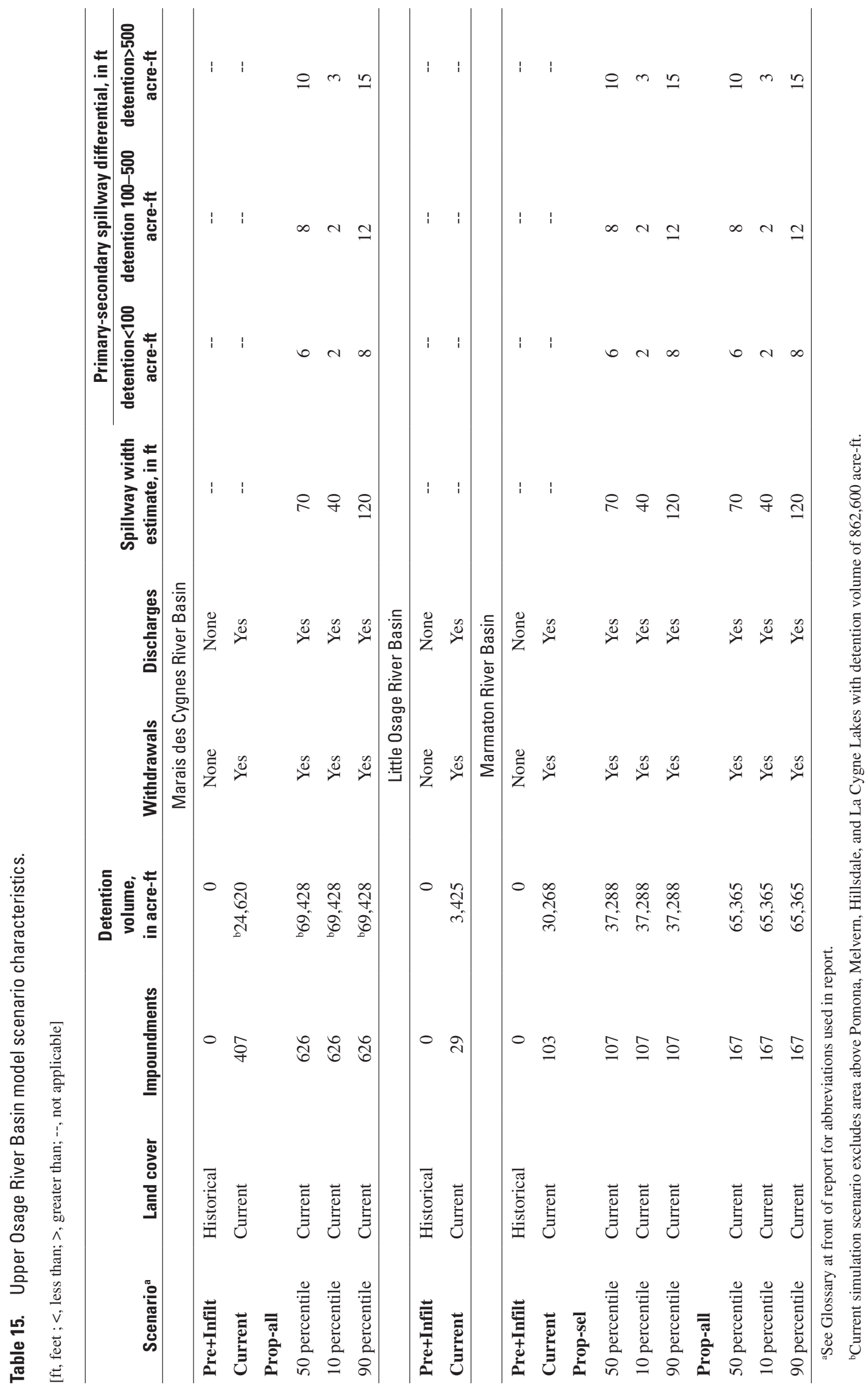


wise simulated values are presented. Values were adjusted for six of the nine reporting locations used in this report (table 16). Other simulated or adjusted streamflow-time series generated in this study included:

Prop-sel50 Simulated proposed streamflow time series using selected proposed impoundments and median values as estimates for any missing impoundment design criteria.

Prop-sel10 Simulated proposed streamflow time series using selected proposed impoundments and $10^{\text {th }}$-percentile values as estimates for any missing impoundment design criteria.

Prop-sel90 Simulated proposed streamflow time series using selected proposed impoundments and $90^{\text {th }}$-percentile values as estimates for any missing impoundment design criteria.

Prop-sel50 adj Adjusted proposed streamflow time series for selected proposed impoundments using median estimates for any missing impoundment design criteria.

Prop-sel10 adj Adjusted proposed streamflow time series for selected proposed impoundments using $10^{\text {th }}$-percentile estimates for any missing impoundment design criteria.

Prop-sel90 adj Adjusted proposed streamflow time series for selected proposed impoundments using $90^{\text {th }}$-percentile estimates for any missing impoundment design criteria.

Prop-all50 Simulated proposed streamflow time series using all proposed impoundments and median estimates for any missing impoundment design criteria.

Prop-all10 Simulated proposed streamflow time series using all proposed impoundments and $10^{\text {th }}$-percentile estimates for any missing impoundment design criteria.

Prop-all90 Simulated proposed streamflow time series using all proposed impoundments and $90^{\text {th }}$-percentile estimates for any missing impoundment design criteria.

Prop-all50 adj Adjusted proposed streamflow time series using all proposed impoundments using median estimates for any missing impoundment design criteria.

Prop-all10 $_{\text {adj }} \quad$ Adjusted proposed streamflow time series using all proposed impoundments using $10^{\text {th }}$-percentile values as estimates for any missing impoundment design criteria.

Prop-all90 $_{\text {adj }} \quad$ Adjusted proposed streamflow time series using all proposed impoundments using $90^{\text {th }}$-percentile values as estimates for any missing impoundment design criteria.

Comparisons of the magnitude, frequency, duration, and timing of the various streamflow time series were conducted using the Indicators of Hydrologic Alteration analysis software (The Nature Conservancy, 2005).

\section{Computation of Fish Habitat Area under Simulated Streamflow Scenarios}

The streamflow time series resulting from the various hydrologic simulations were used in conjunction with existing developed streamflow-habitat area time series to compare and quantify the effects of altered streamflow on fish-habitat area availability. Streamflow-fish habitat area relations previously were developed for 26 species/life stage categories (Heimann and others, 2005) at three near-state-line locations on the Marais des Cygnes River (RCHRES 90, RCHRES 93, RCHRES 95; fig 12), and two near-state-line locations on the Marmaton River (RCHRES 6, RCHRES 11; fig. 13. Daily streamflow time series were used to develop selected daily fish-habitat area time series for 9 of the 26 categories (table 17) for this study. These nine categories were selected to represent a variety of seasonal conditions, and because of the associated level of vulnerability with these categories as a result of spawning or juvenile development concerns (Heimann and others, 2005).

\section{Effects of Impoundments and Land- Cover Changes on Streamflows}

Hydrologic simulations were developed for the upper Osage River Basin for the 1995 through 2004 water years using land cover, impoundment, and withdrawal/discharge information representing pre-settlement, current, and proposed conditions. Comparisons of streamflow conditions were conducted using a generalized water balance along with selected ecological flow characteristics (magnitude, frequency, duration, and timing) for the different simulation scenarios. The simulated streamflow time series also were used to compute fish habitat area at selected Marais des Cygnes and Marmaton River locations near the Kansas-Missouri state line for selected fish species/life stages to quantify the effects of simulated flow alterations on stream channel habitat. Comparisons are made between simulated proposed conditions and observed record when streamflow record is available, but if streamflow record is not available at a reporting location the comparisons are made to simulated current conditions.

\section{Water Balance}

Runoff volume and actual evapotranspiration statistics for the Marmaton River Basin (1995 through 2004 water years), provide an indication of the effects of land-cover and regulation changes on the water balance in the study basins (table 18). The addition of impoundments under proposed conditions had no substantial effect on the 10-year total runoff as current, no-impoundment; current, with-impoundment; and proposed impoundment scenarios all had 7,770 thousand acre-feet of total runoff during the 10 -year simulation period (table 18). 


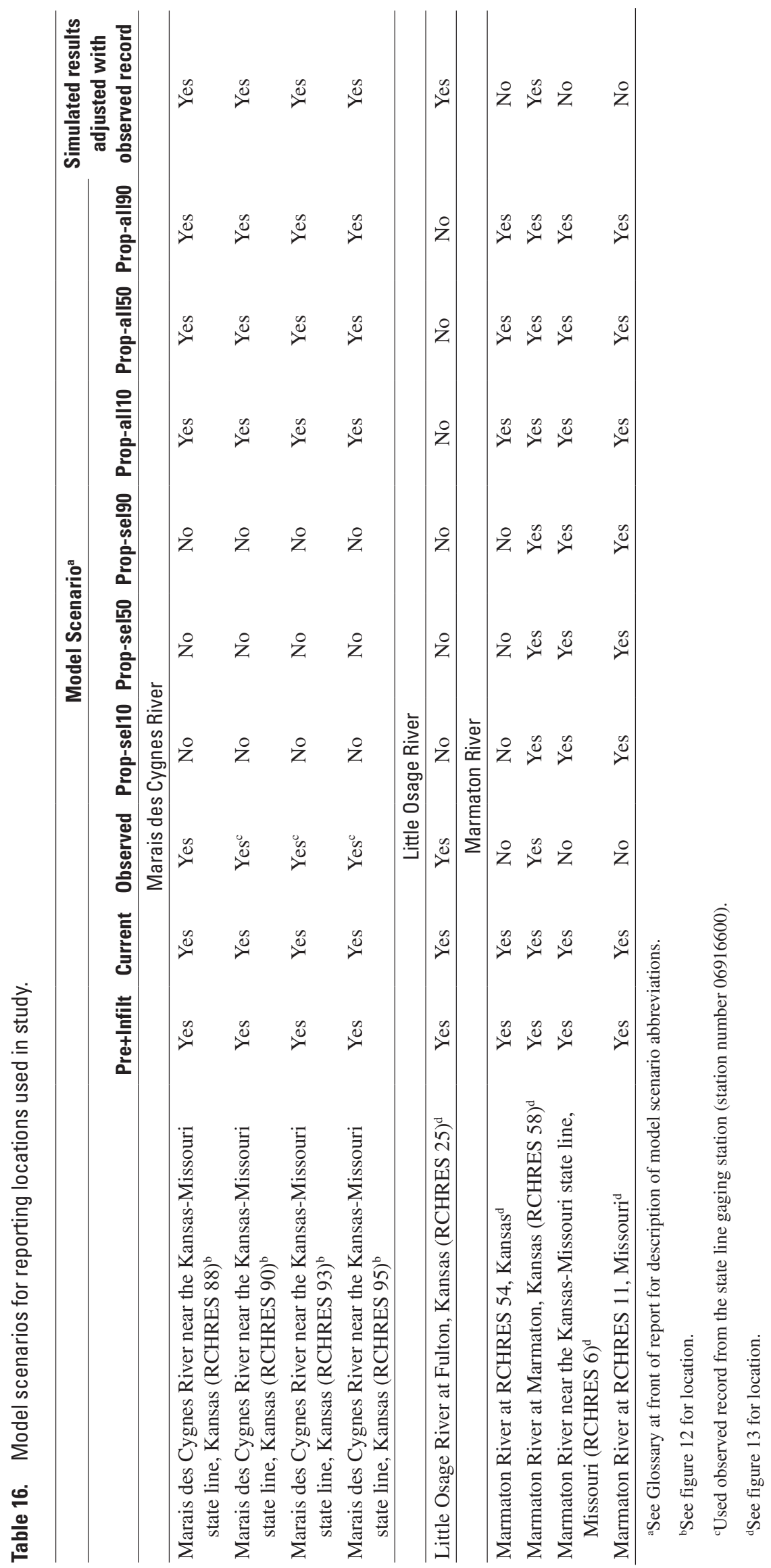


The change from historical land cover (pre-settlement using current INFILT) to current land cover (Current, no-impoundments scenario with water use) resulted in a decline of 120 thousand acre-feet of total runoff (table 18) indicating that the combined land-cover changes (100 thousand acre-feet) and net water use losses (20 thousand acre-feet; table 18) may have a greater effect on total runoff than impoundments. The sensitivity of the model to the INFILT parameter was evidenced by the 190 thousand acre-feet decline in total runoff between the Pre-settlement (current INFILT) and Pre+infilt scenarios (table 18); the largest runoff difference between any two scenarios.

Surface runoff was 70 to 90 thousand acre-feet less under the pre-settlement (current INFILT) scenario compared with the current and proposed scenarios, indicating differences resulting from land cover and water use (table 18). The doubling of the INFILT model parameter (index to mean soil infiltration rate) between the Pre-settlement (current INFILT) and Pre+Infilt scenarios resulted in a 640 thousand acre feet difference in surface runoff. Runoff volume for the 50 percent lowest streamflows was the least for the Current, noimpoundment and Pre-settlement (current INFILT) scenarios and greatest for the Prop-all50 and Pre+infilt scenarios. Conversely, streamflow for the 10 percent highest flows was greatest for the Pre-settlement (current INFILT) and Current, no-impoundment scenarios and least for the Prop-all50 and Pre+infilt scenarios (table 18). These differences can be attributed to the effects of impoundments and changes in infiltration on the streamflow hydrograph, rather than to other changes in land cover and water use.

Impoundments decreased hydrograph peaks and extended the recession limb of hydrographs in the simulations (fig. 23), whereas increased infiltration had similar effects. Potential impoundment retention volume (water stored below the primary spillway outflow level), and particularly the impoundment detention volume (water temporarily stored between the primary and emergency spillway outflow levels), increased substantially under proposed scenarios (tables 15, 18; fig. 24). The temporal variability in outflow characteristics for a single impoundment demonstrated the variability associated with proposed impoundment design scenarios and the potential effects on streamflow magnitude (fig. 25). Impoundment outflows for a single, isolated, impoundment under "normal", "wet", and "dry" precipitation years indicate that both low flows and high flows may be affected by design characteristics. The $10^{\text {th }}$-percentile design scenario, representative of smaller outflow structures and longer detention time, resulted in the longest hydrograph recessions and lowest peak flows (fig. 25). The $90^{\text {th }}$-percentile design scenario, representative of larger possible outflow structures and shorter detention time, resulted in the fastest hydrograph recessions and highest peak flows of the three proposed impoundment design scenarios (fig. 25).

Evapotranspiration losses from the land and open water surfaces varied little between current and proposed scenarios, but could account for the differences in total runoff between pre-settlement (current INFILT) and the current and proposed 

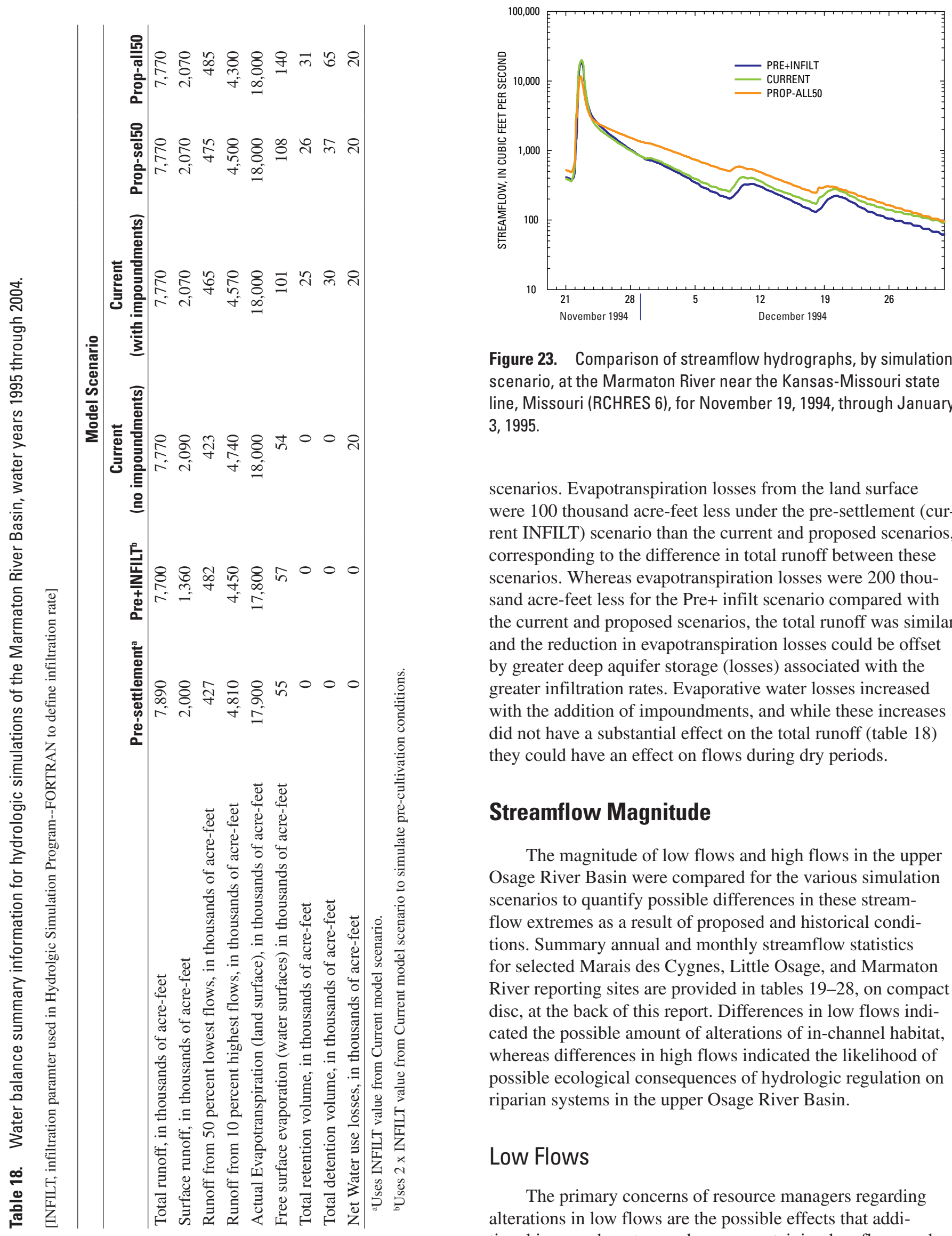

Figure 23. Comparison of streamflow hydrographs, by simulation scenario, at the Marmaton River near the Kansas-Missouri state line, Missouri (RCHRES 6), for November 19, 1994, through January 3, 1995.

scenarios. Evapotranspiration losses from the land surface were 100 thousand acre-feet less under the pre-settlement (current INFILT) scenario than the current and proposed scenarios, corresponding to the difference in total runoff between these scenarios. Whereas evapotranspiration losses were 200 thousand acre-feet less for the Pre+ infilt scenario compared with the current and proposed scenarios, the total runoff was similar and the reduction in evapotranspiration losses could be offset by greater deep aquifer storage (losses) associated with the greater infiltration rates. Evaporative water losses increased with the addition of impoundments, and while these increases did not have a substantial effect on the total runoff (table 18) they could have an effect on flows during dry periods.

\section{Streamflow Magnitude}

The magnitude of low flows and high flows in the upper Osage River Basin were compared for the various simulation scenarios to quantify possible differences in these streamflow extremes as a result of proposed and historical conditions. Summary annual and monthly streamflow statistics for selected Marais des Cygnes, Little Osage, and Marmaton River reporting sites are provided in tables 19-28, on compact disc, at the back of this report. Differences in low flows indicated the possible amount of alterations of in-channel habitat, whereas differences in high flows indicated the likelihood of possible ecological consequences of hydrologic regulation on riparian systems in the upper Osage River Basin.

\section{Low Flows}

The primary concerns of resource managers regarding alterations in low flows are the possible effects that additional impoundments may have on sustaining low flows and 

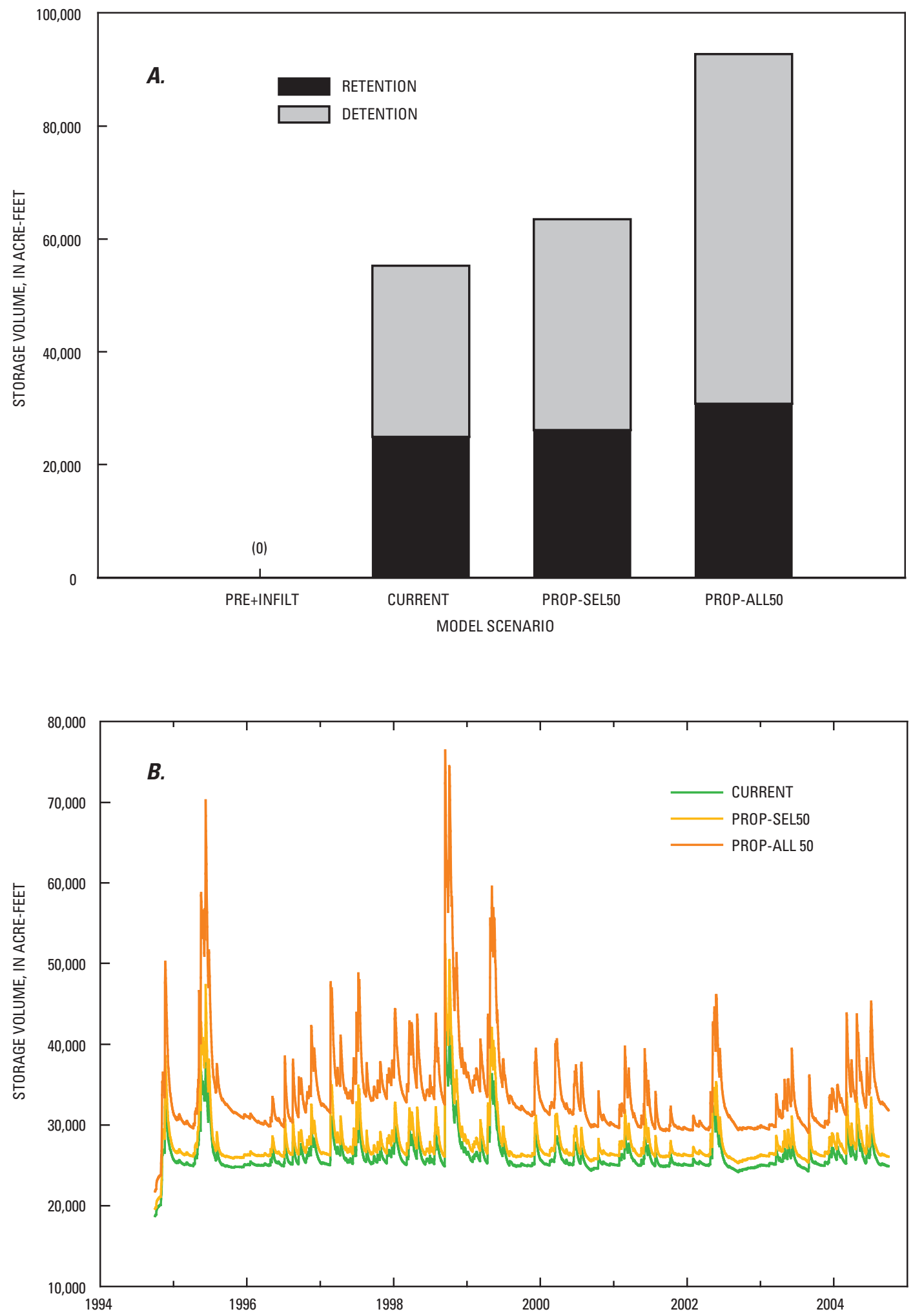

Figure 24. (A) Total potential impoundment retention and detention volume and $(B)$ temporal variability in simulated impoundment storage in the Mamaton River Basin by simulation scenario. 

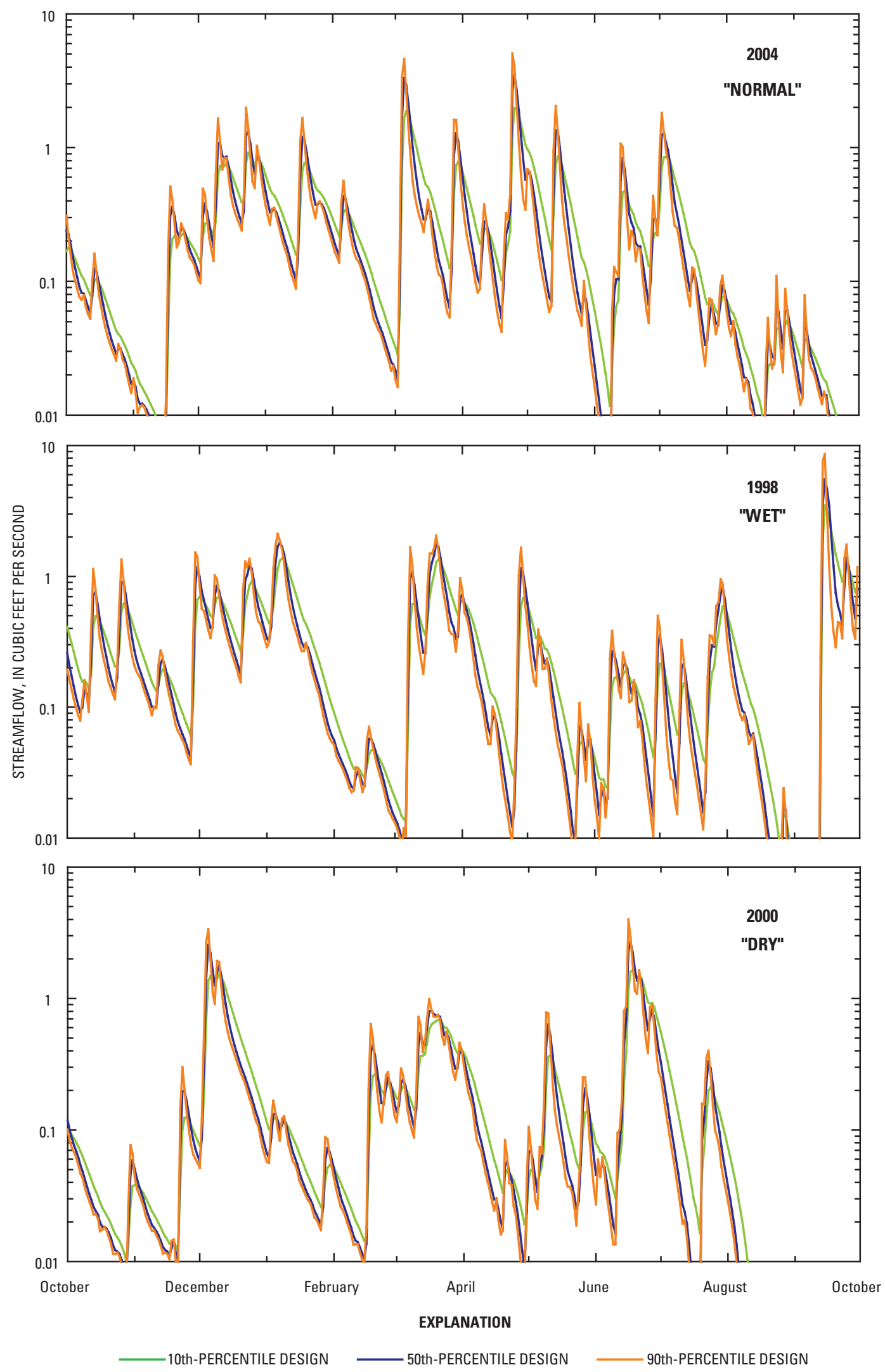

Figure 25. Comparison of outlfows from a single Marmaton River impoundment by outlfow design and range of selected annual climatic conditions. 
corresponding in-stream habitat in the upper Osage River Basin. Low flow reductions would exacerbate minimum flow conditions that already result in periods of limiting habitat or "bottlenecks". Differences in monthly minimum flow characteristics were compared by site, scenario, duration (1-, 3-, 7-, 30-days), and time (monthly, annual).

Differences in monthly proposed minimum 1-, 3-. 7-, and 30-day low flows from observed flows at the Marais des Cygnes River near the Kansas-Missouri state line, Kansas (RCHRES 88; fig. 12), for the 10-year simulation period, indicated that decreases in minimum flows were common [appendix 4 (figures 4-1 to 4-120), on compact disc, at the back of this report; tables 19, 24]. The Prop-all10 adj scenario (greatest detention characteristics) resulted in the least decreases in low flows relative to Observed flows; the Prop-all90 adj scenario (least detention characteristics) resulted in the greatest occurrence of low-flow declines (table 24). The maximum duration of declines in low flows was 4 months for the Prop-all50 and 5 months for the Prop-all90 adj with the longest period of extended declines occurring in the summer, 2001 and 2002. October had the greatest magnitude of declines in Prop-all50 adj monthly minimum 1-, 3-, 7-, and 30-day low flows compared with Observed flows at the Marais des Cygnes near the Kansas-Missouri state line, Kansas, but declines were present in April through November throughout the 10-year simulation period (fig. 26). The greatest declines under Prop-all50 adj conditions were for the lowest 10 percentile of Observed flows (fig. 27) and during the driest years (2000, 2001 water years; fig. 28). One obvious biologically important change in low flows that could occur would be an increase in zero flow days, but no proposed scenario resulted in a greater number of zero flow days at this site (table 24).

The most apparent difference in minimum flows at the Marais des Cygnes River near the Kansas-Missouri state line, Kansas, was between Observed and Pre+infilt ${ }_{\text {adj }}$ scenario results (appendix 4; tables 19, 24) indicating that the magnitude of changes that have occurred between pre-settlement and current conditions in this basin may be greater than what would be expected under proposed conditions. The 1-, 3-, 7-, and 30-day minimum flows were substantially greater for Observed flows than Pre+infilt ${ }_{\text {adj }}$ (tables 19, 24) as a result of controlled releases from large impoundments in this basin. Monthly minimum 1-, 3-, and 7-day Pre-infilt adj flows were as much as $6,600 \mathrm{ft}^{3} / \mathrm{s}$ less than the corresponding observed minimum flows (table 24). Observed flows also were less than Pre+infilt $t_{\text {adj }}$ scenario flows for several months with 30-day Pre+infilt ${ }_{\text {adj }}$ flows up to maximum of $2,800 \mathrm{ft}^{3} / \mathrm{s}$ greater than Observed, but differences generally were less than $300 \mathrm{ft}^{3} / \mathrm{s}$.

There were no additional impoundments proposed for the Little Osage River Basin and, therefore, proposed scenarios were not conducted for this basin. In contrast to differences detected in observed and pre-settlement low flows in the
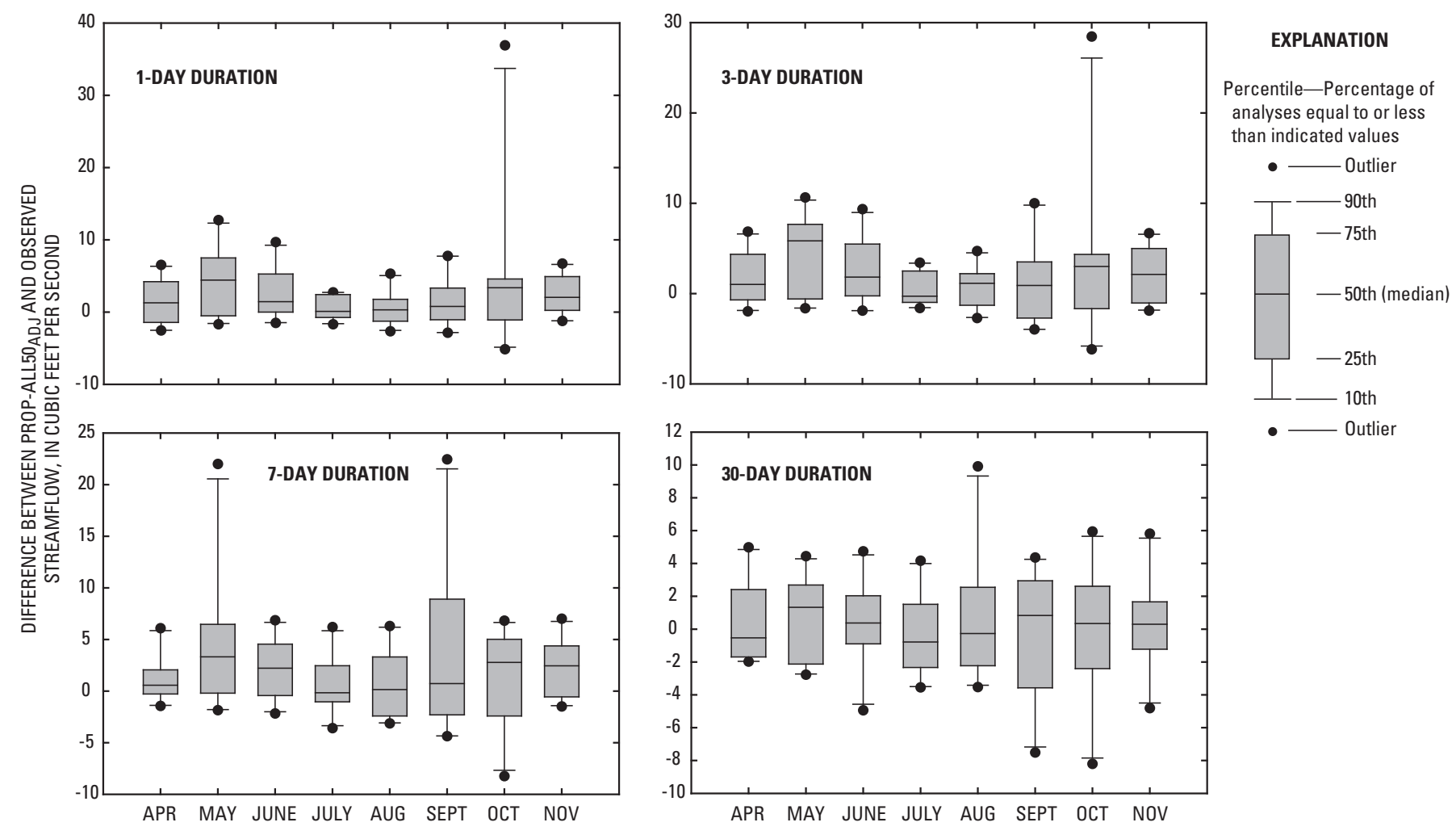

Figure 26. Distribution of differences between monthly minimum 1-, 3-, 7-, and 30-day Prop-all50 adj and Observed streamflows, by selected months, for the Marais des Cygnes River near the Kansas-Missouri state line, Kansas (RCHRES 88), water years 1995 through 2004. 


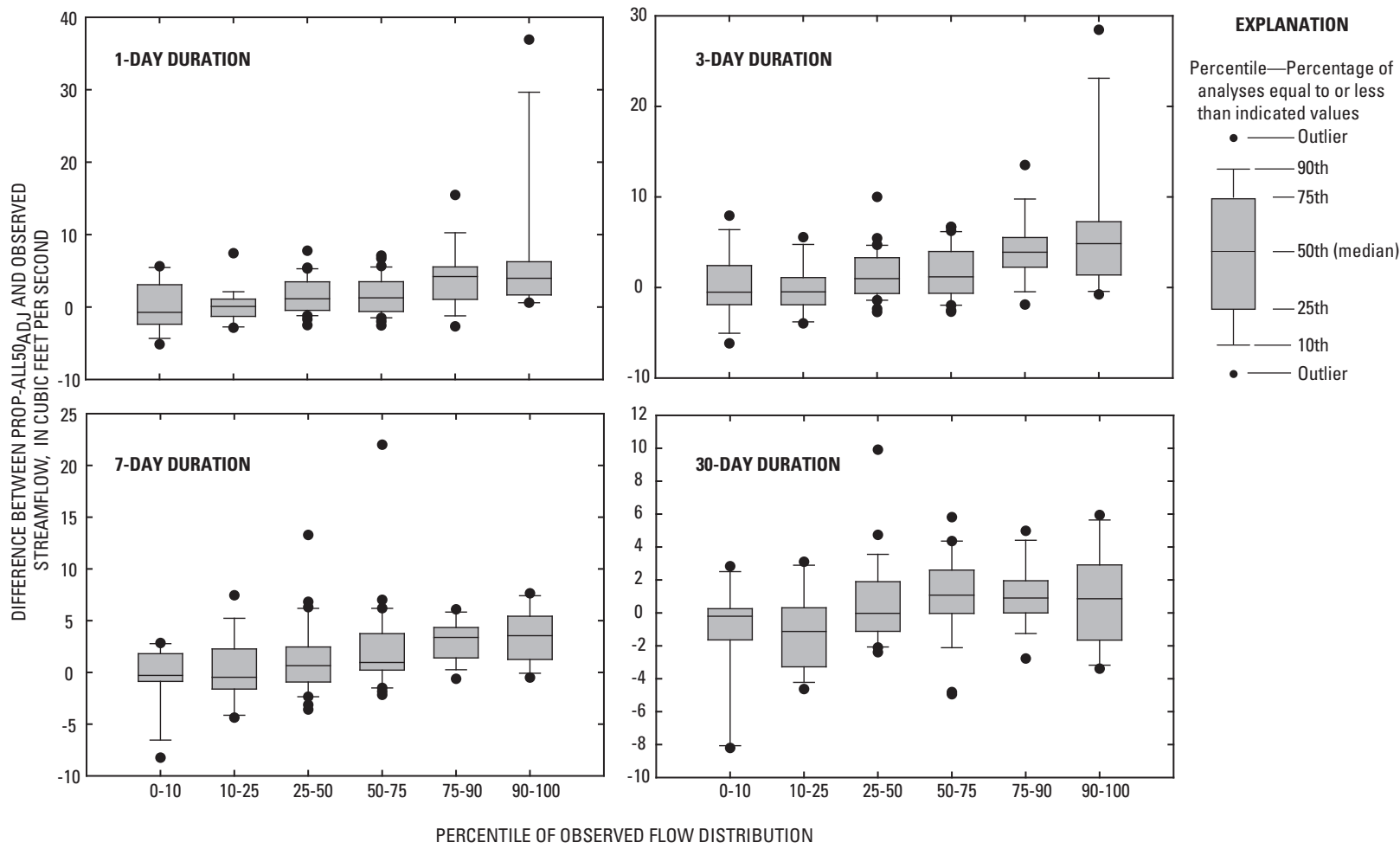

Figure 27. Distribution of differences between monthly 1-, 3-, 7-, and 30-day minimum Prop-all50 adj and 0bserved streamflows, by distribution of Observed flows, for the Marais des Cygnes River near the Kansas-Missouri state line, Kansas (RCHRES 88), water years 1995 through 2004.

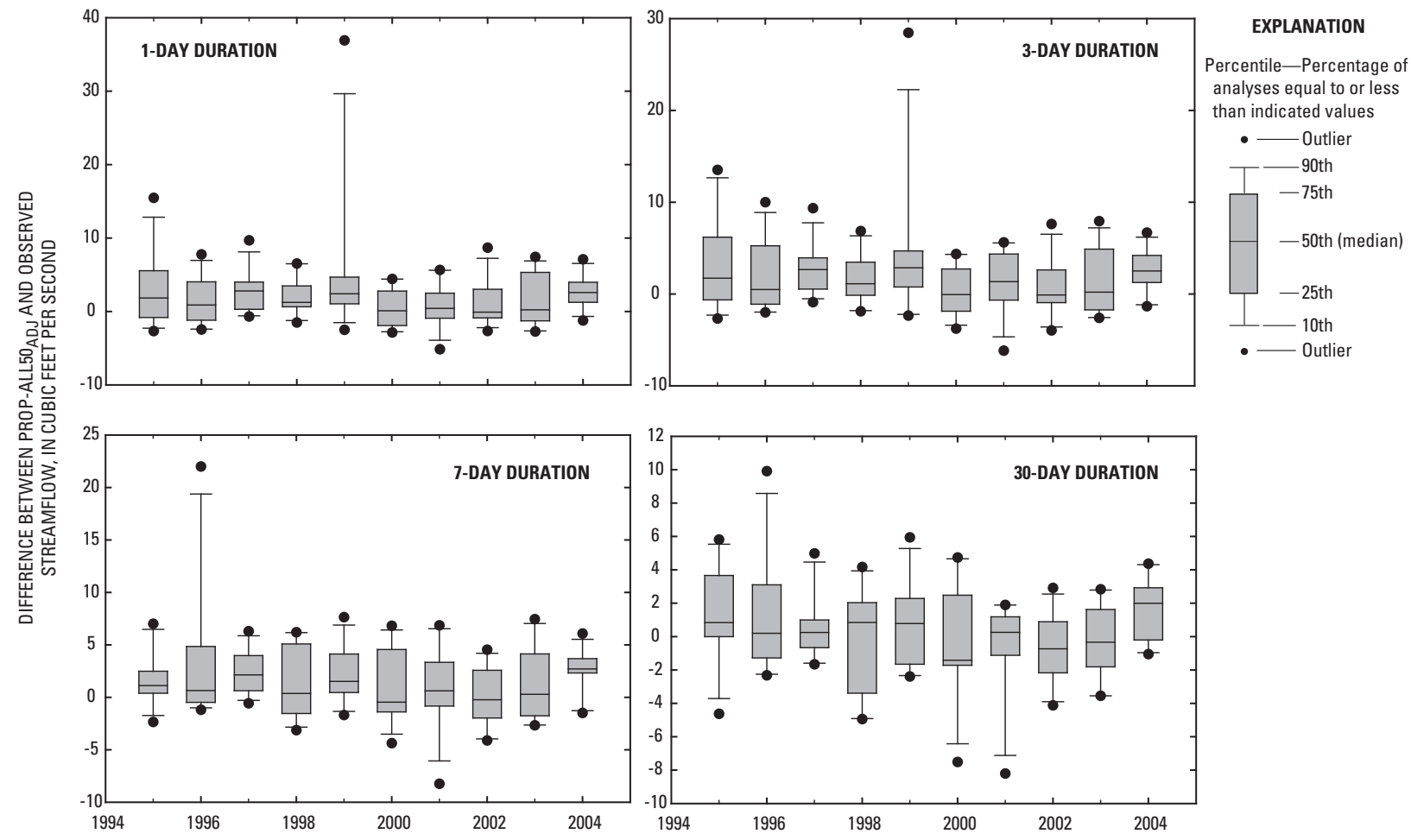

Figure 28. Distribution of differences between monthly minimum 1-, 3-, 7-, and 30-day Prop-all50 ${ }_{\text {adj }}$ and Observed streamflows, by year, for the Marais des Cygnes River near the Kansas-Missouri state line, Kansas (RCHRES 88), water years 1995 through 2004. 
Marais des Cygnes River Basin, the Pre+infilt adj low flows generally were greater than Observed flows at the Little Osage River near Fulton, Kansas (RCHRES 25; fig. 13; table 20, 25). The increased minimum low flows under simulated historical conditions compared with Observed flows resulted from greater INFILT parameter values representing greater infiltration and hydraulic conductivity characteristics of historical uncultivated prairie soils. The reduction in the extent of native prairies was the primary difference between current and historical conditions in this basin as affects from impoundments were minimal. Pre+infilt ${ }_{\text {adj }}$ low flows seemed to be particularly better sustained than Observed flows during dry years (water years 2000-2003), and with increasing flow duration (from 1-day to 30-day periods; table 20,25). The magnitude of the maximum differences between Pre+infilt ${ }_{\text {adj }}$ and Observed flows generally was less than $100 \mathrm{ft}^{3} / \mathrm{s}$ (table 25).

Differences in low-flow characteristics for simulated and Observed (or Current simulated scenarios at ungaged sites) are presented for multiple locations in the Marmaton River Basin to present the spatial variability in potential effects from impoundments and land-cover changes. In a small headwater basin in the upper Marmaton River Basin (RCHRES 54; fig. 13) simulated declines in minimum flows were small (generally less than $6 \mathrm{ft}^{3} / \mathrm{s}$ and less than $1 \mathrm{ft}^{3} / \mathrm{s}$ for 1 - and 3-day scenarios), but resulted in 10 to 18 additional zero flow days for the Prop-all50 and Prop-all90 scenarios relative to Current conditions (table 26). Declines primarily occurred during the summer months when minimum flows already were near zero flow and the largest duration of consecutive declines from existing conditions was 6 months for the Prop-all90 30-day duration for the summer and fall of 2002. Simulated Pre+infilt minimum flows generally were greater than Current simulated flow conditions for all flow duration periods. Maximum monthly differences generally were less than $10 \mathrm{ft}^{3} / \mathrm{s}$ (table 26).

Differences between simulated and observed minimum monthly flows were similar at a downstream Marmaton River near Marmaton, Kansas (RCHRES 58; fig. 13), site to those at the headwater site. Reductions in minimum monthly flows as a result of additional impoundments generally were less than $5 \mathrm{ft}^{3} / \mathrm{s}$ (tables 22, 27) but resulted in additional zero flow days for all flow duration periods (table 27). The maximum duration of consecutive monthly declines from Observed conditions was 5 months for the Prop-all90 adj simulation in the summer of 1995 (table 27). The number of additional zero flow days at the Marmaton River near Marmaton, Kansas, location were fewer ( 6 days; table 27 ) than at the headwater site (18 days; table 26). Simulated pre-settlement (Pre+infilt $t_{\text {adj }}$ ) monthly minimum flows at the Marmaton River near Marmaton, Kansas, generally were greater than Observed flows (tables 22, 27). Maximum monthly reductions in minimum flows between Pre+infilt adj and Observed flows, as a result of increased INFILT parameter representing land-cover changes, were 36 to $71 \mathrm{ft}^{3} / \mathrm{s}$ (table 27).

Similar to the headwater and Marmaton, Kansas, locations, the reductions in flows at the Marmaton River near the
Kansas-Missouri state line, Missouri (RCHRES 6; fig. 13), as a result of proposed impoundments, were most frequent for the Prop-all90 (least detention) scenario and generally occurred in the summer months [table 28; appendix 5 (figures 5-1 through 5-120), on compact disc, at the back of this report]. The maximum duration of declines in proposed scenario low flows relative to current flows was 6 months for the Prop-all90 scenario in the summers of 2000 and 2002 for multiple flow duration periods. July, August, and October had the largest declines in Prop-all50 low flows relative to Current scenario low flows during the 10-year simulation period (fig. 29). The greatest declines between Prop-all50 and Current flows generally occurred in the lower 50 percentile of Current scenario flows (fig. 30) and during the drier years of 2001-2003 (fig. 31). Proposed conditions resulted in declines in the $0-10$ percentile flow values for the 1-, 3-, and 7-day duration periods. Simulated reductions for proposed scenarios did not result in an increase in zero flow days at this location. Pre+iniflt minimum flows were, again, generally greater than Current scenario flows for all flow duration periods (appendix 5; table 28) with maximum declines in monthly low flows of 150 to $165 \mathrm{ft}^{3} / \mathrm{s}$ between pre-settlement and current scenarios (table 28).

\section{High Flows}

Proposed scenario monthly high flows were reduced as a result of the addition of impoundments in all basins and at all reporting locations (fig. 32; tables 19-23). Observed 1-day, monthly maximum streamflows at the Marais des Cygnes near the Kansas-Missouri state line, Kansas, were, on average, 5 to $17 \mathrm{ft}^{3} / \mathrm{s}$ greater than proposed maximum monthly flows (fig. 32; table 19). Given the existing amount of controlled regulation in the basin, the proposed scenarios represent a small potential change and little variability resulting from impoundment design. Pre-settlement monthly maximum flows were, on average, 540 to $776 \mathrm{ft}^{3} / \mathrm{s}$ greater than Observed 1-day monthly maximum flows, indicating that similar to low flows, the characteristics of high flows in this basin also have undergone greater changes between pre-settlement to current conditions than would be expected from current to proposed conditions. These changes between pre-settlement and current conditions in this basin were, again, the result of several large impoundments with managed detention and outflow characteristics. Observed 1-day monthly maximum flows at the Little Osage River near Fulton, Kansas, were similar to pre-settlement monthly maximums as Observed flows only were $0.8 \mathrm{ft}^{3} / \mathrm{s}$ greater, on average, than Pre+infilt ${ }_{\text {adj }}$ monthly maximum flows (fig. 32; table 20).

The Observed or Current scenario 1-day monthly maximum flows were, on average, greater than pre-settlement or proposed flow conditions in the Marmaton River Basin. The possible increased infiltration under historical native prairies compared with current cultivated land and the addition of impoundments under proposed conditions resulted in reduced streamflow peaks. The 1-day monthly maximum Current scenario flows were, on average, 38 to $63 \mathrm{ft}^{3} / \mathrm{s}$ greater 

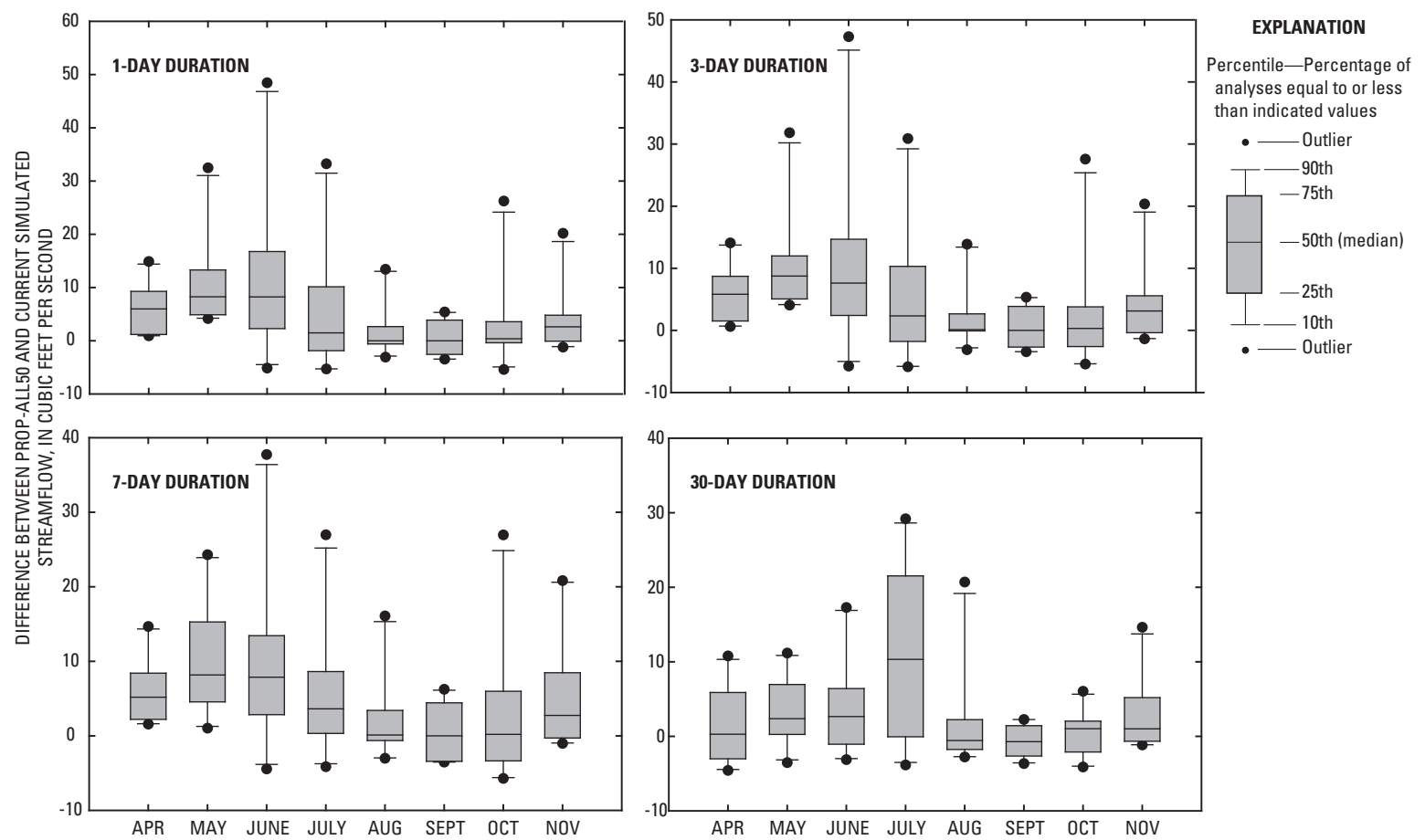

Figure 29. Distribution of differences between monthly minimum 1-, 3-, 7-, and 30 -day Prop-all50 and Current simulated streamflows, by months, for the Marmaton River near the Kansas-Missouri state line, Missouri (RCHRES 6), water years 1995 through 2004.

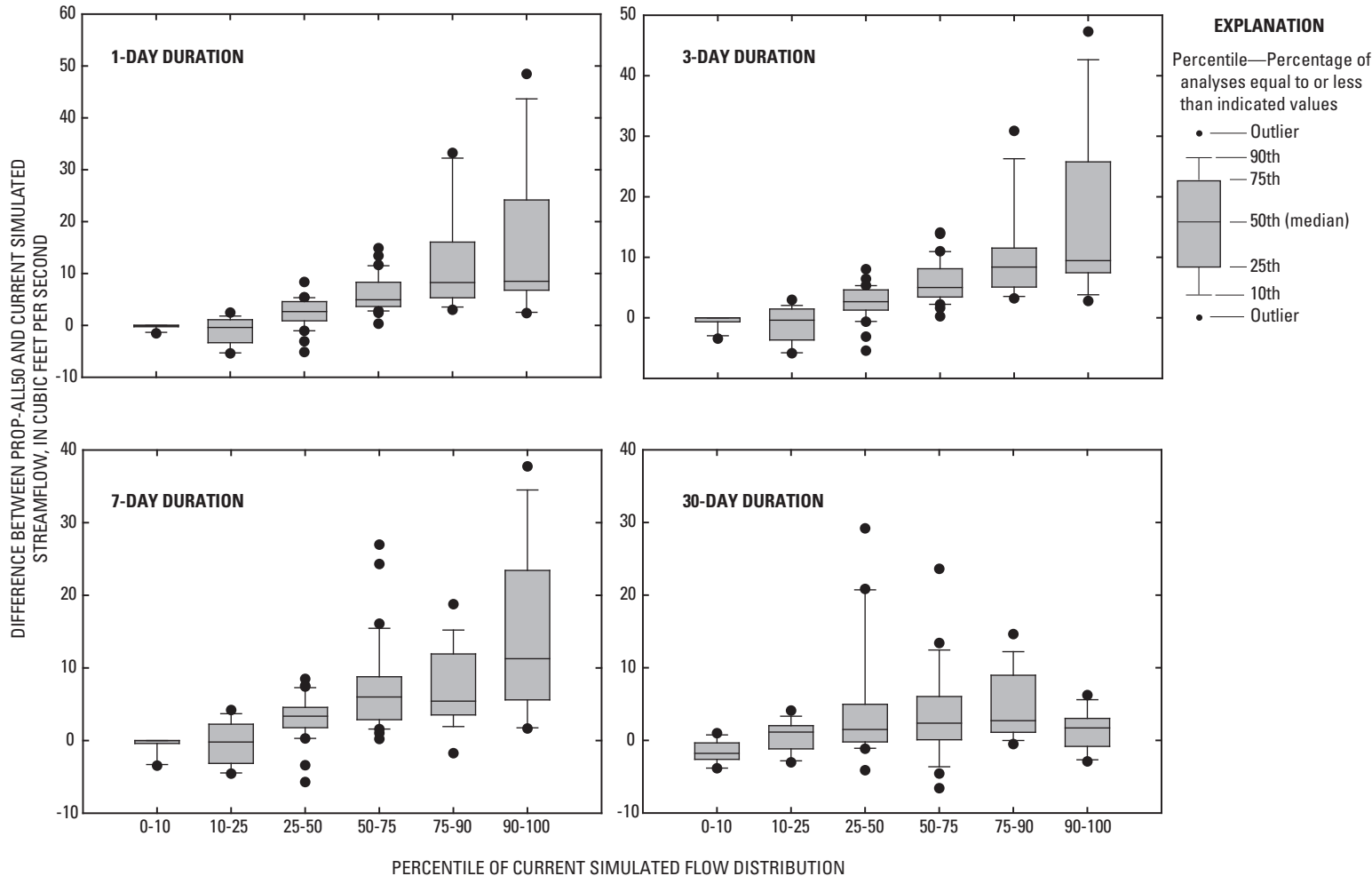

Figure 30. Distribution of differences between monthly minimum 1-, 3-, 7-, and 30 -day Prop-all50 and Current simulated streamflows, by distribution of Current simulated flows, for the Marmaton River near the Kansas-Missouri state line, Missouri (RCHRES 6), water years 1995 through 2004. 


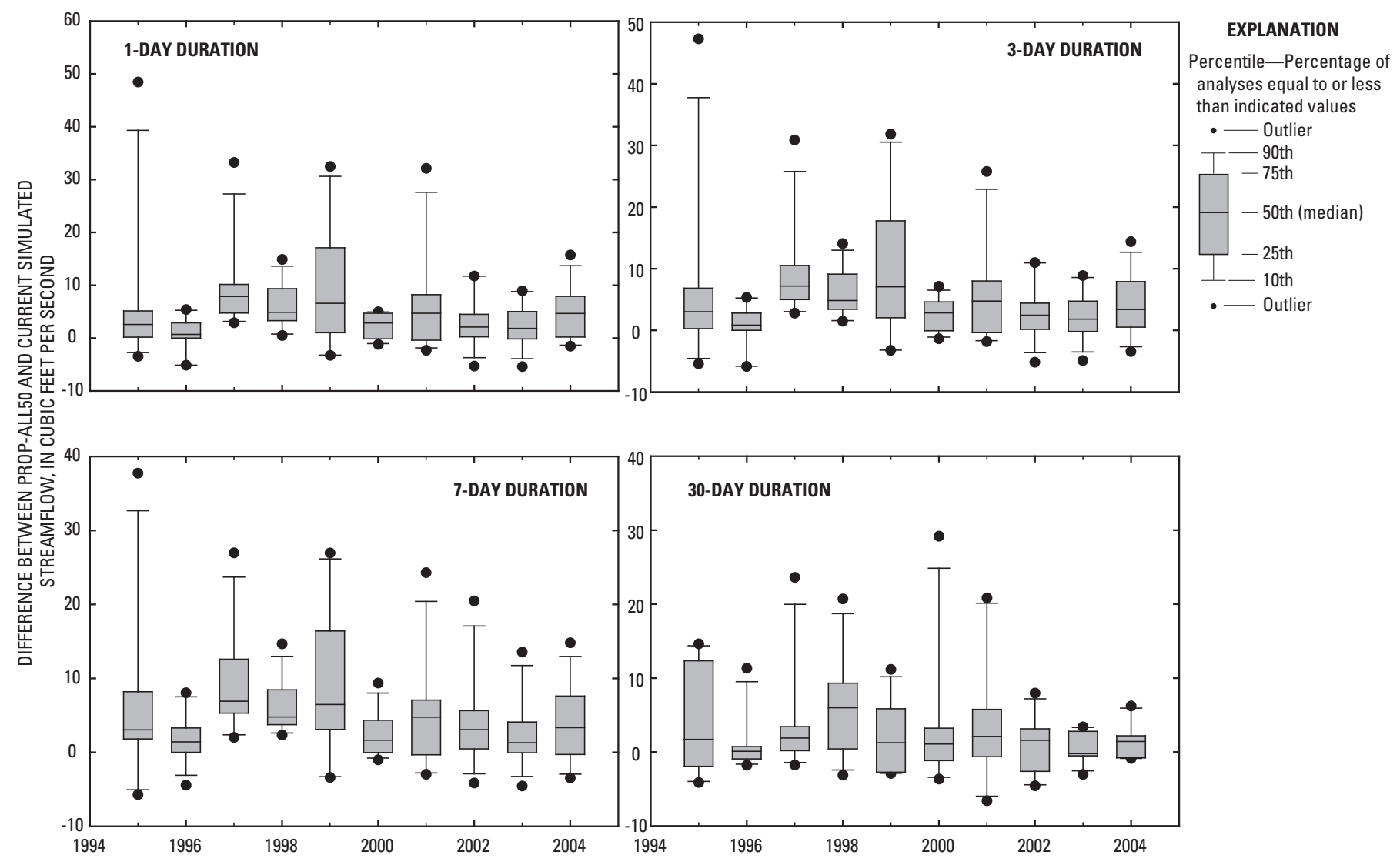

Figure 31. Distribution of differences between monthly minimum 1-, 3-, 7-, and 30 -day Prop-all50 and Current simulated streamflows, by year, for the Marmaton River near the Kansas-Missouri state line, Missouri (RCHRES 6), water years 1995 through 2004.

than proposed scenario maximum flows at the Marmaton River headwater location (RCHRES 54; fig. 32; table 21). The maximum median difference $\left(63 \mathrm{ft}^{3} / \mathrm{s}\right)$ was between the Current and Prop-all10 design scenario (greatest detention) and the least difference $\left(38 \mathrm{ft}^{3} / \mathrm{s}\right)$ was between the Current and Prop-all90 design scenario (least detention). Current scenario maximum monthly flows were about $24 \mathrm{ft}^{3} / \mathrm{s}$ greater, on average, than Pre+infilt scenario flows, again as a result of greater INFILT parameter values representing native prairie soils.

At the Marmaton River near Marmaton, Kansas, the

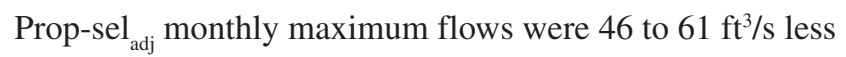
than Observed flows, on average (fig. 32; table 22), whereas the Prop-all ${ }_{\text {adj }}$ monthly maximum flows were 100 to $200 \mathrm{ft}^{3} / \mathrm{s}$ less than Observed flows, on average, depending on outflow design characteristics. Despite adding only four additional impoundments under the Prop-sel scenarios, there was a sizeable reduction in 1-day maximum flows. Additional impoundments under the Prop-all scenarios resulted in greater reductions in monthly maximum flows compared with Observed flows. In both proposed sets of scenarios, the $10^{\text {th }}$ - or $50^{\text {th }}$ - percentile scenario resulted in the greatest reduction and the $90^{\text {th }}$ percentile scenario the least. Pre+infilt ${ }_{\text {adj }}$ monthly maximum flows were, on average, $51 \mathrm{ft}^{3} / \mathrm{s}$ greater than Observed flows (fig. 32; table 22).
Current monthly maximum flows in the Marmaton River near the Kansas-Missouri state line, Missouri, were 46 to 64 $\mathrm{ft}^{3} / \mathrm{s}$ greater, on average, than Prop-sel $\mathrm{adj}_{\mathrm{d}}$ flows, and 173 to 300 $\mathrm{ft}^{3} / \mathrm{s}$ greater than Prop-all ${ }_{\text {adj }}$ monthly maximum flows, depending on impoundment outflow design (fig. 32; table 23). While the Prop-sel scenario differences were similar to those at the upstream Marmaton, Kansas location, the Prop-all scenario differences were greater, reflecting the additional regulation from proposed impoundments in the interim area between these locations. The Prop-all10 (greatest detention) design scenario again resulted in the greatest average declines in maximum flows $\left(300 \mathrm{ft}^{3} / \mathrm{s}\right)$ from Current conditions. Current scenario1-day monthly maximum flows at this site were 109 $\mathrm{ft}^{3} / \mathrm{s}$ greater than Pre+infilt ${ }_{\text {adj }}$ flows, on average (fig. 32; table 23).

\section{Flood Frequency}

An ecological consequence of a reduction in streamflow magnitude is a reduction in flood frequency. Natural flooding supplies a primary source of water replenishment to riparian wetlands in the upper Osage River Basin (Heimann and Mettler-Cherry, 2004) providing the physical mechanism for channel and flood plain formation, a primary factor in vegeta- 


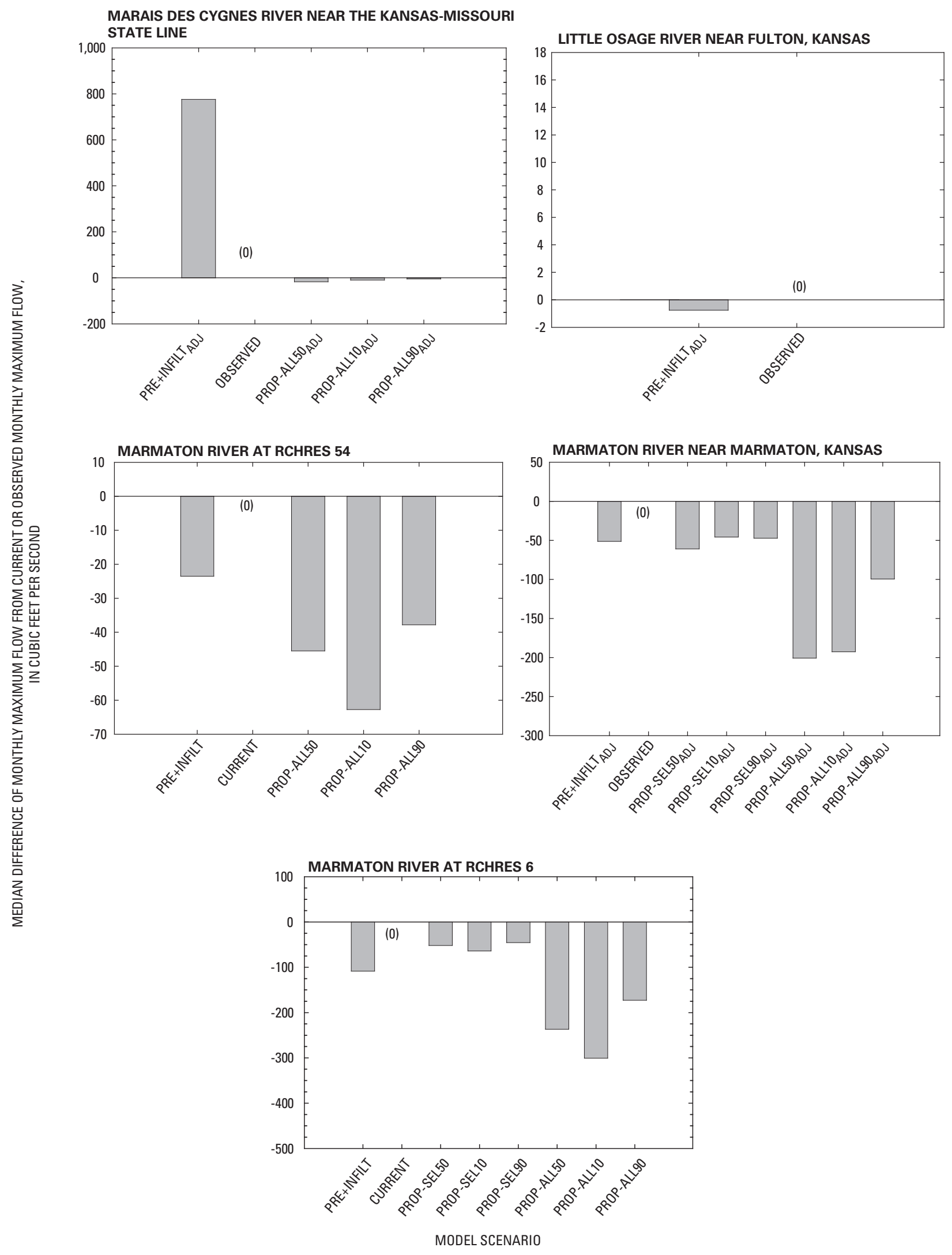

Figure 32. Median difference in 1-day monthly maximum flows from Current or Observed monthly maximum flow, by model basin and scenario, water years 1995 through 2004. 
tion composition, distribution, and maintenance as well as habitat for a variety of wildlife. Analyses of hourly simulated and adjusted time series indicated that flood frequency generally was reduced between Current and proposed scenarios in each model basin, although the degree of reduction varied with location in the basin.

The flood frequency for the Marais des Cygnes River near the Kansas-Missouri state line, Kansas, was substantially reduced between pre-settlement and observed conditions, but minimal change was simulated between Observed and proposed scenarios. Flood frequency under the pre-settlement scenario was 50 percent greater than the Observed scenario (fig. 33) for the 10-year simulation period. This reduction in flooding can be attributed to the substantial amount of current controlled regulation in the Marais des Cygnes River Basin. Flood frequencies remained unchanged between the Observed and proposed scenarios at this site as the additional regulation from the small, uncontrolled impoundments did not result in substantial reductions in flood peaks.

There were no differences between Pre+infilt ${ }_{\text {adj }}$ and Observed scenario flood frequency (fig. 33) at the Little Osage River near Fulton, Kansas. Despite land-cover changes, flooding characteristics remained similar in this basin and the effects from current impoundments was not substantial enough to result in changes in flood frequencies. There are no proposed impoundments in this basin, so flood characteristics should remain unchanged for the foreseeable future.

Flood frequency generally was greatest for the Current or Observed scenarios in the Marmaton River Basin and least for the proposed conditions and the effects of regulation on flood frequency decreases downstream from the Kansas-Missouri state line. The number of floods at the Marmaton River near Marmaton, Kansas, under the Prop-all adj scenario was 28 to 52 percent less than the Observed (fig. 33) scenario; the largest declines were associated with the Prop-all10 ${ }_{\text {adj }}$ scenario, and the least were from the Prop-all90 adj scenario. The flood frequency at the Marmaton River near Marmaton, Kansas,

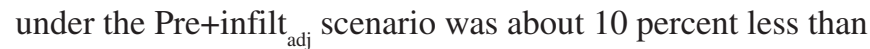
Observed scenario flood frequency conditions. The flood frequency of the Prop-all scenarios were 54 to 60 percent less (fig. 33) than Current scenario at the Marmaton River near the Kansas-Missouri state line, Missouri (RCHRES 6). The flood frequency of the Pre+infilt scenario was 15 percent less than Current simulated conditions. At the downstream Marmaton River RCHRES 11 site the total flood frequency reduction from Current simulated scenario to Prop-all conditions was less ( 21 to 26 percent) than the upstream RCHRES 6 site (fig. 33). The Pre+infilt scenario flood frequency was 9 percent less than the Current simulated scenario. The RCHRES 11 site is downstream from a primary Marmaton River tributary (Big Drywood Creek, fig. 1) with little local regulation and, therefore, the effects of proposed upstream regulation were reduced.

\section{Hydrograph Duration and Flooding Period}

The simulated effects of regulation on "large" (as reported in the "Indicators of Hydrologic Alteration" software results; tables 19-23) flood total hydrograph durations varied between model basins and with degree of regulation. Increased regulation increased the total hydrograph duration (duration from pre-event baseflow to post-peak baseflow) of floods. High flows were detained in the impoundments at levels above the primary spillway and released slowly until water levels again reached the level of the primary outflow structure, which extended the streamflow hydrograph duration. The average duration of large flood hydrographs was similar for Observed and proposed scenarios at the Marais des Cygnes River near Kansas-Missouri state line, Kansas (fig. 34). Pre-settlement scenario flood hydrograph durations were, on average, about 80 percent less than Observed. The average large flood hydrograph duration (fig. 34) at the Little Osage River near Fulton, Kansas, for the Pre+infilt ${ }_{\text {adj }}$ scenario, using assumed increased infiltration estimates under historical land cover, was about 120 percent greater than Observed scenario durations. At the Marmaton River RCHRES 54 and Marmaton River near Marmaton, Kansas, locations the average large flood hydrograph durations under proposed and pre-settlement scenarios were about 50 percent greater than Observed and Current scenarios (fig. 34). At the Marmaton River near the KansasMissouri state line, Missouri, the average proposed scenario flood hydrograph durations were 2 to 70 percent greater than Current simulated conditions depending on scenario, whereas flood hydrograph durations were similar under pre-settlement and Current simulated conditions.

Whereas the total hydrograph duration increased with regulation, the actual duration of streamflows above estimated flood levels decreased with proposed regulation in all model basins. The total duration of streamflows above flood levels (flooding period) at the Marais des Cygnes River near the Kansas-Missouri state line, Kansas, decreased only about 2 to 7 percent from Observed to Prop-all adj duration levels (fig. 35). The largest difference in flooding period at this Marais des Cygnes River site occurred between pre-settlement and Observed scenarios, in which Pre+infilt ${ }_{\text {adj }}$ average flooding period was more than 200 percent greater than Observed scenario flooding period. Pre-settlement flooding periods in the Little Osage River near Fulton, Kansas were similar (within 4 percent) to Observed scenario conditions (fig. 35). At the Marmaton River near Marmaton, Kansas, and near the Kansas-Missouri state line, Missouri, the average flooding period under Prop-all scenarios indicated a 50 to 60 percent reduction from Observed and Current scenario conditions (fig. $35)$. The Prop-all flooding periods were only 21 to 26 percent less than Current simulated conditions, on average, at the downstream Marmaton River near RCHRES 11 site (fig. 35). 


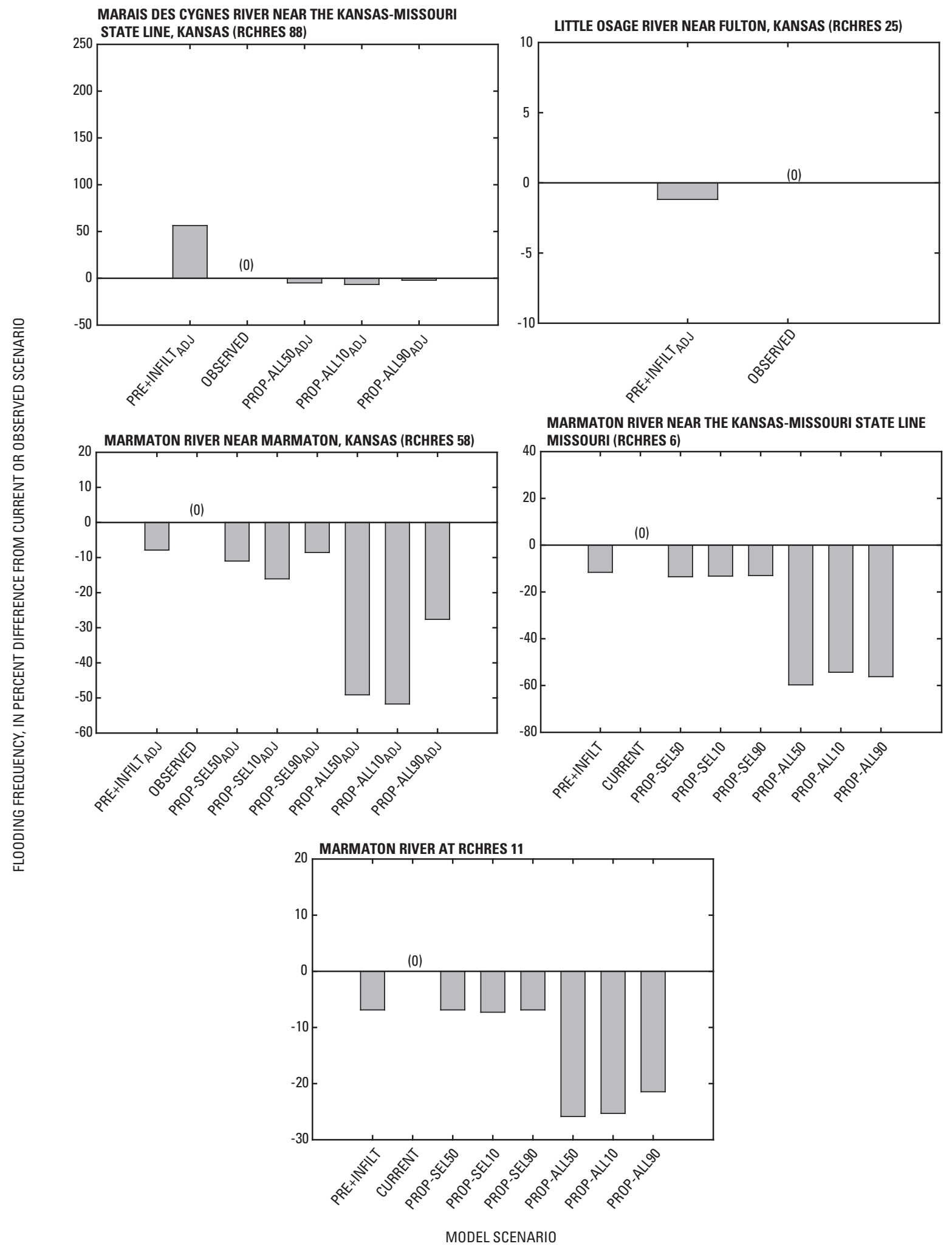

Figure 33. Differences in simulated flood frequency characteristics from Current simulated or Observed frequency, by model basin and scenario, water years 1995 through 2004. 

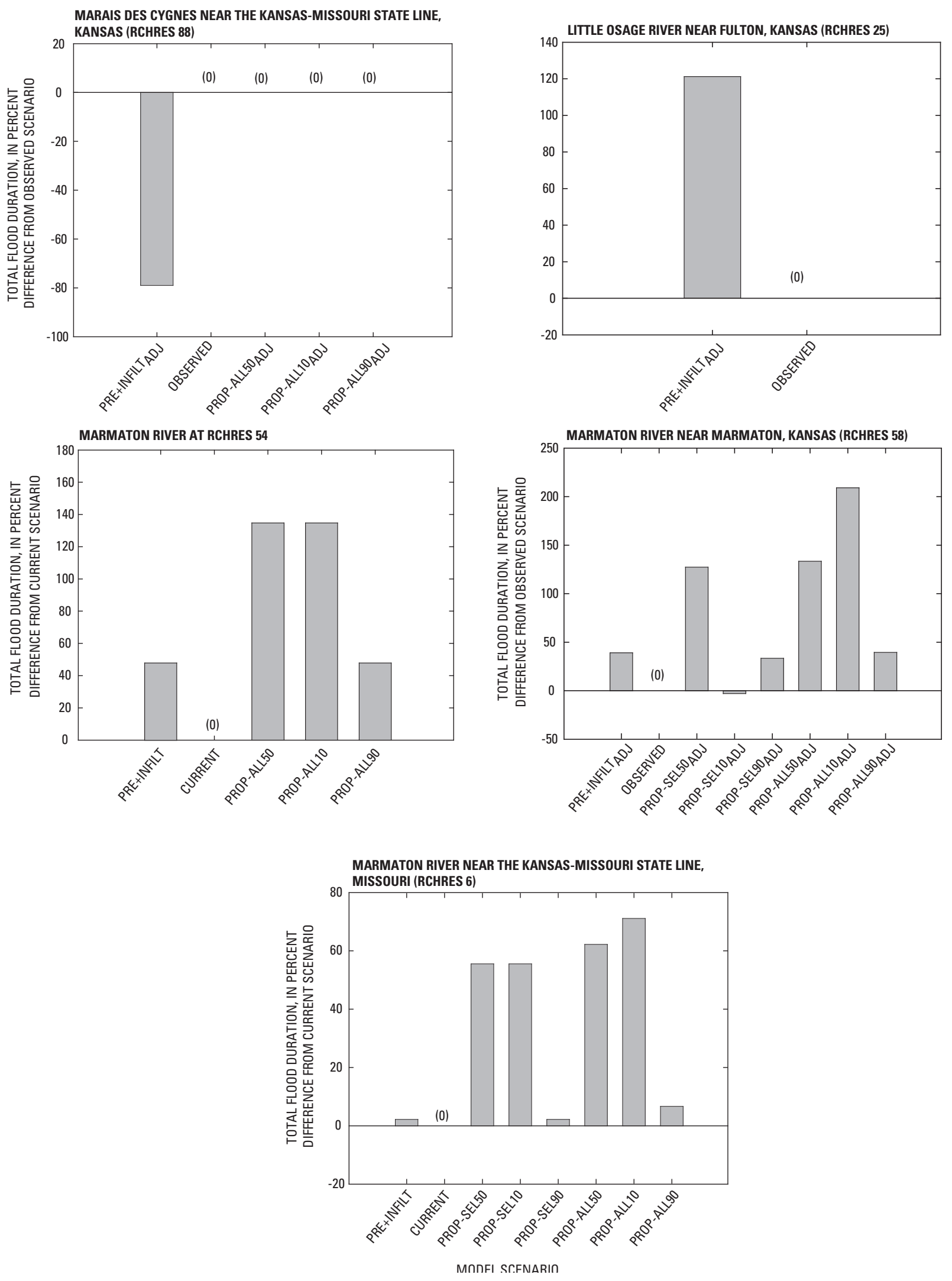

Figure 34. Differences in total large-flood hydrograph duration from Current simulated or Observed conditions, by model basin, reporting site, and simulation scenario, water years 1995 through 2004. 


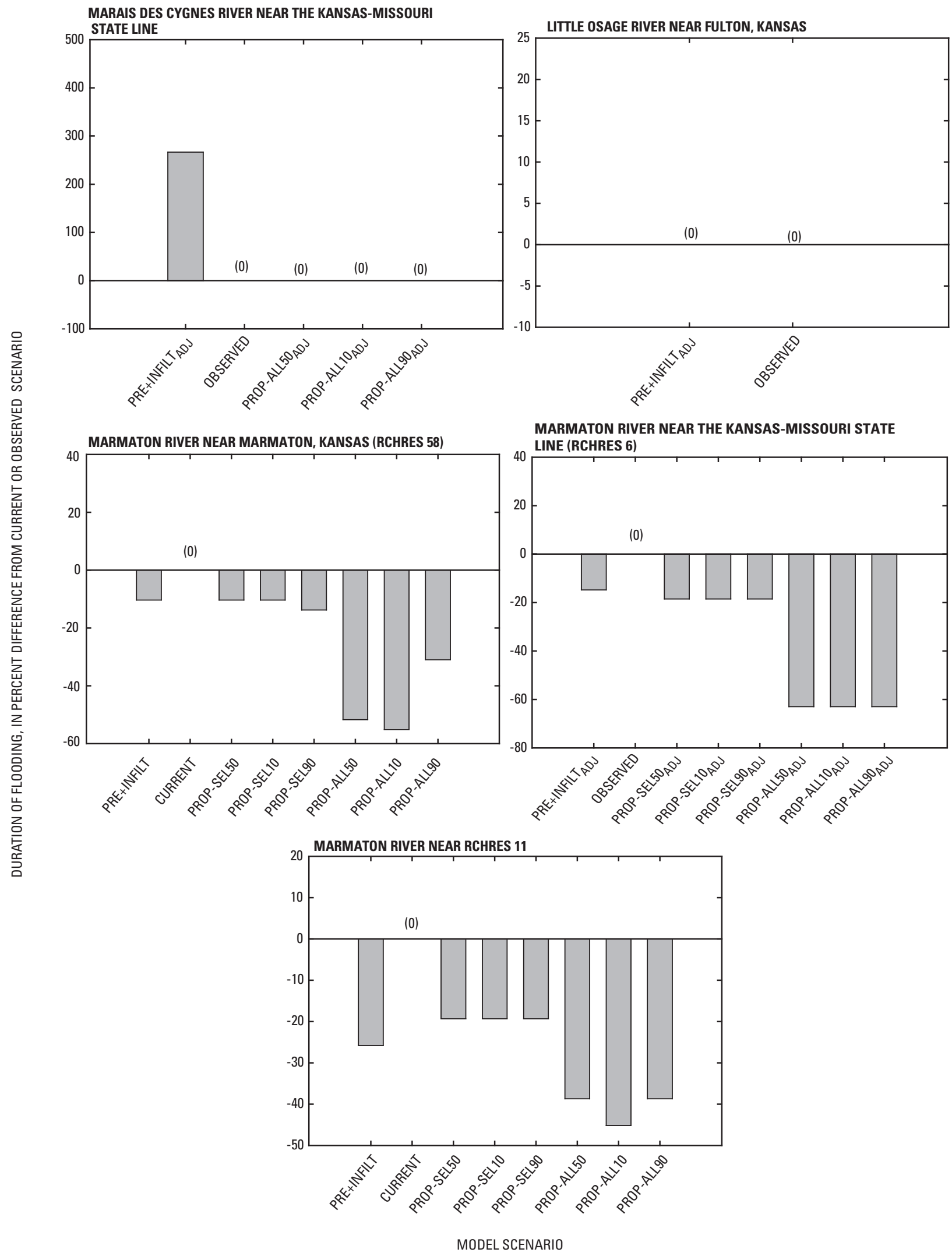

Figure 35. Differences in simulated flooding duration characteristics from Current simulated or Observed conditions, by model basin and scenario, water years 1995 through 2004. 


\section{Timing of Extreme Flows}

The timing of low and high flows also can be affected by impoundments, particularly those with controlled or managed releases. An alteration in the timing of low flows or peak flows can greatly affect stream channel and riparian biological processes including spawning of fishes, seed transport, and the germination of herbaceous and woody plants. The timing of floods during the 10-year simulation period in the model basins was not substantially affected by regulation, although the timing of low flow extremes was altered in some basins. At the Marais des Cygnes River near the Kansas-Missouri state line, Kansas, the timing of low flows along with small and large floods was similar between scenarios (table 19). The timing of Little Osage River extreme low flows was similar between pre-settlement and Observed flow scenarios, but Pre+infilt ${ }_{\text {adj }}$ large flood timing was in June rather than September, as for Observed flows (table 20). The timing of low flows and large floods at the Marmaton River near RCHRES 54 were similar between scenarios (table 21). At the Marmaton River near Marmaton, Kansas the timing of peak flows was similar between scenarios, but extreme low flows occurring in August for Pre+infilt ${ }_{\text {adj }}$ conditions and November for Observed and most proposed scenarios (table 22). The timing of low and high flows was similar under all scenarios at the Marmaton River near the Kansas-Missouri state line, Missouri (table 23).

\section{Effects of Impoundments and Land- Cover Changes on Selected Fish Habitat}

The effects of impoundments and land-cover changes within a basin can be quantified with changes in streamflow; however, another means of assessing the ecological consequences of altered conditions is through changes in in-stream habitat. The streamflow changes derived from the hydrologic models were used in conjunction with developed streamflowfish habitat relations (relations defining the quantity of fish habitat available for a given streamflow; Heimann and others, 2005) to provide a means of quantifying selected ecological effects of streamflow alteration on in-channel habitat in the Marais des Cygnes and Marmaton Rivers. Fish habitat area was not directly proportional to streamflow for most categories (Heimann and others, 2005) so habitat availability can be adversely affected by either declines or increases in streamflows.

Comparisons of 10-year daily habitat area distributions for nine selected fish species/life stage categories (table 17) under the varying streamflow simulation scenarios indicated that the effect of flow alteration on fish habitat varied by basin, scenario, time distribution, and fish species/life stage category. Of particular concern in comparing differ- ences in habitat by scenario were any possible declines in the minimum habitat availability that could lead to greater limiting conditions or "bottlenecks" in fish habitat availability and possible habitat declines of extended (7-14 days) durations.

Generally, the overall 10-year median fish habitat area in the Marais des Cygnes River for the selected habitat categories was similar between Observed and proposed scenarios at RCHRES 90, 93, and 95 (figs. 36-38; see fig. 12 for site locations; tables 29-31, on compact disc, at the back of this report). Exceptions included median suckermouth minnow habitat at sites RCHRES 90 and 95 that declined 3 (RCHRES 90) to 50 (RCHRES 95) square meters per 100 meters $\left(\mathrm{m}^{2} / 100 \mathrm{~m}\right)$ of stream channel under proposed conditions, slenderhead darter habitat at sites RCHRES 90 and 95 that declined about 2 to $10 \mathrm{~m}^{2} / 100 \mathrm{~m}$ under proposed conditions, and paddlefish habitat, which increased under proposed conditions relative to Observed conditions at all sites as much as $150 \mathrm{~m}^{2} / 100 \mathrm{~m}$.

Overall distributions of fish habitat area may be similar between simulation scenarios, but the annual distributions and comparisons during selected minimum availability periods provide a better indication of the habitat variability possible with time and between scenarios. The quantity of habitat availability and relative differences under Observed and Prop-all50 adj scenarios varied by water year. For example, habitat for paddlefish, whose habitat area is directly proportional to streamflow, varied substantially between wet (1999) and dry (2000) water years at RCHRES90; however, the relative differences in habitat availability between the two scenarios within a particular year also varied substantially (fig. 39). Of particular concern to managers are the habitat bottleneck periods and how such conditions are affected by flow alterations. Minimum annual 1-, 7-, or 14-day habitat availability for the prop-all50 ${ }_{\text {adj }}$ simulation declined at the Marais des Cygnes River by more than 10 percent compared with Observed conditions for 1 or more years for each of the nine seasonal fish habitat categories at each of the three Marais des Cygnes sites (figs. 40-42) indicating that habitat bottlenecks may be greater under proposed conditions for some categories for some seasons. Declines in minimum habitat availability were at or near 100 percent for 1 or more years for summer flathead catfish, fall flathead catfish, fall channel catfish, and fall stonecat habitat categories at RCHRES 93 (fig. 41) and for summer flathead catfish, summer channel catfish, and summer stonecat at RCHRES 95 (fig. 42). This indicates that habitat for these categories may be eliminated for 1 to 14 days during some part of some years under proposed conditions.

Overall, median habitat area for paddlefish increased substantially ( 120 to $600 \mathrm{~m}^{2} / 100 \mathrm{~m}$ ) between pre-settlement and Observed conditions at the Marais des Cygnes RCHRES 90, 93, and 95 sites, whereas summer and fall flathead catfish, summer channel catfish, and summer and fall stonecat habitat generally increased ( 1 to $60 \mathrm{~m}^{2} / 100 \mathrm{~m}$ ) with slower recession hydrographs under Observed conditions (fig. 36-38; tables 


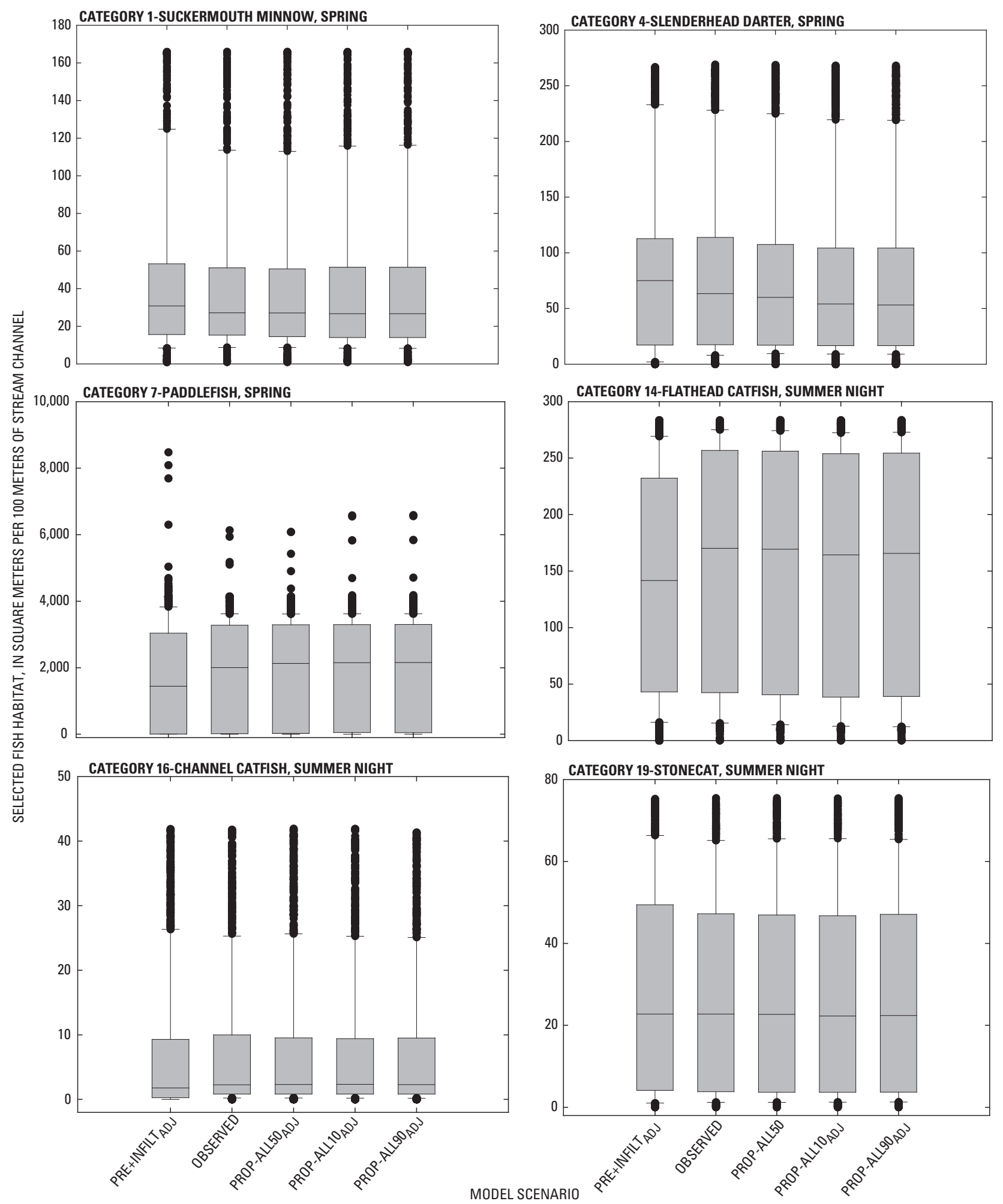

Figure 36. Distribution of daily fish habitat for select categories at the Marais des Cygnes River RCHRES 90, water years 1995 through 2004. 

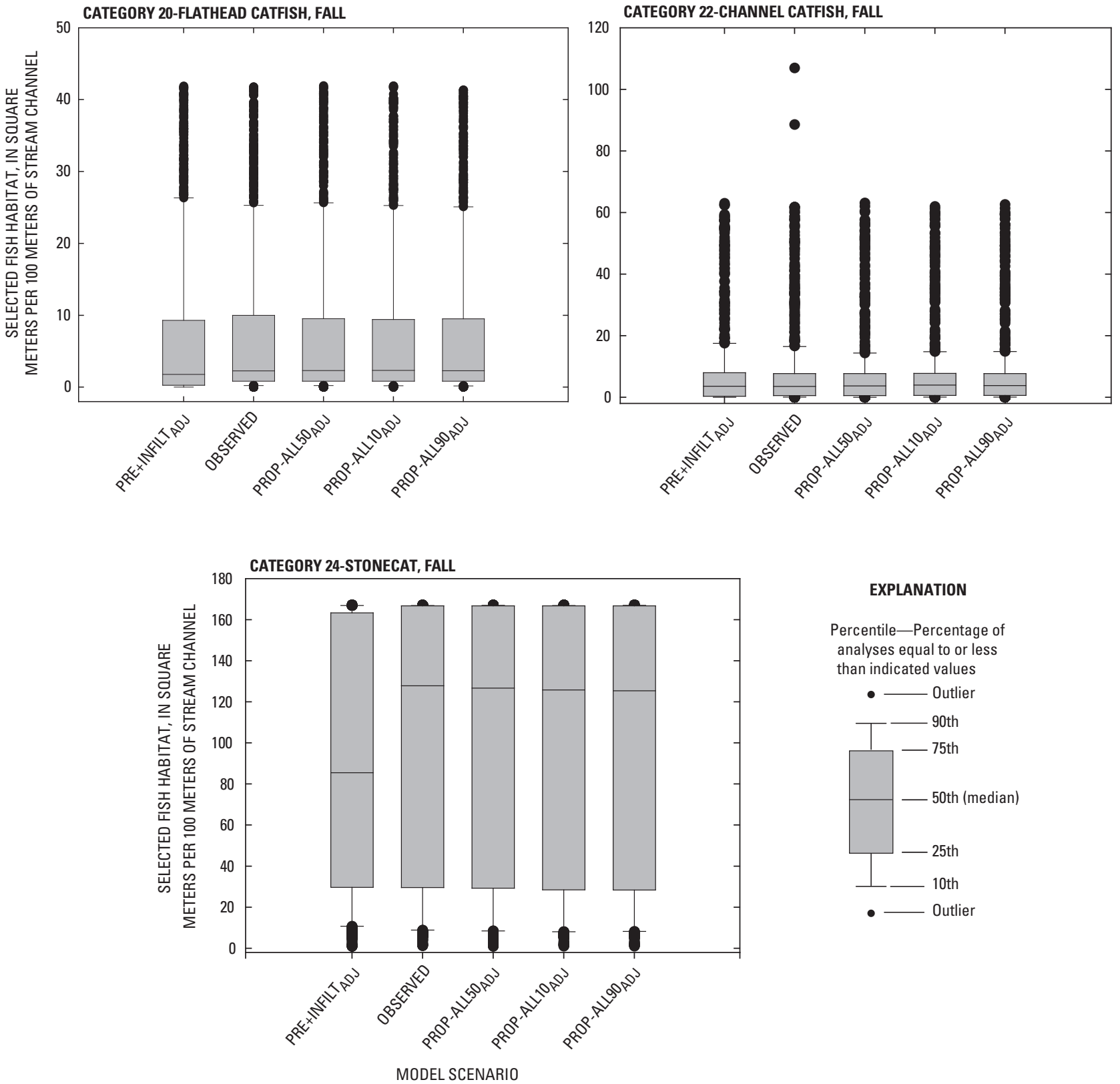

Figure 36. Distribution of daily fish habitat for select categories at the Marais des Cygnes River RCHRES 90, water years 1995 through 2004.-Continued 


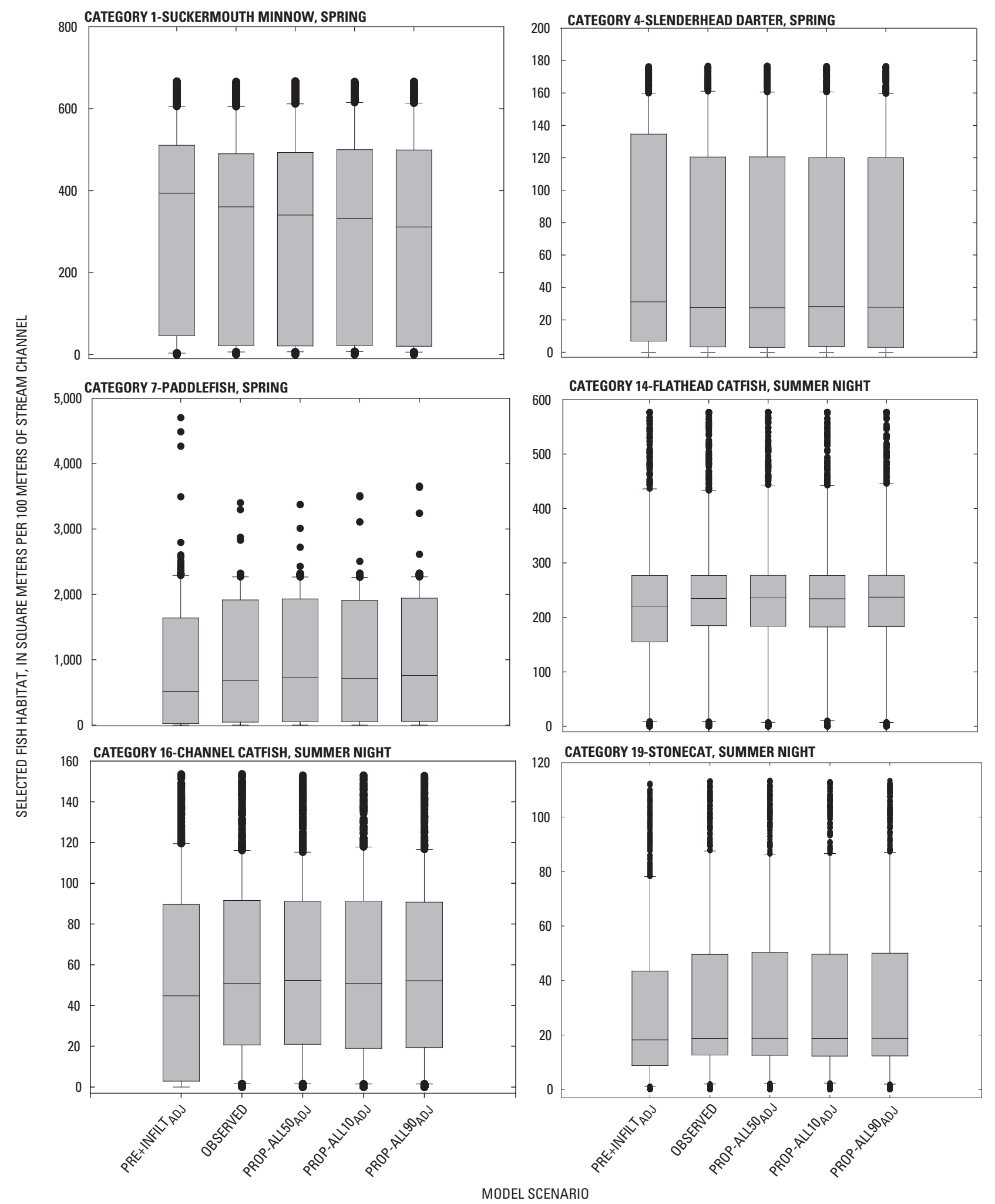

Figure 37. Distribution of daily fish habitat for select categories at the Marais des Cygnes River RCHRES 93, water years 1995 through 2004. 

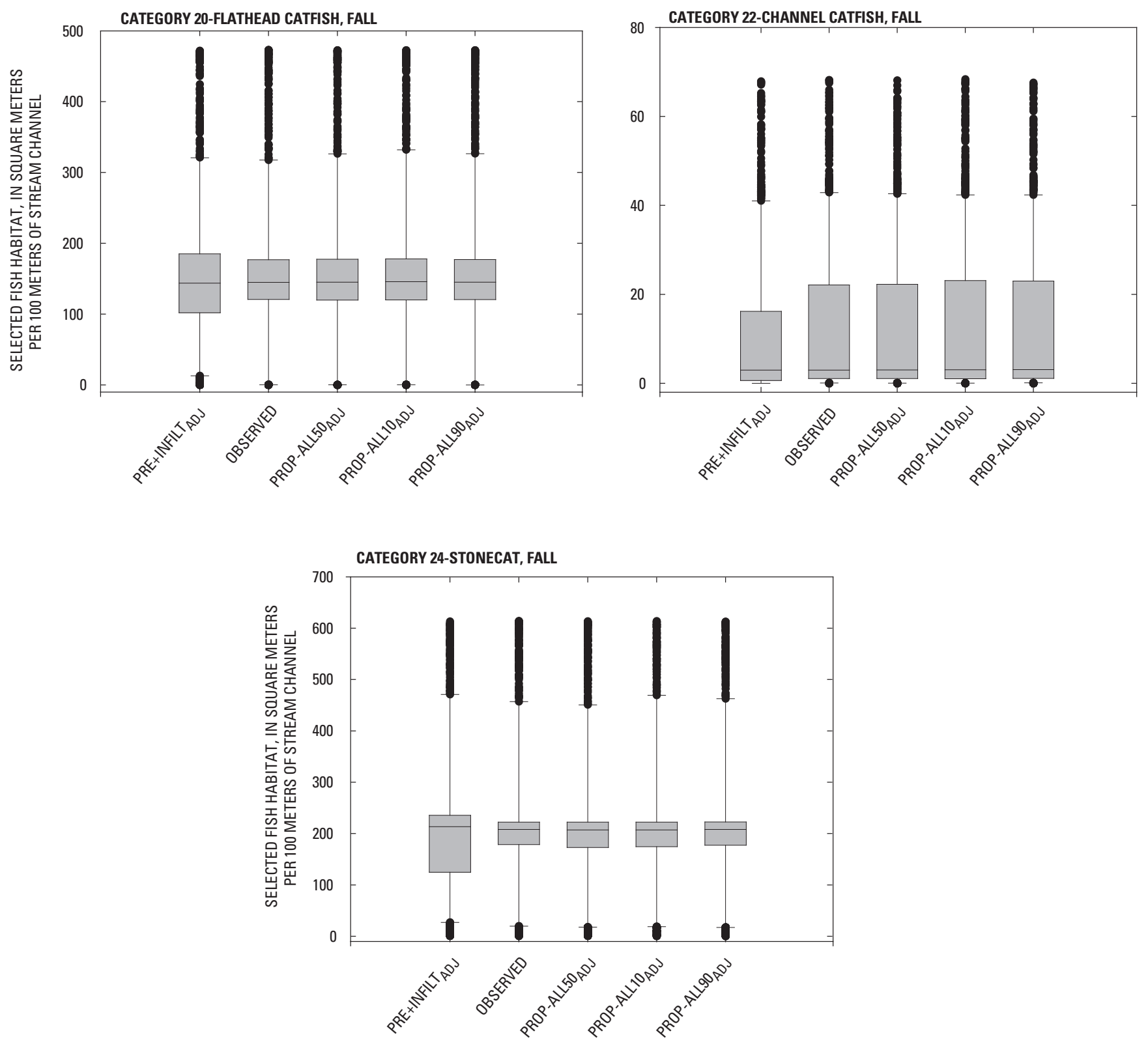

Figure 37. Distribution of daily fish habitat for select categories at the Marais des Cygnes River RCHRES 93, water years 1995 through 2004.-Continued 

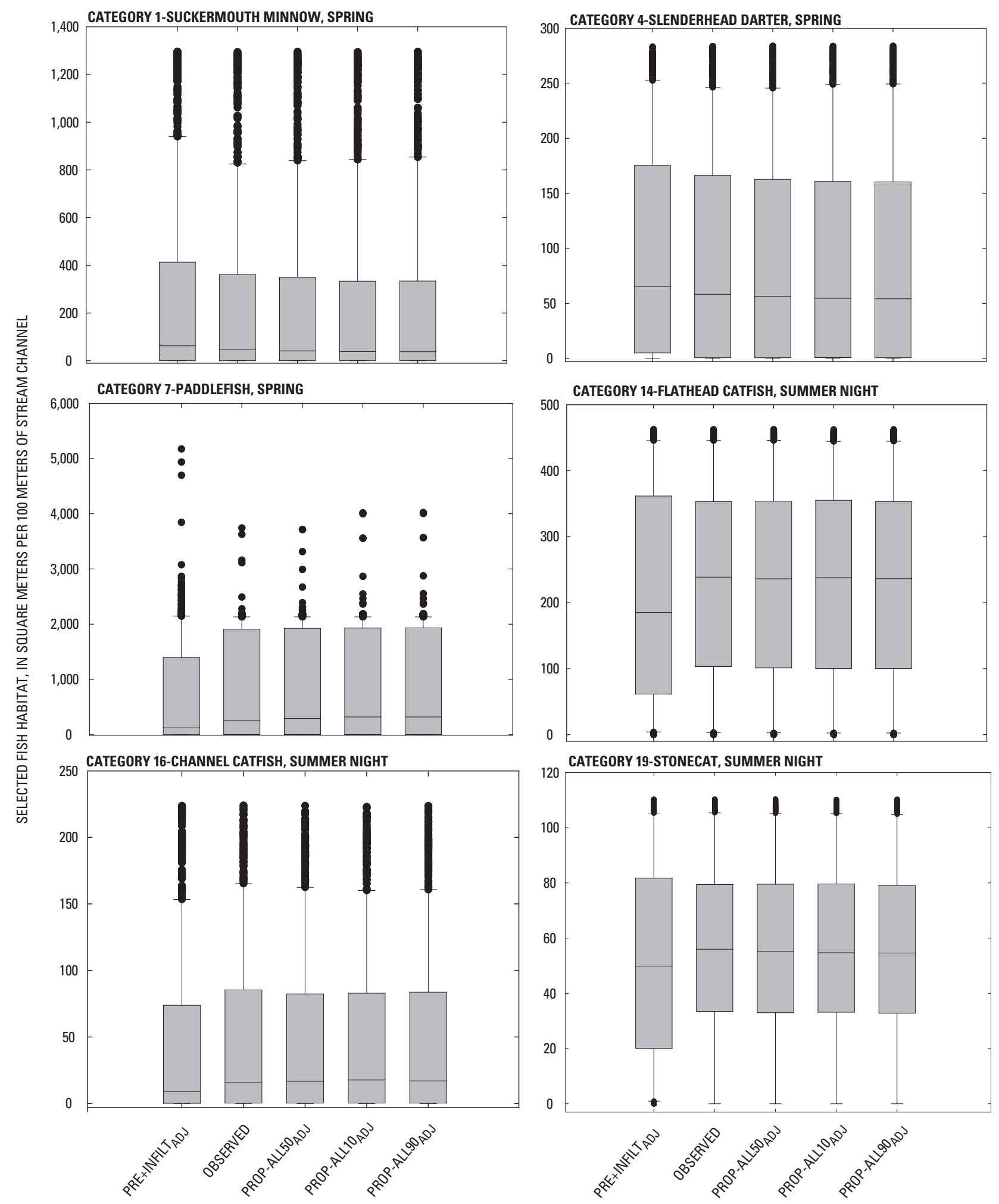

Figure 38. Distribution of daily fish habitat for select categories at the Marais des Cygnes River RCHRES 95, water years 1995 through 2004. 

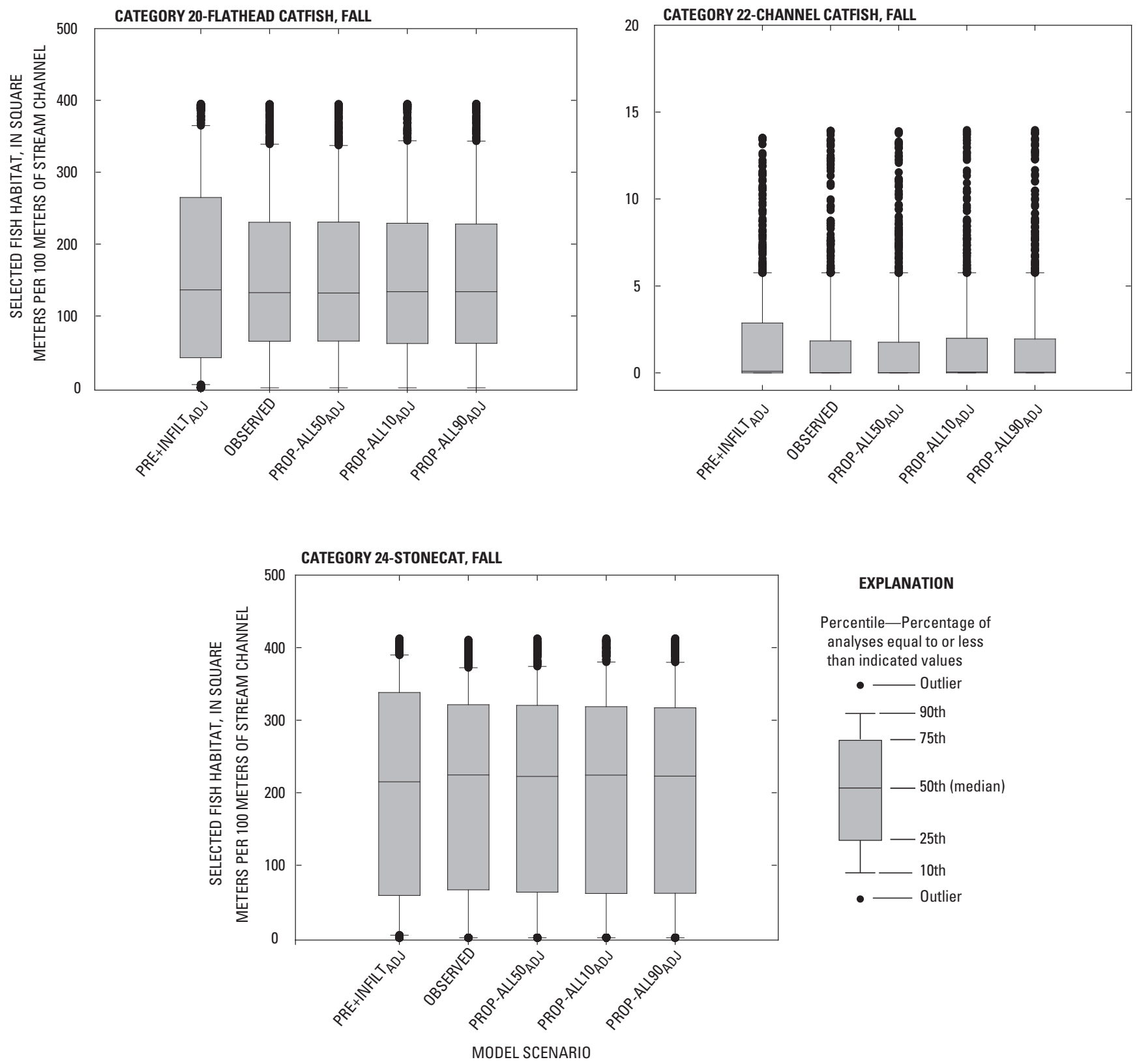

EXPLANATION

Percentile-Percentage of

analyses equal to or less

than indicated values
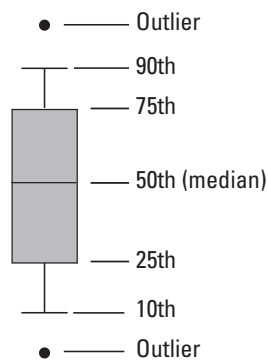

Figure 38. Distribution of daily fish habitat for select categories at the Marais des Cygnes River RCHRES 95, water years 1995 through 2004.-Continued 

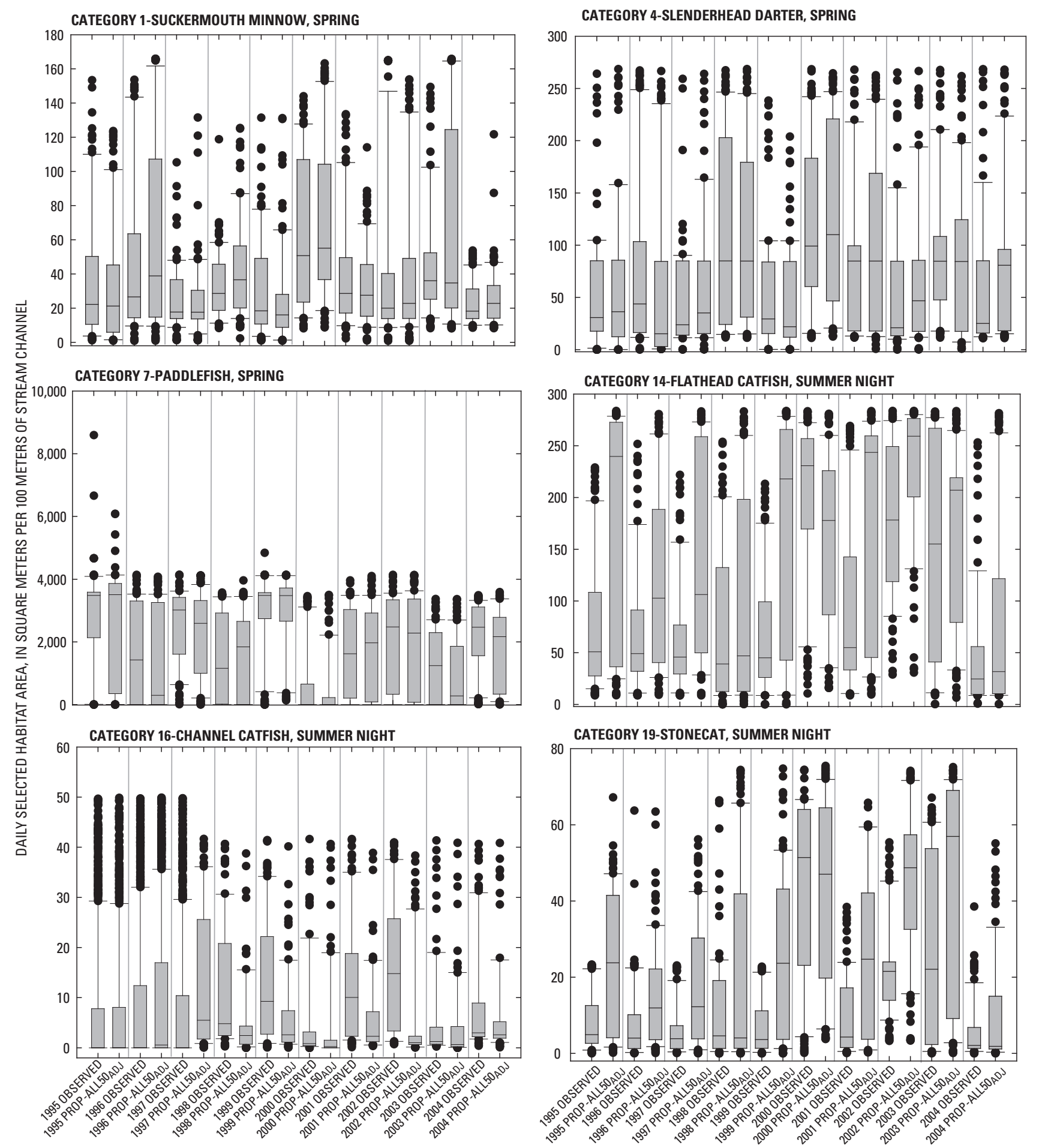

Figure 39. Comparison of distributions of daily fish habitat for Observed and Prop-all50 ${ }_{\text {adj }}$ streamflow scenarios, by year and select species/life stage categories, at the Marais des Cygnes River RCHRES 90, water years 1995 through 2004. 


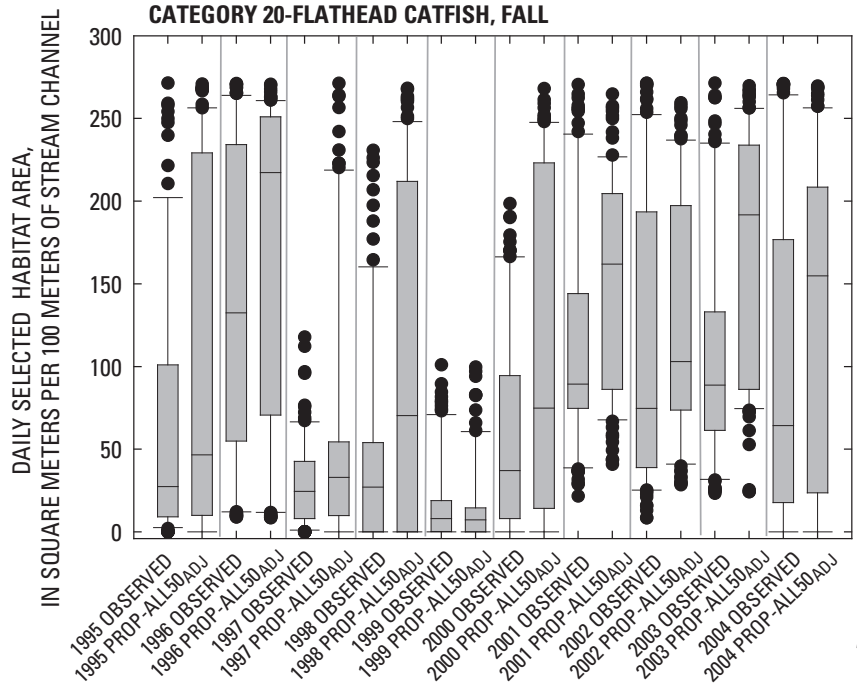

CATEGORY 22- CHANNEL CATFISH, FALL
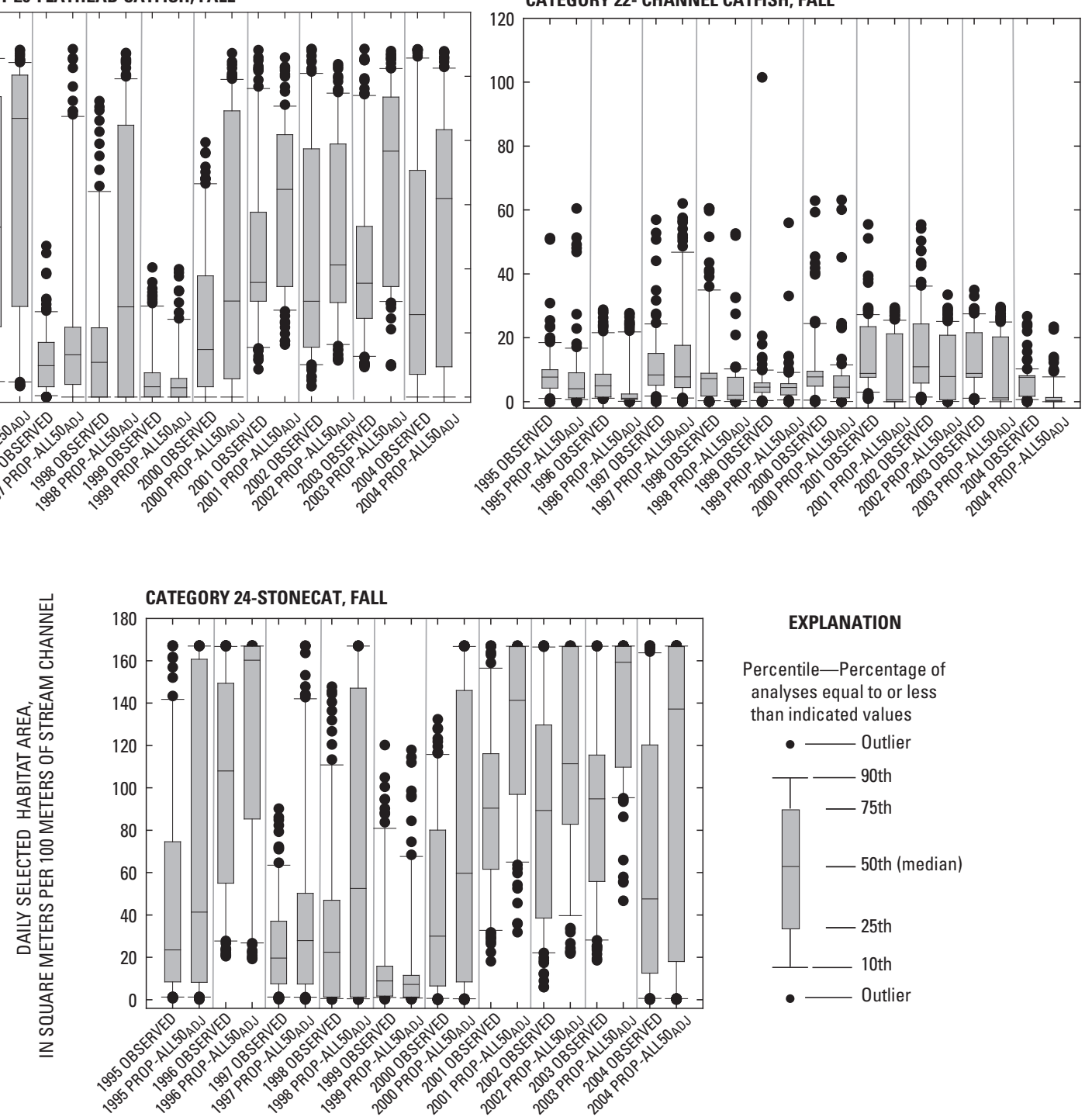

EXPLANATION

Percentile-Percentage of analyses equal to or less than indicated values
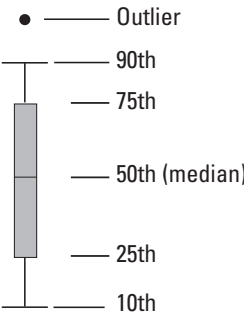

- - Outlier

Figure 39. Comparison of distributions of daily fish habitat for Observed and Prop-all50 adi streamflow scenarios, by year and select species/life stage categories, at the Marais des Cygnes River RCHRES 90, water years 1995 through 2004.—Continued 


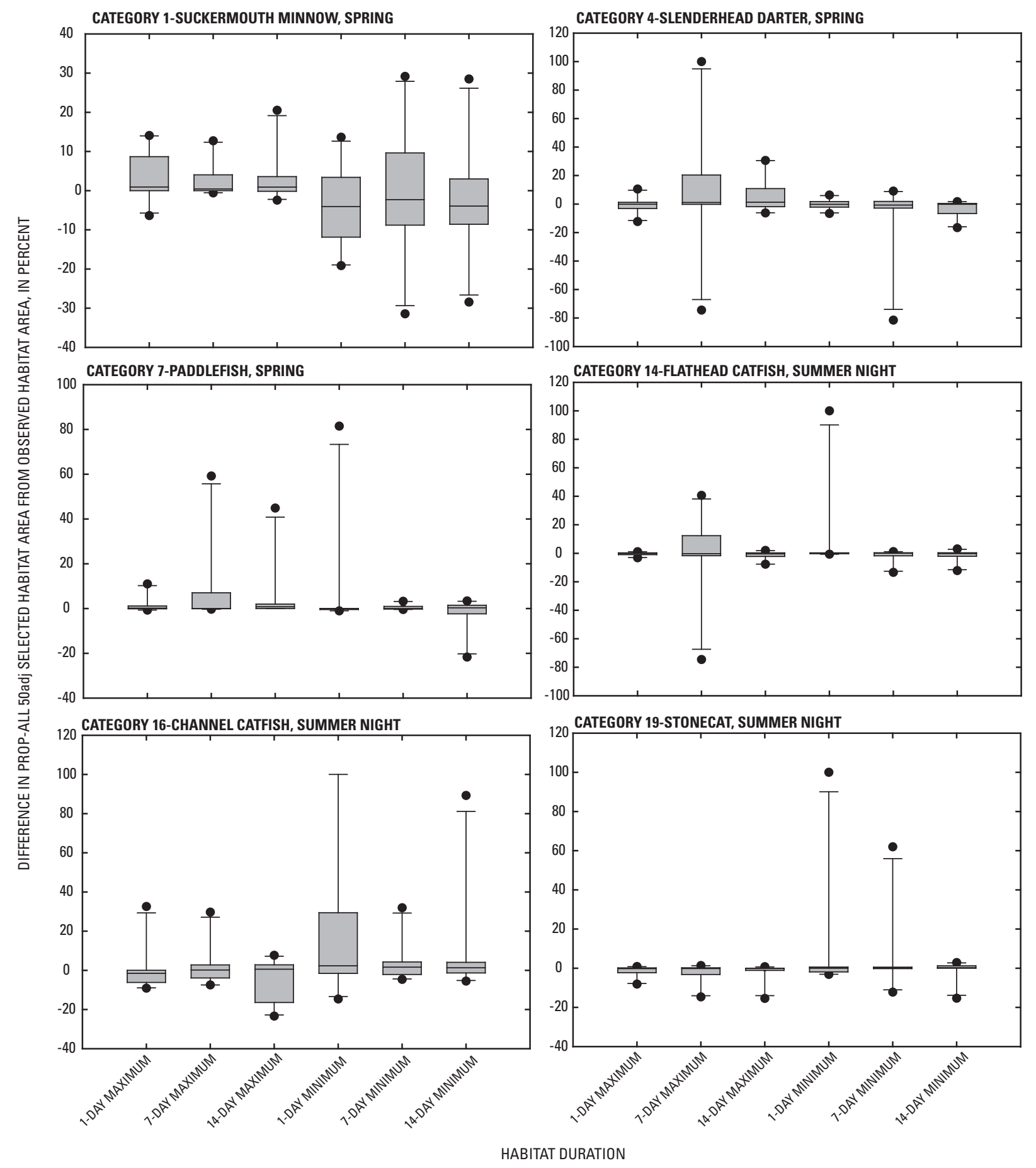

Figure 40. Distribution of percent differences between Prop-all50 ${ }_{\text {adi }}$ and Observed fish habitat conditions for 1-, 7-, and 14-day maximum and minimum durations, by selected species/life stage categories, at the Marais des Cygnes River RCHRES 90, water years 1995 through 2004. 

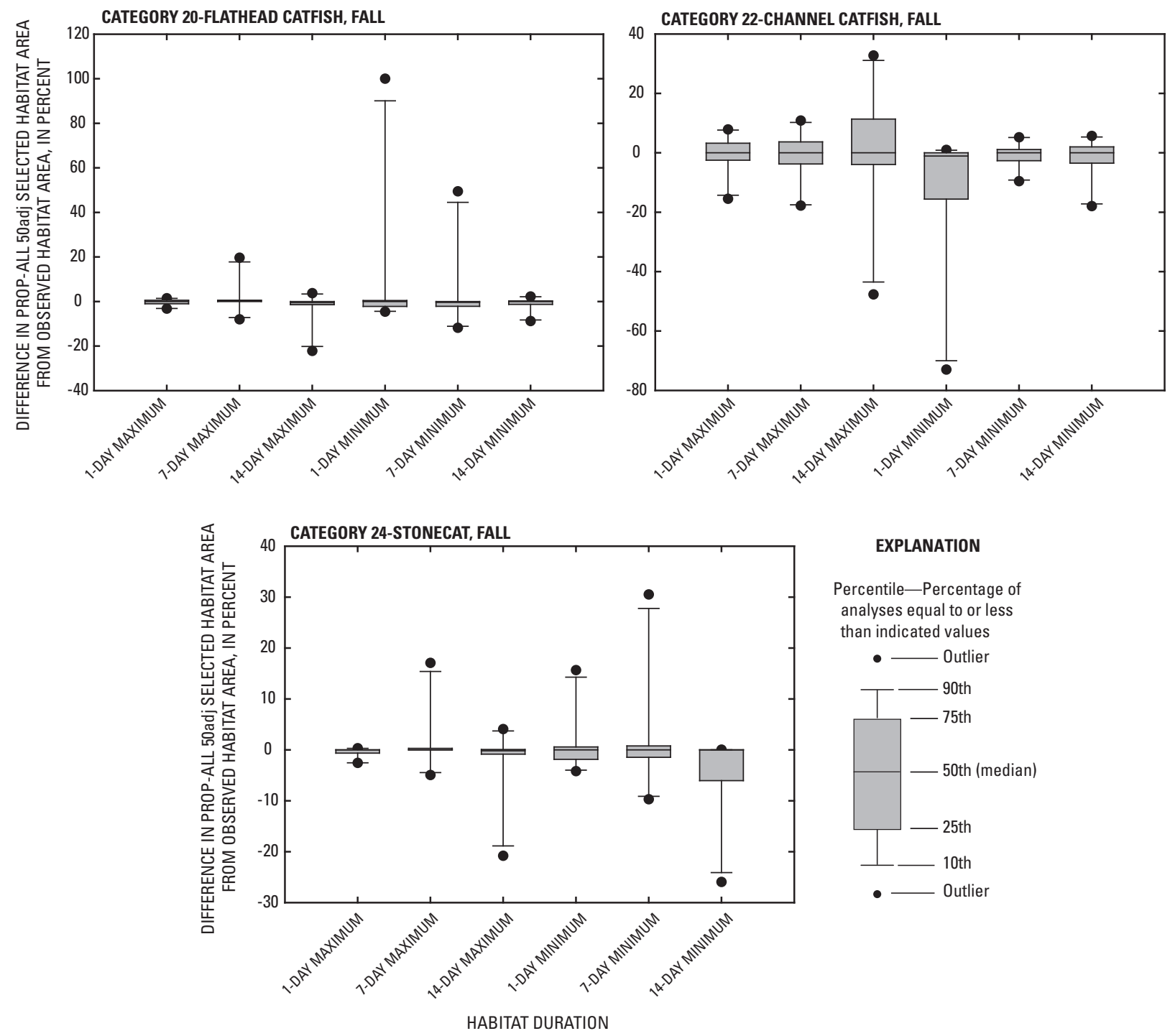

EXPLANATION

Percentile-Percentage of analyses equal to or less than indicated values

- Outlier

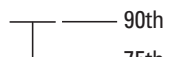

- 75th

— 50th (median)

-25th

1 10th

- - Outlier

Figure 40. Distribution of percent differences between Prop-all50 $0_{\text {adj }}$ and 0 bserved fish habitat conditions for 1-, 7-, and 14-day maximum and minimum durations, by selected species/life stage categories, at the Marais des Cygnes River RCHRES 90, water years 1995 through 2004.-Continued 


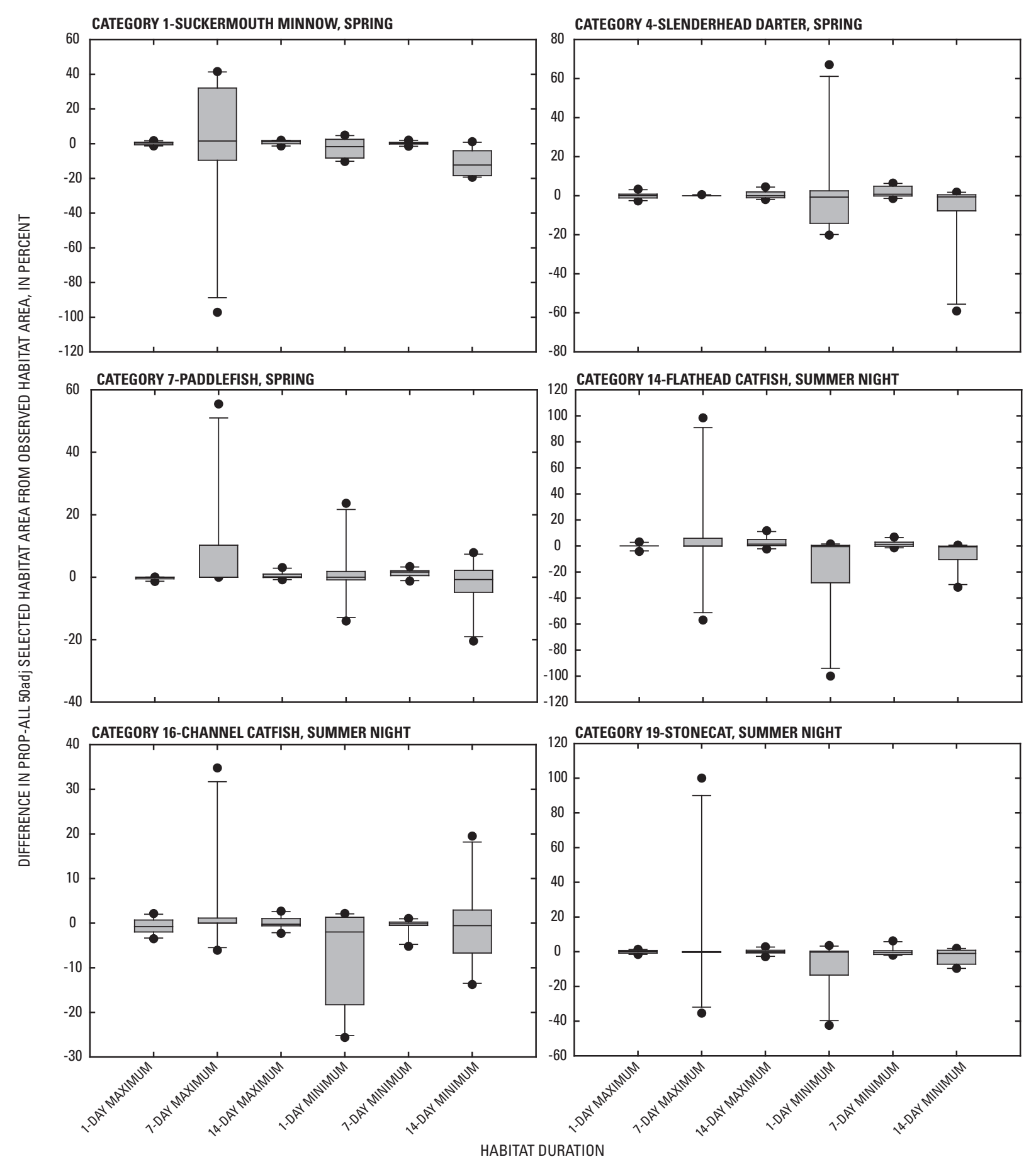

Figure 41. Distribution of percent differences between Prop-all50 adj and Observed fish habitat conditions for 1-, 7-, and 14-day maximum and minimum durations, by selected species/life stage categories, at the Marais des Cygnes River RCHRES 93, water years 1995 through 2004. 

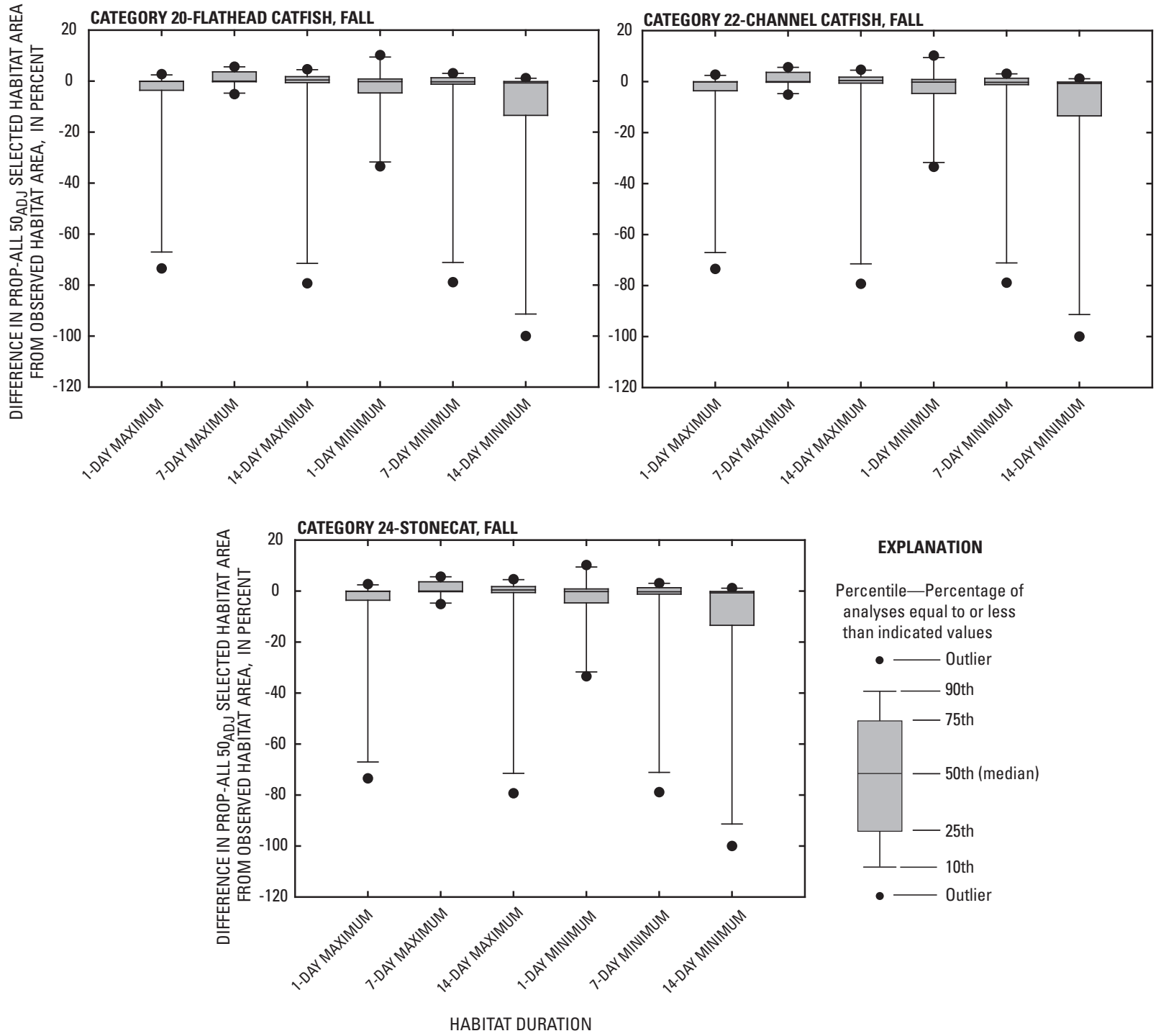

EXPLANATION

Percentile-Percentage of analyses equal to or less than indicated values - Outlier

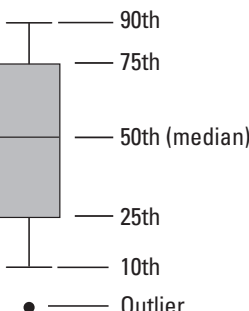

Figure 41. Distribution of percent differences between Prop-all50 adj and Observed fish habitat conditions for 1-, 7-, and 14-day maximum and minimum durations, by selected species/life stage categories, at the Marais des Cygnes River RCHRES 93, water years 1995 through 2004.-Continued 


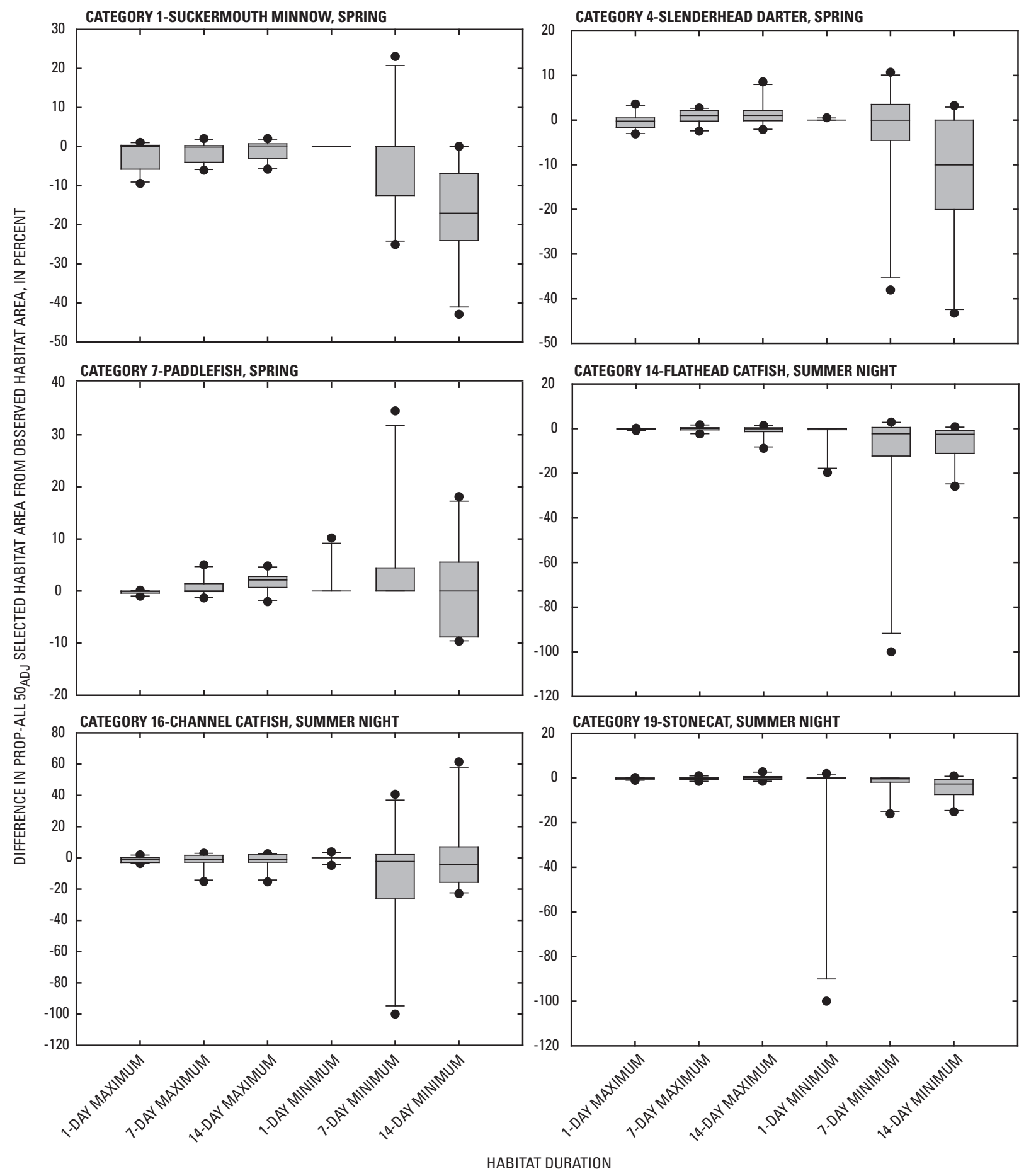

Figure 42. Distribution of percent differences between Prop-all50 ${ }_{\text {adj }}$ and Observed fish habitat conditions for 1-, 7-, and 14-day maximm and minimum durations, by selected species/life stage categories, at the Marais des Cygnes River RCHRES 95, water years 1995 through 2004. 

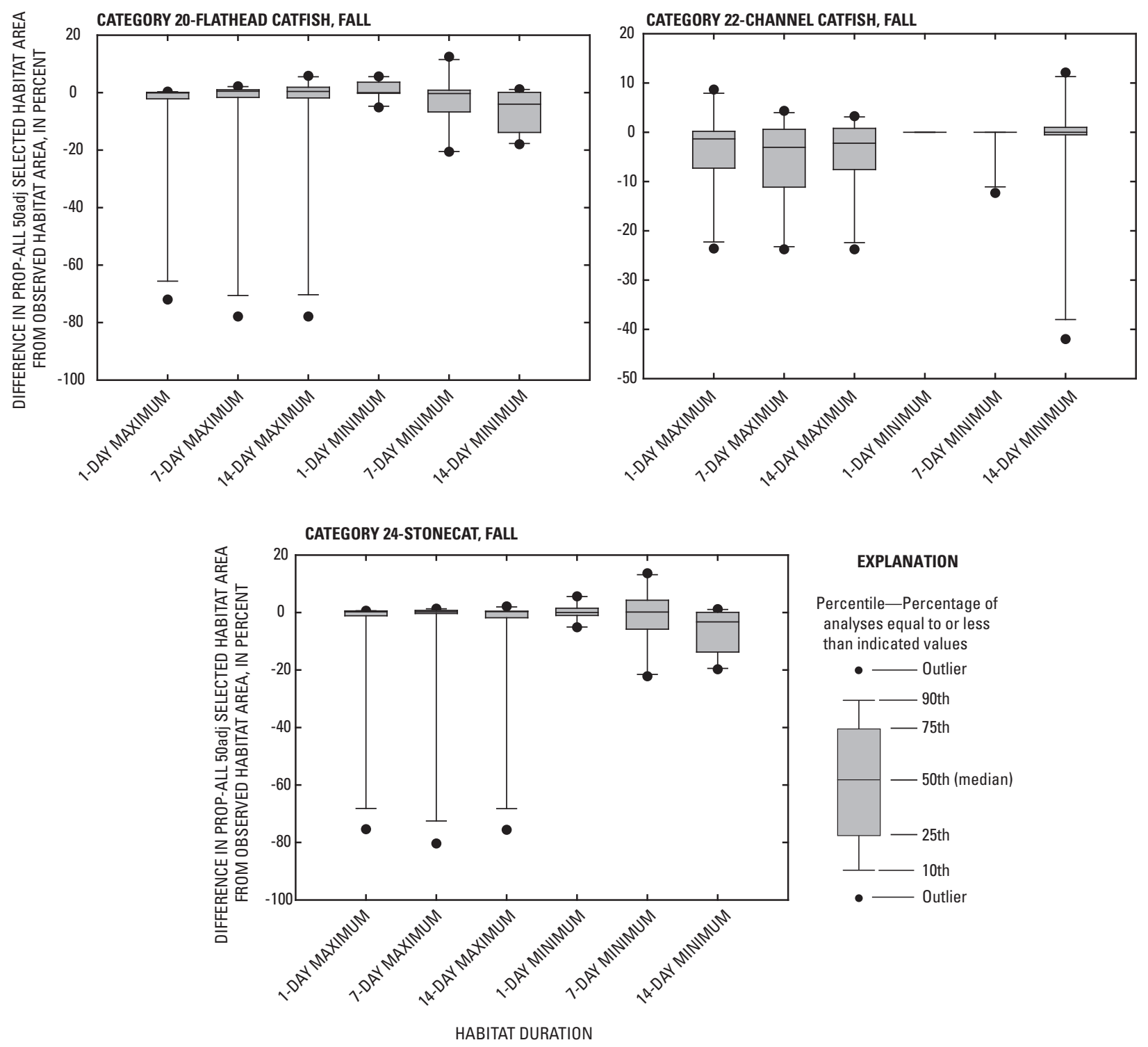

Figure 42. Distribution of percent differences between Prop-all $50_{\text {adj }}$ and Observed fish habitat conditions for 1-, 7-, and 14-day maximm and minimum durations, by selected species/life stage categories, at the Marais des Cygnes River RCHRES 95, water years 1995 through 2004.-Continued 
29-31). Median paddlefish habitat increased substantially between pre-settlement and Observed scenarios, but maximum paddlefish habitat availability was greatest under unregulated pre-settlement conditions at all three locations (figs. 36-38; tables 29-31) as unregulated peak flows were greater. Overall median suckermouth minnow habitat declined 3 to 30 $\mathrm{m}^{2} / 100 \mathrm{~m}$, and slenderhead darter habitat declined between 3 and $7 \mathrm{~m}^{2} / 100 \mathrm{~m}$ from pre-settlement to Observed conditions, depending on location.

Overall, median paddlefish habitat area increased ( 0 to $170 \mathrm{~m}^{2} / 100 \mathrm{~m}$ ) between current and proposed conditions at the Marmaton River at the Kansas-Missouri state line, Missouri (RCHRES 6), and downstream Marmaton River RCHRES 11 sites; however, median habitat generally decreased for suckermouth minnow ( 2 to $13 \mathrm{~m}^{2} / 100 \mathrm{~m}$ ), slenderhead darter ( 0 to $\left.20 \mathrm{~m}^{2} / 100 \mathrm{~m}\right)$, summer flathead catfish (0 to $\left.44 \mathrm{~m}^{2} / 100 \mathrm{~m}\right)$, and summer stonecat (0 to $10 \mathrm{~m}^{2} / 100 \mathrm{~m}$ ) categories (figs. 43 , 44; tables 32 and 33, on compact disc, at the back of this report). Habitat for the remaining categories was similar between Current and proposed conditions.

The annual quantity of fish habitat varied by water year at the Marmaton River near state line, Missouri, but the relative differences between Current and Prop-all50 scenarios were less variable than the annual changes, and differences were more consistent than those at the Marais des Cygnes RCHRES 90 site. Habitat generally declined under the Prop-all50 scenario compared with current conditions (fig. 45); this relation was more consistent between years and categories than at the Marais des Cygnes River RCHRES 90 site (fig. 39). One possible explanation for the greater habitat variability between scenarios at the Marais des Cygnes site than at the Marmaton River site is the greater complexity in channel geometry resulting from secondary levels of in-channel substrate deposits leading to a greater variability in habitat-streamflow relations (Heimann and others, 2005). Declines in annual 1-, 7-, or 14-day minimum habitat were greater than 10 percent for 1 or more years for all categories at both Marmaton River locations, except for spring paddlefish habitat at RCHRES 6, which generally remained unchanged between Current and proposed scenarios (figs. 46-47). Declines in 1-, 7-, or 14-day proposed minimum habitat availability were at or near 100 percent for 1 or more years for slenderhead darter, summer flathead catfish, fall channel catfish, and fall stonecat habitat categories at RCHRES 6 and for spring suckermouth minnow, spring slenderhead darter, summer channel catfish, summer stonecat, and fall flathead catfish habitat at RCHRES 11 (figs. 46-47).

Generally, overall median habitat area for suckermouth minnow ( 2 to $7 \mathrm{~m}^{2} / 100 \mathrm{~m}$ ), summer and fall flathead catfish (summer 4 to $28 \mathrm{~m}^{2} / 100 \mathrm{~m}$, fall 0 to $9 \mathrm{~m}^{2} / 100 \mathrm{~m}$ ), fall channel catfish (0 to $\left.3 \mathrm{~m}^{2} / 100 \mathrm{~m}\right)$ and fall stonecat (0 to $13 \mathrm{~m}^{2} / 100$ $\mathrm{m}$ ) habitat declined from pre-settlement to Current conditions at the two Marmaton River reporting locations (figs. 43, 44; tables 32, 33). Median paddlefish habitat increased 1 to $10 \mathrm{~m}^{2} / 100 \mathrm{~m}$ from pre-settlement to Current conditions at the RCHRES 11 location, but remained unchanged at the
RCHRES 6 location. Maximum paddlefish habitat area was greater for Current simulated conditions at both Marmaton River locations compared with pre-settlement conditions (figs. 43, 44; tables 32, 33).

Simulations indicate that alterations in streamflow have resulted in substantial changes in the availability of habitat in the Marais des Cygnes and Maramton Rivers between presettlement and present-day conditions and through possible proposed conditions. These changes in habitat availability under various simulated flow conditions can be quantified, and are shown to vary with fish species, life stage, season, and year-to-year flow variability.

\section{Summary and Conclusions}

This report summarizes results from a study to estimate the effects of impoundments, land-cover changes, and reported point-source withdrawals and discharges on streamflows in the 5,410-square mile upper Osage River Basin in Missouri and Kansas. Hydrologic models developed using the Hydrologic Simulation Program-FORTRAN were calibrated and validated to current (1995-2004 water years) regulation and water-use conditions, and modified to simulate changes in regulation and water-use conditions under pre-settlement and proposed-regulation conditions for the same period of record. Analyses included quantification of changes in the magnitude, frequency, duration, and timing of streamflows under each scenario. Output from simulation scenarios were used in conjunction with known streamflow-fish habitat relations to quantify effects of altered flow on fish habitat area.

Analyses of simulated runoff and evapotranspiration for the Marmaton River Basin (1995 through 2004 water years) provided an indication of the effects of land-cover and regulation changes on the water balance in the study basins. The change from historical land cover to current land cover resulted in a decline of 120 thousand acre-feet of total runoff, indicating that the combined land-cover changes (100 thousand acre-feet) and net water use losses (20-thousand acre feet) might have a greater effect on total runoff than impoundments. The effects of a conversion of cultivated row crops back to pre-settlement native prairie soils were simulated using an increase in the infiltration model parameter for the pre-settlement prairie/rangeland land cover. This parameter modification accounted for a greater difference in total runoff between pre-settlement and current/proposed scenarios than other changes in land cover or from impoundments. The simulated increase in soil infiltration capacity under native prairie conditions also resulted in lower peak flows for the pre-settlement model scenario compared with current/proposed scenarios. Impoundments decreased hydrograph peaks and extended the recession limb of the hydrographs in the simulations; increased infiltration had similar effects. Evapotranspiration from the land and open-water surfaces varied little between current and proposed scenarios, but could account for differ- 

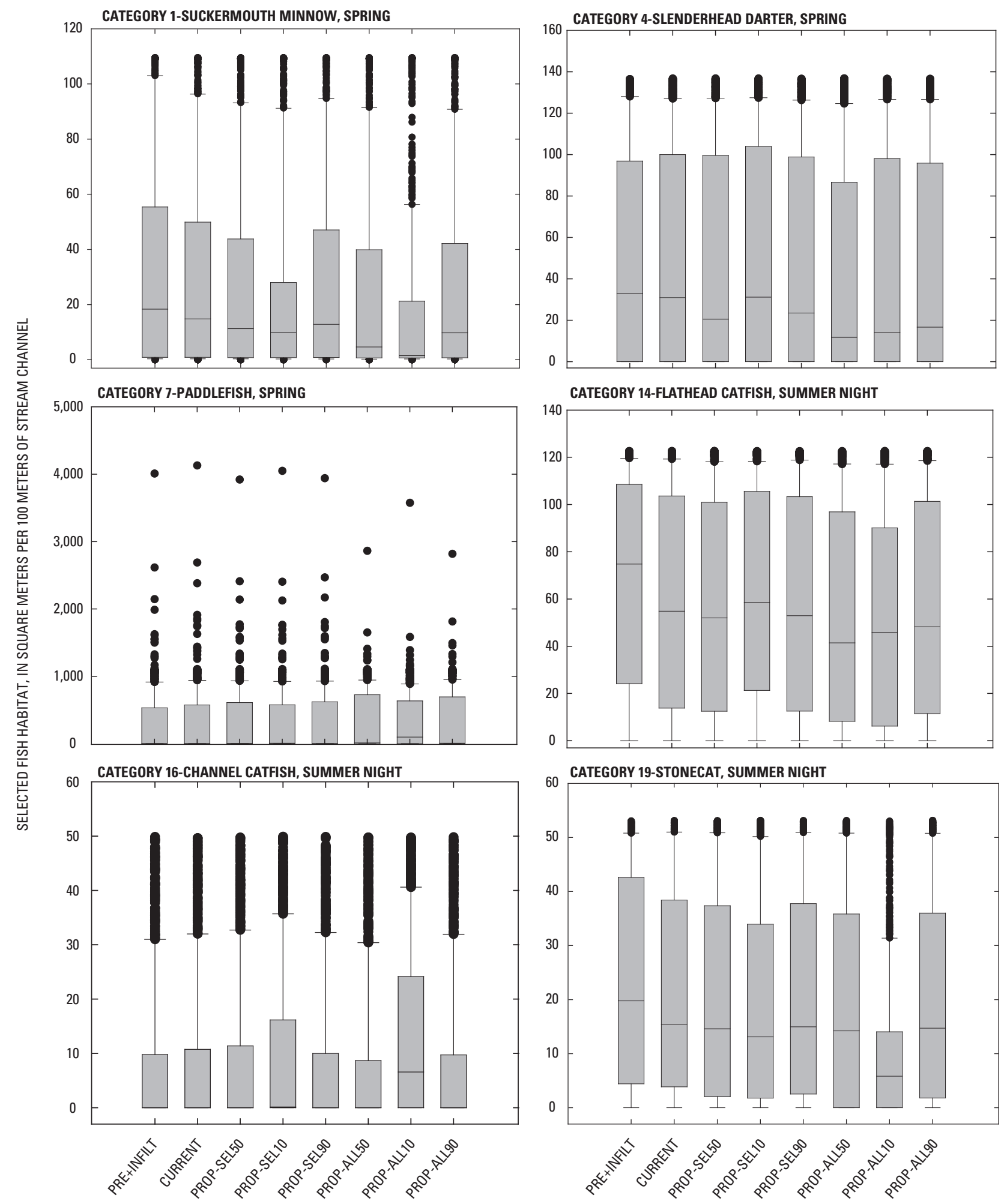

MODEL SCENARIO

Figure 43. Distribution of daily fish habitat, by streamflow scenario and selected species/life stage categories, at the the Marmaton River near the Kansas-Missouri state line, Missouri (RCHRES 6), water years 1995 through 2004. 

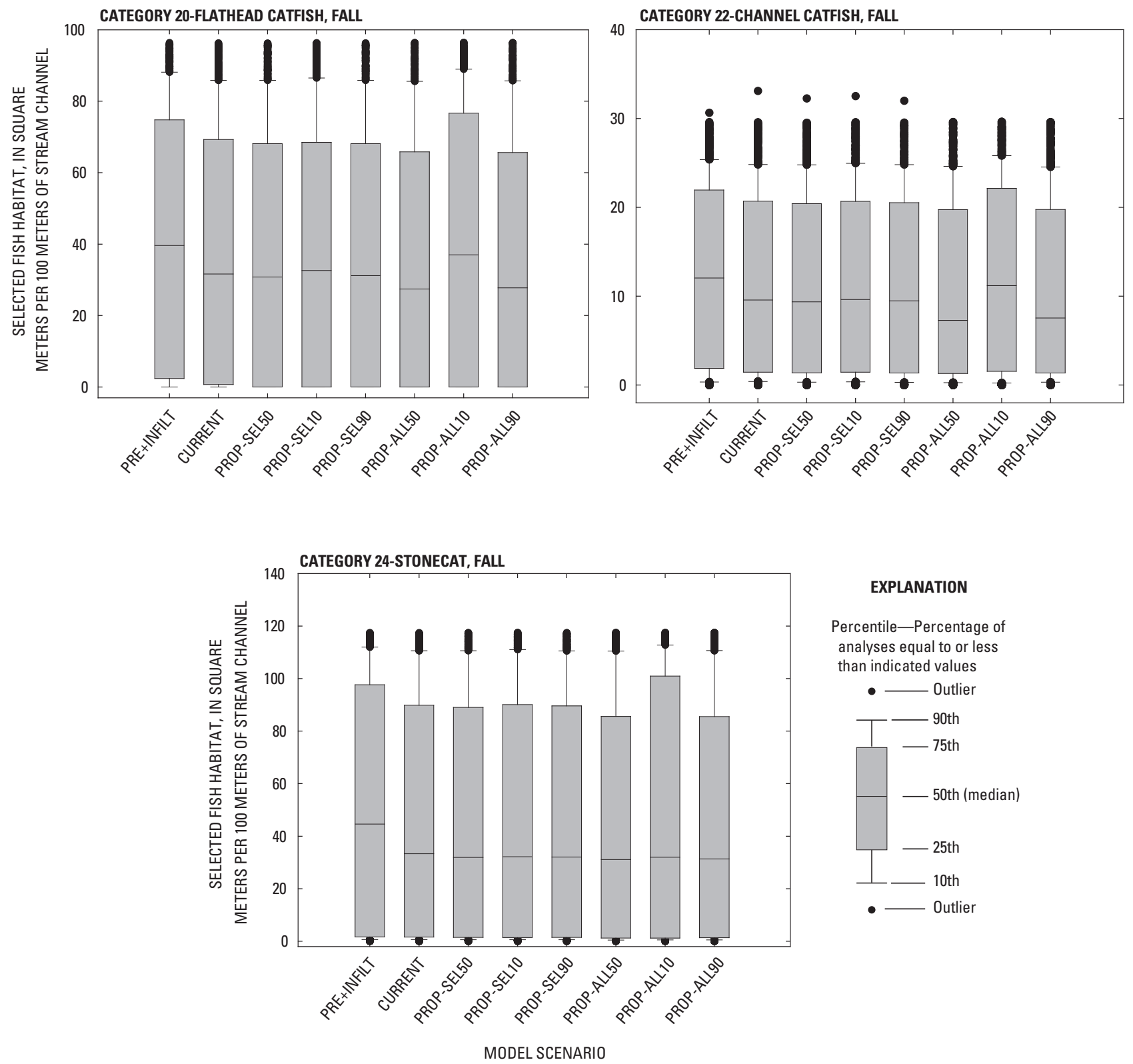

EXPLANATION

Percentile-Percentage of

analyses equal to or less

than indicated values

- Outlier

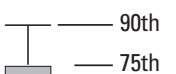

- 50th (median)
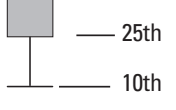

- Outlier

Figure 43. Distribution of daily fish habitat, by streamflow scenario and selected species/life stage categories, at the the Marmaton River near the Kansas-Missouri state line, Missouri (RCHRES 6), water years 1995 through 2004._Continued 

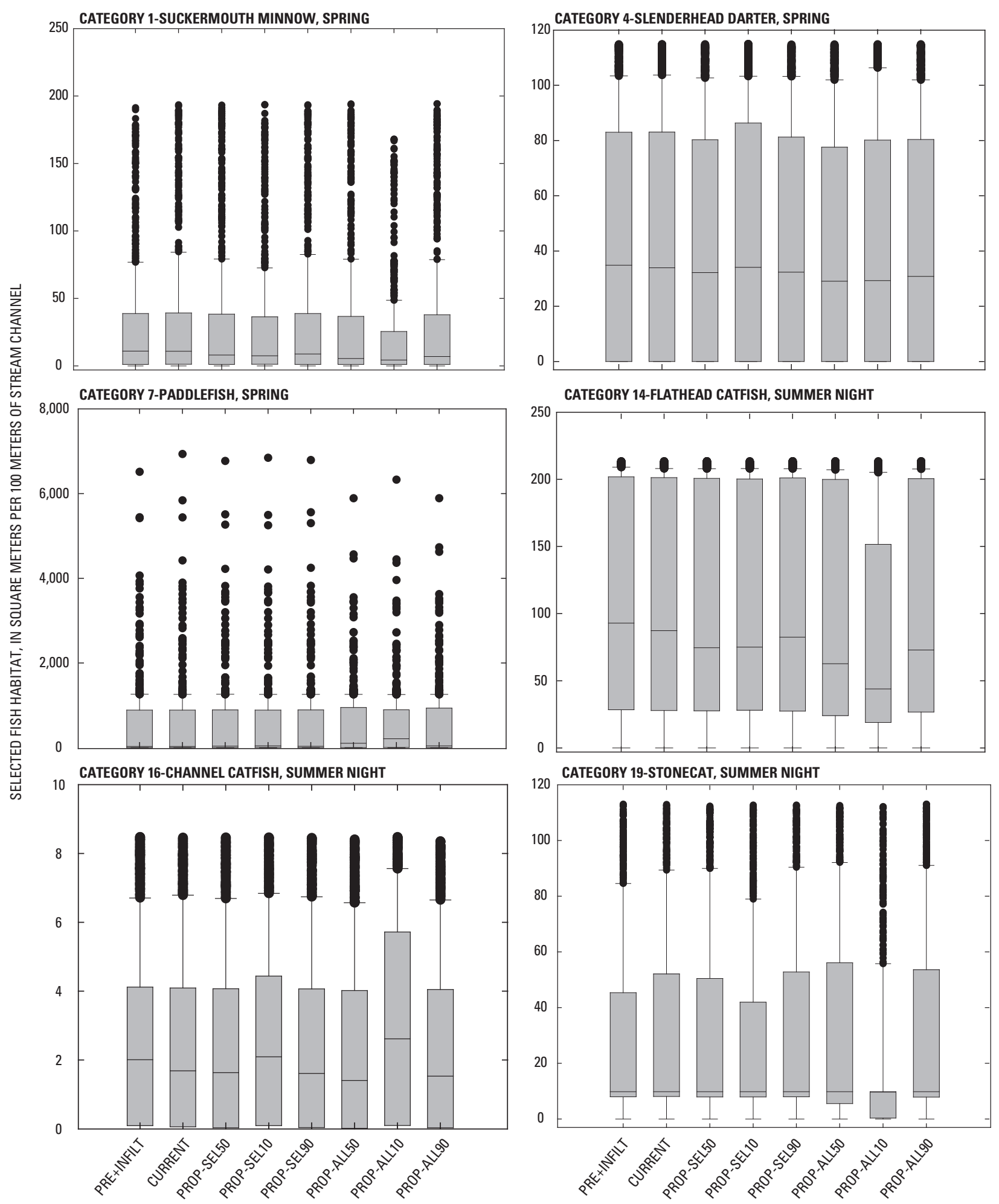

MODEL SCENARIO

Figure 44. Distribution of daily fish habitat, by streamflow scenario and selected species/life stage categories, at the Marmaton River RCHRES 11, water years 1995 through 2004. 

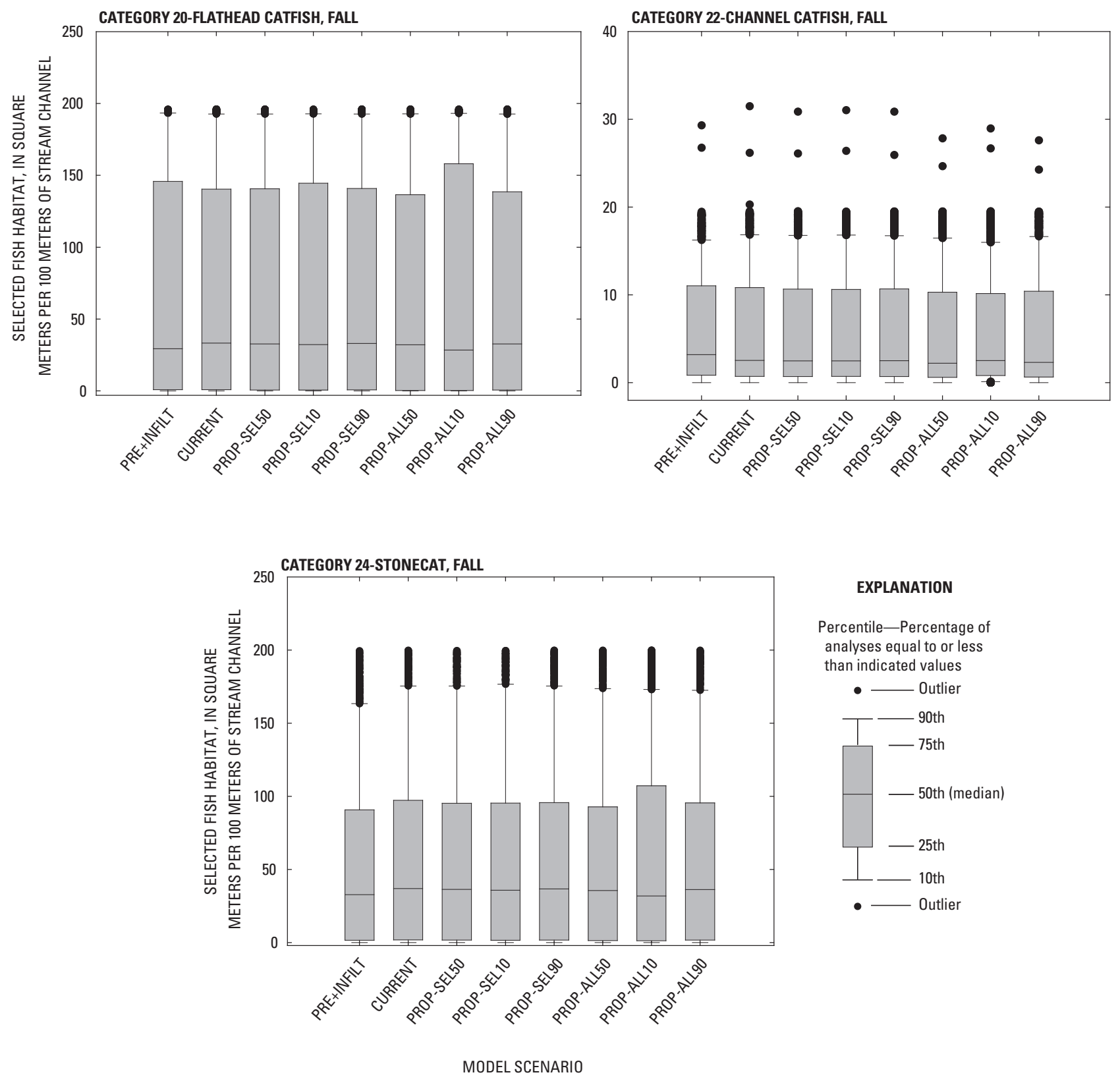

Figure 44. Distribution of daily fish habitat, by streamflow scenario and selected species/life stage categories, at the Marmaton River RCHRES 11, water years 1995 through 2004.-Continued 
CATEGORY 1-SUCKERMOUTH MINNOW, SPRING

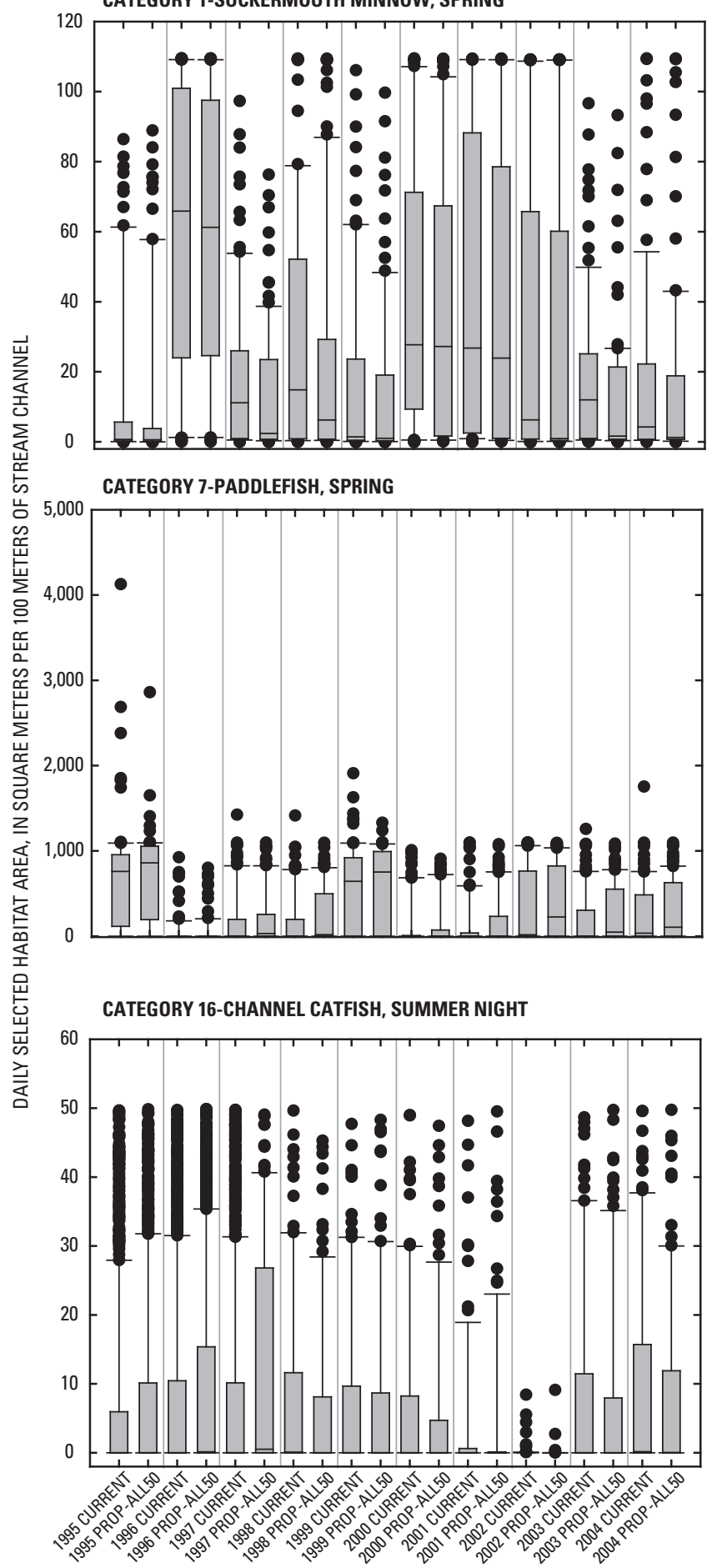

CATEGORY 4-SLENDERHEAD DARTER, SPRING
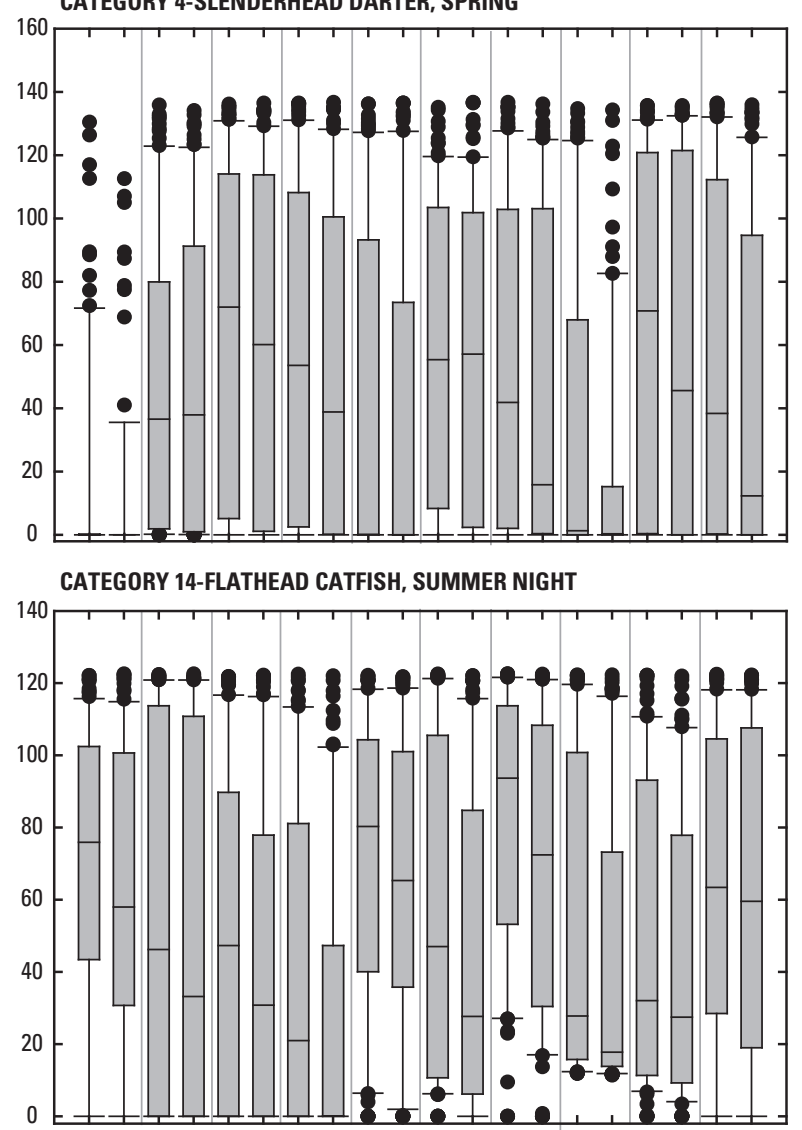

CATEGORY 19-STONECAT, SUMMER NIGHT

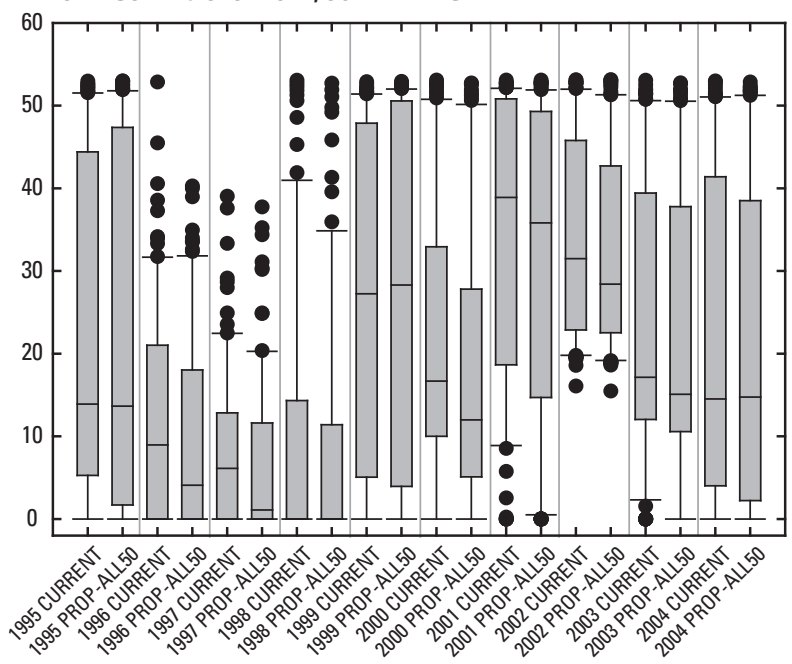

YEAR AND MODEL SCENARIO

Figure 45. Comparison of distributions of daily fish habitat for Current simulated and Prop-all50 streamflow scenarios, by year and select species/life stage categories, at the Marmaton River near the Kansas-Missouri state line, Missouri (RCHRES 6), water years 1995 through 2004. 

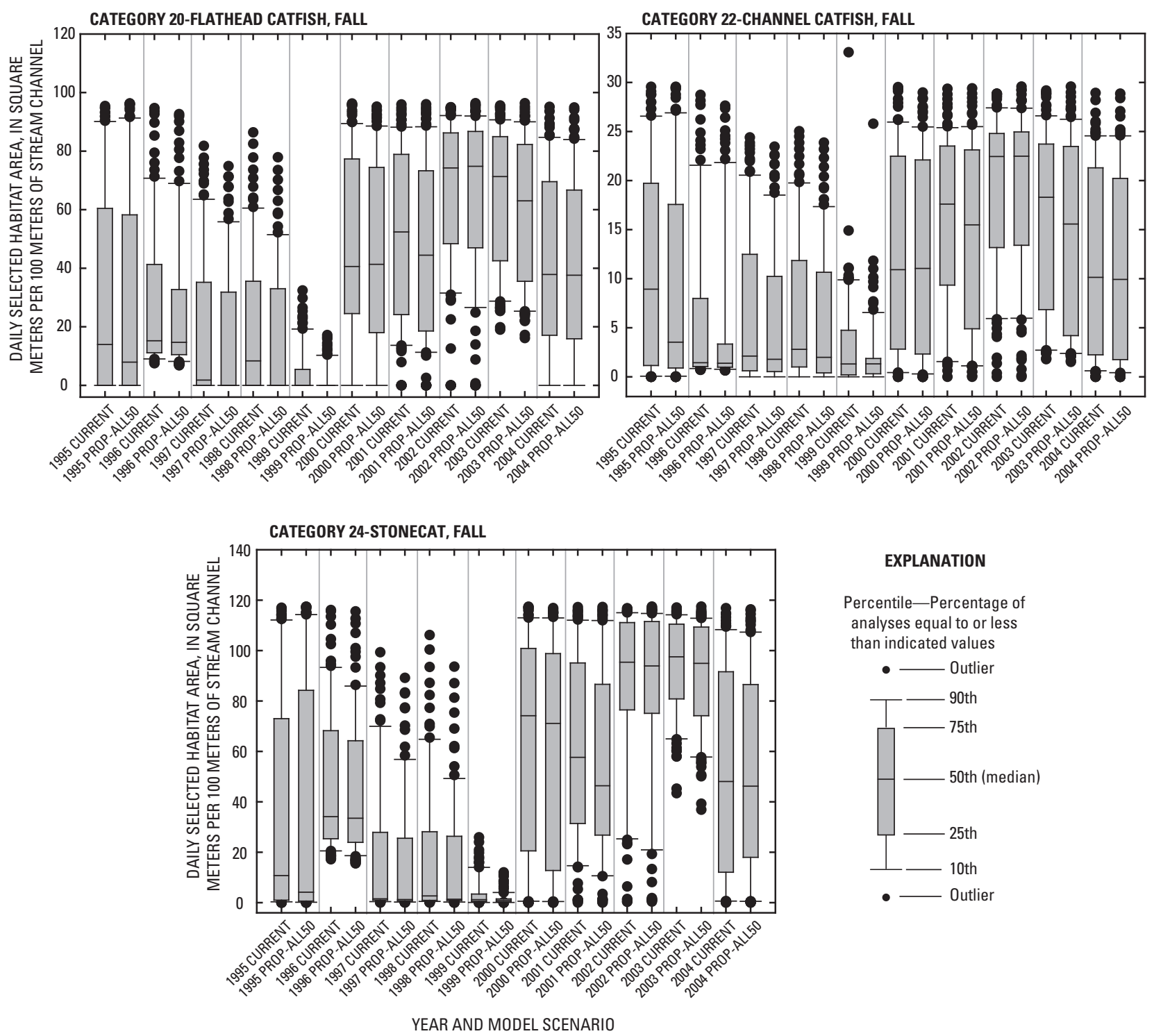

EXPLANATION

Percentile-Percentage of
analyses equal to or less

analyses equal to or less

- Outlier

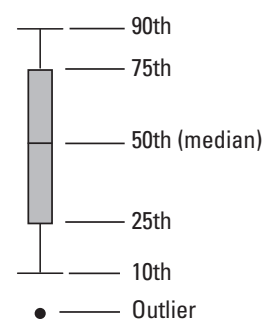

Figure 45. Comparison of distributions of daily fish habitat for Current simulated and Prop-all50 streamflow scenarios, by year and select species/life stage categories, at the Marmaton River near the Kansas-Missouri state line, Missouri (RCHRES 6), water years 1995 through 2004.-Continued 


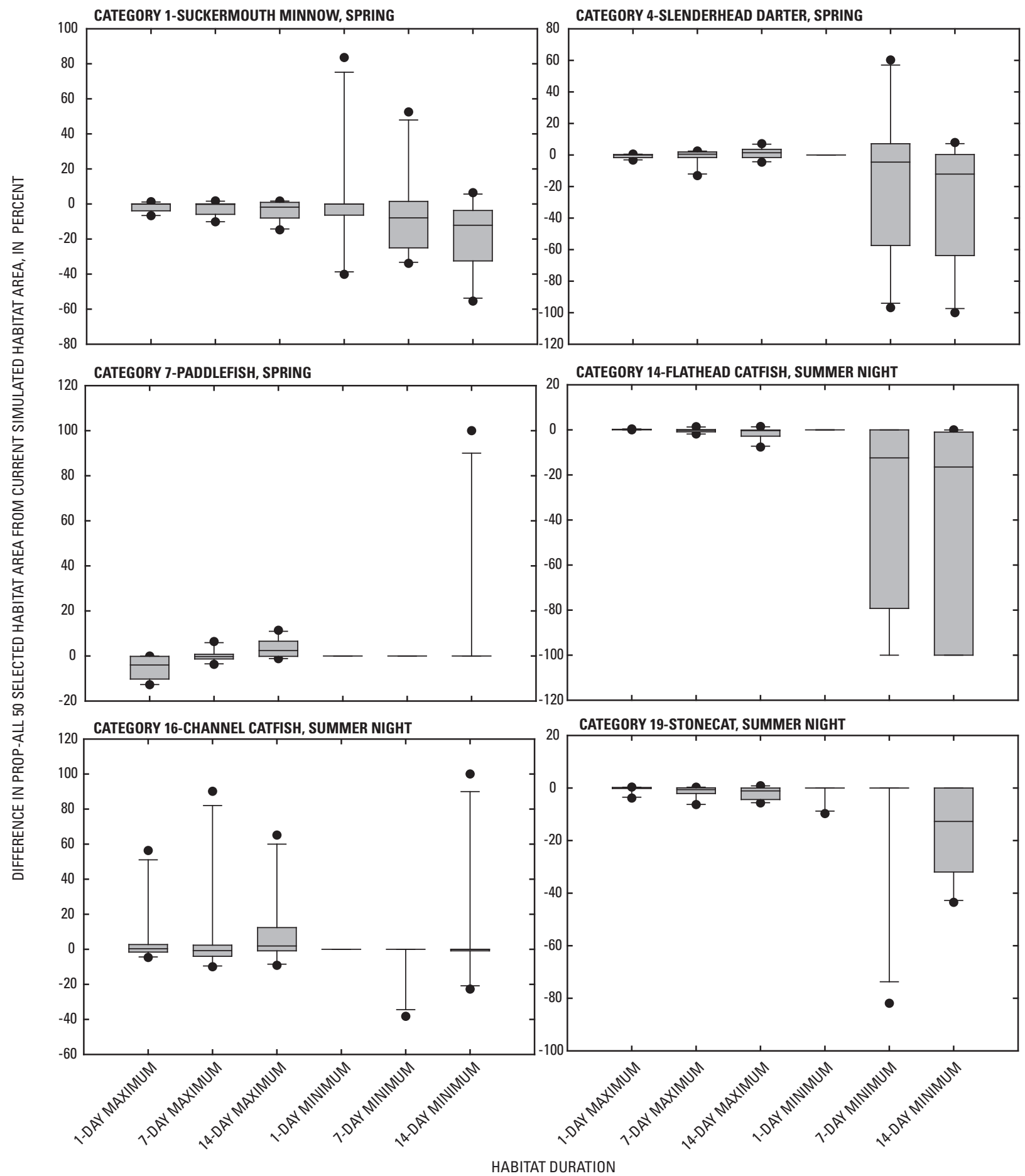

Figure 46. Distribution of percent differences between Prop-all50 and Current simulated fish habitat for 1-, 7-, and 14-day maximum and minimum durations, by selected species/life stage categories, at the Marmaton River near the KansasMissouri state line, Missouri (RCHRES 6), water years 1995 through 2004. 

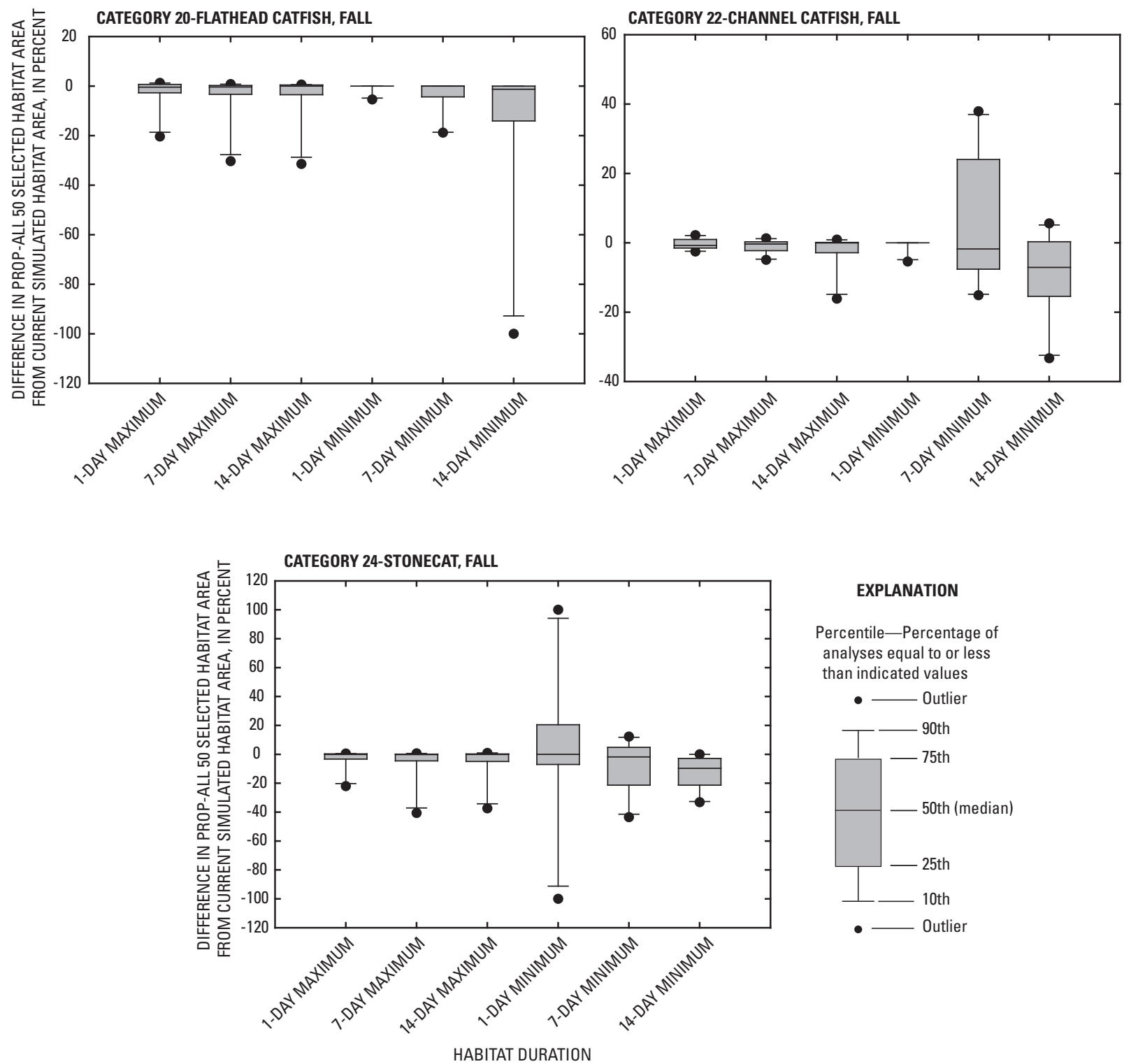

EXPLANATION

Percentile-Percentage of

analyses equal to or less

than indicated values

- - Outlier

T—

$T$ - 75 th

— 50th (median)

- 25th

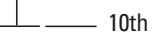

- - Outlier

Figure 46. Distribution of percent differences between Prop-all50 and Current simulated fish habitat for 1-, 7-, and 14-day maximum and minimum durations, by selected species/life stage categories, at the Marmaton River near the KansasMissouri state line, Missouri (RCHRES 6), water years 1995 through 2004.-Continued 
CATEGORY 1-SUCKERMOUTH MINNOW, SPRING
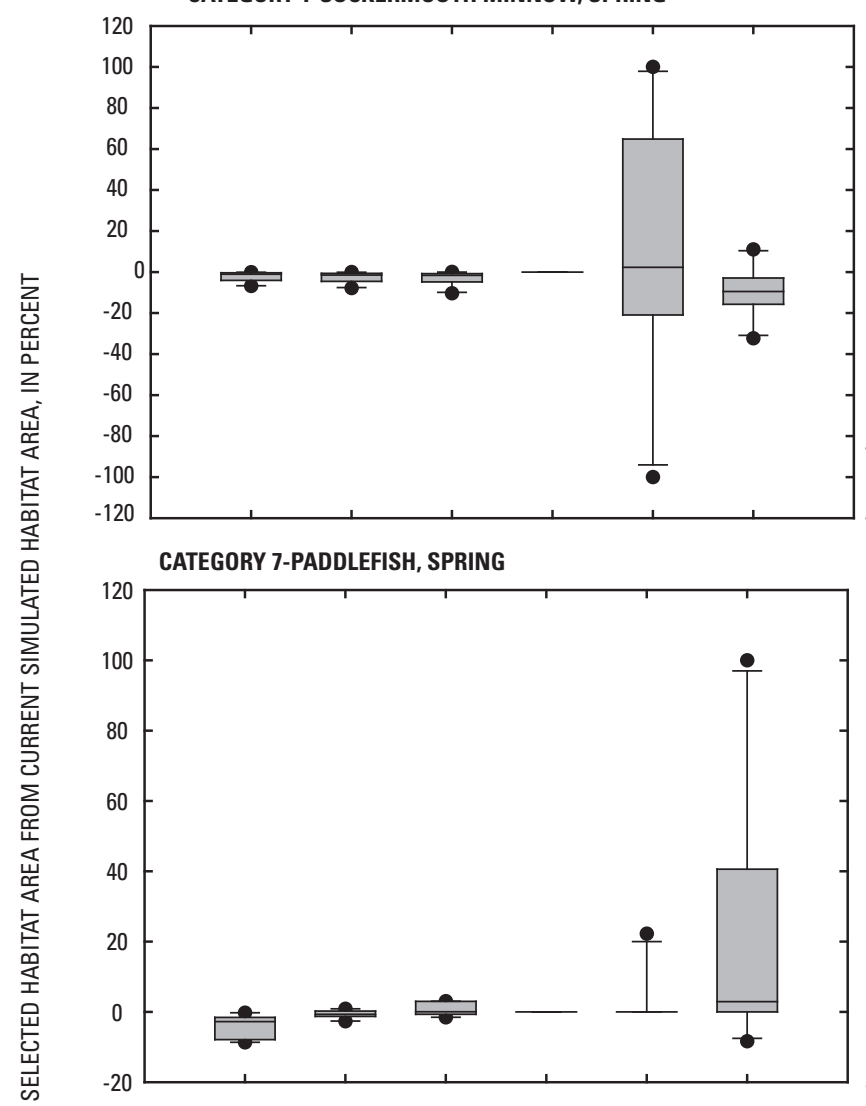

CATEGORY 16-CHANNEL CATFISH, SUMMER NIGHT

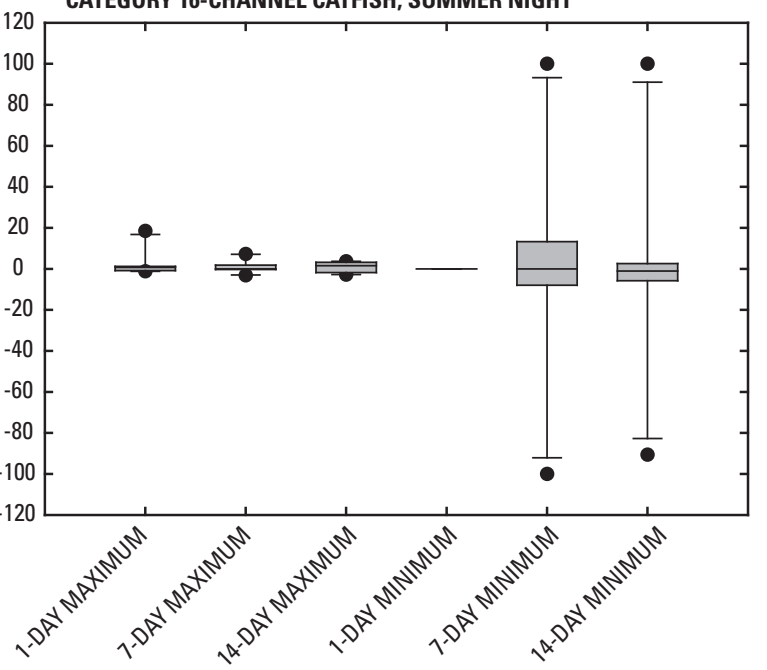

CATEGORY 4-SLENDERHEAD DARTER, SPRING
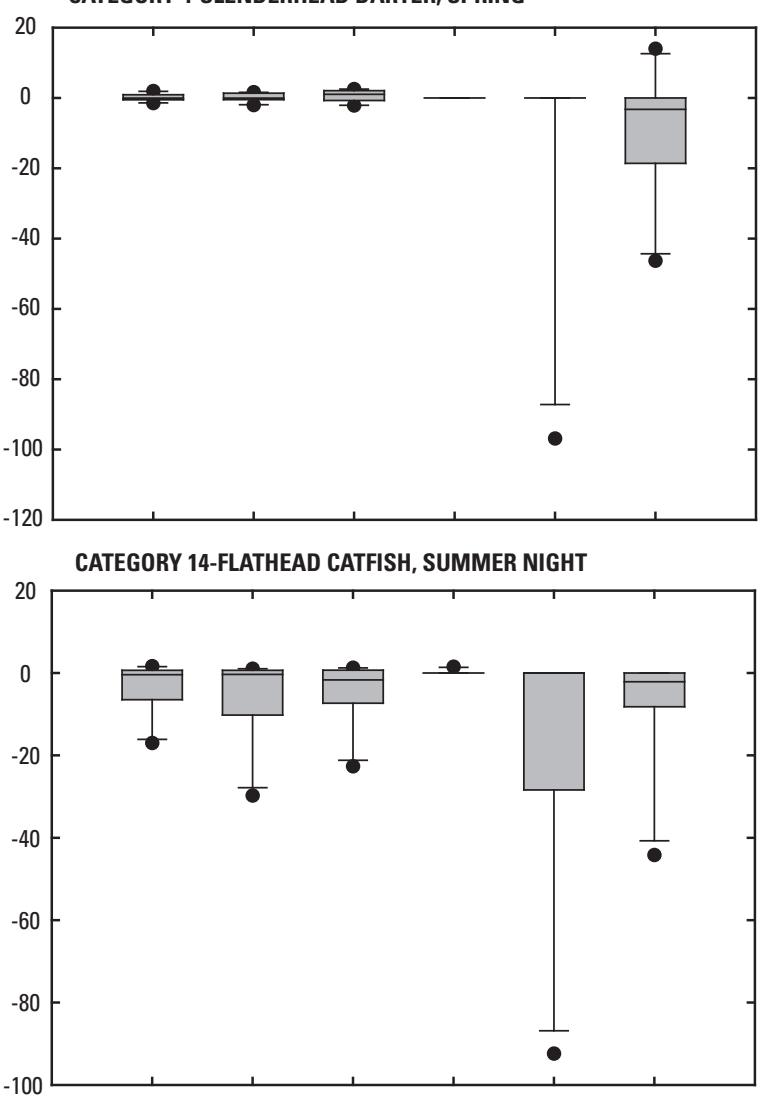

CATEGORY 19-STONECAT, SUMMER NIGHT

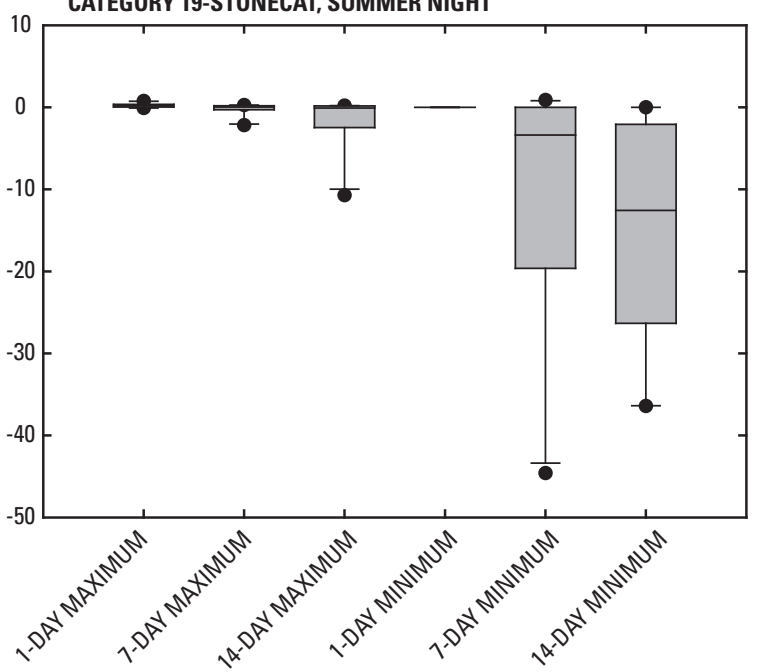

HABITAT DURATION

Figure 47. Distribution of percent differences between Prop-all50 and Current simulated fish habitat for 1-, 7-, and 14-day maximum and minimum durations, by selected species/life stage categories, at the Marmaton River RCHRES 11, water years 1995 through 2004. 

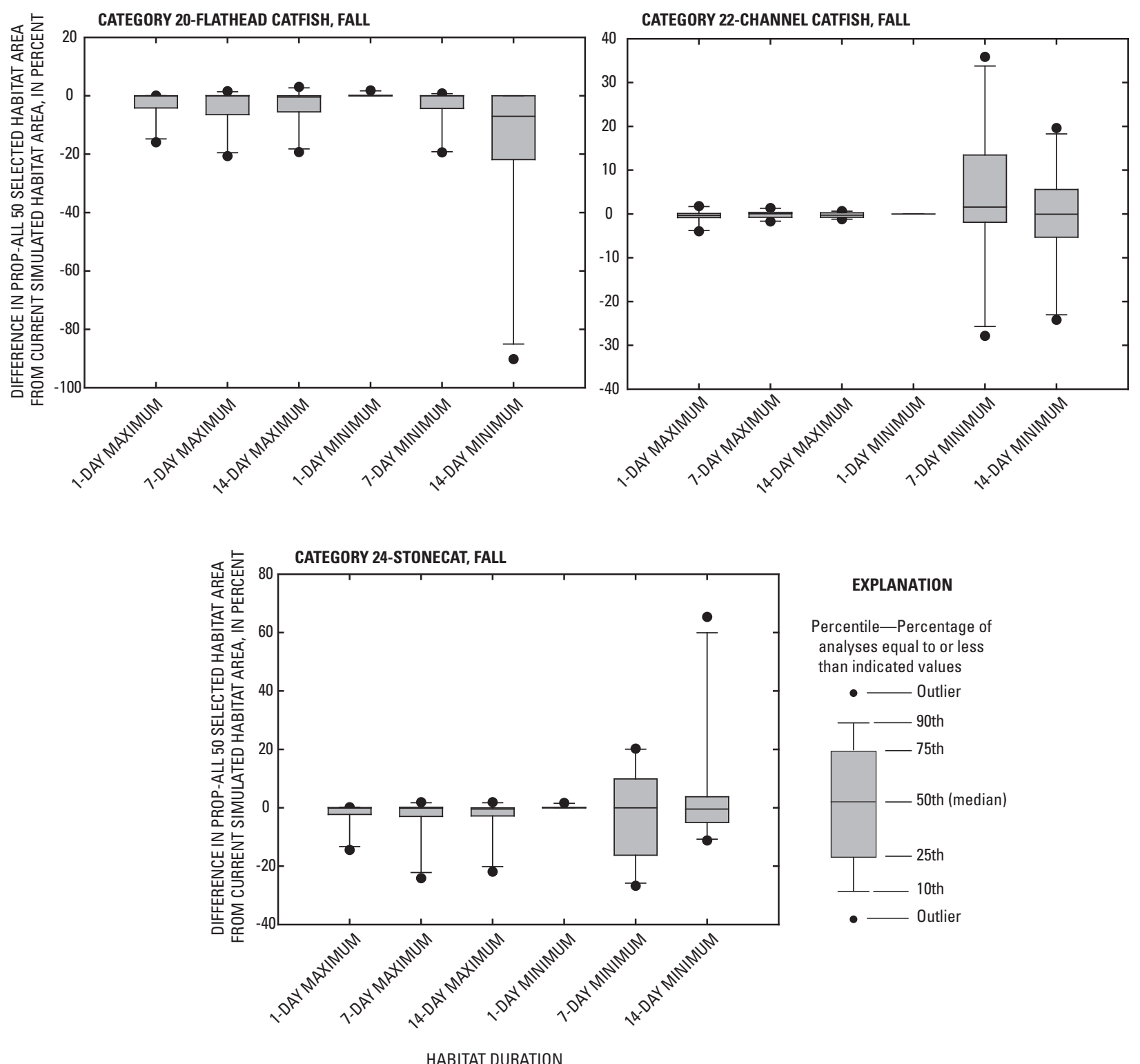

Figure 47. Distribution of percent differences between Prop-all50 and Current simulated fish habitat for 1-, 7-, and 14-day maximum and minimum durations, by selected species/life stage categories, at the Marmaton River RCHRES 11, water years 1995 through 2004.-Continued 
ences in total runoff between pre-settlement and the current and proposed scenarios. Evaporative water losses increased with the addition of impoundments, and while these increases did not have a substantial effect on the total runoff they could have an effect on flows during dry periods. Greater detention associated with impoundments resulted in longer hydrograph recessions and lowered peak flows. Outflows for a single, isolated impoundment indicated that low and high flows may be affected by design characteristics. The $10^{\text {th }}$-percentile design scenario, representative of smaller outflow structures and longer detention time, resulted in the longest hydrograph recessions and lowest peak flows. The $90^{\text {th }}$-percentile design scenario, representative of larger possible outflow structures and shorter detention time, resulted in the fastest hydrograph recessions and highest peak flows of the three proposed impoundment design scenarios.

Differences in simulated monthly minimum 1-, 3-. 7-, and 30-day low flows from observed flows at the Marais des Cygnes River near the Kansas-Missouri state line, Kansas, for the 10-year simulation period, indicated that the proposed design scenario with the greatest detention characteristics resulted in the least decreases in low flows relative to observed flows, whereas the proposed scenario with the least detention characteristics resulted in the greatest occurrence of low flow declines. The longest period of extended declines (5 months) occurred in the summer months of 2001 and 2002. October had the greatest magnitude of declines in proposed monthly minimum 1-, 3-, 7-, and 30-day low flows compared with observed flows. The greatest declines for proposed conditions were for the lowest 10 percentile of observed flows and during the driest years (2000, 2001 water years). The most apparent difference in minimum flows for the simulation scenarios at the Marais des Cygnes River near the Kansas-Missouri state line, Kansas, were between observed and pre-settlement scenarios.

There were no additional impoundments proposed for the Little Osage River Basin and, therefore, proposed scenarios were not simulated for this basin, but the pre-settlement low flows generally were greater than observed flows at the Little Osage River near Fulton, Kansas. Pre-settlement low flows seemed to be particularly better sustained than observed flows during dry years (2000-2003 water years), and with increasing flow duration period (from 1-day to 30-day periods).

Low flows in the Marmaton River Basin generally were lower for the current simulated or observed scenarios than any other simulated conditions. In a small headwater basin in the upper Marmaton River Basin, simulated declines in minimum flows were small [generally less than 6 cubic feet per second $\left(\mathrm{ft}^{3} / \mathrm{s}\right)$ ] and less than $1 \mathrm{ft}^{3} / \mathrm{s}$ for 1 - and 3-day scenarios), but resulted in 10 to 18 additional zero flow days for the proposed scenarios relative to current simulated conditions. Declines occurred primarily during the summer months. Simulated presettlement minimum flows generally were greater than current simulated flows for all flow duration periods, with maximum monthly differences generally less than $10 \mathrm{ft}^{3} / \mathrm{s}$. Differences between simulated and observed minimum monthly flows were similar at the Marmaton River near Marmaton, Kansas, site to those at the headwater site. Reductions in minimum monthly flows as a result of additional impoundments generally were less than $5 \mathrm{ft}^{3} / \mathrm{s}$ and resulted in 6 additional zero flow days. Simulated pre-settlement monthly minimum flows generally were greater than observed flows, with maximum monthly reductions in minimum flows between pre-settlement and observed flows of 36 to $71 \mathrm{ft}^{3} / \mathrm{s}$. Similar to the headwater and Marmaton, Kansas, locations, the reductions in flows at the Marmaton River near the Kansas-Missouri state line, Missouri, as a result of proposed impoundments, were most frequent for the scenario representing the least impoundment detention and generally occurred in the summer months. The greatest declines between proposed and current flows generally occurred in the lower 50 percentile of current simulated flows and during the drier water years of 2001-2003. Proposed conditions resulted in declines in the $0-10$ percentile flow values for the 1-, 3-, and 7-day duration periods. Presettlement minimum flows generally were greater than current simulated scenario flows for all flow duration periods, with maximum declines in monthly low flows of 150 to $165 \mathrm{ft}^{3} / \mathrm{s}$ between pre-settlement and current scenarios.

Simulated proposed monthly high flows were reduced as a result of the addition of impoundments in all basins and at all reporting locations. Observed 1-day, monthly maximum streamflows at the Marais des Cygnes near the KansasMissouri state line, Kansas, were, on average, 5 to $17 \mathrm{ft}^{3} / \mathrm{s}$ greater than proposed maximum monthly flows. Pre-settlement 1-day monthly maximum flows were, on average, 540 to $776 \mathrm{ft}^{3} / \mathrm{s}$ greater than observed 1-day monthly maximum flows, indicating that, similar to low flows, the characteristics of high flows in this basin also have undergone greater changes between pre-settlement to current conditions than would be expected from current to proposed conditions. These changes between pre-settlement and current conditions in this basin were the result of several large impoundments with managed detention and outflow characteristics. Observed monthly maximum flows at the Little Osage River near Fulton, Kansas, were similar to pre-settlement monthly maximums. The observed or current simulated maximum monthly flows were, on average, greater than historical or proposed flow conditions in the Marmaton River Basin. Current monthly maximum flows in the Marmaton River near the Kansas-Missouri state line, Missouri, were 46 to $300 \mathrm{ft}^{3} / \mathrm{s}$ greater than proposed monthly maximum flows, depending on impoundment outflow design. The simulations with the greatest detention capabilities of impoundments resulted in the largest differences in high flows. Observed 1-day maximum monthly flows at this site were, on average, $109 \mathrm{ft}^{3} / \mathrm{s}$ greater than pre-settlement scenario flows.

An ecological consequence of a reduction in streamflow magnitude is a decrease in flood frequency and flood-plain inundation. The flood frequency for the Marais des Cygnes River near the Kansas-Missouri state line, Kansas, was substantially decreased between pre-settlement and observed conditions, but observed and proposed conditions were similar. This decrease in flooding can be attributed to the substantial 
amount of current, controlled regulation in the Marais des Cygnes River Basin. There were no differences between presettlement and observed flood frequency at the Little Osage River near Fulton, Kansas. Flood frequency generally was greatest for the current simulated or observed scenarios in the Marmaton River Basin and least for the proposed conditions. The effects of regulation on flood frequency decreased downstream from the Kansas-Missouri state line. The flood frequency of the proposed scenarios were 54 to 60 percent less, depending on outflow and detention characteristics, than current simulated conditions at the Marmaton River near the Kansas-Missouri state line, Missouri. The reduction in flood frequency was greatest in the scenario incorporating the greatest estimated impoundment detention characteristics. At a downstream site, the total reduction in flood frequency from current to Prop-all conditions was less (21 to 28 percent) than the state line site. The downstream site is below a primary Marmaton River tributary with little local regulation and, therefore, the effects of proposed upstream regulation were reduced.

The simulated effects of regulation on large flood durations varied between model basins and with degree of regulation. Increased regulation increased the total hydrograph duration (duration from pre-event base flow to post-peak base flow) of floods. The average duration of large flood hydrographs was similar for observed and proposed scenarios at the Marais des Cygnes River near Kansas-Missouri state line, Kansas. Pre-settlement scenario flood hydrograph durations were, on average, about 80 percent less than observed. The average large flood hydrograph duration at the Little Osage River near Fulton, Kansas, for the pre-settlement scenario, using assumed increased infiltration estimates under historical land cover, was about 120 percent greater than observed conditions. At the Marmaton River headwater and Marmaton River near Marmaton, Kansas, locations, the average large flood hydrograph durations under proposed and pre-settlement scenarios were about 50 percent greater than observed and current simulated scenarios. At the Marmaton River near the Kansas-Missouri state line, Missouri, the average proposed scenario total flood hydrograph durations were 2 to 70 percent greater than current simulated conditions depending on scenario, whereas flood hydrograph durations were similar under pre-settlement and current simulated conditions.

Although the total hydrograph duration increased with regulation, the actual duration of streamflows above estimated flood levels (flooding period) decreased with proposed regulation in all model basins. The flooding period at the Marais des Cygnes River near the Kansas-Missouri state line, Kansas, decreased about 2 to 7 percent from observed to proposed conditions. The largest difference in flooding periods at this Marais des Cygnes River site occurred between pre-settlement and observed scenarios in which pre-settlement average flooding periods were 200 percent greater than observed conditions. Pre-settlement flooding periods in the Little Osage River near Fulton, Kansas, were similar (within 4 percent) to observed conditions. At the Marmaton River near the Kansas-Missouri state line, Missouri, the average flooding period under proposed scenarios showed a 60 percent reduction from current simulated conditions.

The timing of floods during the 10-year simulation period in the model basins was not substantially affected by regulation, although the timing of low flow extremes was altered in some basins. The timing of Little Osage River extreme low flows were similar between pre-settlement and observed flow scenarios, but the pre-settlement large flood timing was in June rather than September, as for observed flows. At the Marmaton River near Marmaton, Kansas, the timing of peak flows was similar between scenarios, but the timing of extreme low flows was August for pre-settlement conditions and November for observed and most proposed scenarios. The timing of low and high flows was similar under all scenarios at the Marmaton River near the Kansas-Missouri state line, Missouri.

The ecological consequences of altered conditions also were assessed through changes in in-stream habitat. Comparisons of 10-year daily habitat area distributions for nine selected fish species/life stage categories under the varying streamflow simulation scenarios indicated that the effect of flow alteration on fish habitat varied by basin, scenario, time distribution, and fish species/life stage category. Of particular concern in comparing differences in habitat by scenario were any possible declines in the minimum habitat availability that could lead to greater limiting conditions or "bottlenecks" in fish habitat availability and possible habitat declines of extended (7-14 days) durations. Minimum annual 1-, 7-, or 14-day habitat availability for the prop-all50 ${ }_{\text {adj }}$ simulation declined at each of three Marais des Cygnes River sites by more than 10 percent compared with observed conditions for 1 or more years for each of the nine seasonal fish habitat categories, indicating that habitat bottlenecks may be greater during proposed conditions for some categories under some seasons. Declines in minimum habitat availability were at or near 100 percent for 1 or more years for summer flathead catfish, fall flathead catfish, fall channel catfish, and fall stonecat habitat categories at one Marais des Cygnes River location and for summer flathead catfish, summer channel catfish, and summary stonecat at another Marais des Cygnes River location. This indicates that habitat for these categories may be eliminated for 1 to 14 days during some period of some years under proposed conditions. Habitat generally declined at the Marmaton River near the Kansas-Missouri state line, Missouri, under the proposed scenario compared with current conditions. Declines in annual 1-, 7-, or 14-day minimum habitat were greater than 10 percent for 1 or more years for all categories at both Marmaton River reporting locations, except for spring paddlefish habitat, which generally remained unchanged between current and proposed scenarios at one location. Declines in 1-, 7-, or 14-day proposed minimum habitat availability were at or near 100 percent for 1 or more years for slenderhead darter, summer flathead catfish, fall channel catfish, and fall stonecat habitat categories at one Marmaton River location and for spring suckermouth minnow, spring 
slenderhead darter, summer channel catfish, summer stonecat, and fall flathead catfish habitat at another.

The cumulative effects of impoundments and land-cover changes were determined to substantially alter streamflows in the upper Osage River Basin in simulations spanning pre-settlement to proposed future conditions. The impoundments in these basins were designed, located, and constructed to address local considerations and the hydrologic simulations provided a means of quantifying the cumulative effects of these local projects. The degree of streamflow alteration varied between major subbasins. Streamflows in the Marais des Cygnes River Basin were altered between pre-settlement and current conditions, primarily by major impoundments, with smaller changes expected with proposed regulation. Streamflows in the Little Osage River Basin were relatively unchanged between pre-settlement and current conditions with land-cover changes (primarily the conversion of native prairies to cultivated land) affecting flows more than the few current impoundments in this basin. The current peak flows in the Marmaton River Basin were higher than pre-settlement or proposed scenario peak flows. Of the three major subbasins, this basin is likely to be the most affected by proposed impoundments.

Simulations for differing impoundment outflow designs indicated that outflow design considerations can make a substantial difference in low and high flows, particularly in the Marmaton River Basin. The primary effects of impoundments on flows were to detain event peaks and slowly release detained flows, thereby extending recessions, but the retention of flow also can lead to additional zero flow days compared with current conditions. Unknown potential changes in water-use conditions also may be a consideration under future streamflow conditions, particularly during extreme low-flow conditions. Proposed conditions will result in alterations in streamflows in the upper Osage River Basin; therefore, the ecological effects of these flow alterations also were of interest. Streamflow alterations resulted in quantified changes in in-stream fish habitat with the potential of magnifying habitat bottlenecks for some species, locations, and years providing managers with another means of assessing the effects of proposed alterations. Whereas flood storage and peak flow reduction is a primary purpose for the construction of many of the impoundments, the ecological consequences of reduced flood frequency and magnitude under proposed conditions on the maintenance and function of riparian systems, particularly in the Marmaton River Basin, are unknown.

\section{References Cited}

Anderson, E.A., 2002, Calibration of conceptual hydrologic models for use in river forecasting, Available at http://www. nws.noaa.gov/oh/hrl/calb/calibration1102/main.htm.
Berris, S.N., Hess, G.W., and Bohman, LR., 2001, River and reservoir operations model, Truckee River, California and Nevada, 1998: U.S. Geological Survey Water-Resources Investigations Report 01-4017, 138 p.

Bevans, H.E., Skelton, John, Kenny, J.F., and Davis, J.V., 1984, Hydrology of Area 39, Western Region Interior Coas1 Province Kansas and Missouri: U.S. Geological Survey Open-File Report 83-851, 83 p.

Bicknell, B.R., Imhoff, J.C., Kittle, J.L., Jr., Jobes, T.H. and Donigian, A.S., Jr., 2004, Hydrological Simulation Program-FORTRAN, user's manual version 12.1: Athens, Ga., U.S. Environmental Protection Agency Research Laboratory, $885 \mathrm{p}$.

Coon, W.F., and Johnson, M.S., 2005, Effects of land-use changes and stormflow-detention basins on flooding and nonpoint-source pollution, in Irondequiot Creek Basin, Monroe and Ontario Counties, New York-Application of a Precipitation-Runoff Model: U.S. Geological Survey Scientific Investigations Report 2005-5070, 67 p.

Dahl, T.E., 1990, Wetland losses in the United States 1780's to 1980's: Washington D.C.,U.S. Fish and Wildlife Service, $13 \mathrm{p}$.

Dent, R.J., Jr., Fantz, D.K., Heatherly, W.G., and Yasger, P.A., 1997, West Osage River Basin Inventory and Management Plan: Missouri Department of Conservation, accessed on January 30, 2004, at http://mdc.mo.gov/fish/watershed/ wosage/contents/310cotxt.htm.

Dinicola, R.S., 1990, Characterization and simulation of rainfall-runoff relations for headwater basins in western King and Snohomish Counties, Washington: U.S. Geological Survey Water-Resources Investigations Report 89-4052, $52 \mathrm{p}$.

Dinicola, R.S., 2001, Validation of a numerical modeling method for simulating rainfall-runoff relations for headwater basins in western King and Snohomish Counties, Washington: U.S. Geological Survey Water-Supply Paper 2495, $162 \mathrm{p}$.

Donigian, A.S., Jr., 2002, Watershed model calibration and validation-the HSPF experience: Water Environment Federation National TMDL Science and Policy 2002, Phoenix, Ariz., Specialty Conference Proceedings, 30 p., accessed June 7, 2005, at http://www.aquaterra.com/publications. htm.

Donigian, A.S., Jr., and Imhoff, J.C., 2006, History and evolution of watershed modeling derived from the Stanford Watershed Model, Chapter 2, in Singh, V.J., and Frevert, D.K., eds., Watershed Models. CRC Press, Boca Raton, Fla., p. 21-45. 
Duncker, J.J., and Melching, C.S., 1998, Regional rainfallrunoff relations for simulation of streamflow for watersheds in DuPage County, Illinois: U.S. Geological Survey WaterResources Investigations Report 98-4035, 80 p.

Duncker, J.J., Vail, T.J., and Melching, C.S., 1995, Regional rainfall-runoff relations for simulation of streamflow for watersheds in Lake County, Illinois: U.S. Geological Survey Water-Resources Investigations Report 95-4023, 71 p.

Environmental Systems Research Institute, 2002, ArcView, version 3.3: Redlands, Calif., Environmental Systems Research Institute.

Fuentes, J.P., Flury, M., and Bezdicek, D.F., 2004, Hydraulic properties in a silt loam soil under natural prairie, conventional till, and no till: Soil Science Society of America Journal, v. 68, p. 1,679-1,688.

Groisman, P.Ya., Peck, E.L., and Quayle, R.G., 1999, Intercomparison of recording and standard nonrecording U.S. gauges: Journal of Atmospheric and Oceanic Technology, v. 16, p. 602-609.

Gutiérrez-Magness, A.L., and McCuen, R.H., 2004, Accuracy evaluation of rainfall disaggregation methods: Journal of Hydrologic Engineering, v. 9, no. 2, p. 71-78.

Gutiérrez-Magness, A.L., 2005, A strategy for calibrating the HSPF model: University of Maryland, Department of Civil and Environmental Engineering, Ph.D. Dissertation, College Park, Md., 269 p.

Hall, A.P., and Orazem, P.F., 2005, Economic trends along the Kansas-Missouri border, 1969-2003: Kansas, Inc. Research Report, Topeka, Kans., 18 p.

Hahn, J.T., and Spencer, J.S., Jr., 1991, Timber resources of Missouri, Statistical Report 1989: U.S. Department of Agriculture Forest Service, North Carolina Forest Experiment Station, Resource Bulletin NC-199, St. Paul, Minn, 123 p.

Hamon, W.R., 1961, Estimating potential evapotranspiration: Journal of the Hydraulics Division, Proceedings of the American Society of Civil Engineers, v. 87, p. 107-120.

Hanson, C.L., Johnson, G.L., McFarland, M.J., Gebhardt, K., and Smith, J.A., 1996, Chapter 2-Precipitation, p. 5-74 in Hydrology Handbook: American Society of Civil Engineers, Reston, Va., 784 p.

Heimann, D.C., and Mettler-Cherry, P.A., 2004, Hydrologic, soil, and vegetation gradients in remnant and constructed riparian wetlands in west-central Missouri, 2001-04: U.S. Geological Survey Scientific Investigations Report 2004-5216, 160 p.
Heimann, D.C., Richards, J.M., Brewer, S.K., and Norman, R.D., 2005, Quantification of fish habitat in selected reaches of the Marmaton and Marais des Cygnes Rivers, Missouri: U.S. Geological Survey Scientific Investigations Report 2005-5180, 58 p.

Helsel, D.R., and Hirsch, R.M., 1992, Statistical methods in water resources: New York, Elsevier Science Publishing Compay, $522 \mathrm{p}$.

High Plains Regional Climate Center, 2007, accessed February 6, 2007, at http://www.hprcc.unl.edu/wrcc/states/mo.html.

Hulsing, H., 1967, Measurement of peak discharge at dams by indirect methods: U.S. Geological Survey Techniques of Water-Resources Investigations, Book 3, Chapter A5, 29 p.

Jones, P.M., and Winterstein, T.A., 2000, Characterization of rainfall-runoff response and estimation of the effect of wetland restoration on runoff, Heron Lake Basin, Southwestern Minnesota, 1991-97: U.S. Geological Survey WaterResources Investigations Report 00-4095, 48 p.

Kansas Geological Survey, 1997, Physiographic map of Kansas, accessed June 15, 2006, at http://www.kgs.ku.edu Physio/physio.htm.

Kansas Water Office, 2004, Marais des Cygnes Basin Secion, accessed on February 23, 2005, at http://www.kwo.org KWP/MDC_BasinPlan_Supp_Assessment.pd].

Küchler, A.W., 1974, A new vegetation map of Kansas: Ecology, v. 55, no. 3 p. 586-604 and 1 p. map supplement "Potential Natural Vegetation of Kansas".

Laroche, Anne-Marie, Gallichand, J., Lagacé, R., and Pesant, A., 1996, Simulating atrazine transport with HSPF in an agricultural watershed: Journal of Environmental Engineering, v. 122, no. 7, p. 622-630.

Legates, D.R., and McCabe, G.L., Jr., 1999, Evaluating the use of "Goodness of Fit" measures in hydrologic and hydroclimatic model validation: Water Resources Research, v. 35, no. 1 p. 233-241.

Leopold, L.B., 1994, A view of the river: Harvard University Press. Cambridge, Mass., 298 p.

Love, J.T., and Donigian, A.S., Jr., 2004, Deriving model input for a lumped parameter watershed model: AWRA 2004 Spring Specialty conference-GIS and Water Resources III, May 17-19, 2004, Nashville, Tenn.: American Water Resources Association, Middleburg, Va.

Lumb, A.M., McCammon, R.B., and Kittle, J.L., Jr., 1994, Users manual for the expert system (HSPEXP) for calibration of the Hydrologic Simulation Program-FORTRAN: U.S. Geological Survey Water-Resources Investigations Report 94-4168, 102 p. 
McDermott, J.F., 1940, Tixier's travels on the Osage Prairies, University of Oklahoma Press, Norman, Okla., 309 p.

Missouri Department of Natural Resources, 2000, Census of Missouri public water supply systems 2000: Division of Environmental Quality, Drinking Water Program, Jefferson City, Mo.

Nash, J.E., and Sutcliffe, J.V., 1970, River flow forecasting through conceptual models, Part-I, A discussion of principles: Journal of Hydrology, v. 10, p. 282-290.

National Weather Service Office of Hydrologic Development, 1999, Interactive double mass analysis user's manual, Version 1.2 NOAA Headquarters, Silver Spring, Maryland, accessed November 15, 2005, at http://www.nws.noaa.gov oh/hrl/nwsrfs/users_manual/htm/formats.php.

National Weather Service Office of Hydrologic Development, 2004, NWSRFS User's Manual. NOAA Headquarters, Silver Spring, Maryland, accessed November 15, 2005, at http://www.nws.noaa.gov/oh/hrl/nwsrfs/users_manual/htm formats.php

Nelson, P.W., 1985, The terrestrial natural communities of Missouri: Jefferson City, Mo., Missouri Natural Areas Committee, $197 \mathrm{p}$.

NOHRCS, 2005, Integrated Hydrologic Automated Basin Boundary System (IHABBS) accessed November 15, 2005, at http://www.nohrsc.nws.gov/technology/gis/ihabbs_ overview.html.

Pan, J., Bonnin, G.M., Motl, R.M., and Friedeman, H., 1998, Recent developments in the data analysis quality control and data browsing: Phoenix, Ariz., National Weather Service Office of Hydrology, 78th Annual AMS Meeting, January, 1998, accessed January 10, 2006, at: http://www. nws.noaa.gov/oh/hrl/papers/ams/ams98-4.htm.

Poff, N.L., Allan, J.D., Bain, M.B., Karr, J.R, Prestegaard, K.L., Richter, B.C., Sparks, R.E., and Stromberg, J.C., 1997, The natural flow regime: Bioscience, v. 47, p. 769-784.

Regan, R.S., and Schaffranek, R.W., 1985, A computer program for analyzing channel geometry: U.S. Geological Survey Water-Resources Investigations Report 85-4335, 40 p.

Renwick, W.H., Smith, S.V., Bartley, J.D., and Buddemeier, R.W., 2005, The role of impoundments in the sediment budget of the conterminous United States: Geomorphology, v. 71, p. 99-111.

Schroeder, W.A., 1983, Presettlement prairie of Missouri: Missouri Department of Conservation, Jefferson City, Missouri, $38 \mathrm{p}$.
Skelton, John, 1976, Missouri stream and sprinflow characteristics: Rolla, Missouri Department of Natural Resources, Division of Geology and Land Survey, Water Resources Report Number 32, $71 \mathrm{p}$.

Smith, S.V., Renwick, W.H., Bartley, J.D., and Buddemeyer, R.W., 2002, Distribution and significance of small, artificial water bodies across the United States landscape: The Science of the Total Environment, v. 299, p. 21-36.

The Nature Conservancy, 2005, Indicators of hydrologic alteration, version 7, User's Manual, accessed on February 10, 2005, at http://www.freshwaters.org/tools/.

U.S. Army Corps of Engineers, 2005, National Inventory of Dams, accessed November 29, 2005, at http://crunch.tec. army.mil/nid/webpages/nid.cfm.

U.S. Census Bureau, 2006, 2000 Census Data, accessed February 2, 2006, at http://quickfacts.census.gov/qfdd

U.S. Department of Agriculture, 1970, South Grand-Osage River Basin in Missouri: Soil Conservation Service, Columbia, Mo., 160 p.

U.S. Department of Agriculture, 1981, Land resource regions and major land resource areas of the United States: Soil Conservation Service Agruculture Handbook 296, 156 p.

U.S. Department of Agriculture, 1991, State Soil Geographic (STATSGO) Data Base Data Use Information: Natural Resource Conservation Service, Miscellaneous Publication Number 1492, 110 p.

U.S. Environmental Protection Agency, 2000, BASINS Technical Note 6-Estimating hydrology and hydraulic parameters for HSPF: U.S. Environmental Protection Agency, EPA-823-R00-012, 32 p.

U.S. Environmental Protection Agency, 2005a, BASINS: Better assessment science integrating point and non-point sources, version 3.1 accessed November 1, 2005, at http:/h www.epa.gov/OST/BASINS

U.S. Environmental Protection Agency, 2005b, WDMUtil A tool for managing watershed modeling time series data User's manual, accessed November 1, 2005, at $h t t p: / / w w w$. epa.gov/waterscience/basins/bsnsdocs.html\#pload.

U.S. Geological Survey, 2005a, National land cover dataset, accessed November 29, 2005, at http:///andcover.usgs.gov hatlandcover.asp.

U.S. Geological Survey, 2005b, National elevation dataset, accessed November 29, 2005, at http://gisdata.usgs.net nedt.

U.S. Geological Survey, 2005c, National hydrography dataset-high resolution, accessed November 29, 2005, at http://nhd.usgs.gov. 
U.S. Geological Survey, 2005d, CGAP-GenFTABLE, HspfEXP, GenScn http://water.usgs.gov/software/surface_water. htm

U.S. Geological Survey, 2007, USGS Surface-water data for Missouri, accessed February 16, 2007, at http://waterdata. usgs.gov/mo/nwis/sw.

Ward, A.D., and Elliot, W.J., 1995, Environmental hydrology: Lewis Publishers, Boca Raton, Fla., 496 p.

Zarriello, P.J., 1996, Simulated effects of a stormwater-detention basin on peak flows and water quality of East Branch Allen Creek, Monroe County, New York: U.S. Geological Survey Water-Resources Investigations Report 95-4157, $34 \mathrm{p}$.
Zarriello, P.J., and Sherwood, D.A., 1993, Effects of stormwater detention on the chemical quality of runoff from a small residential development, Monroe County, New York: U.S. Geological Survey Water-Resources Investigations Report 92-4003, $57 \mathrm{p}$.

Zarriello, P.J. and Ries, K.G. III, 2000, A precipitation-runoff model for analysis of the effects of water withdrawals on streamflow, Ipswich River basin, Massachusetts: U.S. Geological Survey Water-Resources Investigations Report 00-4029, $99 \mathrm{p}$.

Zarriello, P.J., and Bent, G.C., 2004, A precipitation-runoff model for the analysis of the effects of water withdrawals and land-use change on streamflow in the UsequepaugQueen River Basin, Rhode Island: U.S. Geological Survey Scientific Investigations Report 2004-5139, 75 p.

Publishing support provided by:

Rolla Publishing Service Center

For more information concerning this publication, contact:

Director, USGS Missouri Water Science Center

1400 Independence Road

Rolla, M0 65401

(573) 308-3667

Or visit the Missouri Water Science Center Web site at:

http://mo.water.usgs.gov 



$$
\frac{\|}{2}
$$

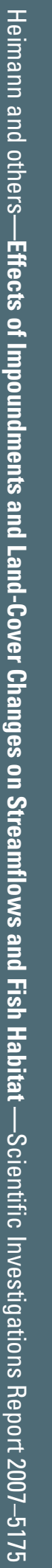

Printed on recycled paper 